\title{
Steeds mooier : over geschiedenis en zin van vooruitgangsideeën in de kunst
}

Citation for published version (APA):

Doorman, M. (1994). Steeds mooier : over geschiedenis en zin van vooruitgangsideeën in de kunst. [, Maastricht University]. Bert Bakker. https://doi.org/10.26481/dis.19941027md

Document status and date:

Published: 01/01/1994

DOI:

10.26481/dis.19941027md

Document Version:

Publisher's PDF, also known as Version of record

\section{Please check the document version of this publication:}

- A submitted manuscript is the version of the article upon submission and before peer-review. There can be important differences between the submitted version and the official published version of record.

People interested in the research are advised to contact the author for the final version of the publication, or visit the DOI to the publisher's website.

- The final author version and the galley proof are versions of the publication after peer review.

- The final published version features the final layout of the paper including the volume, issue and page numbers.

Link to publication

\footnotetext{
General rights rights.

- You may freely distribute the URL identifying the publication in the public portal. please follow below link for the End User Agreement:

www.umlib.nl/taverne-license

Take down policy

If you believe that this document breaches copyright please contact us at:

repository@maastrichtuniversity.nl

providing details and we will investigate your claim.
}

Copyright and moral rights for the publications made accessible in the public portal are retained by the authors and/or other copyright owners and it is a condition of accessing publications that users recognise and abide by the legal requirements associated with these

- Users may download and print one copy of any publication from the public portal for the purpose of private study or research.

- You may not further distribute the material or use it for any profit-making activity or commercial gain

If the publication is distributed under the terms of Article $25 \mathrm{fa}$ of the Dutch Copyright Act, indicated by the "Taverne" license above, 
STEEDS MOOIER 



\title{
STEEDS MOOIER
}

\author{
Over geschiedenis en zin van \\ vooruitgangsideeën in de kunst
}

\section{Proefschrift}

ter verkrijging van de graad van doctor aan de

Rijksuniversiteit Limburg te Maastricht, op gezag van de Rector Magnificus, Prof.dr. H. Philipsen, volgens het besluit van het College van Dekanen, in het openbaar te verdedigen op donderdag 27 oktober 1994 om 16.00 uur.

door

Ferdinand Maarten Doorman 
PROMOTORES:

Prof.dr.ir. G.H. de Vries

Prof.dr. M.S.G.K. van Nierop (Universiteit van Amsterdam)

BEOORDELINGSCOMMISSIE:

Prof.dr. J.H.W. Kusters (voorzitter)

Prof.dr. A.M. von Graevenitz (Universität zu Köln)

Prof.dr. A. Labrie

Prof.dr. J.J.A. Mooij (Rijksuniversiteit Groningen)

Prof.dr. L.M. de Rijk 
Voor Sigrid 
schenen en hoogstwaarschijnlijk zelfs nooit geschreven. Ik ben hem dan ook aanzienlijk meer dank verschuldigd dan de door Kant genoemde patiënt. Dat geldt ook voor mijn leermeester van het eerste uur, Maarten van Nierop, wiens nauwgezet lezen en ruimhartige scepsis mij voor een aantal uitwassen hebben behoed. Daarnaast gaat mijn dank uit naar prof.dr. Carel Blotkamp, dr. R.L.K. Fokkema, Hans van Straten en Willem Visser, die het manuscript of delen ervan van kritisch commentaar voorzagen, evenals Rein de Wilde en Jo Wachelder. De laatsten waren de afgelopen jaren met veel andere collega's uit Maastricht verantwoordelijk voor een intellectueel klimaat dat in deze voor universiteiten zo sombere tijden toch wel ongebruikelijk mag heten. Als laatste dient de eerste genoemd te worden naar wie mijn dank woor vool einvol commontaar on nog moor uitgaat, Sigrid Sijthoff. Aan haar draag ik dit boek op.

Amsterdam, juni 1994 


\section{Inhoud}

INLEIDING

Het tweede werk van Herakles

$\mathrm{Na}$ de geschiedenis

Waarvandaan, hoe en wat nu

I PERSPECTIEVEN OP VOORUITGANG: GESCHIEDENIS

De zin van ideeëngeschiedenis

Koselleck: de geschiedenis van een vooruitgangsbegrip $\quad 30$

Vooruitgangsbegrippen en verwante veranderingscategorieën

2 VAN KLASSIEKEN EN MODERNEN:

EEN OPENING NAAR DE TOEKOMST

De Querelle des Anciens et des Modernes

Een nieuwe blik op een oude kwestie

Volmaaktheid en vervolmaking

3 VAN ROMANTIEK TOT AVANT-GARDE

De negentiende eeuw: Comte en Spencer

De negentiende-eeuwse cultuurwetenschap:

van rotswand tot Rembrandt

Modernisme en avant-garde

4 OVER HET MAKEN VAN REVOLUTIE

De kleine Modernsky

Het heden als verleden van de toekomst $\quad 92$

De structuur van artistieke revoluties

Het vooruitgangsargument

Het museum van de periodisering

Vooruitgang als aporie 
5 VERNIEUWING IN DE POËZIE:

PODIUM EN DE BEWEGING VAN VIJFTIG

I 2 I

$\mathrm{Na}$ de oorlog

De beweging van Vijftig: vooruitgang?

Op de planken van het jonge Podium

Van Sierksma naar Rodenko

De jongens op het podium

Er was geen terug meer

Eerst alle oude pikken uitroeien

Literatuurgeschiedenis als vooruitgang

\section{VERNIEUWING IN SCHILDERKUNST EN}

ARCHITECTUUR: DE STIJL

Abstractie en de schoonheid van een graansilo

De nieuwe stijl en de tijdgeest

Vernieuwing in de architectuur

Vernieuwing in de schilderkunst

Consequente doorvoering

De artistieke revolutie van De Stijl

De Stijl en het nageslacht

De cake-walk in het heden

Apotheose der avant-garde: het einde van de kunst

8 STEEDS MEER EN STEEDS RIJKER

Vooruitgang in de kunsten: steeds meer

Cognitieve vooruitgang: kunst als kennis 


\section{Inleiding}

Het tweede werk van Herakles

Aan het voorwoord van zijn Philosophische Untersuchungen liet Ludwig Wittgenstein een motto voorafgaan van de negentiende-eeuwse Oostenrijkse toneelschrijver en satiricus Nestroy: 'Ueberhaupt hat der Fortschritt das an sich, daß er viel größer ausschaut, als er wirklich ist.' Dit motto, aldus de inleiding tot de Nederlandse vertaling, slaat eigenlijk nergens op, want Wittgenstein heeft het in de Philosophische Untersuchungen nooit over historische zaken of processen, laat staan over vooruitgang. Zijn filosofie sluit ook uit dat over een verschijnsel als vooruitgang iets zinnigs kan worden beweerd. Daarom, schrijft de inleider, 'blijft het min of meer raadselachtig, waarom Wittgenstein tot de keuze van juist dit citaat gekomen is'. ${ }^{1}$

Die raadselachtigheid kleeft steeds aan de manier, waarop de idee van vooruitgang in deze eeuw weer opduikt. Vooruitgang, zo hoort men voortdurend, is een verouderde idee, gebaseerd op een metafysische geschiedopvatting waar reeds lang mee is afgerekend. Vooruitgang, zo luidt de gangbare mening, was het geloof van de negentiende eeuw, een geloof dat toen al aan kritiek blootstond, maar dat definitief gevonnist werd met het uitbreken van de Eerste Wereldoorlog, een gebeurtenis die het optimistische Westen de schellen van de ogen deed vallen. ${ }^{2}$ Vooruitgang, zo wordt telkens opnieuw geconstateerd, is de fossiele brandstof die de grote verhalen van de geschiedenis en de rampzalig gebleken ideologieën lang gaande heeft gehouden, een brandstof die nu eindelijk is uitgeput. Of, zoals Gerard Reve het eens kernachtig samenvatte: 'Vooruitgang bestaat niet, en dat is maar goed ook, want zoals het is, is het al erg genoeg.' 3

Het is dan ook merkwaardig dat filosofen van de twintigste 
eeuw onophoudelijk bezig zijn geweest om een geloof of een idee af te zweren, die volgens de communis opinio van hun vakgebied eigenlijk al sinds jaren achterhaald is. Een aanzienlijk deel van de wijsgerige arbeid van deze eeuw heeft aldus veel weg van het geploeter waarvoor Herakles zich gesteld zag toen hij de koppen van de vreselijke Hydra moest afslaan, terwijl bekend was dat ze onmiddellijk weer aan zouden groeien. De naam van het veelkoppige monster is Vooruitgang: de mythologische lading van dit begrip doet niet onder voor die van het gedrocht dat Herakles onder handen nam. Maar de laatste had meer succes dan de filosofie in haar worsteling met Vooruitgang, want nog altijd is het de vraag of het wijsgerig werk inmiddels voltooid is. Moet Nestroy's motto niet eerder worden omgedraaid, hat der Fortschritt nicht das an sich, daß er viel kleiner ausschaut, als er wirklich ist?

Zo richt een omvangrijk deel van vooral het continentale denken van deze eeuw zich op wat onze door technologie beheerste cultuur wordt genoemd. In de invloedrijke filosofie van de latere Heidegger, maar niet minder in die van zulke uiteenlopende auteurs als Lewis Mumford, Hans Jonas, Hannah Arendt en Arnold Gehlen klinkt als onafgebroken grondtoon een fundamentele kritiek mee op het westerse vooruitgangsdenken, op een voortschrijdende technologie die vanuit een even fataal als kortzichtig geloof het bestaan, de cultuur of het leven allengs meer veronachtzaamt en bedreigt.

Ook in de traditie van de Frankfurter Schule, en dan in de eerste plaats sinds het verschijnen van Horkheimers en Adorno's Dialektik der Aufklärung ( 1947), vormt de kritiek op 'het destructieve van de vooruitgang', op le prix du progrès, een zelden ontbrekend bestanddeel.4 Belangrijke naoorlogse denkers als Marcuse en Habermas hebben veel aandacht besteed aan een als instrumenteel of technisch gekarakteriseerde rationaliteit; in hun analyse daarvan worden ontwikkelingen doorgelicht en aan de kaak gesteld die bij nader inzien maar al te vaak als het geraamte van een impliciete vooruitgangsideologie kunnen worden herkend.

Bij een filosoof als Foucault komt dat in nog sterkere mate 
naar voren. Zijn werk kan begrepen worden als een nietaflatend gevecht met het monster dat Vooruitgang heet. Enerzijds brengt zijn historisch werk vanuit talloze invalshoeken de structuren aan het licht waarmee de als vooruitgang begrepen ontwikkeling van onze cultuur ontmaskerd wordt als cen juist toenemende disciplinering en beheersing van het menselijk bestaan. Anderzijds beklemtoont hij als historicus telkens de breuken in het verleden en neemt hij de discontinuilteit tussen verschillende periodes tot vertrekpunt van dergelijke ontmaskeringen.

In andere regionen van de filosofie waart dezelfde hydra van de vooruitgang rond, bijvoorbeeld in de debatten die vanaf Thomas Kuhns baanbrekende The Structure of Scientific Revolutions (1962) in de wetenschapsfilosofie zijn gevoerd. Weliswaar gingen deze discussies het meest expliciet over de vermeende rationaliteit waarmee wetenschap zich ontwikkelde, maar onder de oppervlakte speelde voortdurend de vraag mee, in hoeverre die ontwikkeling als een vorm van vooruitgang kon worden opgevat, als een steeds verder voortschrijden in kennis. Uitgerekend hierin school het engagement waarmee deze strijd werd aangegaan.

Het misschien wel meest opvallende gebied waarin vooruitgangsideeën zich even krachtig als onzichtbaar, of beter: op een nauwelijks gereflecteerde manier manifesteerden, is het terrein van de kunsten. Terwijl in onze eeuw de vraag naar de betekenis en zinvolheid van dergelijke ideeën in de kunst vrijwel nooit meer aan een serieuze analyse werd onderworpen, was de vooruitgangsgedachte tegelijkertijd een van de meest cruciale uitgangspunten van de avant-garde, en eigenlijk van alle stromingen en bewegingen (reeds veelzeggende substantiva) in de moderne kunst. Kunstwerken die niet 'modern' waren of zich niet lieten beschrijven in termen van een impliciet vooruitgangsjargon, telden lange tijd nauwelijks mee. Pas met het tegenwoordig veelbesproken eind van de avant-garde, met de sinds enkele decennia steeds vaker geconstateerde 'crisis' in de hedendaagse kunsten en met de algehele verbreiding van het postmoderne gedachtengoed ontstaat er enige reflexieve be- 


\section{Steeds mooier}

langstelling voor de zo invloedrijke historische categorie van vooruitgang.

\section{Na de geschiedenis}

Er is iets aan het veranderen in de kunst. Of dit de laatste tien jaar zo is, of de laatste vijftig jaar, valt moeilijk te zeggen. Het gaat om een complex verschijnsel bij zeer uiteenlopende kunsten in nięt minder verschillende landen en culturele tradities. Hoewel er in de westerse samenleving steeds meer aandacht aan kunst wordt besteed, heerst er tegelijkertijd een soort stuurloosheid, een gevoel van ijdelheid en willekeur dat deze aandacht uitholt, vluchtig maakt. De voorspelbare toekomst en een bevattelijk geordend verleden beginnen langzamerhand uit zicht te raken en daarmee de oriëntatie in het heden. De kunsten lijken in de pluriformiteit van het eigen succes hun identiteit en zeggingskracht te verliezen.

Dergelijke intuïties en opvattingen leven onder kunstenaars, critici en consumenten van elke kunsttak. Nieuwe composities in de hedendaagse muziek dreigen steeds in de marge terecht te komen of te blijven, terwijl er door de enorme veelvormigheid weinig overeenstemming meer bestaat over welke ontwikkelingen er eigenlijk toe doen. In de literatuur is de tijd van de experimentele roman voorbij, evenals een omvangrijke reeks vernieuwingen in de poëzie; men valt op oude vormen terug of zet ze voort. De architectuur heeft zich de laatste twintig jaar aan een lang overheersend functionalisme ontworsteld en citeert nu met meer of minder exuberantie uit de rijkdommen van het verleden. Tijdschriften over beeldende kunst en kunstenaars discussiëren al jaren over het einde van de schilderkunst.

Deze hele ontwikkeling, of misschien juist dit gebrek aan ontwikkeling, gaat met een zeker onbehagen gepaard. Is alles al gedaan en gezegd, is vernieuwing niet meer mogelijk? Was het fin de siècle van honderd jaar geleden slechts een kortstondige voorafspiegeling van het allesverpletterende finis millennii dat ons nu te wachten staat? Zijn we op het gebied van de kunst 


\section{Inleiding}

werkelijk in een post-historische tijd terechtgekomen, waarin alles kan en dus niets meer telt? Het is duidelijk: de kunsten hebben het moeilijk en er gaan stemmen op dat ze hun tijd hebben gehad.

Een van de belangrijkste hedendaagse vertegenwoordigers van deze idee is de Amerikaanse filosoof en kunstcriticus Arthur Danto, die zijn veelbesproken stelling over het einde van de kunst van een filosofische fundering voorziet door precies het concept van vooruitgang in de kunst aan te vallen. Danto gaat een stap verder dan de vele schrijvers, critici en kunstenaars die in de voorafgaande jaren het eind van de avant-garde en het modernisme hebben verkondigd; hij ziet het tijdsgewricht van nu als het eindpunt van een veel langere ontwikkeling.s

Zijn fascinerende relaas beperkt zich tot de beeldende kunsten, maar heeft een ruimere strekking. Danto stelt dat er drie modellen zijn om de geschiedenis van kunst te beschrijven. Het eerste beschouwt kunst als representatie van de werkelijkheid, en haar geschiedenis als een geleidelijk betere weergave van die werkelijkheid. (Vasari beschreef dit destijds voor een beperkte periode - van Cimabue tot Michelangelo - en deze eeuw verdedigde de kunsthistoricus Gombrich het voor een veel langere termijn.) Op een gegeven moment is verdere perfectionering niet meer mogelijk. Schilderkunst en sculptuur worden bijvoorbeeld door de filmkunst voorbijgestreefd, die immers beweging in beeld brengt en aldus de werkelijkheid veel dichter benadert. De uitweg van de abstracte kunst is binnen dit model een doodlopende weg, want een verwijdering van het ideaal van een volmaakte, door Danto optisch opgevatte, mimesis. ${ }^{6}$

De tweede vorm van kunstgeschiedenis ziet kunst als expressie. Danto presenteert deze benadering als een vluchtroute voor beeldende kunstenaars uit het begin van deze eeuw, die zich van het failliet van representerende kunst bewust werden. In deze geschiedopvatting is vooruitgang even onzinnig als in het vorige geval, omdat er geen 'mediating technology of expression' valt aan te wijzen. Waar de middelen om de realiteit weer te geven nog als een reeks voortschrijdende technieken en kunstgrepen (zoals de uitvinding van het perspectief) konden worden 


\section{Steeds mooier}

beschreven, is dit bij expressie niet mogelijk. Kunstgeschiedenis is zo beschouwd niet meer dan een opeenvolging van losse, min of meer artistiek geslaagde uitingen, een soort biografieënreeks zonder vooruitgang. 7

Het derde, door Danto vertolkte soort kunstgeschiedenis ziet kunst op een hegeliaanse manier als een vorm van zelfbegrip, waarin het theoretische bestanddeel allengs groter wordt, totdat het conceptuele gehalte zo omvangrijk is dat kunst in filosofie overgaat. Danto verdisconteert hier overtuigend het autonome karakter van de hedendaagse kunst en het overheersend geworden gehalte aan commentaar, verwijzingen en zelfreferentie. Kunst wordt zich in toenemende mate van zichzelf bewust en een object voor zichzelf. In dit geval is ook geen sprake meer van onophoudelijke vooruitgang, maar net als bij Hegel van een eindpunt, een eindpunt dat in de ogen van Danto inmiddels voor de beeldende kunsten is bereikt. Zo is de Brillo Box van Andy Warhol nog uitsluitend op grond van een conceptuele benadering als kunst te begrijpen. Daarom is kunst definitief geschiedenis geworden. In deze postmoderne en post-historische tijd kan nog heel goed kunst worden gemaakt, maar zij is van bijna alle belang gespeend, of liever gezegd, de kunst is door haar conceptuele lading tot filosofie getransformeerd. ${ }^{8}$ Dat maakt haar volgens Danto juist zo interessant.

\section{Waarvandaan, hoe en wat $n u$}

Naar aanleiding van dergelijke kwesties wil dit boek enig licht werpen op de vaak impliciet blijvende, maar invloedrijke manier waarop over vooruitgang in de kunst wordt nagedacht. Hoe verhouden we ons tot het imponerende verleden van de kunst? Lopen de kunsten werkelijk op hun eind en getuigt de veelheid aan kunstvormen en de onoverzichtelijke stand van zaken in bijna elke tak van hedendaagse kunst inderdaad van een algemene crisis, zoals telkens in kranten, documentaires, kunsttijdschriften en esthetische verhandelingen valt te vernemen? Er doet zich hier een tweevoudig probleem voor. Allereerst de 


\section{Inleiding}

geconstateerde crisis zelf, die met postmoderne theorieën wel verklaard, maar niet opgelost kan worden. Verder de dubbelzinnigheid van de filosofische kritiek, die sinds lang op vooruitgangsideeën is losgelaten op de impliciete en indirecte wijze die boven werd geschetst.

Om te beginnen vereist dit laatste probleem, de kritiek op vooruitgangsbegrippen, meer aandacht. Valt er eigenlijk wel iets zinnigs over Vooruitgang te beweren, zoals aan de hand van de latere Wittgenstein inderdaad betwijfeld kan worden? Om daar een antwoord op te kunnen geven dient die vraag op zijn minst wat anders gesteld te worden, namelijk: boe zijn (en worden) vooruitgangsbegrippen gebruikt, in welke historische context figureren ze en welke functie hebben ze daar?

Dergelijke vragen geven al aan dat dit boek een zowel historische als systematische invalshoek heeft. Het probeert een empirische benadering te combineren met een meer theoretische aanpak, waarbij nauwelijks geaarzeld zal worden om het met het voor filosofen zo traditionele gebrek aan bescheidenheid over alle kunsten te hebben. Deze aanpak leidt tot de tegenwoordig veel gepropageerde interdisciplinariteit in de cultuurwetenschappen, die bij het schrijven echter niet zozeer een uitgangspunt was als wel een resultaat bleek te zijn. Cultuurfilosofie, ideeëngeschiedenis, kunst- en literatuurgeschiedenis, esthetica en theoretische geschiedenis gaan in de komende hoofdstukken steeds in elkaar over.

In dit boek komen achtereenvolgens drie vragen aan de orde. Ten eerste, waar en op welke manier ontstond het denken in termen van vooruitgang in de kunsten? Vervolgens, hoe werden vooruitgangsbegrippen hier gebruikt? En ten derde: wat is de zin en betekenis van zulke begrippen in de discussie over hedendaagse kunst? Een van de onverwachte koppen van de vooruitgangshydra doemt al meteen in het eerste, wellicht meest theoretische hoofdstuk op, waar blijkt hoe moeilijk de geschiedenis van het vooruitgangsbegrip zelf te ontdoen is van de noties die uit dit begrip voortspruiten. Er zal worden betoogd dat het weinig zin heeft de geschiedenis van het vooruitgangsbegrip te volgen als een ontwikkeling vanaf de Grieken tot heden. $\mathrm{Na}$ 
het pleidooi voor een middenweg tussen te globaal realisme en te veel op context gefixeerd nominalisme volgt een beschrijving van het ontstaan van een nieuw historisch besef in de achttiende eeuw.

Deze beschrijving bereidt het volgende hoofdstuk voor, waarin de geschiedenis van vooruitgangsbegrippen in de kunst contouren zal krijgen. Die geschiedenis begint met de befaamde Querelle des Anciens et des Modernes aan het eind van de zeventiende eeuw en geeft weer hoe tijdens de verlichting langzamerhand vooruitgangsnoties opkomen, waarin finalistisch denken op de achtergrond raakt. Het derde hoofdstuk vormt de andere helft van deze kleine ideeëngeschiedenis; hier passeren opvattingen over revolutie, ontwikkeling, evolutie en vooruitgang in de kunst de revue vanaf de romantiek tot en met de moderne avant-garde.

Het tweede deel van dit boek gaat meer systematisch in op de vraag hoe zulke begrippen in de loop der tijd zijn gebruikt. In hoofdstuk vier wordt een beroep gedaan op het model voor wetenschappelijke revoluties van Thomas Kuhn, om aldus beter zicht te krijgen op artistieke veranderingen, die vaak breuksgewijs plaatsvinden en met een revolutionaire retoriek worden gepresenteerd. Op die manier kunnen redenen worden gezocht voor de grote rol die vooruitgangsbegrippen in de kunst hebben gespeeld en misschien nog spelen.

De volgende twee hoofdstukken bestaan elk uit een gevalstudie die moet verduidelijken hoe vooruitgangsbegrippen in de praktijk van een artistieke vernieuwingsbeweging gebruikt worden en functioneren. Onderwerp van deze studies is beide keren een tijdschrift, dat opmerkelijke fenomeen dat in zijn naam en als verschijnsel al veel weg heeft van een voertuig van vooruitgangsideeën. De volgorde van deze twee praktijkgevallen is niet-chronologisch, een misschien wat simpele ingreep om aan te geven dat dit boek niet louter een historische studie van vooruitgangsideeën in de kunst behelst.

De eerste gevalstudie gaat in op de vernieuwing van de naoorlogse Nederlandse poëzie door de Beweging van Vijftig. Hier worden de eerste tien jaar bestudeerd van het belangrijkste tijd- 
schrift waarin deze vernieu wing destijds zichtbaar werd, namelijk Podium. De volgende gevalstudie is een soortgelijk onderzoek naar de veranderingen in de architectuur en de schilderkunst die door De Stijl teweeg werden gebracht. Ook hier dienen de teksten uit het gelijknamige tijdschrift (1917-1931) als uitgangspunt om vast te kunnen stellen hoe de betrokkenen zelf hun werk in termen van vooruitgang presenteerden en begrepen. Verder wordt in beide hoofdstukken de vraag opgeworpen of anderen deze veranderingen later als vooruitgang interpreteerden. Tot slot komt hier het probleem op of die veranderingen nu nog als vooruitgang zijn op te vatten en zo ja, waarom.

Die vraag keert expliciet terug in het derde deel. De laatste twee hoofdstukken nemen de problemen weer op die aan het eind van het derde en het vierde hoofdstuk al opdoemden: de post-historische verwarring die volgt op het eind van de avantgarde, de kunst als permanente en zich steeds versnellende revolutie en de gevolgen van een radicale ontkenning van vooruitgang in de hedendaagse kunsten, zoals Danto die aan de orde heeft gesteld. Er zal aan het slot worden betoogd dat vooruitgang in deze context geen zinledig begrip is en dat er goede argumenten zijn om ontwikkelingen in de kunst als vooruitgang te begrijpen. Een herwaardering van het vooruitgangsconcept is bovendien een belangrijk middel om de als zorgeloosheid vermomde vrijblijvendheid van het postmodernisme in de kunsten te keren, dat wil zeggen: te overwinnen en voorbij te streven. 


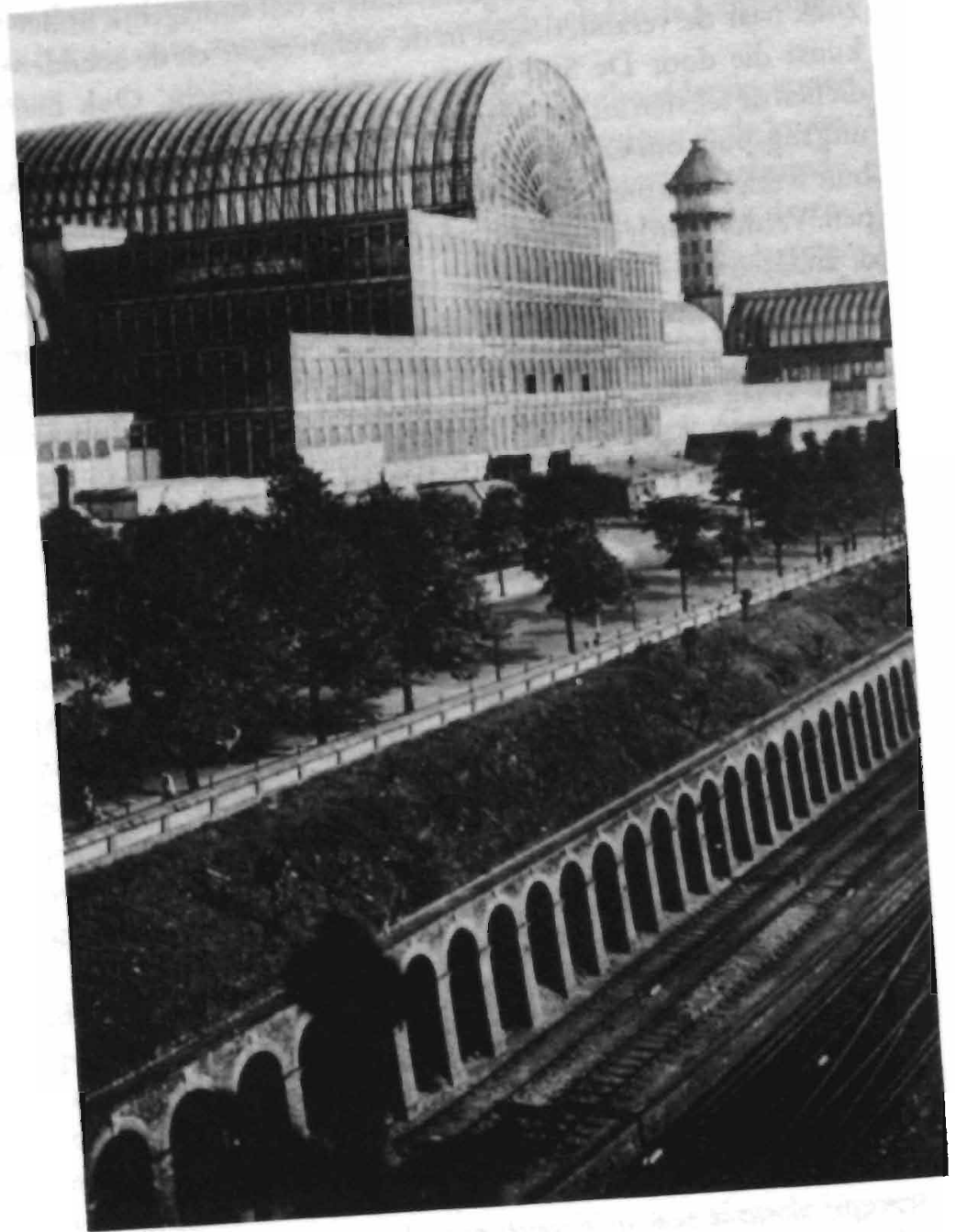

Achterzijde van Crystal Palace en de spoorweg die bezoekers van alle kanten aanvoerde 


\title{
I Perspectieven op vooruitgang: geschiedenis
}

\author{
The Great Exhibition
}

In 185 I werd in Londen de eerste wereldtentoonstelling gehouden. Het middelpunt van deze manifestatie was een enorme glazen kas, waarin gemakkelijk zeven voetbalvelden zouden passen. Door het glas van dit roemruchte Crystal Palace viel van alle kanten licht op een keur aan verworvenheden en nieuwe vindingen uit de westerse beschaving. Hier kon men zich vergapen aan de pas uitgevonden schrijfmachine, aan de stoomhamer van Nasmyth, aan een naaimachine en aan een blok kwaliteitsstaal van 2000 kilo dat door de Duitse firma Krupp vervaardigd was. Zelfbewust en vervuld van bewondering schreef een tijdgenoot:

Het Huis van Glas zal in de annalen van de geschiedenis voortbestaan, nog lang nadat de overschatte piramides van Egypte [...] tot stof zullen zijn vergaan.'

De waren die in de gigantische etalage van de Great Exhibition lagen uitgestald, moesten in de eerste plaats aan de man gebracht worden, maar ze lagen er niet om louter commerciële redenen te schitteren. De Britse bezienswaardigheden gaven ook uitdrukking aan nationale trots door de voorsprong op de rest van de wereld te illustreren. In meer algemene zin was de tentoonstelling bovendien bedoeld als mijlpaal in de geschiedenis, als ijkpunt in de ontwikkeling van de menselijke beschaving. The Economist van 4 januari i 8 s I schreef:

Of that wonderful half century the Great Exhibition is both a fitting close and a fitting commencement of the new balf 
century, which will, no doubt, surpass its predecessor as much as that surpassed all that went before it [...] All who have read, and can think, must now have full confidence that the 'endless progression' ever increasing in rapidity [...] is the destined lot of the human race. ${ }^{2}$

In Crystal Palace lag een idee tentoongesteld: de idee van vooruitgang. De industriële revolutie van de laatste honderd jaar had grote veranderingen in de samenleving gebracht en hoewel maatschappijcritici en schrijvers als Dickens en Dostojevski de schaduwzijden daarvan lieten zien, heerste er in alle lagen van de bevolking een bijna allesbeheersend geloof in vooruitgang. Het ging goed met de mensheid en het zou steeds beter gaan.

Vooruitgangsideeën worden meestal met dit ongebreidelde negentiende-eeuwse optimisme in verband gebracht en als zodanig lijken ze geschiedenis. Maar het is een geschiedenis die niet voorbij is. Wie wil weten hoe dergelijke begrippen tegenwoordig functioneren, zal zich in deze geschiedenis moeten verdiepen, omdat allerlei historische noties in die begrippen door blijven klinken en omdat zo kan worden aangegeven dat dergelijke veranderingscategorieën complexer zijn dan de monolithische vooruitgangsidee van de negentiende eeuw soms achteraf suggereert.

Sinds het begin van deze eeuw is over het ontstaan en de geschiedenis van vooruitgangsideeën veel geschreven. Een voorbeeld van zo'n begripsgeschiedenis is The Idea of Progress van Bury, een vaak genoemd overzicht dat representatief is voor een groot deel van de historische vooruitgangsliteratuur. 3 Bury verstaat onder vooruitgang de idee dat 'civilisation has moved, is moving and will move in a desirable direction' (p.2). Hij begint zijn zoektocht naar de oorsprong van deze idee in de oudheid, waar hij echter weinig aanknopingspunten aantreft. Want de Grieken hadden nog geen lange, vastgelegde voorgeschiedenis die een notie van vooruitgang mogelijk makte, hoewel de gedachte reeds bestond dat de beschaving uit een onbeschaafde toestand voortkwam. Daarnaast werd verandering in het algemeen negatief gewaardeerd en hadden vervaltheorieën en een 
cyclische geschiedopvatting de overhand. Bury vindt in de oudheid slechts een aanzet van vooruitgangsdenken in de epicureische traditie, bijvoorbeeld in enkele passages uit Lucretius' $D e$ Rerum Natura.

De middeleeuwen blijken voor Bury evenmin een geschikte voedingsbodem om zijn concept te laten ontkiemen. Een belemmering is de dan nog heersende idee van een eindtijd, zoals in de Openbaring wordt verkondigd. Ook het beeld van een almachtige Voorzienigheid acht Bury strijdig met zijn vooruitgangsbegrip, dat de mens zelf aan verbetering wil laten bijdragen. Pas in de late renaissance wordt het klimaat geschikt voor vooruitgangsideeẻn, wanneer de klassieken niet meer klakkeloos worden nagevolgd en er zich verzet tegen de oudheid begint af te tekenen. Bury beklemtoont hier de rol van de zestiende-eeuwers Jean Bodin en Louis Le Roy, die stellen dat de wereld niet in verval is, dat hun eigen tijd niet minder waard is dan de oudheid en dat er zoiets als een 'wereldrepubliek', en daarmee vooruitgang op mondiale schaal mogelijk wordt.

Een volgende stap in de ontwikkeling van de vooruitgangsidee ligt volgens Bury bij Descartes, wiens theorie van een onafhankelijke rede de plaats inneemt van op autoriteit van de Voorzienigheid stoelende opvattingen. Belangrijk is voorts de Querelle des Anciens et des Modernes aan het eind van de zeventiende eeuw, een polemiek over de vraag of de kunsten (artes) in de oudheid zo volmaakt waren dat zij nooit overtroffen konden worden. In de achttiende eeuw vindt in Bury's beschrijving een volledige ontplooiing van de vooruitgangsidee plaats, om te beginnen in Frankrijk. Op een groot aantal terreinen worden ontwikkelingen nu als vooruitgang begrepen; sociaal, staatkundig (Abbé de Saint-Pierre), cultureel, wetenschappelijk, moreel (Encyclopedisten) en economisch (Quesnay, Mirabeau). In Engeland en Duitsland doet zich globaal, zij het wat later, een vergelijkbare ontwikkeling voor. Bury laat vervolgens zien hoe veelomvattend het begrip sinds het Duitse idealisme geworden is; hij behandelt de Franse utopisten en Comte, John Stuart Mill, Spencer en een aantal mindere goden, om te concluderen dat de geschiedenis van de idee ten slotte 
gelijke tred lijkt te houden met de groei van de moderne wetenschap, van een niet nader door hem omschreven 'rationaliteit' en met de strijd voor politieke vrijheid en godsdienstvrijheid.

In de geschiedschrijving van Bury steekt - net als bij talrijke vergelijkbare studies - de hydra van de vooruitgang voortdurend de kop op: zonder dat hij zich ervan bewust lijkt te zijn, beschrijft hij de geschiedenis van het begrip in termen van het begrip zelf. Bury vergaapt zich aan het denken over vooruitgang zoals men destijds de schrijfmachine, de stoomhamer van Nasmyth en Krupps kwaliteitsstaal als resultaten van de Vooruitgang bewonderde. Met bijna aanstekelijk enthousiasme vertrekt hij vanuit een begripsrealisme waarin wordt aangenomen dat 'vooruitgang' in wezen als een soort eeuwig, platoons idee altijd bestaan heeft, en slechts in de loop der tijd tot ontplooiing moest komen, zonder dat hij zich realiseert dat deze vooruitgang een tamelijk recente uitvinding is.

Als vele ideeënhistorici stelt Bury aan de geschiedenis, dat wil zeggen aan het ter beschikking staande bronnenmateriaal, de vraag wanneer dit concept zich begint te manifesteren, en hoe. Deze aanpak is een treffend voorbeeld van wat tegenwoordig als de whig interpretation of history wordt omschreven, een benadering waarin het verleden op een vloeiende manier naar het heden - en dus vanuit het heden - wordt gemodelleerd.4

Zo'n interpretatie van het uitgebreide, de hele geschiedenis van het westerse denken betreffende bronnenmateriaal kan behoorlijk verschillen. Zo ontwaart Bury niet meer dan een kiem van de vooruitgangsidee in de oudheid en plaatst hij het 'werkelijke begin' in de zestiende eeuw, terwijl de socioloog en historicus Nisbet in zijn met Bury's werk vergelijkbare History of the Idea of Progress (1980) vanuit een met christelijk erfgoed doortrokken referentiekader de oudheid als voorbode opvat van de al volledige ontplooiing van de idee bij kerkvader Augustinus. Hoewel Nisbet van een sterk op dat van Bury lijkend vooruitgangsconcept uitgaat, komt hij tot een volkomen spiegelbeeldig resultaat. Volgens hem ontbreekt het concept bijvoorbeeld in de renaissance, terwijl bij Bury de idee dan juist zichtbaar begint te 
worden. De grote rol die Bury aan de Querelle des Anciens et des Modernes toekent, wordt door Nisbet expliciet ontkend, enzovoort. Welbeschouwd gaan de begripsgeschiedenissen van Bury en Nisbet niet in de eerste plaats over de geschiedenis van 'het' vooruitgangsdenken, maar over opvattingen van Bury en Nisbet zelf, over hun eigen idee van zingeving die op de geschiedenis wordt geprojecteerd.

Een dergelijk begripsrealisme, dat de geschiedenis zelf ook in termen van vooruitgang en ontwikkeling construeert, is representatief voor veel historische literatuur over vooruitgang - en voor een groot deel van de traditionele ideeëngeschiedenis hoewel niet alle studies tot de oudheid teruggaan. Maar ook als ze een latere en kortere periode onder de loep nemen, wordt een al dan niet expliciet gedefinieerd vooruitgangsbegrip gehypostaseerd en als een thermometer in de geschiedenis gedompeld om de vooruitgangstemperatuur te bepalen.

\section{De zin van ideeëngeschiedenis}

Het is inmiddels nauwelijks meer de vraag, hoe vruchtbaar dit soort ideeëngeschiedenis is. Toch is het zinvol hier een ogenblik bij stil te staan, omdat ideeën over geschiedenis, historische categorieën, of hoe men ze ook noemen wil, nooit geheel onafhankelijk van hun eigen intellectuele voorgeschiedenis kunnen worden beschreven. Dat geldt in het bijzonder voor vooruitgangsbegrippen, zoals in dit hoofdstuk zal worden beargumenteerd en ook op andere plaatsen in dit boek nog zal blijken.

Vijfentwintig jaar geleden sneed de historicus Quentin Skinner de problematiek van ideeëngeschiedenis aan in zijn inmiddels beroemd geworden artikel 'Meaning and understanding in the history of ideas'. Een van Skinners belangrijkste bezwaren tegen benaderingen als die van Bury richtte zich op wat hij een mythology of doctrines noemde, waarin aan schrijvers uit het verleden ten onrechte allerlei standpunten worden toegeschreven. Dit gebeurt op verschillende manieren, zo betoogde Skinner. Bijvoorbeeld door verspreide en incidentele opmerkingen 
die bij de gezochte idee aansluiten naar voren te halen, zodat een auteur opvattingen in de mond worden gelegd die hij nooit had kunnen verdedigen.s

Een verwante manier is - en hier haalde Skinner de pionier van deze benadering, Arthur O. Lovejoy, misprijzend aan - om de 'morfologie' van een gegeven idee of theorie op te sporen 'through all the provinces of history in which it appears' ${ }^{6}$ In dit geval neemt men een ideaaltype van zo'n idee of theorie (gelijkheid, vooruitgang, het sociaal contract, enzovoort) als metafysisch uitgangspunt. Dat leidt tot historische absurditeit, aldus Skinner, wiens artikel niet van enige analytische vechtlust gespeend was.

Ten eerste tot de absurditeit van een veronderstelde anticipatie van een idee. Deze door Skinner gelaakte denkfiguur valt ook goed aan de hand van Bury te illustreren. Zo beweert de laatste dat Jean Bodin in de zestiende eeuw met een nieuwe theorie over universele geschiedenis kwam, die met haar drievoudige periodisering anticipeerde op Hegels indeling in oosterse, klassieke en Germaanse werelden. 7 Omdat de werkelijke invloed van Bodin op Hegel niet wordt aangetoond en de context van beide theorieën nogal uiteenloopt, krijgt zo'n opmerking een behoorlijk gratuit karakter. Nu treedt volgens Skinner nog eens een vergelijkbare absurditeit op bij de vraag wanneer een bepaalde idee 'werkelijk opkwam'. Ook hiervan is Bury's boek een prachtige illustratie. We zien hem telkens in een ver en duister verleden turen, op zoek naar een idee die echter in de praktijk en de discussies van zijn eigen tijd pas betekenis krijgt.

Skinners kritiek, geïnspireerd door de betekenistheorieën van de late Wittgenstein, sneed hier onmiskenbaar hout. Wanneer de betekenis van een begrip als een onveranderlijke idee wordt opgevat die onafhankelijk van de historische context kan worden beschreven, wordt historisch onderzoek naar die betekenis een hachelijke onderneming. Zijn kritiek reikte echter verder; hij achtte onderzoek naar de ontwikkeling van een begrip of idee buiten de linguïstisch en sociaal bepaalde praktijk van een beperkte periode hoe dan ook zinloos en ontkende daarmee in feite de mogelijkheid van ideeëngeschiedenis überhaupt. Elke 
vorm van zo'n geschiedenis zou zich onvermijdelijk verstrikken in de door hem gesignaleerde drogredenen (p.36-38).

Op dit ideeënhistorisme van Skinner is de nodige kritiek te leveren. ${ }^{8}$ Allereerst is er een hermeneutisch bezwaar. We hoeven ons niet uitsluitend te beperken tot 'wie es eigentlich gewesen" is, want het is alleszins legitiem een tekst uit het verleden te lezen om ideeën en standpunten van onze eigen tijd, in confrontatie ermee of in het verlengde ervan, beter te leren begrijpen. Historische teksten kunnen dienen om onze eigen ideeën en vooronderstellingen te articuleren en hoeven niet enkel om zichzelfs wille te worden bestudeerd.

Belangrijker zijn twee andere bezwaren. Om te beginnen blijft de omschrijving van wat een taalspel, context, praktijk, conventie of historisch kader is, noodgedwongen vaag. Alleen al een chronologische afbakening is hier uiterst problematisch. Veel, zo niet alle teksten hanteren en beschrijven ideeën vanuit een intellectuele traditie die deze grenzen overschrijdt. Het 'taalspel' of de context van voor de ideeëngeschiedenis relevante discussies bestaat juist grotendeels uit teksten die buiten het chronologisch bepaalde kader vallen. Een interpretatie van een tekst uit het verleden kan zich nooit exclusief beperken tot de synchrone horizon van de schrijver.9

Een minstens even ernstig bezwaar is dat Skinners ideeënhistorisme elk historisch object willekeurig maakt. Zijn standpunt sluit immers het aanbrengen van grotere verbanden in de ideeëngeschiedenis uit. Het verleden valt op deze manier in het strooigoed van een aantal stukken tekst uiteen die bij gebrek aan samenhang schijnbaar willekeurig voor nadere bestudering bijeengebracht worden. In dit 'schijnbaar' schuilt de kern van dit bezwaar; de keuze voor een bepaald onderzoeksobject en de vraagstelling van waaruit dit object benaderd wordt, blijven goeddeels impliciet, en daarmee immuun voor reflectie of kritiek.

Aan de andere kant zijn er in deze benadering nauwelijks werkelijke redenen om die keuze te beperken; de historicus wordt gedwongen een wel heel ruime en verbrokkelde hoeveelheid materiaal te behandelen, want de criteria om de ene opvatting of 
tekst belangrijker te vinden dan een andere ontbreken nagenoeg. Als voorbeeld moge Skinners eigen studie dienen van politieke ideeën ten tijde van de renaissance en de reformatie. Het grote aantal theorieën dat hij in The Foundations of Modern Political Thought presenteert, levert een versplinterd beeld op, wat de onvermijdelijke prijs is voor de methodische zuiverheid die hij nastreeft. ${ }^{\circ}$ Bovendien geven de funderingen uit de titel van het boek te denken: ook de criticus zelf valt kennelijk voor de verleiding van anticipaties.

Historisch onderzoek kan niet zonder grote verbanden; of men die nu in de zogeheten colligerende concepten van W.H. Walsh, in de hermeneutisch-metaforische aanpak van een historicus als Hayden White of in de rehabilitatie van speculatieve theorievorming bij Huskell Fain probeert te vinden, de integratie van gebeurtenissen - of in het geval van ideeëngeschiedenis, teksten -is onontkoombaar. Men kan bijvoorbeeld Condorcets vooruitgangsbegrip alleen in het isolement van het decennium willen bestuderen, waarin zijn schets over de vooruitgang van de menselijke geest verscheen. Maar dan doet men hem te kort, omdat zijn uitlatingen een culminatie zijn van een aantal in de verlichting tot wasdom gekomen ideeën die door de toen gevoerde discussies te verhelderen zijn. En omgekeerd doet men hem te veel eer aan, door zijn opvattingen als volkomen uniek te zien. Het is in dit geval zelfs de vraag of kennis van de biografische en politieke omstandigheden het begrip van zijn Esquisse vergroten. Condorcets ongebreidelde vertrouwen in de perfectibiliteit van de mens wordt namelijk bizar, wanneer we de situatie waarin het werk ontstond in ogenschouw nemen: de Terreur bereikte een hoogtepunt, Condorcet was ondergedoken, werd gepakt en benam zich niet lang na de voltooiing van zijn optimistische geschrift het leven.

In de ideeëngeschiedenis is het aanbrengen van samenhang onontkoombaar. De invloedrijke benadering van Foucault probeerde dat op een andere manier dan de traditionele geschiedschrijving. Foucault besteedde veel aandacht an het taalgebruik in teksten uit het verleden. In zijn werk staan niet zozeer de intenties van de auteur voorop als wel de structuur van het 
vertoog (discours), dat wil zeggen de manier waarop in een bepaalde periode het schrijven en spreken zich in een samenleving voordoen. Die relatief stabiele structuur van het vertoog heeft als épistème een vergaande, ook kentheoretisch, antropologisch en sociologisch relevante strekking. Een nauwgezette bestudering van het vertoog zal niet beperkt blijven tot enkelvoudige gebeurtenissen, noch leiden tot vormen van historisme die de ideeëngeschiedenis onvruchtbaar zouden maken. Foucault meent eerder

dat wij door de 'korrel' van de gebeurtenissen tot het niterste te verkleinen, door het oplossend vermogen van bet historisch onderzoek op te voeren tot marktberichten, notariële akten, kerk- en havenregisters, die jaar na jaar, week na week gevolgd worden, voorbij de veldslagen, decreten, $d y$ nastieën en volksvergaderingen de contouren van omvattende verschijnselen van langdurige, eeuwen durende strekking voor ogen krijgen. "I

Foucault zet zich af tegen de continuïteitsgedachte die in de meeste ideeëngeschiedenissen naar voren komt. Met behulp van een monolithische karakterisering van zijn 'epistemen' brengt hij scherpe discontinuïteiten in de geschiedenis aan. Maar door de rigiditeit van deze breukvlakken wordt door hem een aantal verschijnselen over het hoofd gezien of juist bovenmatig uitvergroot: er ontstaan vertekeningen waarvoor alleen een extreem historisch relativist niet meer terugdeinst. ${ }^{12}$ Daarbij komt dat vooral in de geschiedenis van het denken 'verouderde' meningen en concepten steeds weer opduiken, zonder hun in een eerdere context of praktijk verkregen betekenis geheel af te leggen. Het standpunt van de volstrekte paradigmawisselingen houdt dan ook altijd iets geforceerds.

De kritiek van Skinner en Foucault op de traditionele ideeëngeschiedenis is grotendeels terecht en rekent overtuigend af met haar verborgen vooruitgangsnoties. Toch blijkt het resultaat wat mager wanneer we op hun manier proberen te ontdekken wat de historische discussies zijn waarin vooruitgangsbegrip- 
pen gestalte kregen en nog steeds functioneren. Precies hierbij kan de Begriffsgeschichte van de Duitse historicus, filosoof en socioloog Koselleck haar diensten bewijzen. In Kosellecks met Brunner en Conze geredigeerde lexicon Geschichtliche Grundbegriffe wordt een overzicht geboden van ongeveer is so voor de geschiedwetenschap belangrijke begrippen, waarbij de veranderende betekenis van die begrippen tussen 1750 en i 850 minutieus beschreven wordt. ${ }^{13}$ Weliswaar ontkomt Koselleck hierin niet in alle opzichten aan de verwijten van Skinner, maar hij laat wel zien hoe een zinvolle vorm van ideeëngeschiedenis mogelijk is door een uitvoerige empirische studie van uiteenlopend bronnenmateriaal - naast de klassieke teksten onder meer politieke redevoeringen, lexica, wetsteksten - te combineren met een ideeënhistorische analyse. ${ }^{14}$

Koselleck neemt hier en in ander werk, zoals nu beschreven zal worden, een vruchtbare positie in tussen enerzijds het al te caleidoscopische ideeënhistorisme en nominalisme van Skinner en anderzijds het begripsrealisme van historici als Bury. En hoewel de overgang naar een moderne, 'historische' tijd bij hem als een soort breukvlak kan worden opgevat, vervalt hij niet in de discontinuïteitsschema's van Foucaults epistemen, terwijl hij diens empirisch onderzoek naar uiteenlopend bronnenmateriaal en de semantische analyses daarvan naar de kroon steekt.

\section{Koselleck: de geschiedenis van een vooruitgangsbegrip}

Kosellecks Vergangene Zukunft uit I 979 begint met de beschrijving van een schilderij van Albrecht Altdorfer dat de slag bij Issus ( 333 voor Chr.) weergeeft. is Op dit schilderij uit i 529 wordt de overwinning van Alexander de Grote op de Perzen uitgebeeld. Een anachronisme dat tegenwoordig al snel op zal vallen, is het feit dat de Perzen 'vom Fuß bis zum Turban' zijn uitgedost in de zestiende-eeuwse kledij en wapenrusting van de Turken, die in I 529 voor de poorten van Wenen stonden. Deze discrepantie werd in de zestiende eeuw niet als zodanig ervaren; 
tegenwoordige en verleden tijd werden, zoals Koselleck het uitdrukt, nog door een gemeenschappelijke historische horizon omsloten. Zo'n driehonderd jaar later beschrijft en bewondert Friedrich Schlegel hetzelfde schilderij echter vanuit een heel ander historisch perspectief; hij meent er het 'höchste Abenteuer alten Rittertums' in te kunnen herkennen. Schlegel onderscheidt het aldus van de eigen tijd én van de oudheid. Wat is er in deze eeuwen in de historische tijdsbeleving veranderd, zo vraagt Koselleck zich af.

Deze in de achttiende eeuw opkomende, nieuwe tijdsbeleving van geschichtliche Zeit, waarin een aantal nieuwe historische begrippen - waaronder vooruitgang - opduiken, probeert Koselleck vanuit verschillende invalshoeken te beschrijven. ${ }^{16} \mathrm{Zijn}$ nauwkeurige behandeling van deze complexe verandering kan worden samengevat in een vijftal voor vooruitgangsbegrippen relevante kenmerken.

I. Een in het oog springende wijziging in de gangbare belevenis van de geschiedenis is de geleidelijke desintegratie van de christelijke eindtijdgedachte. Met de twijfel aan een dag des oordeels als afsluiting van de aardse geschiedenis begint een lineaire tijdsopvatting met open toekomst terrein te winnen. ${ }^{17}$ Dat de vanzelfsprekendheid van de jongste dag onder vuur kwam te liggen blijkt onder meer uit de rol die dit aan de Openbaring ontleende eindpunt ging spelen. Tijdens de reformatie en de daarmee samenhangende godsdiensttwisten werd de eindtijd steeds vaker op korte termijn aangekondigd om vervolgens weer te moeten worden uitgesteld. Daarmee boette de geschiedenis geleidelijk aan eschatologische betekenis in. Bovendien ging ook de eschatologische functie van het Heilige Roomse Rijk ten gevolge van internationale politieke ontwikkelingen allengs meer verloren. Zo werd een nieuw onderscheid als dat van Bodin tussen sacrale, menselijke en natuurlijke geschiedenis mogelijk. Voorts ontstond er steeds meer verzet tegen allerhande religieuze en politieke voorspellingen, aanvankelijk vanuit de opkomende ideologie van de absolute staat, die de destabiliserende effecten van zulke voorspellingen trachtte te bestrijden; verder vanuit de humanistische traditie. Van Mon- 
taigne en Bacon via Spinoza en Fontenelle tot Voltaire, wiens sarcasme 'nur noch der Spott eines Siegers ist', klinkt het literaire en filosofische verzet tegen allerhande vormen van profetie en waarzeggerij door. ${ }^{18}$

Met het verdwijnen van eindtijdverwachtingen ontstond een andere houding ten opzichte van de toekomst. Zo deed zich in het politieke denken de mogelijkheid van een rationele prognose voor, waarin de gebeurtenissen niet meer, zoals vanuit profetisch perspectief, symbolen waren en evenmin meer werden getoetst aan de jongste dag, maar waarin met verschillende beredeneerbare waarschijnlijkheden rekening werd gehouden. Tot op zekere hoogte gebeurde dit natuurlijk altijd al. Maar het veranderende toekomstbewustzijn ontnam de tijd zijn statische karakter; versnelling en vertraging, en daarmee de mogelijkheid tot het uitoefenen van invloed op meer globale historische processen, werden nu mogelijk geacht. Dit besef bood ruimte aan nieuwe ideeën over vooruitgang. Zo werd het concept van een versnelling in de tijd, eens een eschatologische categorie, getransformeerd in een oproep tot planning van een toekomst op aarde; men wilde (en geloofde) het betere sneller te bereiken en dacht daar invloed op te kunnen uitoefenen.

2. De veranderde beleving van een geschichtliche Zeit wordt door Koselleck gekarakteriseerd met wat hij de gelijktijdigheid van het ongelijktijdige noemt. ${ }^{19}$ In de zeventiende, maar vooral in de achttiende eeuw werden contacten met andere continenten en andere beschavingen omvangrijker en intensiever. De toenemende aandacht voor primitieve culturen leidde telkens tot een historische vergelijking met de eigen cultuur en daarmee tot een besef van ongelijktijdigheid, die zich chronologisch op hetzelfde tijdstip voordeed. Sommige volkeren of beschavingen - en dan natuurlijk vooral de eigen of meest verwante - werden als meer, en verder ontwikkeld beschouwd, al kon de confrontatie met een andere cultuur natuurlijk ook verval in de eigen samenleving aan de orde stellen, zoals Rousseau beoogde met zijn Discours sur les sciences et les arts ( 1750 ).

Een overeenkomstig tijdsperspectief doet zich voor bij het beschrijven van de stand van verschillende wetenschappen en 
theoretische denkbeelden, bijvoorbeeld in de Encyclopédie (1751-1772). Daarin heten belangrijke mannen bun tijd vooruit te zijn, terwijl de nog niet verlichte massa's het een en ander (met behulp van opvoeding) hebben in te halen. Met name de Encyclopedisten hebben vanuit een dergelijk historisch besef met verschillende vergelijkbare tijdstippen, ontwikkelingen en tijdlagen een soort raster ontwikkeld dat vooruitgangsideeën structureert: op dit raster voltrekt zich een universele geschiedenis.

De gelijktijdigheid van het ongelijktijdige markeert een veranderde tijdsbeleving; de dynamiek van gelijke ontwikkelingen in verschillend tempo, dus van ongelijktijdige ontwikkelingen in eenzelfde periode, maakt vooruitgang tot een historische ervaring. Deze dynamiek blijft een voortdurende rol in discussies over vooruitgang spelen. Vooral wanneer de spanning tussen cognitieve en morele ontwikkeling gethematiseerd wordt, een probleem dat Friedrich Schlegel formuleert in zijn kritiek op Condorcets Esquisse:

Das eigentliche Problem der Geschichte ist die Ungleichkeit der Fortschritte in den verschiedenen Bestandteilen der gesamten menschlichen Bildung, besonders die große Divergenz in dem Grade der intellektuellen und der moralischen Bildung. ${ }^{20}$

Ook Kant ervaart deze discrepantie. "Wir sind civilisirt bis zum Überlästigen,' zo schrijft hij,, ‘[a]ber uns für schon moralisirt zu halten, daran fehlt noch sehr viel.' ${ }^{21}$ Eenzelfde spanning doet zich voor bij het vergelijken van cognitieve en esthetische ontwikkelingen, zoals we in het volgende hoofdstuk zullen merken.

3. Een andere opvallende karaktertrek van de nieuwe tijdsbeleving van geschichtliche Zeit is de formulering van een aantal politiek-, sociaal- en historisch-theoretische termen in de vorm van een zogenaamd collectief enkelvoud (Kollektivsingular). ${ }^{22}$ In Historia Magistra Vitae beschrijft Koselleck hoe het enkelvoudig gebruikte woord Geschichte in de achttiende eeuw (in 
Duitsland) steeds meer de plaats in ging nemen van het woord Historie; het accent verschoof inhoudelijk van de gebeurtenis naar het gebeuren, van verslaggeving naar procesmatige, universele samenhang. Hiermee nam de exemplarische rol van de geschiedenis als magistra vitae af. Als geschiedenis ons al iets leerde, was dat voor zover van Historie werd afgezien.

Geschichte werd tot dan meestal als meervoud (geschiedenissen) gebruikt, maar kreeg rond 1770 in een nieuwe, enkelvoudige vorm de betekenis van een zelfstandige categorie die samenhangende processen onder één noemer bracht. In deze zin gaat geschiedenis, vooral vanaf de Franse Revolutie, ook als subject optreden, bijvoorbeeld waar Hegel spreekt van 'Arbeit der Geschichte'. Aan het eind van de negentiende eeuw, met de opkomst van het marxistische gedachtengoed, treden dergelijke vooronderstellingen over de werkzaamheid van de geschiedenis sterk op de voorgrond.

Het gebruik van dit collectieve enkelvoud doet zich ook voor bij een aantal andere historische, politieke en sociale categorieën; uit revoluties wordt nu de revolutie gedestilleerd, uit vrijheden de vrijheid en uit 'vorderingen' - les progrès, die Fortschritte - de vooruitgang: le progrès, der Fortschritt. ${ }^{23}$

4. De nieuwe beleving van geschichtliche Zeit uit zich verder in een veranderde wederzijdse verhouding tussen verleden en toekomst. In " "Erfahrungsraum" und "Erwartungshorizont" zwei historische Kategorien' beschrijft Koselleck een toenemende verwijdering tussen 'ervaring' uit het verleden en 'verwachting' voor de toekomst. ${ }^{24}$ Ervaringsruimte en verwachtingshorizon zijn geen symmetrische historische categorieën als verieden en toekomst; wat voorbij is, doet zich namelijk structureel anders voor dan wat verwacht wordt. Koselleck gebruikt de metafoor ruimte niet om continue reeksen gebeurtenissen lukraak op te kunnen tellen, want de herinnering werkt noodgedwongen selectief en creëert een voorgeschiedenis met een slechts heel beperkte rationaliteit. Eerder geeft hij ermee aan hoe vanuit het heden het verleden als één geheel wordt ervaren, waarin vele lagen van eerdere tijden naast elkaar aanwezig kunnen zijn. Ten aanzien van de toekomst bedient Koselleck zich 
van de metafoor horizon om te laten zien hoe de toekomst voortdurend opschuift voor nieuwe ervaringsruimte. Hij illustreert dit met een anekdote over Chroesjtsjov, die in een toespraak beweerde dat aan de horizon het communisme reeds zichtbaar was. Een toehoorder vraagt dan: 'Kameraad Chroesjtsjov, wat is dat, horizon?' De leider raadt hem aan het in een woordenboek op te zoeken, waar de toehoorder het volgende vindt: 'Horizon, een schijnbare lijn die de hemel van de aarde scheidt en die zich verwijdert als men hem nadert.'

De verwachtingshorizon wordt slechts ten dele door de ervaring gestructureerd; gebeurtenissen hoeven niet te sporen met verwachtingen, al worden die verwachtingen natuurlijk sterk door de voorgeschiedenis uit de ervaringsruimte bepaald. Deze spanning tussen ervaring en verwachting roept in de moderne tijd een andere beleving van geschiedenis op. Mede door de hierboven genoemde aantasting van het christelijke eindtijdconcept schuift de verwachtingshorizon op en raakt de toekomst 'losser' van het verleden. Tegelijkertijd ligt een eventuele lotsverbetering echter minder snel 'aan gene zijde' en eerder 'in de tijd', een ervaring die zich in het opkomende gebruik van het begrip 'vooruitgang' manifesteert.

5. Tot slot wordt de nieuwe beleving van geschichtliche Zeit gekenmerkt door de veranderde pragmatische dimensie waarin historische en politiek relevante begrippen een rol gaan spelen. ${ }^{25}$ Veel van deze begrippen krijgen een ideologische lading, die het handelen met een beroep op toekomstperspectieven wil rechtvaardigen. In deze context ontstaan ook de zogenaamde '-ismen', nieuwe woorden als (in Duitsland) Republikanismus (voor het eerst bij Kant), Demokratismus (Schlegel) en later onder andere Liberalismus, Sozialismus en Kommunismus; dit zijn begrippen die allemaal een verhouding van toekomst en verleden in hun betekenis meedragen. Koselleck verheldert dit met de uit de Geschichtliche Grundbegriffe afkomstige observatie dat de conservatieven pas relatief laat in de negentiende eeuw, en aarzelend, onder het vaandel van Konservatismus gaan opereren om 'dem temporalen Zwangsraster und seinem Bewegungsdruck zu entgehen'. ${ }^{26}$ Veel begrippen beginnen van betekenis te 


\section{Steeds mooier}

veranderen en worden 'vertijdelijkt'; concepten als 'revolutie' en 'emancipatie' geven geen (geheel van) handelingen in een beperkte periode meer aan, maar worden vanaf het begin van de negentiende eeuw historische en politieke veranderingscategorieën met ideologische strekking.

Ook 'vooruitgang' krijgt als leus (Schlagwort) een morele en politieke strekking en wordt daarmee een appellerende, voorschrijvende handelingscategorie. Wie zijn eigen ideeën of handelingen in het historisch perspectief van vooruitgang situeert, voorziet ze daarmee immers van een goedkeurend stempel, dat de schijn van onvermijdelijkheid heeft. Het vooruitgangsetiket legitimeert handelen met een beroep op de loop van de geschiedenis.

Koselleck kent bij zijn beschrijving van de met geschichtliche Zeit samenhangende begrippen een grote rol toe aan dit collectieve enkelvoud 'vooruitgang'. Door het concept in samenhang met een aantal andere, nieuwe of van betekenis veranderde concepten in vergelijkbare contexten te bestuderen geeft hij een nauwkeurig beeld van de opkomst en het gebruik ervan tot ver in de negentiende eeuw. Kosellecks Kollektivsingular impliceert hier natuurlijk niet dat via een omweg een metafysisch vooruitgangsbegrip is binnengesmokkeld, dat verder onafhankelijk van zijn context kan worden beschouwd. Wel zal blijken dat bovengenoemde kenmerken hun betekenis bij vooruitgangsideeën tot op heden in vergaande mate zullen blijven behouden.

De winst van Kosellecks onderneming ligt in de historisch vruchtbare middenweg tussen het nominalisme van Skinner en het begripsrealisme van veel klassieke ideeënhistorici. In deze benadering wordt recht gedaan aan wat in intellectuele geschiedenis 'context' heet, of 'praktijk', of het geheel aan conventies, zonder dat historisch onderzoek volstrekt willekeurig wordt. Aan de ene kant is het nu mogelijk de klip van Scylla met haar hybride gedrocht te omzeilen en zodoende tot vergruizing leidende vormen van historisme en door te grote cesuren verminkend structuralisme te vermijden. Aan de andere kant valt tege- 
lijkertijd langs de draaikolk Charybdis met zijn spuwende reuzin te laveren, waarmee het gevaar van een al te globale en universele geschiedschrijving zonder empirische relevantie kan worden omzeild.

\section{Vooruitgangsbegrippen \\ en verwante veranderingscategorieën}

De koers is uitgezet voor een kleine geschiedenis van vooruitgangsbegrippen in de kunst, al zullen de twee volgende hoofdstukken niet als bij Foucault de 'korrel' van de gebeurtenissen tot het uiterste verkleinen, noch de wetsteksten en lexica van Koselleck uitpluizen. Wel wordt uit het werk van denkers, schrijvers, critici en kunstenaars hun opvatting van vooruitgang gedestilleerd. Maar eerst moet nog een ogenblik naar dat imposante vooruitgangsgeloof van de negentiende eeuw worden teruggekeerd. De manier waarop het woord 'vooruitgang' gebruikt wordt, verwijst namelijk tot op de dag van vandaag telkens weer naar dit conceptuele blok staal. In Duitsland was het begrip Fortschritt in deze tijd als 'politisches Schlagwort und als unbefragter, ubiquitärer Leitbegriff' alomtegenwoordig. ${ }^{27}$ Ook in de andere westerse landen werd het begrip te pas en te onpas gebruikt. De Victoriaanse Lady Carlisle liet zich vaak ontvallen dat wanneer iemand haar huis binnenkwam 'die niet in vooruitgang geloofde, hij meteen weer [kon] vertrekken'. ${ }^{28}$ Een dergelijke kwinkslag zou in ons tijdsgewricht aanzienlijk meer prikkelen, omdat men tegenwoordig meent het concept ver achter zich te hebben gelaten. In de negentiende eeuw waren vooruitgangsideeën weliswaar zo vanzelfsprekend geworden dat ze niet meer opvielen, maar de latere ontkenning van wat in de inleiding de hydra van de vooruitgang heette, stond nog in de kinderschoenen. Het begrip verdween, juist door zijn alomtegenwoordigheid, als lemma uit de lexica en diende als naam voor de meest uiteenlopende ondernemingen, van tijdschriften tot melkfabrieken op coöperatieve grondslag.

Uit het negentiende-eeuwse denken over vooruitgang blijkt hoezeer verwante historische categorieën als ontwikkeling en 
evolutie met dit begrip zijn gaan interfereren. Globaal gesproken heerste er een geloof dat veranderingen op de meest uiteenlopende terreinen, van industrie, moraal, techniek, wetenschap, politiek tot kunst, als een samenhangend proces moesten worden begrepen. ${ }^{29}$ Dit geloof dat alles geïnterpreteerd dient te worden als deel van een proces of ontwikkeling, is afkomstig uit twee verschillende culturele tradities die, enigszins gechargeerd, van de etiketten 'verlichting' en 'romantiek' kunnen worden voorzien.

De traditie van de verlichting wordt voortgezet in de overtuiging dat de werkelijkheid geheel gehoorzaamt aan wetten, of die nu processen van de natuur of ontwikkelingen in de menselijke beschaving betreffen. In tegenstelling tot bijvoorbeeld de metafysische principes van het Duitse idealisme was het beginsel van de Newtoniaan en materialist Saint-Simon een algemene uiterlijke wet van menselijke perfectibiliteit. Zijn aanvankelijke secretaris Auguste Comte werkte deze idee uit tot diens bekende, positivistische model met verschillende noodzakelijke stadia, volgens welke het beschavingspatroon van de hele mensheid zich ontwikkelt. Gebeurtenissen werden begrepen als elementen van een noodzakelijk proces, waarbij die noodzakelijkheid niet geheel vrij is van teleologische principes. Die principes zijn ook bij de wetmatigheden van Marx en Engels terug te vinden, hier echter op grond van hun hegeliaanse erfenis, waarin het finalisme veel duidelijker ligt opgesloten.

De traditie van de romantiek, beginnend met uiteenlopende denkers als Rousseau en Herder, zet zich tegen deze wetmatigheidsopvattingen af en gaat uit van een ontwikkelingsfactor als groei. Zo bedient Herder zich in zijn karakterisering van de geschiedenis van de boommetafoor om het 'organische' karakter van de menselijke geschiedenis als goddelijke immanentie te kunnen illustreren. Het woord Entwicklung gebruikt hij juist vanwege zulke biologische connotaties. Niettemin is het vaak synoniem met begrippen als Fortgang, Fortschreiten, Fortbildung en Progression. $3^{\circ}$

Nauw verweven met deze twee vormen van historicisme is het evolutiebegrip, dat ondanks zijn biologische herkomst een 
evaluatieve lading heeft. Ook Darwins concept van de survival of the fittest impliceert een progressieve ontwikkeling in de hele natuur met steeds meer waarde en schoonheid, getuige het befaamde slot van de Origin of Species:

Thus, from the war of nature, from famine and death the most exalted object which we are capable of conceiving, namely, the production of the higher animals, directly follows. There is grandeur in this view of life with its several powers, having been originally breathed by the Creator into a few forms or into one; and that, while this planet has gone circling on according to the fixed law of gravity, from so simple a beginning endless forms most beautiful and most wonderful have been, and are being evolved. 31

Waar het evolutiemodel op cultuurgeschiedenis wordt toegepast, klinkt het vooruitgangsbegrip doorgaans nog duidelijker mee, hetzij in het totale evolutionisme van iemand als Spencer, hetzij in het sociale evolutionisme van wetenschappers als Morgan en Tylor.

In deze familie van vooruitgangsbegrippen keren telkens drie elementen terug. Steeds wordt er een samenhangend proces beschreven waarin de relevante veranderingen globaal eenzelfde richting hebben en zich ook in de toekomst uitstrekken, waarin sprake is van een zekere cumulatie van verworvenheden en waarin bovendien een verbetering naar algemene maatstaven kan worden geconstateerd. ${ }^{32}$ Deze elementen zullen in de volgende hoofdstukken uitvoerig aan de orde komen.

Dat geldt ook voor het familielid 'modernisering', een begrip dat later veel gebruikt gaat worden en evenals het begrip 'modern' een rol van betekenis zal spelen in de beschrijving van historische processen. Het is opvallend dat het concept 'modern' in de negentiende eeuw vooral in een esthetische context figureert en dat uitdrukkingen als 'modern' en 'moderniteit' nog steeds een esthetische kernbetekenis hebben. 33 Het lijkt een vingerwijzing om niet langer te wachten met een geschiedenisvan vooruitgangsbegrippen in de kunst. 
PAR A LELLE DES ANCIENS

F. T DES MODERNES, OU IL EST TRAIT TE'

DE L'A STR O NO M IE, de la Giographie., de la Navigation, de la Guerre, de la Philolophie, de la Mufique, de la Medecine, \&'c.

CINQUIE'ME ET DERNIER DIALOGUE. Pat M. Perrault de l'Académie Françoife. TOME QUUATRIE'ME.

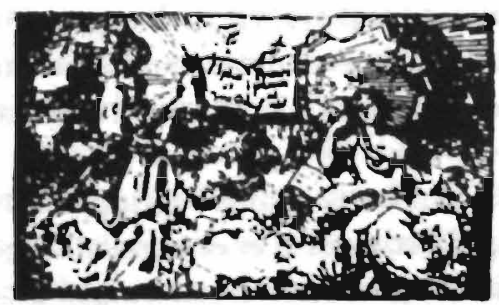

A PARIS,

Chez Jean Bartiste Coignard. Imprimeur ordinaire du Roy, \& de l'Acadenic Françuife, ruë $S$. J cques, à la Bible d'or.

M D CLXXXXVII.

AYLC PRIVILEGE DE SA BATESTE 


\section{Van klassieken en modernen: een opening naar de toekomst}

Wie zich met de geschiedenis van het denken bezighoudt, weerstaat vaak maar moeilijk de neiging om een begin of zelfs bet begin van een idee in de oudheid te zoeken. Dit bleek al uit het werk van Bury. Maar ook een meer eigentijds wetenschapper als Wellek probeert in een artikel over evolutie in de literatuur een aanvangspunt aan te wijzen bij Aristoteles, die hij aldus citeert:

From its early form tragedy was developed little by little as the authors added what presented itself to them. After going through many alterations, tragedy ceased to change, having come to its full natural stature. ${ }^{\mathrm{I}}$

Kort daarop relativeert hij dit beeld van Aristoteles als vroege literatuurhistoricus op evolutionaire grondslag, want tot aan de achttiende eeuw, aldus Wellek, was er van een systematische benadering van literatuurgeschiedenis helemaal geen sprake. Die relativering is natuurlijk terecht, want Aristoteles' opvatting over 'evolutie', door anderen minstens even inadequaat met 'ontwikkeling' en 'vooruitgang' gekarakteriseerd, ging over de aristotelische actualisering van de vorm, die al in potentie bestaat; niet over de geschiedenis van literatuur, die immers in zijn tijd nog niet als zodanig bestond. ${ }^{2}$ Het ontwikkelingsbegrip van Aristoteles heeft weinig van doen met noties over evolutie, ontwikkeling of vooruitgang zoals die in de achttiende en in de negentiende eeuw gingen leven.

Op een vergelijkbare manier beweert een filosofisch lexicon, dat 'nach Aristoteles [...] Fortschritt wesentlich zu den Künsten [gehört]', maar de passage waarop een beroep wordt gedaan 
zegt niet veel meer dan dat je eigenschappen in kunt vullen, zoals je een schets uit kunt werken. ${ }^{3}$ Zulke voorbeelden geven nog eens aan dat de historische en empirische relevantie van zulk realisme nihil is. Voor wie erachter wil komen welke vooruitgangsnoties in en over kunst een rol hebben gespeeld in het verleden, is echter ook een nominalistische of consequent historistische invalshoek te arm, zoals het vorige hoofdstuk betoogde. Waar ligt het juiste midden, waar te beginnen? Zoals zal blijken verdient het aanbeveling, het peillood iets dieper in de geschiedenis te laten zakken dan de overgangstijd waarin volgens Koselleck een nieuw perspectief op het verleden ontstaat vanuit de idee van een geschichtliche Zeit. Maar ook weer niet al te diep, dus niet tot wat vaak als een eerste proeve van kunstgeschiedenis wordt genoemd, namelijk Vasari's beroemde Le vite de' più eccelenti architetti, pittori e scultori Italiani de Cimabue insino a' tempi nostri uit 1550. In dit werk wordt het leven en werk van een aantal kunstenaars weliswaar als een opgaande ontwikkeling beschreven - en daarom is het ook van belang maar Vasari's studie is gebaseerd op zowel een finalistische als een cyclische tijdsopvatting. Met het hoogtepunt van deze ontwikkeling, het werk van Michelangelo, wordt de geschiedenis volgens Vasari opnieuw voltooid en heeft ze zich weer hersteld van haar terugval na de oudheid.

Een beter begin voor de geschiedenis van vooruitgangsbegrippen in de kunst is het eind van de zeventiende eeuw. Veel historici die de geschiedenis van het vooruitgangsbegrip hebben beschreven, besteden uitvoerig aandacht aan de al genoemde, in deze tijd spelende Querelle des Anciens et des Modernes, zij het meestal, zoals nog zal blijken, om verkeerde redenen. Vaak wordt de Querelle als cruciaal opgevat in een dergelijke ideeëngeschiedenis. Bijvoorbeeld door Bury of, meer recent, door P.B.M. Blaas, die met enig aplomb stelt dat hieruit 'de zogeheten idea of progress' voortkwam, die 'de mogelijkheid [bood] de geschiedenis "progressivistisch" uit te leggen'.4

Een aanleiding om hier met deze twist te beginnen is de omstandigheid dat juist de kunsten hier een centrale plaats innamen. Maar er zullen in het volgende meer redenen naar voren 
komen om juist op dit moment van de geschiedenis te beginnen. Wat was nu eigenlijk de inzet van dit, overigens pas in de negentiende eeuw dankzij de positivist en vooruitgangsprofeet $\mathrm{Au}$ guste Comte weer belangrijk geachte debat? En in hoeverre betoogden de Modernen nu inderdaad dat er sprake was van vooruitgang in de kunst?

\section{De Querelle des Anciens et des Modernes}

Deze discussie, die hoofdzakelijk in Frankrijk werd gevoerd, ging over de vraag, of de mens van dat moment zich kon meten met de illustere voorgangers uit de oudheid. Zo'n vraag heeft de bekoorlijke schijn van grote eenvoud, maar een eerste beschouwing van het debat laat al zien hoe complex dit probleem eigenlijk was.s

Meestal wordt het begin van de Querelle toegeschreven aan een bijeenkomst van de Académie Française op 27 januari 1687, die gewijd was aan Charles Perraults Poème sur le siècle de Louis le Grand, een lofzang op het eigen tijdsgewricht. Hij stelde hierin de schrijvers van zijn tijd op één lijn met de klassieken. Perrault, tegenwoordig eerder bekend als auteur van de Sprookjes van Moeder de Gans ( 1697 ), liet aan het begin van zijn gedicht weinig aan duidelijkheid te wensen over:

La belle Antiquité fut tonjours venerable, Mais je ne crus jamais qu'elle fust adorable.

Je voy les Anciens sans plier les genoux, Ils sont grands, il est vray, mais bommes comme nous. 6

Deze stellingname lokte kritiek uit van degenen die de Griekse en Romeinse literatuur niet alleen een voorbeeld ter navolging vonden, maar bovendien volmaakt en dus nooit te overtreffen. De gevierde dichter Boileau schijnt na voorlezing van Perraults Poème zelfs woedend te zijn opgesprongen, om uit te roepen dat het een schandaal was dat de Académie dit gedicht aan moest horen. 
Eigenlijk was deze discussie niet geheel nieuw. Zo speelde al enkele decennia de vraag, of christelijke thema's geschikt waren voor op de oudheid geïnspireerde heldendichten. Boileau zette zich af tegen een dergelijke, voor christelijk gebruik aangepaste klassieke mythologie, zoals die in Desmarets de Saint-Sorlins Clovis ou la France chrétienne uit 1657 kan worden aangetroffen. Deze tegenstelling bevatte reeds de kiem van een van de centrale twistpunten in de Querelle: de Modernen meenden dat de klassieken te overtreffen waren en stelden, althans aanvankelijk, dat op het christelijk geloof geïnspireerde poëzie boven literatuur gesteld moest worden die zich door heidense mythologie liet leiden. Hun tegenstanders, naast Boileau vooral La Fontaine en La Bruyère, verdedigden echter de hegemonie van de oudheid tegenover de aanspraken van de eigen tijd en tegen de in de traditie van de contrareformatie staande christelijke heroïek. Zo verweerde de beroemde fabeldichter La Fontaine zich tegen het door Perrault in zijn Poème sur le siècle de Louis le Grand uitgesproken verwijt van slaafse navolging. La Fontaine was eveneens aanwezig op die gedenkwaardige bijeenkomst van de Académie, maar in tegenstelling tot de cholerische reactie van Boileau (wellicht ook ingegeven door het feit dat Boileau door Perrault niet genoemd werd tussen de groten van hun eigen tijd), leek hij slechts te suffen. Een paar dagen later bood hij aan Huet, bisschop van Soissons, niettemin een épitre, een gedicht in briefvorm, aan, waarin de volgende regels, die representatief zijn voor de houding van degenen die het opnemen voor de Anciens:

On me verra toujours pratiquer cet usage:

Mon imitation n'est pas un esclavage.

Je ne prends que l'idée, et les tours, et les lois

Que nos maîtres suivaient eux-mêmes autrefois.

Over zijn eigen eeuw schreef hij:

Je le loue, et je sais qu'il n'est pas sans mérite;

Mais près de ces grands noms notre gloire est petite. 7 
Sommige historici traceren het begin van de Querelle reeds rond 1620 , toen Tassoni zich in Italië af ging zetten tegen de in de renaissance hooggeschatte Petrarca, tegen Aristoteles en ook tegen Homerus. Tassoni's Pensieri diversi werden in het Frans vertaald en hebben vermoedelijk Boisroberts aanval uit 1635 op Homerus beïnvloed, die een van de concrete doelwitten van de Modernen zou worden. ${ }^{8}$

In het verlengde daarvan beweerde Perrault in zijn Poème sur le siècle de Louis le Grand dat de zogenaamd onnavolgbare Homerus veel beter zou hebben geschreven als hij ten tijde van Lodewijk xiv had geleefd. Uit dit standpunt en andere uitlatingen van de Modernen spreekt groot zelfbewustzijn, het zelfvertrouwen van een cultuur die sterke expansie vertoont tegenover de afbrokkelende heerschappij van landen als Spanje en de Italiaanse staten. Waarom zouden het tijdperk en de cultuur van de Zonnekoning zich in hun grootsheid niet met die van keizer Augustus kunnen meten?

\section{Et l'on peut comparer sans craindre d'estre injuste, Le Siecle de Lonis an bean Siecle d'Anguste.9}

Een dergelijke poging deed Perrault in zijn omvangrijke werk Parallèle des Anciens et des Modernes (1688-1697). In de vorm van dialogen behandelt hij daarin uitvoerig de vorderingen op het gebied van de verschillende kunsten en van kennis. Nu worden volgens Perrault de mensen niet steeds slimmer of beter, evenmin als de leeuwen in Afrika inmiddels tammer zijn dan in de tijd van Alexander de Grote, maar de artistieke en cognitieve prestaties veranderen wel van gehalte omdat daarin op voorgangers voortgebouwd kan worden. Zo staan in de toneelstukken van tijdgenoot Corneille meer afgewogen en genuanceerde bespiegelingen over de menselijke hartstochten dan in die van de oudheid. En Molière is stukken levendiger dan Horatius, hij motiveert het handelen beter en heeft een ruimere blik, zoals een reiziger die bij Gibraltar ankomt niet meer denkt bij de zuilen van Herakles het einde van de wereld te aanschouwen, maar verdervaart. In de oudheid waren, om nog één voorbeeld 
van Perrault te noemen, de verworvenheden van de meerstemmige muziek ook nog volstrekt onbekend. ${ }^{\circ}$

In zijn Parallèle doet Perrault een indrukwekkende poging tot volledigheid. In vijf dialogen, die in vier afzonderlijke delen gedurende een periode van negen jaar verschenen, vergelijkt hij de prestaties van de oudheid met die van zijn eigen tijd op het gebied van de beeldende kunsten (architectuur, beeldhouwkunst en schilderkunst), van de welsprekendheid, van de literatuur ('la Poësie') en van de wetenschappen, of beter 'de l'Astronomie, de la Geographie, de la Navigation, de la Guerre, de la Philosophie, de la Musique, de la Medecine, etc.', zoals het in de inhoudsopgave heet. Daarbij komt de eigen tijd er keer op keer beter van af. Alleen - en niet onbelangrijk, zo zal nog blijken wordt er wel een uitzondering gemaakt voor Poësie en Eloquence, getuige het slot:

Nous conclurons, si vous l'avez agreable, que dans tous les Arts $\&$ dans toutes les sciences, à la reserve de l'Eloquence \& de la Poësie, les Modernes sont de beaucoup superieurs anx Anciens, comme je croy l'avoir prouvé suffisamment, Eq qu'à l'égard de l'Eloquence E de la Poësie, quoy-qu'il n'y ait aucune raison d'en juger autrement, il faut pour le bien de la paix ne rien decider sur cet article. ${ }^{11}$

Perrault had in zijn pleidooi voor de Modernen een medestander in Fontenelle, een fervent aanhanger van Descartes. Fontenelle beweerde in een invloedrijk pamflet, Digression sur les anciens et les modernes ( 1688 ), dat zijn eigen tijd nooit van minder allooi kon zijn, zoals de partijen van de Anciens meenden, omdat de natuur zich steeds van hetzelfde materiaal bedient, met dezelfde 'kracht'. In de eerste zin van zijn pamflet geeft hij het probleem beeldend weer:

Toute la question de la prééminence entre les anciens et les modernes étant une fois bien entendue, se réduit à savoir si les arbres qui étaient autrefois dans nos campagnes étaient plus grands que ceux d'aujourd'bui. ${ }^{12}$ 
Als de bomen sinds de oudheid niet veranderd zijn, zo voerde hij in dit fraaie staaltje van rationalistische bewijsvoering aan, waarom zouden de mensen dan wel verschillen? De klassieken hebben een aantal dingen ontdekt en uitgevonden omdat ze eerder leefden, niet omdat ze beter waren. Anders zou je hen net zo goed kunnen prijzen omdat ze als eersten uit onze rivieren hebben gedronken, en ons kunnen verwijten dat we slechts drinken wat daarvan over is. Au fond hebben mensen in verschillende tijden dezelfde mogelijkheden; er moet dan ook worden uitgegaan van een égalité naturelle. Wel geloofde Fontenelle, als vele zeventiende-eeuwers, dat het klimaat van invloed op de aard van een cultuur kon zijn, maar dit argument van zijn tegenstanders deed hem alleen verkondigen dat Lappen en negers zich wellicht de Griekse geest niet konden eigen maken. Daarentegen verschilden de gematigde streken van Griekenland, Italië en Frankrijk onderling klimatologisch te weinig om die égalité naturelle wezenlijk aan te tasten.

Toch aarzelde Fontenelle, evenals Perrault, bij de vraag of de literatuur uit zijn tijd die van de klassieken overtrof, een aarzeling die ook weer opduikt bij de Engelse pendant van de Querelle, welke in het laatste decennium van de zeventiende eeuw opbloeide onder invloed van de discussies in Frankrijk. Een van de belangrijkste vertegenwoordigers van de Britśe Modernen, Wotton, bleef ondanks zijn vertrouwen in de toegenomen kennis eveneens terughoudend met betrekking tot literatuur. ${ }^{13}$ De debatten in Engeland leverden weinig nieuwe gezichtspunten op en werden eerder gevoed door de Franse dan omgekeerd. Ook het fameuze The Battle of the Books, de satire op het redetwisten tussen Antients en Moderns van Jonathan Swift, geeft weinig argumenten en toont eerder aan hoezeer de vergelijking zelf tussen klassieken en tijdgenoten als een wedstrijd wordt opgevat, waarin de mogelijkheid van verschillende historische perspectieven niet werkelijk als een probleem wordt ervaren. ${ }^{14}$

In het relaas van $S$ wift komen op een vrijdag de geesten van de boeken in de St. James's Library tot leven om een vreselijke oor$\log$ uit te vechten. Virgilius, Lucanus, Homerus, Aesopuś en vele andere klassieken zien zich genoodzaakt het op te nemen 
tegen de (door Swift armzalig afgeschilderde) moderne schrijvers als Descartes, Hobbes en deelnemers an het debat als Bentley en Wotton. In het heetst van de strijd, die wel wat weg heeft van een knokpartij uit een goedkope western, staat hier Paracelsus tegenover Galenus, en Homerus tegenover Perrault en Fontenelle, die in Swifts ogen overigens weinig verweer hebben:

Then Homer slew W-sl-y with a kick of his Horse's heel; He took Perrault by mighty Force out of his Saddle, then hurl'd him at Fontenelle, with the same Blow dashing out both their Brains. ${ }^{15}$

In het latere stadium van de Querelle des Anciens et des Modernes flakkert de strijd over Homerus weer op, een worsteling die als gezegd al in de eerste helft van de zeventiende eeuw begonnen was. In 1714 publiceerde Houdar de La Motte als combattant van de Modernen een herdichting van de Ilias, voorafgegaan door een ode, 'Ombre d'Homère', waarin hij Homerus naar de aarde af laat dalen om La Motte tot diens onderneming uit te nodigen. Homerus verzoekt La Motte de Ilias te verbeteren, want:
Mon siècle eut des dieux trop bizarres,
Des héros d'orgueuil infectés,
Des rois indignement avares,
Défauts antrefois respectés. ${ }^{16}$

De woorden die La Motte Homerus in de mond legt, zijn een echo van wat onder andere Perrault in zijn Poème sur le siècle de Louis le Grand over Homerus had beweerd. In de na 1700 opbloeiende zogenoemde Querelle d'Homère krijgen de opvattingen van de Modernen in detail nog wel duidelijker gestalte, maar de belangrijkste inzichten en standpunten hebben zich dan al ontwikkeld. 
Aan het eind van zijn Digression sur les anciens et les modernes roept Fontenelle de traditionele metafoor in herinnering van het menselijk leven met zijn opeenvolgende stadia van zuigeling tot wijze grijsaard, een metafoor voor de steeds meer lerende mensheid. Die vergelijking gaat maar ten dele op, schrijft hij, want de mensheid kent in deze zin geen ouderdom:

\begin{abstract}
Zij zal altijd even goed in staat blijven tot datgene, waartoe ze ook in haar jeugd in staat was; en voortdurend meer tot die dingen die bij de leeftijd van een volwassen man horen. Dat wil zeggen, om de metafoor [l'allégorie] los te laten, dat de mensen nooit zullen degenereren en dat de weldadige inzichten van alle grote geesten, die achtereenvolgens naar voren zijn gekomen, zich steeds meer zullen ophopen. ${ }^{17}$
\end{abstract}

De levensloopmetafoor was in 1620 al ter discussie gesteld door Francis Bacon in zijn Novum Organum. De Ouden lijken wel ouder omdat ze onze voorvaderen zijn, maar tegelijkertijd zijn de latere generaties ouder, omdat ze meer ervaring hebben en meer hebben geleerd. ${ }^{18}$ In dat laatste geval impliceert de metafoor ook het verval en de degeneratie van de ouderdom en daartegen verzet zich Fontenelle, die getuige de aangehaalde passage het perspectief biedt van een open toekomst, waarin kennis gestadig groeit.

In de geschiedschrijving van vooruitgangsbegrippen krijgen dergelijke passages een groter gewicht dan ze in de context van de toenmalige discussies hadden. Daarom verbazen begripsrealisten als Bury ziç er ook over

that in this literary controversy the Moderns, even Fontenelle, seem curiously negligent of the import of the theory which they were propounding of the intellectual progress of man. ${ }^{19}$ 
Fontenelles expliciete breuk met de levensloopmetafoor is natuurlijk van belang, maar de Digression is toch in de eerste plaats een betoog over de waarde van de eigen tijd in vergelijking met de oudheid, eerder een battle of books dan een geschiedtheoretische verhandeling.

De meer recente opvattingen over de Querelle des Anciens et des Modernes relativeren het in de negentiende en in het begin van deze eeuw gevormde beeld van een periode waarin vooruitgangsideeën al bijna volledig gestalte zouden hebben gekregen. Het was ten tijde van de Querelle, zo had Auguste Comte beweerd, dat de 'idées de progrès nécessaire et continu' werkelijk een 'consistance philosophique' verkregen. In deze 'discussion solennelle' werd volgens hem voor het eerst in de universele geschiedenis van de menselijke rede de 'progrès fondamental' van die geschiedenis verkondigd. ${ }^{20}$

Dit vooruitgangsbeeld van Comte brokkelt echter geleidelijk af. In 1935 beschreef Paul Hazard in zijn standaardwerk over het begin van de verlichting, La crise de la conscience européenne $1680-171$, dat overigens relatief weinig aandacht aan de Querelle besteedt hoewel die precies in de door hem behandelde periode valt (en zich bovendien nog hoofdzakelijk in Frankrijk afspeelt), hoe juist het heden in die tijd centraal komt te staan. Men ontdoet zich eind zeventiende eeuw op allerlei manieren van een verleden dat al te lang als voorbeeld had gediend. ${ }^{21}$ De preoccupatie met een veranderende houding jegens de geschiedenis is in die zin niet alleen aan de Modernen, maar evenzeer juist aan de Anciens, de verdedigers van de oudheid, toe te schrijven. Enigszins gechargeerd zou je kunnen beweren dat bij sommige Modernen (waaronder niet Fontenelle) de geschiedenis niet begon maar juist ophield, omdat ze hun eigen tijd als een soort eindstadium zagen, waarin allerlei verworvenheden uit het verleden voor het grijpen lagen zonder dat de toekomst nieuwe perspectieven bood. In die zin zou je ze zelfs als de postmodernen van hun tijd kunnen bestempelen.

De verhouding tussen Anciens en Modernen is met betrekking tot vooruitgangsideeën vaak paradoxaal. Zo beweren aanvankelijk de Modernen dat de mens in de loop van de tijd in 
wezen hetzelfde blijft, terwijl in een later stadium van de Querelle juist de Anciens van dit argument gebruik maken om te laten zien hoe groot de verdiensten van de oudheid waren. Zo onderschrijven in dit latere stadium de Anciens het in het begin door de Modernen aangehangen standpunt, dat esthetische kwaliteiten aan een bepaalde tijd gerelateerd moeten worden, een opvatting van het verleden die buitengewoon 'modern' is. En zo is het ook paradoxaal dat de belangrijkste vertegenwoordigers van de Anciens, La Fontaine en Boileau, eigenlijk 'modern' waren; want Perrault had juist kunnen laten zien dat de eigen tijd beter werk opleverde dan de oudheid aan de hand van de literaire prestaties van deze twee Anciens.

Tal van dergelijke nuanceringen zijn te vinden in het knappe opstel van H.R. Jauß, dat als inleiding bij de historisch-kritische facsimile-uitgave van Perraults Parallèle verscheen, 'Ästhetische Normen und geschichtliche Reflexion in der "Querelle des Anciens et des Modernes"'.22 Jauß rekent hierin af met de mythe dat de Modernen vorm hebben gegeven aan een nieuwe manier om over geschiedenis te denken doordat ze verleden, heden en toekomst in een perspectief van vooruitgang begonnen op te vatten. Hij verdedigt dat door het debat als geheel en door de wederzijdse argumentaties een andere opvatting van geschiedenis begint te ontstaan, die hij voorts eerder uit ziet monden in het historische discours van de romantiek dan dat hij die opvatting als het begin van een negentiende-eeuws positivisme en evolutionisme interpreteert, wat in de geschiedschrijving van vooruitgangsideeën gebruikelijk is. In zijn benadering is daarnaast ook meer aandacht voor de esthetische dimensie van de Querelle.

De Modernen, aldus Jauß, blijven evenals de Anciens hoofdzakelijk binnen de grenzen van een humanistisch volmaaktheidsideaal, dat op gespannen voet staat met latere vooruitgangsideeën. Volmaaktheid (perfection) is namelijk een statisch concept dat onafhankelijk van de historische context wordt begrepen en een open toekomst met variabele mogelijkheden uitsluit. Kunsten en wetenschappen bereiken in dit perspectief ooit een hoogtepunt, waarop de volmaaktheid is bereikt, zodat 
verdere vervolmaking niet meer mogelijk is. Daarom kun je bij de Modernen ook nog niet spreken van wat Koselleck een decennium na Jauß geschichtliche Zeit zou noemen. Want in de historische tijdsbeleving van de deelnemers aan de Querelle is, om Kosellecks terminologie te hanteren, nog geen sprake van een onderscheid tussen ervaringsruimte en verwachtingshorizon, noch van een lineaire tijdsopvatting met een open toekomst. ${ }^{23}$

Het volmaaktheidsideaal staat volgens Jauß bij zowel de Anciens als bij de Modernen centraal; ze verschillen alleen van mening over het tijdstip waarop de volmaaktheid vorm heeft gekregen. Volgens de Anciens was dat reeds in de oudheid, volgens de Modernen eerder aan het einde van de (hun) geschiedenis, in het tijdperk van de Zonnekoning. Beider denkcategorie is dezelfde, alleen zijn vanuit die categorie verschillende hoogtepunten te zien. (Jauß spreekt hier met fraai-Duitse gewichtigheid van een Zweigipfligkeit der Weltgeschichte.)

Nieuw in de geschiedschrijving van de Querelle is Jauß' observatie dat in de verschillende debatten langzamerhand een verschuiving plaatsvindt van imitatio naar inventio, van de idee dat de volmaaktheid slechts bereikt kan worden door navolging van een absoluut gesteld, al dan niet verwezenlijkt ideaal naar de opvatting dat met behulp van de verbeelding nieuwe dingen geschapen kunnen en moeten worden. Reeds de genoemde Desmarets de Saint-Sorlin werkt het onderscheid uit tussen de copiste en de inventeur, die hij vergelijkt met degenen die hun water alleen maar uit de dorpspomp komen halen tegenover degenen die thuis een eigen bron hebben. Zijn waardering voor creativiteit ligt in het verlengde van zijn bewondering voor de scheppingskracht van God, die immers voor al het bestaande verantwoordelijk is door juist die scheppende activiteit.

Het belang van de verschuiving naar inventio wordt geillustreerd in Perraults Parallèle, waarin een van de gesprekspartners het volmaaktheidsideaal doorbreekt door zich tegen de idee te verzetten dat volmaaktheid slechts in de nabootsing van een absoluut ideaal kan worden bereikt, en door te stellen dat de criteria voor volmaaktheid van tijdsomstandigheden, namelijk 
de op een bepaald ogenblik heersende bon goût, afhangen. ${ }^{24} \mathrm{Zo}$ is ook het schoonheidsideaal van de oudheid niet absoluut en onveranderlijk. Ten dele bevat dit ideaal weliswaar universele elementen, waar het bijvoorbeeld om bepaalde verhoudingen gaat, of om door de natuur voorgeschreven functionele principes in de architectuur; die zijn 'de tout les gousts, de tous les pays et de tous les temps'.25 Maar het schoonheidsideaal is voor een aanmerkelijk deel ook betrekkelijk, het hangt af van smaak en gewoontes. Kenden de klassieken ook niet reeds verschil tussen Ionische, Dorische en Corinthische stijlprincipes bij het bouwen? En hoeveel vormen van welsprekendheid zijn er niet an te treffen in de oudheid! Met dergelijke nuanceringen ontwikkelt Perrault in zijn Parallèle een onderscheid tussen een 'beau relatif' en 'beautez universelles et absoluës'.

Jauß onderstreept het gewicht van het nieuwe concept van dat beau relatif en beschrijft hoe dit concept samenhangt met veranderende gedachten over creativiteit en fantasie. Als schoonheid immers niet (uitsluitend) aan een absoluut en eeuwig ideaal is ontleend, moeten er nieuwe waarden geschapen worden. Imitatio ruimt geleidelijk het veld voor inventio, een verandering die cruciaal is voor latere opvattingen in en over kunst. ${ }^{26}$

Dit afscheid van de dorpspomp ten gunste van het aanboren van eigen bronnen heeft namelijk verstrekkende gevolgen gehad. Allereerst werd het mogelijk te breken met een knellend geheel aan starre regels, die het classicisme een steriel aanzien begonnen te geven. Zo werd Abbé Dubos in zijn Réflexions critiques sur la poésie et la peinture (1719) woordvoerder van een aantal kunstenaars, dat het ver doorgevoerde rationalisme en een tot in de puntjes voorgeschreven academische stijl een belemmering vond en zich ook niet meer wilde beperken tot het nabootsen van genieën. ${ }^{27}$ Maar belangrijker is het dat de rol van de verbeeldingskracht de kunsten een eigen karakter bezorgde. Voor zover het inventio-ideaal een appel op de fantasie ging doen, ontstond een onderscheid met wetenschap en ambachten. Dit markeert het uiteenvallen van de traditionele samenhang van de artes liberales en de in de achttiende eeuw opkomende ruimte voor verschillende autonome domeinen. Pas vanaf deze 
tijd begint kunst zich als een zelfstandig verschijnsel te manifesteren, waarin naast schoonheid creativiteit een centrale categorie gaat worden. Dit ontstaan van het esthetisch domein aan het eind van de achttiende eeuw komt tot uiting in het gebruik van het enkelvoud 'kunst', dat bijna het karakter van een collectief enkelvoud in de zin van Koselleck aanneemt, al is het dan geen historisch concept.

Voor het perspectief op de geschiedenis ten slotte is het nieuwe principe van inventio niet minder revolutionair: de toekomst krijgt door de mogelijkheid om steeds nieuwe dingen te bedenken en uit te proberen een principieel open karakter. Deze gedachte laat zich niet goed meer verenigen met een finalistische geschiedopvatting en zo ontstaat ruimte voor het formuleren van vooruitgangsideeën. Enerzijds creëert de achttiende eeuw een omvangrijk verleden dat empirisch onderzocht, beschreven en geclassificeerd wordt in een explosief toenemende historische activiteit, anderzijds komt daar nu plotseling een toekomst bij vol onzekere contouren, een toekomst die ertoe uitnodigt zelf vorm te gaan geven aan de geschiedenis.

Uit het bovenstaande blijkt dat Jauß in zijn beschouwing over de Querelle precies de vruchtbare tussenweg bewandelt waar eerder een pleidooi voor is gehouden. Hij heeft aandacht voor een nauwkeurig beschreven historische context zonder in een historistische doodlopende straat te belanden, die het uitzicht tot de heel nabije omgeving beperkt en langduriger ontwikkelingen uit het oog doet verliezen. Zijn opstel laat zien dat het onmogelijk is om zoiets als 'de vooruitgangsidee' uit de schermutselingen van de Querelle te destilleren, omdat de geschiedenis complexer is dan het monolithische begrip 'vooruitgang' suggereert. Het is om te beginnen nogal geforceerd de Modernen als pleitbezorgers van een dergelijke idee te interpreteren. En voor zover het veranderende denken over het verloop van de geschiedenis verband houdt met de in de achttiende eeuw opkomende vooruitgangsideeën, kunnen deze veranderingen beter in een ruimere context worden beschreven. Met behulp van Jauß en Kosellecks opvattingen over het vooruitgangsbegrip wordt duidelijk dat van een geschichtliche Zeit in de Querelle 
nog geen sprake is. Jauß' analyse impliceert dat hier zowel een lineaire tijdsopvatting met een open toekomst als een onderscheid tussen ervaringsruimte en verwachtingshorizon ontbreekt. Tegelijkertijd haalt hij uit de Querelle die elementen naar voren die een nieuwe historische ervaring vorm zullen geven, namelijk het relativeren van absolute waarden in de context van de eigen tijd en een geloof in menselijke scheppingskracht dat de structuur van de toekomst voorgoed zal veranderen.

De beschrijving van Jauß laat verder zien dat in en door de Querelle zich langzamerhand een scheiding begint af te tekenen tussen het domein van wetenschappen en dat van kunsten. Bijvoorbeeld door Fontenelles indeling tussen choses d'imagination en de méthode de raisonner, maar vooral ook door de groeiende aandacht voor een beau relatif dat, in samenhang met de idee dat 'kunst' gecreëerd moet worden omdat imitatie van een absoluut ideaal niet meer voldoet, de kiem vormt van het esthetisch domein dat aan het eind van de achttiende eeuw gestalte krijgt.

De differentiatie tussen een esthetisch en een cognitief domein, en daarmee tussen ongelijksoortige ontwikkelingen in kunst en wetenschap, is een manifestatie van wat Koselleck de gelijktijdigheid van het ongelijktijdige noemde: de ervaring dat gelijke ontwikkelingen in verschillend tempo plaatsvinden. ${ }^{28}$ Deze dynamiek zal het denken over vooruitgang beheersen, evenals de spanning tussen als ongelijktijdig ervaren ontwikkelingen van morele en cognitieve aard en in die zin is de geschiedenis van de Querelle voor het ontstaan van moderne vooruitgangsideeën niet van relevantie ontbloot.

\section{Volmaaktheid en vervolmaking}

Het historisch vertoog van de deelnemers aan de Querelle des Anciens et des Modernes beweegt zich dus nog hoofdzakelijk binnen de grenzen van een volmaaktheidsideaal, dat al naar gelang de omstandigheden en het onderwerp van discussie inhoudelijk kan verschillen, maar dat in zoverre gelijk blijft dat het 


\section{Steeds mooier}

een open toekomst uitsluit. Of het ideaal nu verwezenlijkt is, geëvenaard kan worden of zelfs in een nabije toekomst ligt, de aard van het ideaal is statisch omdat het beantwoordt aan contemporaine criteria, die als onveranderlijk gegeven worden opgevat. Wie zich dit realiseert, vraagt zich af in hoeverre eigenlijk 'de vooruitgangsgedachte' in de achttiende eeuw tot 'volle ontplooiing' komt.

Bij een voor de achttiende eeuw belangrijk historicus als Voltaire staat het denken over de geschiedenis bijvoorbeeld nog hoofdzakelijk in het teken van cyclische theorieën. Weliswaar stelt hij dat de laatste van de vier periodes van bloei die het verleden heeft gekend, het tijdperk van Lodewijk xIv, iets van de vorige drie periodes heeft opgestoken en dat in dit tijdperk 'la raison humaine en général s'est perfectionnée', maar hij overschrijdt niet echt de grenzen van een statisch volmaaktheidsideaal, getuige bijvoorbeeld het begin van zijn Le siècle de Louis XIV, waarin hij schrijft:

In deze vier gelukzalige periodes zijn de kunsten vervolmaakt en ze zijn, in hun dienstigheid aan een tijdperk voor bet schitteren van de menselijke geest, het nageslacht tot voorbeeld. 29

Verschillende verworvenheden van de geest en van het menselijk vernuft (les arts) hebben hun voltooiing in een periode van bloei bereikt en dienen voortaan als voorbeeld voor latere generaties, net zoals de oudheid volgens de Anciens het nageslacht de ideale norm voor volmaaktheid voorschotelde.

Het is ondoenlijk in het kort een enigszins representatief beeld te schetsen van de veelheid aan gedachten die in de loop van de achttiende eeuw over de ontwikkeling en eventuele vooruitgang in de kunsten ontstaat, ook als wordt afgezien van al die geschriften die sceptisch of afwijzend staan tegenover een allesomvattende ontwikkeling van de cultuur, zoals Rousseaus Discours sur les sciences et les arts uit 1750 . Hier is van belang dat parallel aan het ontstaan van een esthetisch domein ook de geschiedschrijving van de kunsten een meer autonoom karakter 
krijgt. Zo publiceerde John Brown in 1763 een literatuurgeschiedenis (of geschiedenis van de poëzie; het verschil is tot in de achttiende eeuw nog niet zo eenvoudig aan te geven). A Dissertation on the Rise, Union and Power, the Progressions, Separations, and Corruptions of Poetry and Music beschrijft hoe de door hem veronderstelde oorspronkelijke eenheid van zang, dans en poëzie uiteenvalt door het ontstaan van nieuwe genres. Dit ontwikkelingsperspectief wordt door Brown echter als een terugval beschouwd, en hij bepleit dan ook een herstel van die oorspronkelijke eenheid in de kunst. ${ }^{30}$

Winckelmanns invloedrijke Geschichte der Kunst des Alterthums, dat een jaar later verscheen, biedt een vergelijkbare aanblik. We treffen er een ten dele op zichzelf staande ontwikkeling in de (beeldende) kunst in aan, maar evenals bij Brown wel met een geschiedopvatting die in het teken van een cyclische tijd staat. Want ook bij Winckelmann treedt verval op na het hoogtepunt in de oudheid van edle Einfalt en stille Größe, een hoogtepunt dat de eigentijdse kunst opnieuw dient na te streven.

Wanneer gelet wordt op de manier waarop de meeste denkers uit de verlichting de geschiedenis van de kunsten (in zoverre ze die überhaupt los zien van de ontwikkeling van wetenschappen en techniek) interpreteren, valt op dat nog bijna altijd van zo'n cyclisch beeld wordt uitgegaan, of van een finalistisch verloop. In het eerste geval laat men periodes langzamerhand opkomen, bloeien en weer in verval raken. In het tweede geval loopt een (meestal lineair geïnterpreteerde) geschiedenis uit op een tijdperk dat ophanden is of zelfs reeds is aangebroken en dat dan omschreven wordt als een noodzakelijk of logisch eindpunt van een aantal ontwikkelingen of stadia.

Een opening naar de toekomst in een lineair, onbegrensd tijdsbeeld komt in de achttiende eeuw nauwelijks voor, hoezeer de inventio-gedachte en de differentiatie tussen wetenschap, kunst en techniek en de daarmee opkomende gelijktijdigheid van het ongelijktijdige het cyclische en finalistische model ook beginnen aan te tasten. Een dergelijke instabiliteit valt bijvoorbeeld te bespeuren bij de (destijds marginaal blijvende) cyclische geschiedopvatting van Giambattista Vico (I668-1744), te- 
genwoordig vaak de vader van de moderne geschiedenis genoemd. Zijn nieuwe wetenschap (Principi di una scienza nuova d'interno alla commune natura delle Nazioni, 1725) onderscheidde een in verschillende periodes te verdelen voortgang in de geschiedenis. Vico beklemtoonde echter, en daarin was hij 'modern', dat de mens zelf deze geschiedenis vorm gaf. Dit creatieve beginsel staat op gespannen voet met zijn verder cyclische beschrijving van verschillende tijdperken en met zijn gehandhaafde vertrouwen op de Voorzienigheid.

Een enigszins vergelijkbare, zowel finalistische als cyclische benadering van het verleden is aan te treffen in het werk van de voor het periodedenken van Comte zo invloedrijke econoom, encyclopedist en staatsman Turgot (1727-1781), die de wereld langzaam maar zeker beter ziet worden, maar die daarin tegelijkertijd een cyclisch patroon blijft zien. Ook in Herders Ideen zur Philosophie der Geschichte der Menschbeit (1784-179I) valt een dergelijke ambivalentie van geschiedopvattingen aan te wijzen, met cyclische en finalistische elementen en een opkomende neiging om de toekomst open te breken.

Ondanks deze tendenties manifesteert zich kort na 1800 in Duitsland een culminatie van finalistisch denken, die tegelijk het begin van een geschiedopvatting zal blijken te zijn die tot ver in de twintigste eeuw haar invloed doet gelden. Dat is de filosofie van Hegel. Kunst is, althans voor de latere Hegel, de manier waarop 'de absolute geest' zichzelf in volledige vrijheid aanschouwt. Hij onderscheidt in de ontwikkeling van de kunsten drie verschillende stadia, die niet louter historisch zijn in de empirische zin van het woord en minstens evenzeer betekenis ontlenen aan de plaats die zij hebben in Hegels dialectisch bouwwerk. In het eerste stadium, dat van de symbolische kunst, waarbij aan vroeg-oriëntaalse culturen moet worden gedacht, wordt de Idee van de absolute geest wel vermoed maar nog niet adequaat uitgedrukt. In klassieke kunst echter vallen vorm en stof, Idee en verschijning geheel en al samen, terwijl in romantische kunst de Idee en de 'Innerlichkeit des Gemüths' zodanig overheersen dat een nieuw stadium aanbreekt waarin de kunst als zodanig wordt 'aufgeheben', dus geëlimineerd én op een hoger niveau gebracht. ${ }^{3}$ ' 
In het denken van Hegel is de ontwikkeling van de kunst een uitdrukking van een meeromvattende dialectische ontwikkeling. Hiermee begint de later steeds belangrijker wordende opvatting gestalte te krijgen dat kunst een uitdrukking van de eigen tijd is, en dat ook moet zijn omdat men de tijdgeest niet kan ontlopen. Wie een dieper inzicht krijgt - of denkt te hebben - van de ontwikkeling van de eigen cultuur, kan op grond daarvan constateren dat sommige kunst heeft afgedaan, dat wil zeggen niet meer van deze tijd is.

Het is niet mogelijk Hegels esthetische theorie in zo weinig woorden recht te doen en dat is ook niet de bedoeling. Hier wordt volstaan met de vaststelling dat het befaamde probleem van 'het einde van de geschiedenis' zich bij hem ook ten aanzien van de kunsten voordoet. Hans-Georg Gadamer schetst beide problemen in elkaars verlengde: de geschiedenis is bij Hegel niet afgelopen, zo stelt hij, maar zij verloopt niet meer 'als ein Fortschritt im Sinne des Bewußtseins der Freiheit' en kan wellicht helemaal niet meer als vooruitgang worden gezien. Evenzo houdt ook de geschiedenis van de kunst niet op, maar in haar laatste, romantische stadium voldoet zij niet meer aan 'das höchste Bedürfnis des Geistes', en wordt zij opgenomen in godsdienst en filosofie. ${ }^{32}$ Hoe men zich deze 'Auflösung der romantischen Kunstform' ook voor wil stellen, de finalistische tendens van dit denken verhindert uiteindelijk een verdere ontplooiing van de kunsten in de toekomst. Zolang er niet aan het voortbestaan van de kunsten zelf getwijfeld wordt, zouden ze moeten blijven steken in een 'hegeliaans classicisme'. Niet voor niets vraagt Gadamer zich in zijn artikel over Hegels esthetica af, hoe latere ontwikkelingen door Hegel geïnterpreteerd zouden worden. 'Indessen,' zo constateert hij, 'das Ende der Kunst wird sich so nicht vorschreiben lassen.' 33

Hegels dialectiek richt zich au fond onafgebroken op vervolmaking, waarbij een welomschreven eindpunt van volmaaktheid de uitkomst is van het totale historische proces. Op het eerste gezicht lijkt dat ook op te gaan voor de manier waarop de grootste vooruitgangsapostel van de achttiende eeuw, de al ter sprake gekomen Markies de Condorcet, de geschiedenis van de 
mensheid beschrijft. In zijn optimistisch getoonzette Esquisse d'un tableau historique des progrès de l'esprit humain (1795) onderscheidt Condorcet tien periodes.34 Deze vormen een allesomvattende wereldgeschiedenis, die noodzakelijk, en - ondanks plaatselijke en tijdelijke terugval - continu, een steeds grotere volmaaktheid voor de mensheid impliceert. De Esquisse beschrijft deze vooruitgang (les progrès) chronologisch, van landbouwkundige verbeteringen tot de uitvinding van de boekdrukkunst, wetenschappelijke ontdekkingen en toenemende politieke vrijheid. Al deze verworvenheden worden als een optelsom van individuele prestaties beschouwd, zoals Condorcet in het begin van zijn boek beweert, waar hij bij uitzondering het woord progrès als collectief enkelvoud gebruikt:

Deze vooruitgang [ce progrès] is aan dezelfde algemene wetten onderworpen als die te zien zijn in de individuele ontwikkeling van onze vermogens [facultés], aangezien bij de uitkomst is van deze ontwikkeling, die zich aldus bezien gelijktijdig voordoet onder een groot aantal in maatschappijen verenigde individuen. 35

Het finalisme is bij Condorcet weliswaar niet geheel afwezig, maar in vergelijking met het hegeliaanse denken weinig prominent. Hier gat ontegenzeggelijk een deur naar de toekomst open. Ten eerste situeert Condorcet zijn laatste periode expliciet in een tijd die nog komen moet. En hoewel hij relatief uitvoerig beschrijft hoe die eruit zal zien, heeft die beschrijving al grotendeels het karakter van een programma dat in de pragmatische, politiek getinte context functioneert die Koselleck als een karaktertrek van de nieuwe tijdsbeleving heeft geschetst. Condorcet beschrijft niet alleen hoe de toekomst eruit zal zien, hij beschrijft daarmee ook hoe de toekomst eruit moet zien. Ten tweede zijn Condorcets ideaalbeelden dynamisch, in tegenstelling tot de doelgerichte systematiek bij Hegel, waarin sprake is van een metafysische ontplooing van de Geest die tot zichzelf terug moet keren. Condorcet spreekt vaker van perfectionnement dan van perfection. De menselijke soort is volgens Con- 
dorcet te verbeteren; hij gebruikt de door Rousseau in omloop gebrachte, met een moreel appel geladen term perfectibilité, een vervolmaakbaarheid die volgens hem onbepaald (en dus onbegrensd) is, een perfectibilité indéfinie. ${ }^{36}$

Condorcet besteedt in de Esquisse weinig aandacht aan de kunsten, maar dat ze vooruitgaan zoals alles vooruitgaat, is voor hem onbetwist. Bij de Grieken lijken de schone kunsten hun volmaaktheid te hebben bereikt, schrijft hij in een impliciet commentaar op de Querelle, maar er valt meer over te zeggen door het

waardevolle genie van de kunstenaar [heureux génie de l'artiste]; een uitzonderlijkheid [distinction] die erin slaagt de nauw afgebakende wegen te doen verdwijnen waarop men de vervolmaking van de schone kunsten heeft teruggedrongen. 37

Dergelijke zinsneden illustreren het belang van de inventio als een concept dat de volmaaktheidsgedachte aan gaat tasten, die tijdens de Querelle nog een vrijwel vanzelfsprekend uitgangspunt was.

Condorcet noemt bij de Grieken slechts een paar schrijvers, op andere kunsten gaat hij daar niet in. Later haalt hij Boccaccio's Decamerone als getuigenis aan van een toenemende vrijheid van denken, wat vermoedelijk op het amoureuze gehalte van het boek slaat, en Petrarca, Dante en weer Boccaccio als vervolmakers van de Italiaanse taal, die bovendien esthetisch genot brengen..$^{8}$ Pas aan het eind van zijn schets, in de beschrijving van de negende en tiende periode, wijdt hij enkele zinnen aan muziek, de tekenkunsten en weer de literatuur, waaronder theater. Dat de schilderkunst van zijn tijjd geen Rafaëls en Carracci's kent, maakt hem wat onzeker. Hij wijt dit echter niet aan het verval van die kunst - want dergelijke resultaten zijn immers door de mensheid verworven en worden aldus bewaard - maar, wat vrijblijvend misschien, aan 'politieke en zedelijke veranderingen'. Condorcet meent verder dat de kunsten vooruitgaan in samenhang met én door de vooruitgang in wetenschappelijke 
kennis, hoewel hij dat nauwelijks toelicht. 39 Hij beweegt zich überhaupt nogal ongemakkelijk op het nieuwe domein van de kunsten; in een alinea waarin hij de naar literaire maatstaven gemeten vervolmaking van diverse talen in verschillende tijden lokaliseert - een mooi voorbeeld van het door Koselleck beschreven principe van de gelijktijdigheid van het ongelijktijdige duikt weer het statische ideaal op van een 'goût juste et sûr' die voor de oudheid én voor zijn eigen tijd opgaat, een eeuwige standaard die op gespannen voet staat met zijn idee van een perfectibilité indéfinie. $4^{\circ}$

Deze spanning tussen de eeuwige en dus onveranderlijke schoonheid van het absolute en de in termen van vooruitgang begrepen verworvenheden van de eigen tijd, ontstaan tijdens de Querelle, scheurde de toekomst steeds meer open. Aanvankelijk probeerde men verschillen tussen klassieken en modernen in het verleden te overbruggen, maar door dergelijke pogingen veranderde de tijd zodanig van karakter dat het licht niet alleen op het verleden scheen, maar ook op de toekomst begon te vallen. Een centrale rol in deze discussies speelde, als gezegd, het toenemend belang dat aan de verbeeldingskracht werd gehecht. Het creatieve vermogen van de mens bracht een nieuwe verwachtingshorizon en stimuleerde als gevolg van discussies over vooruitgang bovendien het ontstaan van een onafhankelijk esthetisch domein. Dat betekent niet dat er op een gegeven moment zoiets als de idee van 'vooruitgang in de kunst' ontstond, maar dat vooruitgangsideeën en de identiteit van kunst gelijktijdig gestalte begonnen te krijgen.

De gespannen verhouding tussen op absolute waarden berustende eeuwige schoonheid en het veranderlijke, met zijn relatieve en vluchtige karakter, zou later bij Baudelaire bewust gethematiseerd worden. Het bewustzijn van die spanning wordt meestal beschreven als het begin van het 'moderne', zoals in de loop van het volgende hoofdstuk zal blijken. Maar eerst dienen enkele woorden aan de romantiek te worden besteed. 


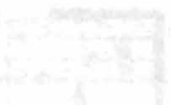




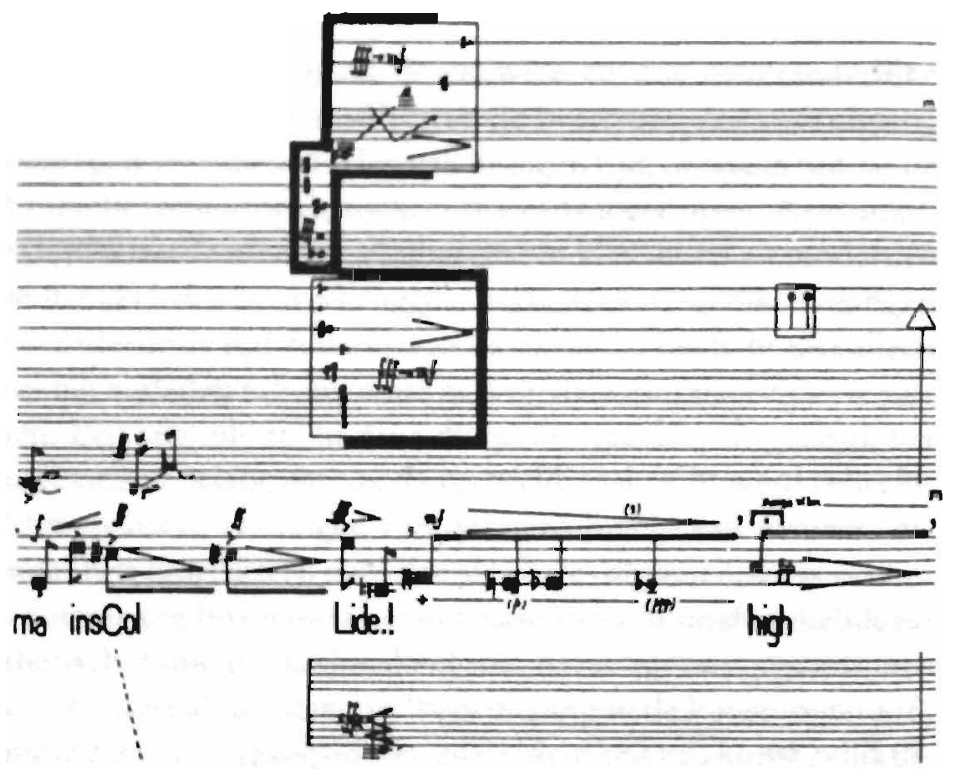

Fragment uit de partituur van Luciano Berio's 'Circles' 


\section{Van romantiek tot avant-garde}

In de achttiende eeuw ontstond een verleden, dat door talloze onderzoekers werd ontsloten en geclassificeerd. De empirische instelling van deze onderzoekers bracht een tot dan toe onvoorstelbare rijkdom aan gebruiken, voorvallen, rituelen, natuurverschijnselen en kunstvoorwerpen aan het licht. Voortaan had de mens een geschiedenis waar hij niet meer omheen kon.

Het verleden neemt in de romantiek dan ook een prominente plaats in. De romantische denkers moeten echter weinig hebben van historische schema's als die van Condorcet; een lineair en rationeel geordend verloop van de geschiedenis is wel het laatste waar ze waarde aan hechten. De romantiek ontwaart de rijkdom van het verleden eerder in het andere en het vreemde ervan dan in datgene wat voorspelbaar vooruitloopt op het hier en nu; eerder in een ver verwijderd tijdperk, de middeleeuwen bijvoorbeeld, of de oudheid, dan in de vermaledijde, prozaïsche verlichting die aan haar voorafgaat. Zulke afgelegen, op zichzelf staande periodes zijn meestal een manifestatie van de Gouden Tijd, die voorbij is maar waarin men terug kan keren met behulp van de verbeelding, zwervend als Novalis' Heinrich von Ofterdingen. Of het zijn hoogtepunten van de nationale geschiedenis, bloeiperiodes in de eigen cultuur: de Nederlandse romantiek schept haar Gouden Eeuw met Rembrandt en Frans Hals; in de Engelse romantiek wekt Walter Scott met zijn historische romans oude ridderidealen weer tot leven. Zulke tijdperken worden om zichzelfs wille bestudeerd, waarbij de heersende ideeën maar voor zichzelf moeten spreken, zoals Leopold von Ranke (1795-1886) betoogde, daarmee een historisme verkondigend dat sindsdien niet meer in de geschiedschrijving zou ontbreken. 
In de romantiek, kortom, bleek de gedachte aan een zich steeds verder en hoger ontwikkelende cultuur nauwelijks aan te slaan. En waar deze idee toch beleden werd, ontstonden de in het vorige hoofdstuk genoemde discrepanties en inconsequenties, zoals bij Friedrich Schlegel, die een oneindige historische vooruitgang postuleerde welke echter tegelijkertijd weer een cyclisch proces moest vertegenwoordigen. Een uitzondering op deze vaak onbewuste reserve jegens een open toekomst is misschien het werk van de romantische schrijver Adam Müller (1779-1829). In zijn Vorlesungen über deutsche Wissenschaft und Literatur ( 1806 ) verzette hij zich tegen de gedachte van een Gouden Tijdperk en tegen absolute schoonheidsidealen, waarvan de verlichting immers net afscheid had genomen. Volgens Müller was de verdienste van Duitse schrijvers vanaf Winckelmann tot Friedrich Schlegel, dat ze de geschiedenis van de kunst en van de literatuur als een samenhangend geheel waren gaan beschrijven, en niet als een opeenvolging van onafhankelijke, losse kunstwerken. Niettemin zag Schlegel de continuiteit van de literaire traditie over het hoofd. We moeten volgens Müller niet de grootste dichter: de Mensheid uit het oog verliezen, noch het grootste gedicht: de Geschiedenis. ${ }^{\prime}$

Dit verheven mensheidsideaal van de romantiek zou in de loop van de eeuw versmelten met een deels positivistisch, en vaak haast religieuze trekken aannemend geloof in vooruitgang, zoals Victor Hugo dat in La légende des siècles zou verkondigen. In dit omvangrijke, profetische heldendicht van de menselijke beschaving komt - net als in Condorcets Esquisse - ook de toekomst aan bod. Aan het eind wordt een twintigste eeuw voorspeld, vol goedheid, waarheid en schoonheid:

Où va-t-il, ce navire? Il va, de jour vêtu, A l'avenir divin et pur, à la vertu,

A la science qu'on voit luire, A la mort des fléaux, à l'oubli générenx, A l'abondance, au calme, an rire, à l'homme beureux;

Il va, ce glorieux navire, Au droit, à la raison, à la fraternité, 


\section{A la religieuse et sainte vérité}

Sans impostures et sans voiles,

A l'amour, sur les coeurs serrant son doux lien, An juste, au grand, au bon, au beau... - Vous voyez bien

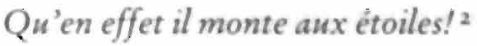

De tijdsbeleving van de Engelse en de Duitse romantiek mocht rond 1800 vooralsnog eerder cyclisch of finalistisch van karakter zijn dan lineair, er is één gebeurtenis die deze beleving destijds haar vanzelfsprekendheid ontnam. Dat was de Franse Revolutie, die een verpletterende indruk heeft gemaakt op vrijwel alle vooraanstaande romantici. Zowel de ideologische radicaliteit als het massale karakter van de gebeurtenissen in Frankrijk schokten het historisch besef: hier gebeurden dingen die de wereld voorgoed een ander aanzien gaven; hier manifesteerde zich de geschiedenis in een onomkeerbare vorm met een plotseling uiterst onzekere toekomst.

Het woord 'revolutie' krijgt in deze tijd een nieuwe betekenis: het wordt een historisch geladen veranderingsbegrip in de zin van Koselleck, een ideologische term. Sindsdien bevat het revolutiebegrip een explosieve paradox; het accentueert in deze nieuwe context zowel een absolute (en gewelddadige) breuk met de traditie, als een realisering van idealen die in feite een voortzetting zijn van wat voor die breuk de moeite waard werd geacht.

M.H. Abrams schetst dit gedurende de romantiek opkomende en voortaan zo invloedrijke idee van revolutie kernachtig aan de hand van zes kenmerken:

(1) de revolutie zal door middel van een even onontkoombare als louterende explosie van geweld en vernietiging de bestaande politieke, sociale en morele orde in absolute zin en vanaf haar grondvesten opnieuw vormgeven, en op die manier (2) plotseling, dan wel binnen een opmerkelijk korte tijdspanne de overgang tot stand brengen van het huidige tijdperk van diepgeworteld kwaad, van lijden en wanorde, naar een tijdperk van vrede, rechtvaardigheid en optimale 
omstandigheden voor algemeen geluk; (3) de revolutie zal worden aangevoerd door een militante elite die geconfronteerd zal worden met krachten die zich hebben toegelegd op bet in stand houden van het huidige kwaad [...]; (4) hoewel zij op een specifieke en kritieke tijd en plaats zal ontstaan, zal ze zich onuitroeibaar overal verspreiden, over de gehele mensheid; (s) haar zegeningen zullen heel lang hun vruchten afwerpen, misschien voor altijd, omdat de verandering in institutionele omstandigheden en bet culturele milieu van de mens zijn intellectuele en geestelijke ellende zal genezen [...]; (6) de revolutie ten slotte is onvermijdelijk, omdat ze gewaarborgd wordt door iets transcendents dan wel iets immanents en niet door onszelf, wat een onafwendbare zege garandeert voor totale rechtvaardigheid, gezamenlijkheid en geluk op aarde. ${ }^{3}$

Het revolutiedenken in deze vorm wordt pas aan het eind van de negentiende eeuw gemeengoed bij vernieuwingsbewegingen in de kunsst en het zal uiteindelijk in al zijn vitaliteit doorbreken bij de avant-garde, zoals we nog zullen zien. Het breukkarakter dat in de eerste drie van de genoemde kenmerken besloten ligt, komt dan op gespannen voet te staan met vooruitgangsideeën, die immers een zekere vorm van continuïteit veronderstellen.

Wellicht door deze aantasting van continuiteit in de geschiedenis en door de ontkenning of afwezigheid van een open toekomst, maar stellig ook door de reactie die volgde op de chaos en verwarring die het revolutiedenken overal provoceerde, lijkt het vooruitgangsconcept in de romantiek tijdelijk onder te duiken en gedurende enige tijd, om het in romantisch taaleigen uit te drukken, in het donker te rijpen. Wanneer het weer te voorschijn komt, heeft het revolutie in het bloed, en verheven mensheidsidealen. En wat misschien nog belangrijker is voor het terrein van de kunsten: de kracht van verbeelding, originaliteit en fantasie is door de invloed van de romantiek zo groot geworden, dat onbeperkte verandering en vernieuwing voortaan een vanzelfsprekendheid worden, die de toekomst openbreken. Het romantische adagium van het principieel onvoltooibare, 
het complement van deze lof der verbeeldingskracht, brengt die toekomst volop onder de aandacht: de mensheid en dus de kunstenaar hebben voortaan zicht op een niet te fixeren horizon.

\section{De negentiende eeuw: Comte en Spencer}

Ideeën over vooruitgang, ook in de kunst, kregen in de negentiende eeuw op eindeloos veel manieren gestalte. Het is niet de bedoeling hier al die manieren gedetailleerd in kaart te brengen; beter is het een satellietfoto te maken, waarbij gelet wordt op een onderscheid in argumentatietypen.

Van grote afstand bekeken vallen er dan in de negentiendeeeuwse veelvormigheid drie stroomgebieden te onderkennen.4 Allereerst is er een complexe delta van vooruitgangstheorieën die geënt zijn op het Duitse idealisme en de, grotendeels ook Duitse, romantiek. Als gezegd houden de meeste van deze theorieën meer of minder expliciet vast aan een bepaald volmaaktheidsideaal. Dat viel bij Hegel te bespeuren, en wat eerder al bij Herders bloeimetaforiek, die veel invloed kreeg op historische beschrijvingen van de cultuur in termen van organische ontwikkeling. Vele denkers en schrijvers projecteerden een a priori plan met omschreven doelen in de geschiedenis en ijkten deze doelen dan aan een periode uit het verleden (bij voorkeur de oudheid of de middeleeuwen). Deze delta hoort vanwege de finalistische en cyclische tijdsopvattingen niet tot het terrein van vooruitgangsideeën in engere zin, in tegenstelling tot de volgende twee stroomgebieden.

Het tweede bestaat uit een groep theorieën in het verlengde van Condorcets Esquisse, waarin het denken over geschiedenis een lineaire tijdsopvatting veronderstelt en in de context van een veel- of allesomvattende maatschappijtheorie figureert, in een 'sociologisch' perspectief. Dit doet zich voor bij filosofen als Saint-Simon, Karl Marx, John Stuart Mill, Auguste Comte en Hippolyte Taine. In deze, meestal positivistische, optiek wordt vooruitgang in de kunsten geïnterpreteerd als een nood- 
zakelijk bijverschijnsel van wetmatig verlopende maatschappelijke processen, dan wel als een produkt van sociaal-economische verandering. Of, zoals de vader van Virginia Woolf, de filosoof en essayist Leslie Stephen, het in 1876 voor de letteren samenvatte: 'Literature is the noise of the wheels of history.'s

In het derde gebied, dat in de tweede helft van de negentiende eeuw steeds belangrijker werd, stonden vooruitgangsideeën in het teken van het evolutiedenken, dat eveneens van een lineaire tijdsopvatting uitgaat. Het evolutiemodel leverde een alomvattend raamwerk voor de beschrijving van culturele processen voor Herbert Spencer en, aanvankelijk minder invloedrijk, voor Edward B. Tylor en Lewis H. Morgan. Ook de geschiedenis en de ontwikkeling van de kunsten werden teruggevoerd op een van oorsprong biologisch evolutiemodel, dat een verklaring wil bieden voor het geleidelijk ontstaan van steeds nieuwe soorten en het bereiken van een steeds hoger niveau. In dit geval is vooruitgang in de kunsten geen bijprodukt van maatschappelijke processen, maar deel van een meer algemene, absolute wetmatigheid waar ook die maatschappelijke processen onder ressorteren.

Voor het tweede stroomgebied zijn de gedachten van Auguste Comte een goede illustratie. Comte bracht, zoals bekend, drie verschillende stadia in het geheel van maatschappelijke processen aan. Volgens hem ontstonden de kunsten al in de primitieve oorsprong van het eerste, theologische stadium, namelijk in het zogenaamde fetisjisme (ook wel animisme): het geloof dat alles bezield was, moest immers een groot beroep doen op het voorstellingsvermogen. Ook de verdere ontwikkeling van dit theologische stadium, het polytheïsme, droeg volgens Comte aan het ontstaan van de kunsten bij, alleen al omdat de vele goden luisterrijk 'aangekleed' en creatief aanbeden dienden te worden. In de laatste periode van dit stadium, het monotheïsme, is van een voorlopig hoogtepunt sprake. Comte illustreert dat met de literatuur van Shakespeare, Corneille en Molière, met het dan heersende ideaal van harmonie, met de uitvinding van nieuwe instrumenten in de muziek, met de schilderijen van Rafaël, enzovoort. 
In het metafysische stadium worden de gepersonifieerde bovennatuurlijke krachten geleidelijk vervangen door abstracte filosofische begrippen. Dit tijdperk van theoretische abstracties is in de ogen van Comte niet vruchtbaar voor de verdere ontwikkeling van de kunsten. Een terugval noemt hij dit echter niet, eerder zou dit als stagnatie moeten worden opgevat. Een verdere ontwikkeling zet pas weer door in het laatste, positieve stadium. In dit stadium krijgen de kunsten een vergelijkbare rol toebedeeld als in het theologisch tijdperk, namelijk een dienende functie in de verdere ontplooiing van Comtes religieus getinte utopie, zijn cultus van 'De Mensheid'. Positivistische kunst dient de verwerkelijking van de door Comte gepropageerde utopie dichterbij te brengen en daartoe moeten vormen en stijlen verder ontwikkeld worden, van imitatie naar idealisering en expressie. ${ }^{6}$

Hoewel de artificieel-godsdienstige toekomstidealen van Comte nooit zijn aangeslagen, is zijn opvatting over vooruitgang in de kunst van belang: zowel de idee dat de kunsten zich als deel van een maatschappelijk proces noodzakelijk ontwikkelen als de idee dat kunst een propagandistische, geëngageerde functie heeft, zullen invloed hebben op het latere vooruitgangsdenken over kunst, vooral natuurlijk op marxistische theorievorming en op het denken van de avant-garde.

De overtuiging dat er vooruitgang in de kunsten valt aan te wijzen en dat die vooruitgang deel uitmaakt van een allesomvattend proces, manifesteerde zich eveneens in Engeland, zij het op een wat andere manier. In de eerste helft van de negentiende eeuw waren, althans in intellectuele kringen van Groot-Brittannië, vooruitgangsideeën gemeengoed geworden, hoewel aanvankelijk ook hier weer de achttiende-eeuwse scepsis ten aanzien van de kunsten bleef bestaan. De dichter en schrijver Thomas Love Peacock weet dit aan de irrationele eigenschappen die hij aan kunst toeschreef. Over poëzie verkondigde hij in The Four Ages of Poetry (1820) dat zij welbeschouwd een atavistisch, ja zelfs kinderachtig verschijnsel was: 
Poetry [originally] was the mental rattle that awakened the attention of intellect in the infancy of civil society: but for the maturity of mind to make a serious business of the playthings of its childhood, is as absurd as for a full-grown man [...] to be charmed to sleep by the jingle of silver bells.7

Dit is een ambivalent geluid, dat gedurende de negentiende eeuw als een basso continuo onder het lawaai van alle vooruitgangsmuziek door slingert. Waar aan de ene kant de kunsten hun waarde ontlenen aan het irrationele, het onbevangene en aan de fantasie, die in de romantiek zo hoog werden gewaardeerd, neemt tegelijkertijd de van de verlichting geërfde scepsis jegens zulke verschijnselen toe. Veelzeggend is in dit opzicht de opvatting van Macaulay, die niet elke vooruitgang in de kunst ontkende, maar die meende dat vooruitgang in de poëzie omgekeerd evenredig was aan vooruitgang van de cultuur in het algemeen. Naarmate immers de kennis toeneemt, moet poëzie het eerder afleggen en raakt ze in verval, zo schreef hij in $\mathrm{i} 825 .{ }^{8}$

Herbert Spencer integreerde de vooruitgang van de kunsten echter moeiteloos in zijn beschrijving van een alomvattend vooruitgangsproces, door ze in termen van een evolutiemodel te beschrijven. Hoewel hij een tijdgenoot van Darwin was, is er van diens invloed nauwelijks sprake: Spencer ging eerder terug op Lamarck, Malthus en K.E. von Baer. Hij beperkte zich in zijn model ook niet louter tot evolutie in de biologische betekenis, maar verbond zijn gedachten over ontwikkeling met sociale theorieën tot een geïntegreerde 'synthetische filosofie', een universeel systeem waarin biologische, psychologische, sociologische en ethische observaties in het licht van de evolutie worden beschreven. Evolutie is volgens Spencer integratie van stof en daaraan gekoppelde spreiding van beweging, waarbij de stof overgaat van een onbepaalde onsamenhangende homogeniteit naar een bepaalde, samenhangende heterogeniteit. Evolutie is een kosmisch, gradueel en cumulatief proces, dat normatief gezien wenselijk is en dus vooruitgang mag heten. Deze wel zeer abstracte ideeën zijn goed te illustreren aan de hand van Spencers opvattingen over evolutie in de kunsten.? 
Spencer beschrijft hoe de verschillende kunsten zich in een evolutionair proces geleidelijk ontwikkelen vanuit enkele ongedifferentieerde primitieve manifestaties van cultuur tot steeds complexere verschijnselen. Zo ontstaan in de loop van de geschiedenis muziek en poëzie uit dans en spruiten schilderkunst en beeldhouwkunst uit 'architectuur' voort, omdat versieringen zich langzamerhand losmaken tot zelfstandige vormen. In een later stadium uit zich een verdere differentiatie tussen beeldhouw- en schilderkunst in het afzien van kleurgebruik door de eerste. Spencer beschrijft ook een toenemende heterogeniteit in de overgang van religieuze naar seculiere kunst, in het ontstaan van steeds meer genres in de beeldende kunsten, en in de steeds complexere structuur van de kunstwerken zelf.

Een Egyptische wandschildering kent bijvoorbeeld geen diepte: de figuren staan in een plat vlak afgebeeld, zonder lichtschakeringen en met een beperkt aantal kleuren. Kleding, houding en gezichtsuitdrukking zijn stereotiep. Vergeleken met de latere westerse schilderkunst is deze kunst nog in grote mate homogeen, maar tevens onsamenhangend: zo'n Egyptische schildering bestaat uit een aantal losse plaatjes zonder onderlinge samenhang, als bij middeleeuwse wandtapijten. In moderne schilderijen is de variëteit in kleur, houding, expressie en lichtval zeer groot en daarom moet ook de voor de harmonie vereiste organisatie van ongelijksoortige elementen heel groot zijn; de heterogeniteit is met andere woorden coherent. ${ }^{\circ}$

De kunsten ontwikkelen zich volgens Spencer niet alleen in de richting van een samenhangende heterogeniteit, maar worden ook steeds duidelijker afgebakend (more definite); de weergave in de beeldende kunsten zou allengs realistischer geworden zijn (wat echter in Spencers tijd al niet meer onomstreden is), individuele karakters uit de literatuur zouden steeds 'natuurlijker' en psychologisch verfijnder zijn beschreven, enzovoort. 
De negentiende-eeuwse cultuurwetenschap: van rotswand tot Rembrandt

In de loop van de negentiende eeuw valt in verschillende Europese landen een sterke opkomst te bespeuren van wat -sinds het onderscheid van de neo-kantiaan Rickert in zijn Kulturwissenschaft und Naturwissenschaft (1899) - 'cultuurwetenschappen' is gaan heten. Deze wetenschappelijke belangstelling voor cultuur was voor het grootste deel historisch getint; of het nu taalkunde, antropologie of de bestudering van de kunsten betrof, steeds werden vragen gesteld naar het begin, het ontstaan, het verloop en de ontwikkeling van cultuurverschijnselen. Kunstwetenschappers gingen bij al dat historisch onderzoek impliciet uit van een van de drie geschiedperspectieven die hierboven werden genoemd, en soms van meer tegelijk.

De historische standaardoverzichten van met name muziek en beeldende kunsten beginnen steevast, veelal tot op de dag van vandaag, bij primitieve, half-geciviliseerde stammen, die ooit bemerkten dat de snaar van hun boog niet alleen pijlen afschoot maar ook klanken voortbracht en die de goden gunstig stemden voor de jacht door rotswanden te beschilderen. Vervolgens worden dan de Mesopotamische, Egyptische, Griekse, Romeinse en vroeg-christelijke beschavingen behandeld en daarna een reeks stijlperiodes vanaf de middeleeuwen via renaissance en (later) barok tot classicisme en romantiek. (Literatuurgeschiedenissen begonnen en beginnen doorgaans met de aanvang van een eigen, nationale literatuur in de middeleeuwen.)

Aan zulke historische overzichten liggen vaak evolutie- en vooruitgangsideeën ten grondslag, die de opeenvolgende beschavingen en periodes in een zinvol dan wel dwingend lineair verband groeperen, dat een toenemende beschaving impliceert. Ze weerspiegelen het uitgangspunt van E.B. Tylors Primitive Culture uit I87I,

that the savage state in some measure represents an early condition of mankind, out of which the higher culture has gradually developed or evolved, by processes still in regular 
operation as of old, the result showing that, on the whole, progress has far prevailed over relapse. "I

Een dergelijke modellering van het verleden in termen van vooruitgang en ontwikkeling nam op verschillende gebieden een hoge vlucht. In Frankrijk probeerde Ferdinand Brunetière de literatuurgeschiedenis te modelleren naar het evolutiemodel van Darwin, onder andere om de ontwikkeling van genres te kunnen verklaren. Evenzo beschreven Engelse literatuurhistorici als John Addington Symonds en Richard Green Moulton de geschiedenis van het Elizabethaans theater vanuit een op Darwin geïnspireerd evolutionisme en modelleerde H.M. Posnett zijn benadering van literatuurgeschiedenis naar de evolutieprincipes van Spencer. ${ }^{2}$ Positivistische vooruitgangsnoties vormden het kader van de taal-en letterkundige W. Scherer ( $\mathrm{Ge}$ schichte der deutschen Literatur, 1883 ), hoewel hij ook een cyclisch patroon van 600 jaar in de geschiedenis van de literatuur meende te kunnen bespeuren. Scherers kijk op de ontwikkeling van taal en literatuur had een sterk deterministische inslag, door hemzelf gekarakteriseerd door de drievoudige formule: 'Ererbtes, Erlerntes, Erlebtes.' Hij doelde daarmee op de determinerende ontwikkelingsfactoren van nationaal erfgoed en familieafkomst, op de letterkundige traditie en op biografische omstandigheden.

Scherers combinatie van vooruitgangsperspectieven en determinisme vertoont overeenkomst met het werk van Hippolyte Taine, die - onder sterke invloed van Hegel, maar zonder diens vergaande finalisme - de geschiedenis van de kunsten opvatte als deel van een samenhangende, algehele ontwikkeling van de cultuur, in het verlengde van een comtiaans positivisme. Volgens Taine wordt de totstandkoming van een kunstwerk bepaald door 'race, milieu, moment', dat wil zeggen door de eigenaardigheden van een volk, door de traditie en de maatschappelijke omstandigheden en door het tijdstip van een karakteristieke periode uit het historische proces, waarop het kunstwerk ontstaan is. Deze gedetermineerde vooruitgang werd bij Taine echter danig gerelativeerd door zijn sombere 
mensbeeld, dat wel wetenschappelijke vorderingen erkende maar toch van hardnekkige scepsis ten aanzien van moraal en kunst bleef getuigen. ${ }^{13}$

Ook de muziekgeschiedenis vertoont, deels tot op heden, een vergelijkbare aanblik. In het verlengde van het werk van Duitse muziekhistorici als H. Riemann en, iets later, G. Adler, verschijnt geleidelijk een stroom van historische overzichten in evolutionair perspectief, of geschreven vanuit vooruitgangsnoties, die hooguit worden gerelativeerd ten aanzien van contemporain werk dat aarzelend tegemoet wordt getreden. Pas in de tweede helft van de negentiende eeuw ontstaat de kunstgeschiedenis als een wetenschappelijke discipline, wanneer kunstfilosofische opvattingen, traditionele kunstkritiek, toenemend empirisch onderzoek en vooruitgangspositivisme samengaan. Belangrijk is het overzichtswerk van Carl Schnaase en ook dat van Franz Kugler. Kuglers invloedrijke Handbuch der Kunstgeschichte $(1842)$ probeert niet veel minder dan alle kunstwerken van alle volkeren van de hele geschiedenis in kaart te brengen. ${ }^{14}$

Rond 1900 ontstaat in de geschiedschrijving van de verschillende kunsten een aantal methodologische discussies en controverses. Ondanks hun grote verscheidenheid zijn vele ervan te herleiden tot het problematiseren van periodisering en van evolutie-ideeën die de blik op het verleden allengs waren gaan structureren. Maar ook in ruimere zin kwam er steeds meer verzet tegen allerlei vormen van historisch periodedenken. Enerzijds was dat in de traditie van het historisme al langer het geval (met als illuster voorbeeld het werk van Jacob Burckhardt), anderzijds kwam er steeds meer weerstand tegen 'de uitwassen van de historische geest, waaronder het heden gebukt gaat', zoals Nietzsche dat reeds in 1874 in zijn tweede Unzeitgemäße Betrachtung noemde. Het wordt nu de hoogste tijd, schreef Nietzsche,

gegen die Ausschweifungen des bistorischen Sinnes, gegen die übermäßige Lust am Prozeße auf Unkosten des Seins und Lebens, gegen das besinnungslose Verschieben aller 
Perspektiven mit dem ganzen Heerbanne satirischer Bosheiten vorzurücken. "s

En al was het meestal niet met de door Nietzsche gewenste satirische kwaadaardigheid, het oproer tegen het negentiendeeeuwse historische denken over cultuur brak onmiskenbaar uit, in de hermeneutische benadering van Dilthey bijvoorbeeld of wat later in de filosofie van Bergson en de invloedrijke esthetica van Croce. Sinds het begin van deze eeuw zijn ideeën over evolutie en vooruitgang in de kunst in althans de cultuurwetenschappen sterk op de achtergrond geraakt, parallel overigens met een meeromvattende relativering van vooruitgangsideeën in het begin van deze eeuw. ${ }^{16}$

Het nadenken over een theoretische ordening van de geschiedenis van de kunsten voerde vaak tot historistische interpretaties waarin periodiseringsproblemen het veld ruimden voor tamelijk speculatieve (maar lang niet altijd onvruchtbare) theorieën over stijlanalyse, zoals bij Wölfflin (Geschichtliche Grundbegriffe, 1915) of over (an het begrip Zeitgeist verwante) opvattingen als van Alois Riegl. De laatste probeerde kunstwerken uit het verleden vooral vanuit hun eigen tijd te begrijpen, als uitdrukking van een op dat moment heersend 'Kunstwollen'. Zo liet hij in zijn Spätrömische Kunstindustrie (1901) zien dat de periode van oud-christelijke kunst niet als een vervalstadium behoefde te worden gezien, wanneer men maar oog had voor de andere normen waarvan deze kunst een uitdrukking was.

De manier waarop het denken over vooruitgang in de kunst in de cultuurwetenschappen gestalte kreeg, is bij dit alles slechts een deel van het verhaal. Minstens even belangrijk is de vraag hoe kunstenaars en hun publiek zich tot een historische situering van de kunsten verhielden. Met de verzelfstandiging van het esthetisch domein sinds de romantiek waren het immers in eerste instantie de kunstenaars zelf, en daarna de critici en het publiek, die vaststelden wat kunst en wat haar relevante geschiedenis was en in hoeverre er in die geschiedenis van vooruitgang of ontwikkeling gesproken kon worden. Door de ontstane 
autonomie van het domein van de kunst werden de verschillende cultuurwetenschappen wellicht eerder een reflectie op en een doordenking van dat domein, dan dat ze in de eerste plaats constituerende uitspraken deden over de mate van vooruitgang in de kunst.

Commentaar en reflectie zijn bovendien een grotere plaats in de kunsten zelf gaan innemen. Aan het eind van de negentiende eeuw beginnen zich steeds meer kunstbewegingen te manifesteren, die idealen propageren in een discours van vooruitgangsideeën, een discours dat doortrokken is van een weer actueel geworden revolutiebegrip. Sinds de eeuwwisseling neemt het gehalte aan commentaar en reflectie op de identiteit van kunst in de kunstwerken zelf snel toe. Dada wordt hiervan de eerste grote uitbarsting. Vanaf dat ogenblik is het conceptuele bestanddeel in de verschillende takken van twintigste-eeuwse kunst niet meer weg te denken: sindsdien ontleent veel kunst haar betekenis en waarde aan een complex discours van commentaar en - vaak uiterst eclectische en associatieve - theorievorming. Hoeveel nuanceringen hierin ook kunnen worden aangebracht, duidelijk is dat de uitlatingen van kunstenaars en kunstkritiek hiermee de nodige aandacht beginnen te verdienen. Daartoe valt nu het licht op modernisme en avant-garde.

\section{Modernisme en avant-garde}

Over de betekenis en het ontstaan van het begrip 'modern' (modernisme, moderniteit, enzovoort) is de laatste decennia veel geschreven, vooral natuurlijk sinds de opkomst van het postmodernisme. Het is opvallend, zoals reeds geconstateerd werd, dat deze historische begrippen aanvankelijk vooral in een esthetische context figureerden. Dit suggereert op zijn minst enige relevantie van vooruitgangs- en veranderingsbegrippen in de kunsten ten opzichte van een ruimere betekenis van modernisering. ${ }^{17}$

De recente geschiedenis van de betekenis van het begrip 'modern' is tamelijk complex, maar wordt iets transparanter als een 
onderscheid wordt gemaakt tussen 'modern' als tegengesteld aan 'oud' of 'voormalig' en anderzijds als tegengesteld aan wat blijft of 'eeuwig' is. ${ }^{18}$ Deze tweede betekenis, verwant aan ons woord 'mode', wordt in de loop van de negentiende eeuw steeds prominenter en getuigt van een toegenomen historische tijdsbeleving zoals die in het eerste hoofdstuk aan de hand van Koselleck werd beschreven. Dit nieuwe tijdsbewustzijn maakt het mogelijk de term niet op één periode te laten slaan, bijvoorbeeld de romantiek, maar met de veranderende tijd een andere inhoud te laten krijgen.

In 1859 verscheen van Baudelaire Le peintre de la vie moderne, een studie over de schilder Constantin Guys. Hierin stelt hij dat het Schone zich in het steeds veranderende ideaal van de eigen tijd kan manifesteren terwijl anderzijds in het vluchtige en contingente (te vergelijken met Perraults beau relatif) toch het 'eeuwig Schone' te voorschijn komt. Volgens Baudelaire is schoonheid van nature ambivalent omdat juist het Schone het tijdelijke en het eeuwige in zich verenigt:

La modernité, c'est le transitoire, le fugitif, le contingent, la moitié de l'art, dont l'autre moitié est l'éternel et l'immuable. ${ }^{19}$

Sinds de tijd waarin Baudelaire het vergankelijke en contingente van het moderne heeft onderstreept, neemt het begrip langzamerhand steeds meer historische bewegingscategorieën in zich op. Zo houdt de opkomst van 'het moderne' gelijke tred met een toenemend gebruik van '-ismen', de karakteriseringen van 'stromingen' als socialisme, liberalisme, modernisme en -in de kunst -impressionisme, fauvisme, kubisme, surrealisme, enzovoort.

Baudelaire is ook in een ander opzicht een sleutelfiguur, waar hij in de traditie van de romantiek opnieuw op het belang van de verbeeldingskracht hamert. De imagination van de scheppende kunstenaar, die rusteloze activiteit van het genie, doorbreekt het banale kopiëren van de werkelijkheid volgens vaststaande regels. Deze in de achttiende eeuw opgekomen waardering voor 
de verbeeldingskracht confronteert het tijdelijke met het eeuwige en wordt daarmee de motor van het moderne. ${ }^{20}$

Het woord 'modern' kreeg in het laatste kwart van de negentiende eeuw allengs meer een normatieve lading, en daarmee een toenemende pragmatische strekking, interfererend met allerlei vigerende vooruitgangsnoties. Het wordt veelvuldig door maatschappelijke en artistieke groeperingen gebruikt. 'Il faut être absolument moderne,' zo verlangde Rimbaud. ${ }^{21}$ Het woord duikt telkens op in tijdschrifttitels en in beschouwingen over eigentijdse ontwikkelingen in maatschappij en kunst. In de Brockhaus-encyclopedie van 1902 wordt 'Moderne' als substantief dan ook als de 'Bezeichnung für den Inbegriff der jüngsten sozialen, literarischen und künstlerischen Richtungen' omschreven. ${ }^{22}$ (Het woord Richtung is in dit opzicht natuurlijk veelzeggend, evenals de steeds gangbaarder wordende termen 'stroming' en 'beweging'.)

Rond 1900 valt in esthetische discussies echter in toenemende mate het begrip 'avant-garde' te bespeuren, dat in een aantal opzichten dicht bij 'modernisme' ligt en door velen ook daarmee wordt vereenzelvigd, met name in de Angelsaksische traditie. De term zelf stamt uit het Franse militaire vocabulaire van het eind van de achttiende eeuw en wordt al tijdens de Franse Revolutie metaforisch gebruikt voor vooruitstrevende maatschappelijke tendensen. Saint-Simon paste het woord 'avant-garde' in I 825 voor het eerst op de kunst toe; hij wees kunstenaars een plaats aan in de voorhoede van het maatschappelijke proces van vooruitgang. Wat later omschrijft Sainte-Beuve het verzet van Stendhal tegen het classicisme in termen van een 'cheveau-léger [lichte ruiter] d'avant-garde', waarna het etiket 'les artistes de l'avant-garde' door de journalistiek geleidelijk ingeburgerd raakt, eerst voor literatuur en dan ook voor de andere kunsten. ${ }^{23}$ In het begin van de twintigste eeuw heeft het avantgardebegrip evenals 'modernisme' daarnaast nog wel een algemener maatschappelijke strekking, getuige bijvoorbeeld Lenins beroemde uitspraak uit 1902, waarin hij de communistische partij de 'avant-garde van de werkende klasse' noemt, maar in de loop der tijd handhaaft het begrip in de meeste landen hoofd- 
zakelijk een esthetische betekenis.

Toch schuilt er iets paradoxaals in het beklemtonen van het esthetische gehalte van het avant-gardebegrip, aangezien de avant-garde zich nu juist bij uitstek kenmerkte door haar verzet tegen de institutie kunst. De historische avant-garde verwierp kunst als een louter esthetisch verschijnsel dat binnen de maatschappelijke verhoudingen een autonoom domein had veroverd: kunst was in dit perspectief een soort reservaat geworden, dat niets meer met het leven zelf of met de samenleving had uit te staan. In deze zin had de kunst daarom afgedaan. Dat de avant-garde in de twintigste eeuw desondanks de belangrijkste institutionele kunststroming en meest toonaangevende ideologie binnen het gehandhaafde domein van de kunst is geworden, bewijst dus tegelijkertijd haar falen: het maatschappelijk succes van de avant-garde is haar grootste mislukking.

Deze paradox staat centraal in een terecht gezaghebbende verhandeling over de avant-garde van Peter Bürger: Theorie der Avantgarde (1974). In de avant-garde, aldus Bürger, wordt kunst zich van haar eigen categorieën bewust en ten gevolge daarvan kunnen zelfkritiek en reflexief commentaar van het 'maatschappelijk deelsysteem' kunst zich ontplooien. Die zelfkritiek is echter radicaler en verder strekkend dan systeemimmanente kritiek. Zo viel Dada het institunt kunst aan en niet één bepaalde stijl of stroming. Dada wilde helemaal geen kunst meer zijn; 'Kunst,' zo schreef Picabia strijdbaar in zijn Dadamanifest uit 1920, 'is een farmaceutisch produkt voor imbecielen." 24

Een minder extreme tendentie van de avant-garde poogde eerder de kunst weer in de 'Lebenspraxis' te incorporeren en wilde slechts het autonome karakter van de kunst, het estheticisme vernietigen en niet de kunst zelf. De kunstenaar zou zich niet langer achter l'art-pour-l'art-beginselen moeten verschansen en weer in de maatschappij en in het gewone leven moeten terugkeren. Aldus is de avantgardistische kritiek op het institunt kunst achteraf wel degelijk als deel van het esthetisch domein zelf te beschouwen: de avant-garde wordt dan geïnterpreteerd als een reactie op het estheticisme van onder andere 
symbolisme en decadentisme. Zij levert zodoende - als kunststroming - commentaar op een toonaangevende stroming die nu bij een achterhaalde traditie kan worden ingelijfd. Deze vorm van avant-gardekritiek richtte zijn pijlen op het ivorentorenkarakter dat de kunsten aan het eind van de negentiende eeuw hadden verworven en dat Edmund Wilson met betrekking tot literatuur zou aanvallen in Axel's Castle. Die kritiek slaagde er echter niet in, en beoogde dit ook meestal niet, om het instituut kunst als geheel omver te werpen, aldus de weg plaveiend voor de neoavant-garde en de genoemde paradox. ${ }^{25}$

De avant-garde verzet zich tegen de bereikte status van de kunst als een van de 'levenspraxis' gescheiden institutie; zij wil de kunst, in de dialectische interpretatie van Bürger, opheffen in hegeliaanse zin. Zij vergeet daarbij dat dit geen interne aangelegenheid is, maar deel uitmaakt van een veel meer omvattend historisch-maatschappelijk proces. De door de avant-garde beoogde 'Aufhebung' is 'falsch', want haar ideaal kan niet in de 'burgerlijke maatschappij' worden gerealiseerd ondanks haar 'Pathos historischer Fortschrittlichkeit', aldus Bürger. ${ }^{26}$

Zo gauw de radicale variant van de theoretische avant-garde in ogenschouw wordt genomen, blijken zich nauwelijks meer mogelijkheden voor te doen om vooruitgang in de kunst te ontwaren, omdat de ontwikkeling van kunst in deze variant, net als bij Hegel, tot haar opheffing leidt. In de extreme taal van de dadaïstische pamfletten (die we met enige armslag moeten interpreteren aangezien deze pamfletten niet als essayistisch proza bedoeld zijn en ze de wetenschap, de logica en het verstand voortdurend op de hak nemen), wordt bij herhaling afstand genomen van verleden en toekomst. Tristan Tzara schreef in zijn Dadamanifest uit 1918:

$D A D A ;$ afschaffing van het geheugen: DADA; afschaffing van de archeologie: DADA; afschaffing der profeten: DADA; afschaffing van de toekomst.

Ook over het begrip 'vooruitgang' liet hij zich niet onbetuigd: 
Als ik roep:

IDEAAL, IDEAAL, IDEAAL

KENNIS, KENNIS, KENNIS

BOEMBOEM, BOEMBOEM, BOEMBOEM,

is dit een vrij nauwkeurige weergave van de vooruitgang, de wet, de moral en alle andere schone hoedanigheden die allerlei zeer intelligente lieden in zoveel boeken bebben besproken. 27

\section{De radicale avant-garde ontkent en bespot vooruitgangsideeën} in de kunst omdat de kunst zelf overwonnen dient te worden. Het is een mooi spiegelbeeld van wat in het vorige hoofdstuk zichtbaar werd, waar de kunsten juist aan de discussie over vooruitgang in de cultuur hun identiteit begonnen te ontlenen.

De radicale avant-garde maakt vooruitgangsideeën bovendien belachelijk omdat zij haar eigen opstelling niet als een consequentie van ontwikkelingen in het verleden wil opvatten, maar als een breuk met het verleden - en dus als een ontkenning ervan. In deze polemische variant van de avant-garde wordt telkens naar het verschil gezocht; de kunstenaar brengt, om het in de woorden van Octavio Paz te zeggen, een verbinding aan tussen de esthetica van de verrassing en die van de ontkenning. ${ }^{28}$ Daarmee krijgt het revolutionaire pathos van de romantiek, waarin een radicale breuk met de traditie verordonneerd wordt, een nieuwe en voor de ontwikkeling van de kunst in de twintigste eeuw verstrekkende impuls.

De minder extreme hoofdmoot van avant-gardebewegingen interpreteert met allerlei nuanceringen en varianten de gebeurtenissen en kunstwerken wel in een of ander vooruitgangsperspectief. $\mathrm{Zij}$ poneert doorgaans ook een breuk met het verleden, maar die is niet absoluut, want met de beoogde eliminatie van de autonome status van de kunst maken artistieke ontwikkelingen weer deel uit van een maatschappelijk proces, en dit proces wordt door de avant-garde veelvuldig in termen van vooruitgang - of minstens als een, soms vaag, utopisch verlangen geïnterpreteerd. Hoezeer de Italiaanse futuristen zich bijvoorbeeld ook tegen het verleden (en het heden en van alles en nog 
wat) afzetten, hun beweging is onomstotelijk van utopistische aard. Zij bestoken de geschiedenis met de door Nietzsche zo verlangde satirische Bosheiten, zoals hun pleidooi voor verwoesting van alle musea, maar hun bewondering voor de techniek en 'de machine' en hun poging tot een radicale esthetisering van de maatschappij te komen, kortom hun 'modernolatrie', getuigt van een geschiedenis-, of beter misschien, tijdsopvatting die niet van vooruitgangsnoties vrij is. Bij het Russische futurisme is dit nog duidelijker door de verwevenheid van deze beweging met maatschappelijk-revolutionaire stromingen, door de allesbeheersende gerichtheid op zowel een nieuwe kunst als op een nieuwe maatschappij. Ook de surrealisten en in mindere mate de constructivistische ideologie, voor zover die de geïsoleerde autonome positie van de kunst verwerpen, staan een maatschappelijk engagement voor, waarin kunst soms ook een propagandistische waarde heeft, maar bovenal als een integraal bestanddeel van de nagestreefde utopie wordt beschouwd.

Hoezeer de vernieuwingen in de kunst van de avant-garde ook telkens in termen van vooruitgang werden gepresenteerd en verdedigd, zoals in de volgende hoofdstukken nog zal blijken, het bleef voor de pleitbezorgers van de avant-gardekunst toch buitengewoon lastig deze vooruitgang te beargumenteren. Allereerst is kunst in de ogen van de avant-garde geen autonome institutie meer, zodat zij haar identiteit verliest: ontwikkelingen kunnen in dat geval alleen in een algemener perspectief worden beoordeeld en niet meer als vooruitgang van of in de kunst. Dit bezwaar is echter, gezien de paradoxale ontwikkeling van de avant-garde tot een uiterst succesvolle, autonome kunststroming, niet zwaarwegend, of althans niet fataal. Ingewikkelder ligt het met de idee dat er een breuk met het verleden is. Zoals Bürger schrijft:

Men moet heel ernstig overwegen, of het breken met de traditie, zoals de bewegingen der historische avant-garde dat hebben bewerkstelligd, het spreken over een historische stand van zaken in artistieke technieken met betrekking tot het heden niet zinloos [gegenstandslos] heeft gemaakt. ${ }^{29}$ 
Volgens Bürger beschikken de kunsten sinds de avant-garde over allerlei procédés en stijlvormen uit voorbije tijdperken. Als voorbeeld geeft hij de techniek van oude meesters bij sommige schilderijen van Magritte, maar men kan ook denken aan de romantische belangstelling voor de droom bij de surrealisten of voor het primitivisme bij een cubist als Picasso, als men deze tenminste tot de avant-garde wil rekenen. Door de ideologie van de breuk, het verlangen naar het nieuwe en naar provocatie en door de experimentele pogingen tot voortdurende grensoverschrijding is de historische volgorde van procédés en stijlen getransformeerd in een 'Gleichzeitigkeit des radikal Verschiedenen'. En dat heeft tot gevolg, aldus Bürger

\section{dat geen artistieke beweging er tegenwoordig nog legitiem aanspraak op kan maken als kunst in historisch opzicht meer te zijn vooruitgegaan [historisch fortgeschrittener zu sein] dan andere bewegingen. 30}

De problematische verhouding tussen het 'breukdenken' en de gelijktijdigheid van een grote verscheidenheid enerzijds en ideeën over vooruitgang in de kunst anderzijds is a fortiori van toepassing op de ontwikkeling van de verschillende kunsten sinds de historische avant-garde, van de naoorlogse neoavantgarde tot op de postmoderne dag van vandaag.

Daar komt de reeds genoemde complicatie bij, dat de verschillende kunsten sinds modernisme en avant-garde in snel toenemende mate een discours van kunstkritiek in het kunstwerk zelf hebben opgenomen. Steeds meer kunst, of het nu muziek is, of literatuur, film of beeldende kunst, bestaat bij de gratie van commentaar dat het werk op andere werken, kunstenaars, tradities en sociale omstandigheden van de kunst zelf bevat. Hoewel van een impliciet geloof in vernieuwing en vooruitgang nauwelijks afscheid lijkt te zijn genomen, wordt in deze ontwikkeling voortdurend een dubbelzinnige, maar daarom nog niet minder radicale kritiek op de traditie geleverd, die de mogelijkheid tot een geschiedopvatting waarin een patroon van vooruitgang valt te herkennen, welhaast tot nul reduceert. In 
zoverre de moderne kunst te identificeren is met dit steeds belangrijker geworden conceptuele bestanddeel, worden vooruitgangsideeën grotendeels obsoleet. In die zin is Duchamps beroemde fietswiel op het krukje niet alleen het begin van 'de moderne' beeldende kunst, maar ook een eindpunt. Kunst is opgelost in een discours dat een beschouwing in termen van vooruitgang absurd lijkt te maken. Daarmee belanden we bij de in de inleiding aangesneden discussie met Danto, die om dergelijke redenen het einde van de beeldende kunst verkondigt.

Hoezeer vooruitgangsideeën ook steeds in de praktijk van de kunsten en in het discours waarin ze functioneren zijn voorondersteld, telkens lijken ze weer tot een aporie te voeren. Het finalisme en het revolutiedenken van de romantiek bleven het uitgangspunt van een lineaire tijd, en dus van continuitteit, aantasten. De positivistische traditie van de negentiende eeuw verkleinde de eigen identiteit van de kunsten door ze als deel van een allesomvattend proces te begrijpen en ze aldus tot franje van maatschappelijke ontwikkelingen te reduceren. Dat is ook het geval bij een evolutionaire benadering als die van Spencer en bij de manier waarop de historische cultuurwetenschappen de kunsten in het korset van een al te eenvoudig model probeerden te rijgen. Een van de grootste problemen bleek bovendien de toenemende reflectie die binnen de kunstwerken zelf begon op te treden.

Toch is het nog te vroeg om de vraag te beantwoorden of het in alle opzichten zinloos is om van vooruitgang in de kunsten te spreken. Die vraag wordt tot de slothoofdstukken bewaard. $\mathrm{Na}$ het historisch overzicht van de afgelopen twee hoofdstukken dient zich nu eerst een meer systematische vraag aan, de vraag hoe vooruitgangsbegrippen in de kunst of met betrekking tot kunst gebruikt worden, waarom ze zo verleidelijk zijn. Daarom lijkt het verstandig de context waarin ze figureren eens wat nauwkeuriger te bezien. 


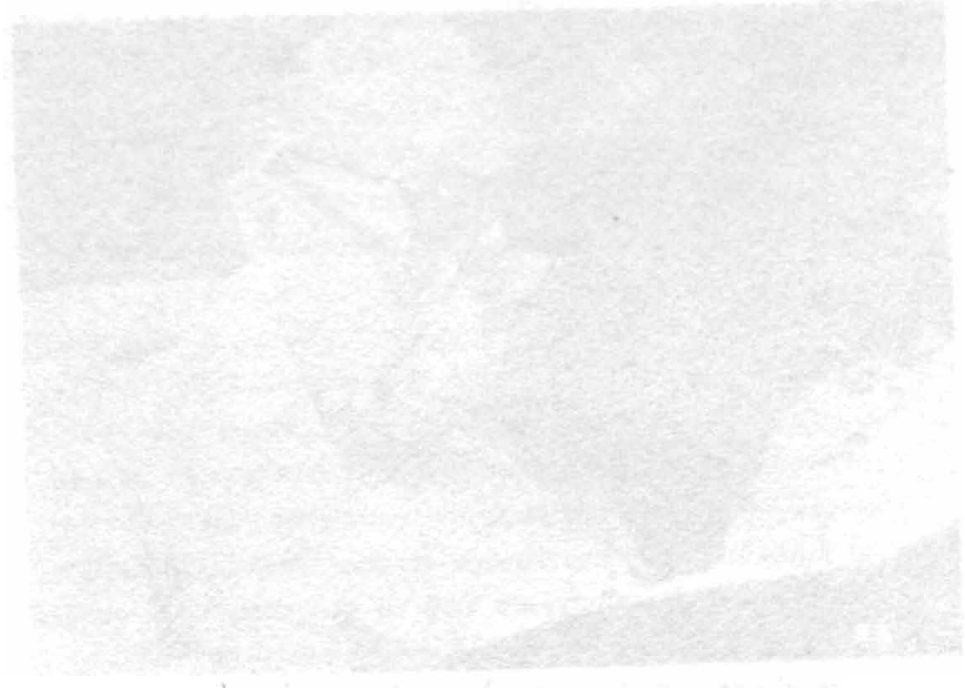




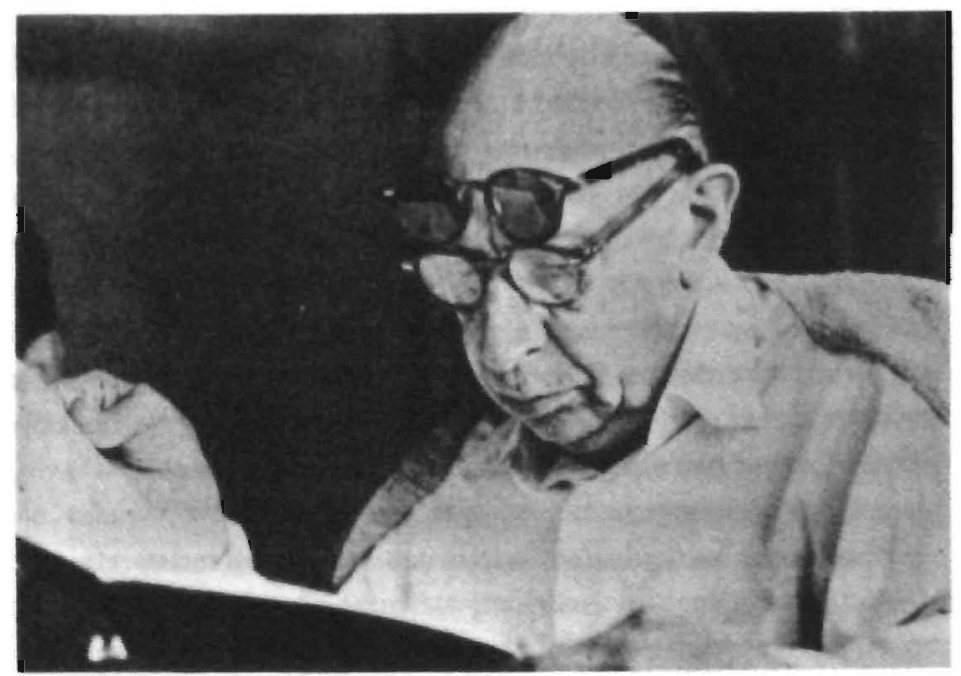

Igor Stravinsky op latere leeftijd 


\section{Over het maken van revolutie}

\section{De kleine Modernsky}

Op 28 mei 1913 ging in het nieuwe Théatre des Champs Elysées te Parijs Stravinsky's Sacre du Printemps in première, gedanst door de befaamde Ballets Russes onder leiding van Djagilev en met Nizjinski als voornaamste danser. Later herinnerde Stravinsky zich van de eerste opvoering van dit spraakmakende muziekstuk nog het volgende:

Nawwelijks was het stuk begonnen of er brak een hoongelach uit, en ik kan niet over de nitvoering oordelen omdat ik vanaf de eerste maten van bet Preludium de zaal reeds verliet. Ik was razend. Deze uitingen die aanvankelijk slechts bier en daar voorkwamen werden weldra algemeen. Tegenbetogingen ontstonden en er brak een verschrikkelijk lawaai los. Gedurende de bele voorstelling bleef ik verder acbter de coulissen bij Nizjinski. Deze schreeuwde boven op een stoel staande uit alle macht tegen de dansers: 'zestien, zeventien, achttien...', want ze hadden zo hun eigen manier om de maat bij te houden. Overigens hoorden de arme dansers er geen woord van vanwege bet tumult in de zaal en hun eigen stampvoeten. Ik moest Nizjinski bij zijn kleren vastgrijpen, want hij was buiten zichzelf en kon ieder ogenblik van het toneel springen om schandaal te maken. Djagilev van zijn kant beval de elektriciens, teneinde bet tumult te doen bedaren, het licht in de zaal aan en mit te doen gaan.' ${ }^{\prime}$

In de daaropvolgende maanden werden voorstanders en sceptische critici van dit zoveel ophef veroorzakende muziekstuk het 
al spoedig over één ding eens: de gewaagde dissonanten, de tot dan toe ongehoorde ritmewisselingen en de explosieve contrasten van de Sacre du Printemps hadden de geschiedenis van de muziek voorgoed veranderd. Stravinsky leek een van de belangrijkste vernieuwers van de twintigste-eeuwse muziek te gaan worden.

Vanaf de Eerste Wereldoorlog sloeg Stravinsky echter een richting in die als neo-classicisme bekend zou komen te staan en waarin hij allengs meer teruggreep op oude componisten, van J.S. Bach tot Rossini, en steeds meer putte uit de klassieke harmonie van de laatste twee eeuwen. De muzikale aanval op de traditionele tonaliteit zou voortaan door anderen worden voortgezet - in de eerste plaats door Schönberg.

Stravinsky tekende protest aan tegen het neo-classicistische etiket dat hij kreeg opgeplakt. Maar hoezeer hij in latere publikaties ook probeerde de consequente ontwikkeling in zijn werk te onderstrepen en te verhelderen, de toonaangevende kritiek bestempelde hem als een reactionair of deed hem op zijn minst af als 'ouderwetsch', zoals Willem Pijper hier te lande in een overzicht van de moderne muziekgeschiedenis schreef; Pijper vond dat bij Stravinsky kon worden volstaan met de constatering 'dat de composities welke na 1924 verschenen zijn, steeds minder met de ontwikkeling der Europeesche muziek na Wagner te maken bleken te hebben'. ${ }^{2}$

Het is een veel gehoord verwijt. Al in 1925 had Arnold Schönberg de naar zijn idee reactionaire, kunstmatig op het verleden teruggrijpende Stravinsky bespot met de tweede van zijn Drie satires, op. 28 , waarvan de tekst luidt:

$J a$, wer trommelt denn da?

Das ist ja der kleine Modernsky!

Hat sich ein Bubizopf schneiden lassen;

sieht ganz gut aus!

Wie echt falsches Haar!

Wie eine Perïcke!

Ganz (wie sich ihn der kleine Modernsky vorstellt), ganz der Papa Bach! 
Ook de muziek van deze satire bevat ironische verwijzingen naar 'traditioneel' materiaal (einde in een unisoon gezongen grondtoon c, allusies op klassiek contrapunt, enzovoort). 3 Dergelijke kritiek blijft een constante in Stravinsky's leven; nog decennia later wordt hij met beschuldigingen van restauratie en conservatisme geconfronteerd.

Zo zet Adorno in zijn Philosophie der neuen Musik (1948) uiteen wat de verdiensten van Schönberg en de zonden van Stravinsky zijn. Zijn boek bestaat uit twee delen: 'Schönberg und der Fortschritt' en 'Stravinsky und die Restauration'. Hoewel Adorno moeilijk een naïef negentiende-eeuws vooruitgangsgeloof kan worden aangewreven, is deze aanpak al veelzeggend, evenals het aan Hegel ontleende motto dat boven het opstel over Stravinsky staat en dat in vertaling luidt:

Het helpt verder niets, om zich opnieuw wereldbeschouwingen uit het verleden als het ware substantieel toe te eigenen, d.w.z. zich aan een van deze levensoveriuigingen te willen bechten door bijv. katholiek te worden, wat velen recent omwille van de kunst gedaan hebben om hun gemoed tot rust te brengen. 4

Adorno's kritiek richt zich niet alleen op de mythologische inhoud van de Sacre du Printemps, zoals E.M. Mulder in haar opstel 'Perspectief en de dimensies der verbeelding' beklemtoont, maar ook op het feit dat Stravinsky niet de weg van de twaalftoonmuziek heeft ingeslagen, die ondanks Adorno's complexe dialectische betoogtrant toch als de ondubbelzinnige weg der vooruitgang blijkt te moeten worden opgevat. Nooit, zo klaagt Adorno, wordt de Sacre atonaal en ontworstelt hij zich aan het keurslijf van de tonaliteit, 'die Strawinskysche Regression [...] ersetzt [...] den Fortgang durch die Wiederholung'. Het is hetzelfde soort kritiek als waarmee de Amerikaanse naoorlogse kunstcriticus Clement Greenberg Picasso bestookte, die niet de onvermijdelijke conclusie uit de ontwikkeling van zijn eigen werk zou hebben willen trekken, namelijk de conclusie van totale abstractie, waarvan Greenbergs helden getuigden.s 


\section{Het heden als verleden van de toekomst}

Schandaalverwekkende vernieuwingen in de kunst als de Sacre $d u$ Printemps zijn in de afgelopen eeuwen moeiteloos te vinden en het schermen met vooruitgangsbegrippen om veranderingen bij te vallen dan wel af te keuren evenzeer. Waarom eigenlijk, wie doen dat en hoe?

De laatste decennia zijn deze begrippen weliswaar implicieter geworden en verdedigen nog maar weinig kunstbeschouwers openlijk dat er vooruitgang in de kunst bestaat, maar de soms krachtige ontkenning van die vooruitgang wekt vaak de indruk van een strijd met de in de inleiding genoemde hydra. Bovendien maken veel van dergelijke uitlatingen deel uit van een discours vol theorie en commentaar, van een hoeveelheid gecompliceerde ruis. En misschien wel meer dan ruis, want met de toenemende autonomie van het kunstwerk en met het daarmee gepaard gaande grotere conceptuele gehalte van kunst is reflectie op kunst steeds meer deel van de kunst zelf uit gaan maken. Kunstwerken leveren commentaar op andere kunstwerken, zoals Schönbergs satire al mocht illustreren; verder op zichzelf en de eigen totstandkoming (en soms zelfs opheffing); op de kritiek; op het publiek en op de waarneming of verwerking van wat ze zijn.

En wat de identiteit van kunstwerken is, wordt vooral bepaald door traditie, context en geschiedenis. Kunstwerk, kunstenaar en publiek zijn zich daarvan ook terdege bewust. Dit bewustzijn, of het nu gevoelsmatig is of juist expliciet wordt beredeneerd, maakt de ruis zo complex; in hoeverre is iets louter reflectie op een kunstwerk en in hoeverre maakt het deel uit van het werk zelf? Het fietswiel op de kruk van Duchamp is een goede illustratie van dit probleem, evenals Magrittes bij filosofen vaak precies om die reden zo geliefde afbeelding van een pijp, waaronder 'Ceci n'est pas une pipe' genoteerd staat. Commentaar en reflectie op kunstwerken zijn onlosmakelijk met kunst verbonden en dat geldt minstens evenzeer voor het historisch bewustzijn waarmee kunst wordt beleefd. Kunst is altijd in de tijd gesitueerd. 
Inmiddels is de vraag opgeworpen waarom er zo vaak in termen van vooruitgang over kunst is nagedacht en gesproken, wie dat doen, en op welke manier. Om te beginnen is het verstandig een ogenblik stil te staan bij wat er gebeurt wanneer iemand een recente artistieke prestatie in termen van vooruitgang interpreteert. Op het eerste gezicht tuurt zo iemand in een geordend verleden, ziet wat er tot stand is gebracht en plaatst vervolgens de nieuwe verworvenheid in het verlengde van een historisch verlopend proces.

Maar de strekking van vooruitgangsbegrippen omvat meer, zoals al in het eerste hoofdstuk bleek: ze zijn ook toekomstgericht. Wie gebeurtenissen of verworvenheden in deze termen beoordeelt, doet dan ook eigenlijk iets merkwaardigs. Hij neemt een omgekeerde verrekijker om wat vlakbij is van een afstand te bezien: hij beschrijft het heden als verleden van de toekomst. Wanneer Schönberg bijvoorbeeld zijn twaalftoonmuziek als vooruitgang in de muziek opvat, dan impliceert dit dat hij gelooft dat er vanaf dat moment zo zal moeten worden gecomponeerd en dat dat ook zal gebeuren. Er wordt, met andere woorden, geconstateerd dat een aantal jaren later zal worden vastgesteld dat hij een stap heeft gezet waarmee de muziek een bepaalde weg is ingeslagen. Het zijn dus niet alleen de historici die later vaststellen dat de geschiedenis een bepaalde loop heeft genomen; zo gauw er vooruitgangsbegrippen worden gebruikt, begint men geschiedenis te maken (of te consolideren) alsof men een toekomstig historicus is van de eigen tijd.

Vanuit het perspectief van de produktie van kunst is er een voor de hand liggende reden waarom er van vernieuwing en vooruitgang wordt gesproken. Hoe strak de regels ook zijn en hoe beperkt de bewegingsruimte voor een kunstenaar ook is, hij dient af te wisselen en niet eindeloos te herhalen: binnen de grenzen van het werk zelf en, even vanzelfsprekend, daarbuiten, in zijn oeuvre. (Zelfs repetitieve muziek en minimal art kennen variatie.) Afgezien van het probleem van reproduceerbaarheid (etsen, uitvoeringen van muziek en theater, enzovoort) is elk kunstwerk uniek, dat wil zeggen nooit een volstrekte kopie van een ander kunstwerk. Sinds de romantiek, maar ook al in de 
achttiende eeuw, wanneer het creatieve gehalte van kunst, zoals eerder is gebleken, belangrijk begint te worden, maken elk kunstwerk en elke kunstenaar bovendien aanspraak op originaliteit. In die zin zal kunst steeds veranderen en zal elke kunstenaar, gedwongen door de psychologie van het scheppen, waarin een besef van achteruitgang en teruglopende creatieve mogelijkheden fnuikend werkt (Stravinsky verzette zich niet voor niets tegen het verwijt van een terugval), de veranderingen in het eigen oeuvre als een voortdurende vooruitgang interpreteren. Zo'n individueel en psychologisch geduide vooruitgang is echter minder relevant wanneer het vooruitgangsbegrip als een algemener concept beschouwd wordt. Natuurlijk spelen de noties van individuele vooruitgang hierin wel een rol, maar belangrijker is het perspectief op een groep kunstenaars, op de stand van zaken in een discipline of op de algemene richting waarin de geschiedenis van een of andere kunsttak zich beweegt; dus eerder vooruitgang als een filosofische, cultuurhistorische en sociologische, dan als een psychologische of artistieke categorie. Niet de totstandkoming van een individueel kunstwerk of oeuvre is hier aan de orde, maar het bewustzijn met kunstwerken een onomkeerbare verandering tot stand te brengen in het verleden van de toekomst van een artistiek systeem.

Om dit perspectief reliëf te geven is het vruchtbaar onderscheid te maken tussen kleine veranderingen die plaatsvinden binnen een aantal min of meer vastliggende regels, en anderzijds veranderingen die die regels of normen overschrijden en daarmee een algemene vernieuwing tot stand brengen. Dit is tegenwoordig een gebruikelijk onderscheid in de geschiedschrijving van de verschillende kunsten. Van grote invloed op zo'n benadering is het ook voor andere kunsten dan de literatuur belangrijke Theory of Literature van René Wellek en Austin Warren. Zij stelden in dit boek voor de historische ontwikkeling van literatuur te bestuderen aan de hand van in het kunstwerk geldende normen en waarden. De geschiedenis van de literatuur werd door hen opgevat als een evolutie van zulke normen en waarden, waarbij het begrip 'periode' een van de belangrijkste 
instrumenten is. Een periode is dan een tijdspanne die beheerst wordt door een systeem van normen, standaarden en conventies en de introductie, verspreiding, variatie, integratie en teloorgang van deze waarden en gebruiken kan (en moet) worden opgespoord. Een periode wordt gekarakteriseerd als 'a time section defined by a system of norms embedded in the historical process'; de geschiedschrijving van periodes binnen een kunstvorm bestaat uit het opsporen van de veranderingen van het ene normsysteem naar het andere. ${ }^{6}$

Anbeek wijst er in de inleiding tot zijn Geschiedenis van de Nederlandse literatuur op, dat het door Wellek en Warren in I 947 geformuleerde gezichtspunt op literatuurgeschiedenis als een opeenvolging van systems of norms de laatste veertig jaar nauwelijks is aangetast. 'Alleen de terminologie is aan verandering onderhevig,' schrijft Anbeek:

Maar of men de literatuurgeschiedenis nu ziet als een opeenvolging van 'literatuuropvattingen' (Oversteegen) of 'periodecodes' (Fokkema), in beide gevallen gaat het om het beschrijven van veranderende literaire normen of conventies.?

Daarmee mag Anbeek aan allerlei historische nuances en theoretische scherpslijperij voorbijgaan, feit is dat literatuurgeschiedenis zich grosso modo blijft funderen op het tot het formalisme van Tynjanov en het Praagse structuralisme te herleiden schema, waarin ontwikkelingen aan de hand van samenhangende, interne normen en regels beschreven kunnen worden. Iets dergelijks geldt mutatis mutandis voor de geschiedschrijving van de andere kunsten, die niet meer alleen een galerij portretten in chronologische volgorde probeert te presenteren, maar die daarin ook inhoudelijke samenhang wil aanbrengen door periodes te construeren waarin bepaalde normen gelden, en demarcaties aan te brengen die aangeven hoe en wanneer die normen veranderen. 
Deze benadering vertoont een parallel met ontwikkelingen in de geschiedschrijving van de wetenschappen gedurende de laatste decennia. Het meest invloedrijk is hierin het werk van Thomas Kuhn geweest. ${ }^{8}$ Kuhn heeft veel oog voor de sociale en pragmatische aspecten van de ontwikkeling van wetenschap en voor de impliciete normen die het handelen van wetenschappers sturen en beperken. Zijn theorie verschilt echter in zoverre van bovengenoemde kunsthistorische opvattingen, dat volgens hem die normen zelden of nooit expliciet of bewust zijn; wetenschappers handelen op grond van examplars, voorbeelden die als standaard gelden voor wat deugdelijk werk is en wat niet, en die een onmisbaar bestanddeel van de opleiding van wetenschappers uitmaken.

Kuhn ziet in de geschiedenis van de wetenschappen steeds twee soorten periodes. Ten eerste die van de 'normale wetenschap', periodes waarin een aantal gebruiken vastligt, waarin overeenstemming bestaat over wat de toonaangevende theorieën zijn, wat de op te lossen problemen zijn, van welk (vaak metafysisch) standpunt wordt uitgegaan, kortom, waarin men het erover eens is hoe de wereld er (wetenschappelijk, epistemologisch) uitziet. Deze kijk op de werkelijkheid, het geheel aan veronderstellingen, spelregels en methoden van een bepaalde wetenschappelijke gemeenschap, heet bij Kuhn een paradigma.

Op een gegeven moment zijn alle puzzels binnen zo'n paradigma opgelost; of ze blijken onoplosbare kwesties dan wel verkeerd gestelde vragen; of er ontstaat door externe factoren een gevoel van crisis en onbehagen; uitgangspunten worden betwijfeld, een rivaliserend wereldbeeld dringt zich op. Dan vindt een wetenschappelijke revolutie plaats, zoals ooit tijdens de overgang van een aristotelische naar een moderne opvatting van het begrip 'beweging'. Zo'n revolutionaire fase vormt het tweede soort periode dat Kuhn onderscheidt.

Daarmee is overigens niet gezegd dat Kuhns model goede aanknopingspunten voor vooruitgangstheorieën biedt. Het 
aanstootgevende van zijn kijk op de geschiedenis was aanvankelijk juist dat hij zo'n vooruitgangsperspectief sterk relativeerde door de principiële onvergelijkbaarheid van verschillende paradigma's te articuleren, dus door te stellen dat opeenvolgende paradigma's niet vanuit een neutraal perspectief te vergelijken zijn, omdat ze elk iets anders willen verklaren en beschrijven. Volgens Kuhn weten we na zo'n wetenschappelijke revolutie niet méér van de wereld, maar ziet die wereld er eenvoudigweg anders uit. 9 Kuhns theorieën zijn hier van belang door de rijke historische interpretatie die ze hebben opgeleverd, een interpretatie waarin het verleden aanmerkelijk minder vervormd zichtbaar wordt. Zijn model maakt het mogelijk om veranderingen te bestuderen, zonder ze in termen van een rationele, op vooruitgang gestoelde reconstructie op te moeten vatten.

Het is de moeite waard een dergelijk model ook op de geschiedenis van de kunsten uit te proberen bij de vraag, waarom en op welke manier er in termen van vooruitgang in de kunst is gesproken en wie dat hebben gedaan. Deze toepassing van Kuhns model op de kunsten is niet nieuw. In 1985 publiceerde Remi Clignet (vanuit een wat andere vraagstelling) The Structure of Artistic Revolutions, waarin hij Kuhns onderscheid tussen normale wetenschap en revoluties op de kunsten toepast. Clignet beschrijft hoe artistieke paradigma's op een bepaald tijdstip uitgeput raken en hoe dan een artistieke revolutie plaatsvindt. Zo waren er in de geschiedenis van de schilderkunst bij het begin van het pointillisme nog genoeg mogelijkheden om de kleur, omvang en vorm van de op het doek aangebrachte punten te variëren en zo de verschillende lichteffecten te onderzoeken en weer te geven. Maar na enige tijd bood het programma van Seurat geen nieuwe oplossingen meer. Pas toen impressionisme en pointillisme 'had run their full courses' konden de fauvistische en kubistische revoluties zich voltrekken, aldus Clignet. ${ }^{\circ}$

Dit voorbeeld illustreert het arbitraire karakter van een louter interne benadering van veranderingen in de kunst naar analogie met wetenschap: want hoe weten we wanneer de hele weg van 
een stroming is afgelegd? Bij het pointillisme kan men zich hier nog wat bij voorstellen, zolang men niet te nauwkeurig wil worden, maar bij het impressionisme lijkt een inhoudelijke beschrijving van de grens, waarop de hele weg is afgelegd (of alle 'puzzels' zijn opgelost), al niet meer mogelijk. Clignet levert ons voor zijn bewering verder geen enkel circumstantial evidence, wat in concrete, en dus gecompliceerde gevallen overigens vaak ondoenlijk zal zijn. Het is dan ook relevanter om externe factoren (sociale structuren, maatschappelijke omstandigheden, technologische ontwikkeling e.d.) bij zo'n verandering te betrekken, iets dat bij Clignet door zijn conceptuele ruimdenkendheid slechts verspreid en weinig systematisch aan de orde komt. Daarom kunnen die beter aan de hand van Kuhns eigen opvattingen besproken worden, al zal hierbij een minder belangrijke rol aan examplars worden toegekend dan hij zelf doet. Kuhns model van wetenschap is niet de enige, noch de op voorhand meest geschikte manier om het functioneren van kunstpraktijken uitputtend te beschrijven, maar het model lijkt wel toegesneden op het analyseren van het praktische (retorische, strategische) gebruik van vooruitgangsbegrippen, zoals dat hier ter sprake komt.

Kuhn besteedt zelf trouwens enige aandacht aan de toepassing van zijn model op de kunst; in 'Comment on the relations of science and art' onderstreept hij echter vooral de verschillen en onmogelijkheden die zich bij zo'n vergelijking voordoen. Hij wijst er onder andere op dat de rol van het publiek - en daarmee de acceptatie van veranderingen - aanmerkelijk verschilt en verder, wat belangrijk is, dat in de kunst het verleden nooit zo definitief wordt afgezworen. Rembrandt blijft immers ook na Picasso's succes meetellen, terwijl Galilei definitief geschiedenis is geworden." I

Volgens Kuhn wordt een wetenschappelijke revolutie vaak aangekondigd door een anomalie die zich binnen een paradigma begint af te tekenen en die bovendien ook aandacht begint te krijgen (want op zich zijn anomalieën altijd wel aan te wijzen). Hij illustreert de verwarring die dan ontstaat met een psychologisch experiment van Bruner en Postman, die proef- 
personen herhaaldelijk vragen een reeks getoonde speelkaarten te beschrijven, waarbij deze proefpersonen geleidelijk een toenemend aantal afwijkende kaarten krijgen te zien, eerst bijvoorbeeld een rode schoppen-zes en een zwarte harten-vier en later steeds meer. Eerst beschrijven de proefpersonen deze kaarten zonder ophef te maken, maar na enige tijd blijken ze daar enorme moeite mee te hebben omdat er te veel van het gebruikelijke systeem wordt afgeweken. ${ }^{12}$

Een dergelijke verwarring kenmerkt zowel een wetenschappelijke revolutie, zoals Kuhn die beschrijft, als een artistieke revolutie. Men begint dan over uitgangspunten te twisten en er ontstaat rumoer, zoals dat zich in de geschiedenis van de muziek bij de Sacre du Printemps voordeed, of een gevoel van impasse, van waaruit een dichter als T.S. Eliot aan het begin van deze eeuw bewust een aantal vernieuwingen propageerde en in praktijk bracht. Aan zo'n situatie van verwarring ontlenen vernieuwingen het plotselinge karakter, dat gepaard gaat met de retoriek van geweld en vernietiging en met het revolutionaire vocabulaire dat in het begin van het vorige hoofdstuk geschetst werd.

Vaak speelt ook de uitvinding van nieuwe theorieën een rol in de onzekere stemming die aan een wetenschappelijke revolutie voorafgaat. ${ }^{3}$ In de kunsten moet hierbij echter eerder gedacht worden aan de uitvinding van nieuwe technieken of procédés. Bijvoorbeeld de toepassing van nieuwe materialen als ijzer en beton in de negentiende-eeuwse architectuur. De discussies die de sceptische, maar anderszins zeer vernieuwende vormgevers, denkers en architecten John Ruskin en William Morris hierover aangingen in hun verzet tegen de engineering architecture, deden een nu nog altijd gezaghebbend architectuurhistoricus in 1936 verzuchten dat

no new period in human civilization has ever arisen without an initial phase in which a complete upheaval of values took place; and such phases are not specially pleasant for contemporaries. ${ }^{14}$ 


\section{Steeds mooier}

De grote rol van nieuwe uitvindingen en procédés is evident. De mogelijkheden van de piano (vooral die van het hard en zacht spelen, en die van het aanhouden van een toon en het toegenomen geluidsvolume zelf) verdrongen vanaf 1750 het clavecimbel volledig. Het gaat misschien te ver om te beweren dat de piano de barok de genadeslag toebracht, maar de introductie van het 'Hammerklavier' heeft onomstotelijk veel invloed op het veranderende karakter van de muziek gehad. Ook kan men denken aan nieuwe procédés als het gebruik van betekenisloze woorden in de futuristische poëzie of aan de écriture automatique van de surrealisten; deze voorbeelden zijn in groten getale aan te voeren.

Kuhn wijst erop dat degenen die in de wetenschap voor een beslissende wending zorgen vaak jong zijn, of relatieve buitenstaanders, die nog niet dusdanig in het bestaande paradigma zijn ingevoerd of geschoold dat ze er niet meer uit kunnen treden. ${ }^{15}$ Evenzo kwam de belangrijkste vernieuwing in de Franse classicistische schilderkunst aan het eind van de achttiende eeuw, het toonaangevende schilderij De eed van de Horatiërs $(1784$ ) van Jacques-Louis David, tot stand na een jarenlang verblijf van de schilder in Rome. Toen T.S. Eliot in I9Is debuteerde met The Love Song of J. Alfred Prufrock en andere gedichten, was hij pas een jaar in Engeland. Picasso vervaardigde Les demoiselles d'Avignon (1907), dat nu algemeen gezien wordt als eerste uiting van het kubisme, op vijfentwintigjarige leeftijd en Rimbaud ( $\left.1854^{-1} 89 \mathrm{I}\right)$ schreef zijn destijds revolutionaire gedichten tussen zijn vijftiende en zijn eenentwintigste. Ook hier lijkt Kuhns theorie ter zake.

Als gezegd ziet Kuhn opeenvolgende paradigma's als systemen die niet neutraal, vanuit een hoger standpunt beoordeeld kunnen worden, en soms zelfs als totaal verschillende wereldbeelden. Bij de overgang van het ene paradigma naar een ander is sprake van een Gestalt-switch: voortaan ziet men iets heel anders. ${ }^{16}$ Dat is in de kunsten evenzeer het geval. Wie de verschillende gedaanten beschouwt die Hamlet in de geschiedenis van het theater heeft aangenomen, moet vaststellen dat slechts de intrige van het stuk en de naam van de hoofdpersoon zich hand- 


\section{Over het maken van revolutie}

haven. Zo vertolkt Hamlet in de loop der tijd de rol van een morele actor in een zeventiende-eeuws kosmologisch wereldbeeld, van een personage uit een stuk dat beter gelezen kan worden dan opgevoerd (bij een romantisch criticus als William Hazlitt), van een schurk (bij Wilson Knight), een moreel neutrale existentialist (bij Jan Kott) tot die van een ironische, twijfelzuchtige postmodernist in veel recente uitvoeringen. Die rollen mogen vergelijkbaar zijn op grond van het origineel, ze krijgen gestalte vanuit een volstrekt ander wereldbeeld en vanuit onverzoenbare theateropvattingen. R. Jarrell schreef in het essay 'The Obscurity of the Poet':

\section{[...] when the old say to us, "What shall I do to understand Auden (or Dylan Thomas, or whoever the latest poet is)?' We can only reply: 'You must be born again.' 17}

Het mag duidelijk zijn dat in Kuhns beschrijving van wetenschappelijke revoluties de sociale context van een verandering voorop staat; het gaat in eerste instantie om gedeelde waarden en uitgangspunten van groepen en gemeenschappen. Een dergelijke beschrijving werpt ook haar vruchten af op het terrein van de kunsten. Zo schrijft Rodenko met betrekking tot twee grote omwentelingen in de Nederlandse poëzie, die van de Tachtigers en die van de Beweging van Vijftig, dat de revolutionaire en anarchistische gezindheid van de individuele dichters eigenlijk niet zo relevant is:

Kloos stond niet alleen, evenmin als Lucebert. Fenomenologisch is juist het merkwaardige van zulk een magische vernieuwingsperiode dat er plotseling een nieuw klimaat is, dat een hele reeks dichters zich plotseling van een nieuw idioom bedient zonder dat men kan zeggen dat die-en-die ermee begonnen is. Meestal vormen deze nieuwe dichters niet eens een gesloten groep: zij gáán die pas vormen op grond van de ontdekking dat zij bezig zijn verwante dingen te schrijven. ${ }^{18}$ 
Bij een revolutie in de betekenis van Kuhn kan men zich afvragen wat mensen ertoe brengt zich tot een nieuw paradigma te bekeren. Omdat Kuhn meent dat argumenten hierin juist een veel kleinere rol spelen dan wordt aangenomen, besteedt hij er in The Structure of Scientific Revolutions niet al te veel aandacht aan. Behalve het argument dat een algemeen erkend, onoplosbaar probleem met behulp van een nieuw vocabulaire plotseling toch kan worden aangepakt, gaat het volgens hem verder hoofdzakelijk om persoonlijke en 'esthetische' overwegingen, waarbij het nieuwe paradigma als eleganter, geschikter en eenvoudiger wordt voorgesteld. ${ }^{19}$

Daar vooruitgangsbegrippen de laatste twee eeuwen belangrijk zijn voor onze interpretatie van culturele ontwikkelingen, ligt het voor de hand dat dergelijke begrippen ook in het soort discussies zijn gaan figureren dat zich rond revoluties aftekent. Wanneer iets als vooruitgang wordt gepresenteerd, krijgt het namelijk zowel een onvermijdelijk als een normatief karakter. Aan dit alles ontleent het vooruitgangsconcept een enorme retorische kracht.

Gezien het feit dat Kuhn dit concept in de geschiedenis van de wetenschap sterk heeft gerelativeerd, voor zover althans vooruitgang als een rationeel proces wordt opgevat, is het begrijpelijk (hoewel allerminst noodzakelijk) dat hij het gebruik ervan binnen het soort discussies dat hij beschrijft niet gethematiseerd heeft. In welke mate vooruitgangsargumenten echter als overtuigingsstrategie bij wetenschappelijke revoluties in praktijk worden gebracht, is hier niet aan de orde. Bij artistieke revoluties lijkt zo'n hypothese in ieder geval vruchtbaar. Gebruik van het vooruitgangsbegrip slaagt er hier in elke kritiek op vernieuwingen de pas af te snijden, omdat, zoals Gombrich het uitdrukt, 'sich im Fortschritt der unwiderstehliche Drang einer überlegenen oder göttlichen Gewalt manifestiert'. ${ }^{\circ}$ In Kuhns The Essential Tension staat ten aanzien van de kunsten overigens één zin die het belang van vooruitgangsgedachten overweegt, zij het niet als retorisch wapen bij een revolutie:

Since the Renaissance at least, this innovative component of 
the artist's ideology [...] has done for the development of art some part of what internal crises have done to promote revolution in science. ${ }^{21}$

Misschien roept de vooruitgangsideologie een artistieke revolutie op, maar het is een moeilijk te bewijzen stelling, waaraan in het slothoofdstuk nog enige aandacht zal worden besteed. Vooralsnog letten we vooral op de expliciet strategische toepassing van vooruitgangstermen bij artistieke veranderingen.

\section{Het vooruitgangsargument}

Eerder werden al enkele gevallen aangeroerd waarin het vooruitgangsargument gebruikt is. Schönberg bekritiseerde de terugkeer van de kleine Modernsky naar het verleden en later deed Adorno het met vergelijkbare argumenten nog eens over. Hoe gebruikelijk zo'n argumentatie is, illustreert ook het genoemde opstel van Mulder. In haar ontmaskering van Adorno's aanval op Stravinsky bedient ze zich op haar beurt van een dergelijke strategie, door Adorno angst toe te schrijven voor het nieuwe - de my thische dimensie van de inhoud namelijk - dat in de Sacre zo onheilspellend zou worden aangekondigd. Adorno tracht hier, aldus Mulder, 'gewapend met wetenschappelijke theorie, uit pure onmacht het nieuwe [...] te vernietigen'.22

Willem Pijpers eerder genoemde verwijt is in dit licht ook enige aandacht waard. Pijper had Schönbergs werk goed bestudeerd en componeerde zelf een tijdlang met behulp van een twaalftoonsysteem, wat begrijpelijk maakt waarom hij in deze muzikale controverse tegen Stravinsky partij koos en de muziek van Schönberg als vooruitgang in de muziek bestempelde. De componist en musicoloog Hendrik Andriessen schreef hierover:

Ik heb het altijd een zwak moment bij Pijper gevonden. [...] De theorie der progressiviteit verdient in het belang der muziek grondig herzien te worden. [...] Dat Strawinsky het ri- 
sico neemt, niet modern te zijn naar de opvatting zijner belagers, is in hem volkomen te prijzen. Het risico is edeler dan de zorg om zoveel mogelijk aan nieuwe eisen te voldoen. Een componist is pas echt modern als hij alle risico neemt en vast gelooft in de oorspronkelijke eisen van evenwicht en zelfstandigheid van ieder werk. ${ }^{23}$

Het is opvallend dat Andriessen zich in zijn kritiek op het vooruitgangsbegrip evenmin geheel aan dit begrip kan of wil onttrekken, want hij schermt zelf met 'moderniteit'; in de op dit citaat volgende alinea verdedigt hij zich zelfs tegen de denkbeeldige beschuldiging als zou hij in deze kwestie reactionair zijn. Andriessen keert zich zijns ondanks niet tegen de 'theorie der progressiviteit', zo valt tussen de regels te lezen, maar wil Stravinsky verdedigen tegen de volgelingen van Schönberg. Vlak boven het aangehaalde fragment karakteriseert hij hun muziek als 'nieuwe dogmatiek' en noemt hij hun ideeën 'artistiek beschouwd niet eersterangs', waarbij mogelijk ook de niet in twaalftoonmuziek geïnteresseerde componist in hem spreekt.

Om nog één voorbeeld te noemen: het in de vorige paragraaf vermelde citaat van Rodenko, dat een historisch commentaar op vernieuwingen in de kunst lijkt te zijn, is tegelijkertijd een vorm van propaganda die impliciet van vooruitgangscategorieën uitgaat. Waar deze belangrijkste pleitbezorger van de Beweging van Vijftig namelijk vermeldt 'dat er plotseling een nieuw klimaat is', beschrijft hij niet alleen zo'n klimaat vanuit onpartijdige distantie, maar is hij op hetzelfde moment ook doende zo'n klimaat voor de Vijftigers te vestigen. Aan zijn hier vlak boven te berde gebrachte stelling dat de poëzie 'haar eigen ontwikkeling volgt, onafhankelijk van de dichters, waarin zij zich verwezenlijkt' vallen precies dezelfde twee aspecten te onderscheiden; Rodenko makt hier van het heden het verleden van de toekomst.

Deze voorbeelden geven aan dat vooruitgangsbegrippen een niet te onderschatten retorisch wapen kunnen vormen om artistieke veranderingen in een bepaalde, gewenste richting acceptabel te maken voor buitenstaanders en voor het publiek. Artis- 


\section{Over bet maken van revolutie}

tieke revoluties worden daarom, al dan niet bewust, voorgesteld als goed, noodzakelijk en begrijpelijk. Goed in de betekenis van mooi, interessant, nuttig, maatschappelijk relevant, troostend, cognitief verrijkend, enzovoort, al naar gelang van de tijd en de context waarin die veranderingen plaatsvinden. Noodzakelijk in een (hegeliaans) logische zin, volgens de regelen der dialectiek; of positivistisch, met een beroep op empirische wetmatigheden; of metafysisch op de romantisch-revolutionaire manier die in het begin van het vorige hoofdstuk genoemd werd. En begrijpelijk in die mate dat de revolutionaire voorstelling van zaken overtuigend dient te worden gepresenteerd, met een theoretische verantwoording.

De manier waarop artistieke veranderingen worden voorgesteld heeft in alle drie de opzichten een historische lading. Om dit te begrijpen moeten we ons om te beginnen realiseren, dat naarmate we dichter bij het heden komen, het verleden een steeds grotere rol is gaan spelen. De musea zijn in de eerste plaats historische overzichten, de literatuur die gelezen wordt, bestaat voor een aanzienlijk deel uit klassieke werken van de afgelopen eeuwen en anders wel uit romans, gedichten, essays en verhalen die over het verleden gaan dan wel literatuur uit het verleden als uitgangspunt nemen. Er wordt, althans in de klassieke muziek, bijna geen concert uitgevoerd, of het laat componisten uit het verleden klinken - doorgaans in chronologische volgorde gerangschikt. Het theater voert nog altijd de klassieke stukken op, of laat zich er in nieuwe stukken door inspireren. Steeds worden de oude, klassieke films weer vertoond. We documenteren het verleden van de kunst, we reproduceren en interpreteren het en begrijpen het als context voor de kunst die nu gemaakt wordt. Bovendien laat kunst zich in deze eeuw niet alleen inspireren door werken uit het verleden, maar er wordt ook steeds meer expliciet (en bewust) uit geciteerd.

Dit alles staat niet los van de manier waarop we de tijd in algemeen opzicht beleven. In haar Huizinga-lezing van 1989, Traditions of the New, beschrijft Susan Sontag overtuigend hoe het bewustzijn van de westerse cultuur de laatste tweehonderd jaar steeds meer gekenmerkt wordt door eclecticisme en historisch 
zelfbesef. Volgens Sontag zien we onszelf in de geschiedenis optreden 'als speler en toeschouwer, als inwonend en op doorreis'. ${ }^{24}$ Met andere woorden, we beschouwen de tijd waarin we leven van dichtbij, maar tegelijkertijd met historische distantie; met een vergrootglas en met de omgekeerde verrekijker.

In hoofdstuk $\mathrm{r}$ is erop gewezen hoe sinds het einde van de achttiende eeuw de werkelijkheid in een historisch perspectief is komen te staan, dat Koselleck met het begrip geschichtliche Zeit heeft gekarakteriseerd. Het feit dat artistieke veranderingen als goed, noodzakelijk en begrijpelijk worden voorgesteld, krijgt in het licht van Kosellecks interpretatie duidelijke contouren. Zo bewerkstelligt het besef van een open toekomst een actieve opstelling van wie zich bij kunst betrokken voelt; de idealen die de kunsten zich stellen zullen geen werkelijkheid meer worden met het aanbreken van de jongste dag, maar moeten door menselijke - artistieke - inspanningen steeds weer bevochten worden. Men kan, en moet dus, ingrijpen in de loop van de geschiedenis van de kunst, teneinde een betere toekomst mogelijk te maken.

Daarnaast manifesteert zich het besef van een Gleichzeitigkeit des Ungleichzeitigen, het voortdurende gevoel dat de ene kunsttak zich reeds verder heeft ontwikkeld dan een andere, dat een bepaald genre in een ander land voorligt op de ontwikkelingen in het eigen land of dat men omgekeerd vooroploopt ten opzichte van achterblijvende kunstenaars elders. Deze dynamiek van gelijk geachte ontwikkelingen die in een verschillend tempo plaatsvinden, bepaalt in hoge mate het psychologische klimaat in de kunsten en de manier waarop veranderingen worden ervaren.

Maar het is de vraag of de geschiedenis op dit gebied als magistra vitae zoveel terrein heeft verloren (de derde in hoofdstuk I genoemde eigenschap van het concept geschichtliche Zeit), dus of het verleden niet meer een verzameling exempels is, wat volgens Koselleck in algemeen opzicht de moderne tijdsbeleving ontkent. In de kunsten valt zo'n afscheid van een exemplarisch verleden minder ondubbelzinnig aan te wijzen. Hier spelen de grote werken uit het verleden als voorbeelden nog altijd een niet 


\section{Over het maken van revolutie}

te onderschatten rol, zoals Kuhn ook al onderstreepte. Het is precies deze voor de kunsten typische kijk op het verleden, deze historia magistra artis, die velen tot scepsis over vooruitgang in de kunsten heeft gebracht. Is er na Bach ooit mooiere muziek gecomponeerd, luidt dan de achterdochtige vraag, of: welk boek heeft ooit de Don Quichot kunnen evenaren?2s Dat neemt niet weg dat ook in de kunsten historische concepten in de vorm worden gegoten van wat Koselleck een Kollektivsingular heeft genoemd, waarbij samenhangende processen onder een enkelvoudige noemer worden gebracht, al is dat misschien op een meer bescheiden schaal dan in andere culturele domeinen als wetenschap of techniek. 'De voortgang van de Europese muziek na Wagner' is geen uitzonderlijke uitdrukking.

Ten slotte wordt de moderne tijdsopvatting bepaald door wat Koselleck beschrijft als een toenemende spanning tussen ervaringsruimte en verwachtingshorizon. Een gelaagd verleden wordt vanuit het heden vorm gegeven, terwijl de toekomst op een andere manier wordt ervaren, losser van de reeds opgedane ervaringen en verweven met verwachtingen die een pragmatische dimensie met zich meebrengen van, in dit geval, kunsthistorische begrippen. In een dergelijk tijdsbewustzijn ontstaan benamingen van stromingen, de '-ismen', die een normatieve lading beginnen te krijgen.

Uitgaande van de hier weergegeven historische tijdsbeleving wordt het duidelijk waarom artistieke revoluties die als goed, noodzakelijk en begrijpelijk worden voorgesteld, in termen van vooruitgang beschreven en begrepen worden. Het vooruitgangsbegrip is als Kollektivsingular een van de centrale historische categorieën en bij uitstek bruikbaar om de veranderingsbegrippen, ook in de kunsten, een pragmatische dimensie te geven.

Wanneer anderen tot verandering van normen en uitgangspunten moeten worden overgehaald, bestaat een van de meest overtuigende argumentatiestrategieën eruit, die anderen te laten zien dat deze verandering een vorm van vooruitgang is. Dat lijkt een open deur, maar door de dynamiek en de potentie van het vooruitgangsbegrip is dat maar ten dele zo. Wanneer nieuwe kunstwerken na een artistieke revolutie beter heten te zijn, zijn 
ze niet mooier, nuttiger, maatschappelijk relevanter, troostender of cognitief meer verrijkend dan andere, maar dan eerdere kunstwerken. Die eerdere kunstwerken hebben door deze tijdelijke dimensie op dat moment reeds grotendeels afgedaan, waarbij van intrinsieke kwaliteiten kan worden afgezien. En dus van inhoudelijke argumenten (die in feite door de onvergelijkbaarheid van de verschillende codes, paradigma's of normsystemen toch al weinig zouden kunnen uitrichten). Zo verzette de musicus en musicoloog J. Chailley zich tegen protagonisten van de twaalftoonmuziek. 'Geen ogenblik,' zo schreef hij,

rechtvaardigt de dodecafonist zijn beginselen. Hij valt het traditionalisme aan en beroept zich op de noodzaak van richting te veranderen, zonder ook maar eenmaal te stellen, dat de door hem gekozen richting de goede is. Waarna hij zonder enige overgang de wettigheid bewezen acht van de postulaten, die hij eigenmachtig 'regels' of 'wetten' noemt. 26

'Beter' wil zeggen dat we verder zijn gekomen en dat wie zich van oude regels, normen of codes nog iets aantrekt, terugkeert en precies daarom te kort schiet, zoals het voorbeeld van de discussies over Stravinsky liet zien. De revolutie wordt om deze reden ook voorgesteld als een noodzakelijke gebeurtenis, die een conservatief kunstliefhebber of kunstenaar kan betreuren en waarvan hij de acceptatie soms zelfs uit kan stellen, maar die onafwendbaar is op grond van bepaalde historische wetmatigheden. Die wetmatigheden kunnen, als gezegd, in een dialectische vorm zijn gegoten, meer empirisch worden beargumenteerd of in een metafysisch revolutiejargon worden verwoord, maar steeds zullen ze er een verklaring voor moeten geven dat de geschiedenis nu eenmaal de loop heeft genomen die tot de onderhavige veranderingen heeft geleid. Daarom legt de kunst de laatste eeuwen steeds meer theoretische verantwoording af; kunstenaars legitimeren hun werk door te laten zien dat het van deze, hun eigen tijd is, dat het de tijdgeest weergeeft en daarom 


\section{Over bet maken van revolutie}

niet anders kan zijn dan het is.

De veranderingen dienen ook begrijpelijk te worden gemaakt in pamfletten, manifesten, kritieken, openbare bijeenkomsten en tentoonstellingen. En niet te vergeten: met schandalen, die soms zonder opzet ontstaan, zoals grotendeels bij de première van de Sacre, maar ook vaak bewust worden geprovoceerd, zoals door de dadaïsten. ${ }^{27}$ Aldus probeert men eerst de aandacht op zich te vestigen. Daarna moet er ook een aantal dingen worden uitgelegd, en dat kan met behulp van de geschiedenis. Bij dergelijke propaganda beperken de revolutionairen zich er niet toe de genoemde historische wetmatigheden te construeren, maar proberen ze ook een daarbij behorende voorgeschiedenis te ontwerpen, waarin uit het enorme reservoir van het verleden kan worden geput om directe voorgangers aan te wijzen en zo de vereiste 'ervaringsruimte' vorm te geven. Telkens zien we dan ook nieuwe stromingen en bewegingen teruggrijpen op een 'veronachtzaamde' periode uit het verleden, of het nu om de Spaanse literaire Generatie van '27 gaat, die de vergeten barokdichter Góngora weer onder de aandacht bracht, om de Arts and Crafts Movement van William Morris, die bij het kunstambacht van het voor-industriële tijdperk wilde aansluiten, of om de beeldende kunstenaars van de Pre-Raphaelite Brotherhood, bij wie deze voorgeschiedenis zelfs in hun naam doorklinkt.

In het begrijpelijk, en dus aanvaardbaar, maken van artistieke veranderingen blijkt telkens de voor vooruitgang vereiste lineaire tijdsopvatting voor te komen. Metaforen als een 'stap zetten', een 'sprong vooruit', 'richting', het 'juiste spoor' mogen door hun vanzelfsprekendheid nauwelijks opvallen - ze ontbreken maar zelden.

Zoals in het vorige hoofdstuk al werd vastgesteld, wordt bij een artistieke revolutie niettemin tegelijkertijd vaak de brenk met het verleden beklemtoond, om aan te geven dat er geen compromissen kunnen worden gesloten met het tot dan geldende normensysteem. Een nieuwe stroming of beweging kan haar eigen artistieke idealen beter begrijpelijk maken door ze af te zetten tegen wat gangbaar is. Daartoe wordt het heden failliet verklaard en in die aandacht voor het heden wordt de huidige 


\section{Steeds mooier}

tijd historisch en verglijdt aldus naar een verleden om ruimte te maken voor het nieuwe. We zien bij vernieuwingen in de kunsten dan ook veelvuldig een dubbele strategie ten opzichte van het verleden: het recente verleden (dat voor anderen nog heden is) wordt verworpen, terwijl op een meer afgelegen verleden een beroep wordt gedaan. Dit verder weg gelegen gebied wordt dan anders ingericht, om de noodzakelijkheid en begrijpelijkheid van de te bevechten omwenteling overtuigend vorm te geven.

Het verzet tegen de heersende normen en codes is op momenten van verandering doorgaans zo sterk dat de kunsthistoricus Gombrich zelfs meent dat

het niet zozeer de gemeenschappelijke idealen [zijn] die een periode bepalen alswel de gemeenschappelijke antipatbieën. Die antipathieèn laten de jonge kunstenaar gelukkig nog voldoende ruimte om te doen wat hij wil - goed of slecht mits hij de sociale verboden niet uit het oog verliest. ${ }^{2} 8$

Nochtans is een dergelijke observatie hoofdzakelijk bepaald door een contemporaine blik; achteraf valt er altijd een nieuw artistiek paradigma te bespeuren, omdat anders een periode of beweging niet kan worden herkend en als zodanig dus helemaal niet zou bestaan.

Er dient hier tot slot nog een aanvullende reden te worden genoemd waarom vooruitgangsargumenten zo vaak in de kunst zijn toegepast. Waar namelijk over culturele en maatschappelijke veranderingen in algemene zin wordt gediscussieerd, gebeurt dit eveneens, en deels op bovenbeschreven gronden, in termen van vooruitgang. Wie dergelijke veranderingen bepleit, ziet de kunst vaak als voorhoede van de maatschappij, als verkenner in maatschappelijke en culturele processen. Uit hoofdstuk 3 bleek dat een dergelijke opvatting vooral de boventoon voert bij avantgardistische bewegingen, die immers de scheidslijn tussen kunst en leven proberen op te heffen. Een geprononceerd voorbeeld zijn de surrealisten in Frankrijk, die een universele mentale revolutie met vergaande maatschappelijke gevolgen voorstonden. In de propaganda voor een surrealisti- 
sche revolutie gingen utopisch-socialistische ideeën en historisch-materialistisch gedachtengoed samen met een ambitieus programma 'ter bevrijding van het onbewuste', waarbij het esthetisch handelen voorop stond, als middel en als doel. Ook in de negentiende eeuw vinden we herhaaldelijk een pleidooi voor vooruitgang in de kunst als deel van of motor voor maatschappelijke vooruitgang, bijvoorbeeld in de Arts and Crafts Movement.

\section{Het museum van de periodisering}

Ondanks de geregelde herschikking van het meubilair uit het verleden krijgt de geschiedenis van de kunsten toch geleidelijk een vastere vorm. Die vorm is in grote lijnen in de negentiende eeuw ontstaan; vóór de negentiende eeuw werd er nog nauwelijks gesproken in termen van stijlperiodes als barok en renaissance, laat staan van een geordende opeenvolging van zulke periodes. In 178 I bracht Christian von Mechel een nieuwe ordening van schilderijen aan in de Gemäldegalerie van het Belvédère-slot in Wenen. In plaats van de gebruikelijke ordening naar onderwerp en formaat liet hij ze in een chronologische volgorde en in verschillende scholen gegroepeerd ophangen. ${ }^{29}$ Ruim een halve eeuw later, zo zagen we in het vorige hoofdstuk, publiceerde F. Kugler een van de eerste geschiedenissen van de beeldende kunst. Nu ging de geschiedenis van de hele wereld vanaf de prehistorie meetellen, een historie waarin de kunst niet als bij Hegel haar voltooiing in de eigen tijd bereikte om zichzelf vervolgens op te heffen. In de literatuurgeschiedenis en in de geschiedenis van de muziek begon gedurende de negentiende eeuw een vergelijkbare ontwikkeling. Analoog aan deze wetenschappelijke activiteit ontstond wat later geleidelijk ook onderwijs in de geschiedenis van de kunsten en aldus sedimenteerde er een canon.

Inmiddels is de geschiedenis van de kunsten een enorm museum, dat in de vorige eeuw gebouwd is, nadat in de achttiende eeuw al enkele fundamenten waren gelegd. De zalen van dit mu- 
seum worden geregeld opnieuw ingericht en het grootste deel van het gebouw bestaat uit later aangebouwde vleugels, maar de oorspronkelijke opzet, die de geschiedenis van de kunst in een aantal stijlperiodes verdeelt, wordt tot op heden nauwelijks aangetast.

Wie richt het museum in en wie bouwt er nieuwe vleugels aan, wie brengt met andere woorden deze periodisering tot stand? Dat zijn in beginsel de direct bij kunst betrokkenen, dus zij die de geschiedenis maken en actief deelnemen aan het 'kunstdiscours' - het geheel aan gesprekken, beweringen, uitingen, theorieën en reflectie dat actuele kunst hiërarchisch situeert. Tot deze deelnemers behoren naast de kunstwerken zelf (die, als gezegd, ook een rol in het discours spelen), de kunstenaars en wat verder weg de - niet al te theoretische - critici en andere bemiddelaars; galeriehouders, uitgevers, impresario's, subsidieverleners, conservatoren, adviseurs, tijdschriftredacties, enzovoort. Daarna komen de meer afstandelijke, theoretisch onderlegde critici, de kunstwetenschappers, de historici van de kunst, esthetici en, ten slotte, het publiek dat leest, luistert, kijkt en zich een mening vormt.

Dat het niet-professionele publiek hier de laatste plaats inneemt is geen uiting van avantgardistische Publikumsbeschimpfung. Het volgt slechts uit de constatering dat het publiek (althans het grote publiek) in zijn oordeel doorgaans het perspectief van de eerder genoemde groeperingen volgt. Dat is in de zogeheten populaire kunst en in de kunsten van de laatste decennia, waarin massacultuur en meer elitaire of 'hogere' cultuuruitingen zich steeds meer beginnen te vermengen, overigens veel minder het geval. De rol van het publiek is ontegenzeggelijk groter geworden en neemt nog steeds toe.

Nadat artistieke vernieuwingen in de kunsten door gezaghebbende direct betrokkenen zijn geaccepteerd, worden ze gecanoniseerd en kriiggen ze allengs meer aandacht van het publiek en van de wetenschappen. Het proces van historische situering en systematische plaatsbepaling ten opzichte van andere ontwikkelingen wordt door de laatste dan nog eens grondig overgedaan, maar opvallend genoeg zonder revolutionaire gevolgen 
voor de al bestaande inrichting van het verleden. De geschiedenis van de toekomst wordt in het heden door direct betrokkenen geschreven en later in grote trekken door de kunstwetenschappen uitgewerkt; historische beeldvorming is dus vooral een contemporaine en vooringenomen aangelegenheid. De plaats van het impressionisme in de kunstgeschiedenis of die van de naturalistische roman in de literatuurgeschiedenis is eerder door impressionisten respectievelijk naturalisten zelf ingenomen dan achteraf door onpartijdige historici toebedeeld. Zoals we zagen maken actoren in de kunsten geschiedenis in twee opzichten: door te handelen en door het eigen handelen te interpreteren en te situeren.

Dit geldt grosso modo voor de laatste twee eeuwen, maar natuurlijk niet voor oudere kunst: deze ontstond in een tijd waarin het bovenbeschreven historische bewustzijn, en dus de mogelijkheid tot periodisering in de door Koselleck geschetste geschichtliche Zeit nog niet bestond. Vanzelfsprekend werden de gebroeders Van Eyck in hun tijd als grote schilders beschouwd, maar ze eisten geen plaats in de geschiedenis voor zich op zoals bijvoorbeeld de abstracte expressionisten dat later zouden doen. Ze kregen een dergelijke plaats pas in de negentiende en twintigste eeuw.

Hoezeer de periodes en de canon op een gegeven moment ook vast blijken te liggen, de interpretatie van het verleden blijft toch veranderlijk. In zijn kunstsociologisch standaardwerk constateert Hauser terecht:

De ontstaansgeschiedenis van kunstwerken is bij lange na niet voltooid als hun makers ze uit handen geven. Kunstwerken gaan door met de metamorfose waaruit hun aanwezigheid bestaat, en ze krijgen niet alleen nieuwe, onvoorziene eigenschappen, maar ook een nieuwe betekenis die een eerdere generatie onbegrijpelijk zou zijn toegeschenen, en vaak zelfs vreemd. Historisch gesproken zijn ze nooit af en omdat ze niet voltooid tot aanzijn komen, verdwijnen ze ook niet voorgoed uit het gezichtsveld van de mensen. De ruimte van een museum of het hoofdstuk van een leerboek 
blijkt vaak veel te beperkt voor hen: ze bewegen zich onopboudelijk tussen geboorte, schijndood en renaissance. 30

Desalniettemin betreft dit eerder individuele kunstwerken en accentverschuivingen, die vaak het gevolg zijn van de eerder genoemde neiging tot het creëren van een voorgeschiedenis bij een te bewerkstelligen verandering, dan dat gesteld kan worden dat het algehele schema van de periodisering op de helling gaat. Wie kunsthistorische overzichtswerken uit het begin van de eeuw vergelijkt met recente overzichten, merkt op dat de universele structuur van de geschiedenis van de kunsten zelden onder vuur ligt.

Hauser mag gelijk hebben wanneer hij schrijft dat het dogma van de 'Periodizität' of dat van een geleding of kringloop in de geschiedenis, of van dialectische stadia, van een historisch lot, van voortdurende vooruitgang of van verval slechts variaties zijn op een geschiedfilosofisch mysticisme, maar in de praktijk hebben de deelnemers aan het kunstdiscours onophoudelijk gebruik gemaakt van zulke dogma's. ${ }^{31}$ En dan bij uitstek, zoals uit het voorgaande blijkt, van dogma's die met een of ander vooruitgangsconcept samenhangen.

Wie zich oriënteert op de geschiedenis, kan het klaarblijkelijk ook moeilijk zonder een enigszins stabiele structuur stellen. De behoefte aan historische situering blijkt vooralsnog onuitroeibaar. Ook de meest postmoderne en eclectische citatenrover wandelt het verleden binnen met een topografie in het hoofd. In feite geldt dit voor elke kunstenaar die een nieuwe plaats opeist. Hoe kan hij of zij revolutionair zijn en van vooruitgang getuigen, als er geen duidelijk verankerde traditie is ten opzichte waarvan de vernieuwingen pas betekenis krijgen?

\section{Vooruitgang als aporie}

Er rest een hinderlijk probleem, dat telkens opduikt wanneer het heden in zicht komt, een probleem dat als postmoderne verwarring zou kunnen worden omschreven. In dit hoofdstuk is 
een onderscheid gemaakt tussen twee soorten periodes. Ten eerste die waarin, analoog aan Kuhns 'normal science', sprake is van een geheel aan artistieke standaarduitingen die gelijk werden gesteld aan een systeem van normen, een 'periodecode' of een min of meer samenhangend aantal kenmerken van wat achteraf als stroming, beweging, generatie of paradigma wordt beschreven. Daarnaast werd gesproken van 'artistieke revoluties', waarin normen, standaardvoorbeelden, gangbare procédés en dergelijke plotseling veranderen. Het is op zichzelf niet heel bezwaarlijk dat dit een wat schematische voorstelling van zaken is, maar in de loop van deze eeuw wordt de afstand tussen het schema en de kunstpraktijken wel heel erg groot.

$\mathrm{Al}$ in het begin van deze eeuw zijn er geluiden te horen die als waarschuwing moeten worden opgevat voor een te ongebreidelde toepassing van het hier gebruikte schema. Zo verscheen in 1925 een boekje van de Weense kunsthistoricus Hans Tietze, Lebendige Kunstwissenschaft. Zur Krise der Kunst und der Kunstgeschichte, waarin aandacht wordt besteed aan de invloed van vooruitgangsgedachten in de kunst. Tietze, die een voorvechter van de moderne kunst in Oostenrijk was geweest en de jonge Kokoschka had gesteund, vroeg zich hier in een opstel over het expressionisme af hoe het toch kon dat iets dat tot stijl van de toekomst was uitgeroepen, na twaalf jaar weer als verouderd werd afgedaan. Hij betoonde zich sceptisch over de

polonaise van 'ismen', waarvan het steeds sneller wordende tempo tenslotte op het groteske uitliep: tussen voorjaars- en herfstsalon openden zich onoverbrugbare afgronden, de ontwikkelingsperiodes van de jonge genieën werden maandsgewijs bijgehouden en de werken zelf verouderden nog voor ze droog waren. 32

Tietze stelde een kwestie aan de orde die met het toenemend gebruik van vooruitgangsretoriek en met het verschijnsel van een steeds snellere afwisseling en opeenvolging van kunststromingen, bewegingen en generaties in de loop van deze eeuw voortdurend prangender werd. De invloedrijke vooruitgangs- 
ideologie van de avant-garde heeft bij de direct bij kunst betrokkenen een interpretatie doen post vatten van kunst als permanente revolutie: radicale vernieuwing wordt de belangrijkste bestaansgrond van elk kunstwerk en het eerste criterium voor de beoordeling ervan - en dus ook voor een historische situering. Daarmee dreigt het in dit hoofdstuk gemaakte onderscheid obsoleet te worden. Kunst wordt nog steeds historisch geïnterpreteerd, maar door het vervagen van de grens tussen 'paradigma' en 'revolutie' is een algehele verwarring ontstaan die veel weg heeft van het door Kuhn aangehaalde experiment met de veranderde speelkaarten. Aan de ene kant zijn vooruitgangsbegrippen zo vaak gebruikt dat ze inmiddels volstrekt betekenisloos en versleten zijn. Maar tegelijkertijd vormen ze, ondanks alle postmoderne munitie die zij te verduren hebben, een nog zo substantiële factor in onze tijdsbeleving, in onze interpretatie van en oriëntatie op hedendaagse kunst, dat reflectie op deze begrippen onvermijdelijk op een aporie uitloopt. Talloze geschriften die de laatste decennia van de hand van kunsttheoretici, historici van de kunsten, critici en kunstenaars zijn verschenen, ademen een dergelijke verwarring en spreken onophoudelijk van crisis, van het einde van de kunstgeschiedenis en zelfs van de kunst, zoals we bij Arthur Danto zagen. Het door de Duitse kunsthistoricus Belting geformuleerde probleem,

dass die heutige Kunst zwar die bekannte Geschichte der Kunst reflektiert, sie aber nicht 'nach vorn' fortsetzt, und [...] dass das Fach Kunstgeschichte heute kein verbindliches Darstellungsmodell geschichtlicher Kunst mehr zustande bringt

is representatief voor vele vergelijkbare uitingen van scepsis jegens de eens zo zorgeloos voortdenderende 'Freight Train of Art History'.33

Dit maakt de in dit hoofdstuk naar voren gebrachte onderverdeling in stabiele en revolutionaire periodes in de kunst niet zinloos, maar beperkt wel enigszins de actuele waarde ervan. Voor- 
uitgang lijkt soms op te lossen in een zo complex geheel van betekenissen en intuities, dat een nadere analyse van deze hedendaagse verwarring vereist is. Aan het eind van dit boek wordt aan deze kwestie dan ook nog de nodige aandacht geschonken. Hier ging het er in de eerste plaats om, het gebruik van vooruitgangsbegrippen in de laatste twee eeuwen onder de loep te nemen.

De kunstpraktijk kan natuurlijk in andere termen beschreven worden dan volgens het model van Kuhn. Zo is er de laatste jaren, met name door het werk van Bourdieu, veel belangstelling voor het perspectief van sociale distinctie. In deze benadering is het terrein van de kunsten het slagveld voor verschillende maatschappelijke lagen, die zich aldus door deelname en uitsluiting van elkaar kunnen onderscheiden. ${ }^{34}$ Een vergelijkbaar perspectief op de kunstpraktijk is dat van concurrentie. Het marktmodel verheldert dan de kunstproduktie en -receptie. Zo'n economisch perspectief is ook sociologisch relevant, aangezien menselijk handelen altijd - en in de kunsten niet minder - wordt gevoed door machtsstreven en geldingsdrang, waarbij bepaalde groepen steeds hun opvatting tot algemene opvatting willen maken. 35 Ten derde kan de kunstpraktijk gekarakteriseerd worden door te letten op het verwante mechanisme van selectie, dus de manier waarop kunstenaars en kunstwerken in een bepaalde hiërarchie worden geplaatst op grond van opleiding, publiek succes, subsidiëring, enzovoort.

Toch heeft het hierboven gebruikte, op Kuhn geïnspireerde model in dit geval het voordeel dat hierin het gebruik van vooruitgangsbegrippen verhelderd kon worden, omdat ze zich in de overgangsfase van het ene normensysteem of paradigma naar het andere duidelijker manifesteren, dan wanneer voor het perspectief van distinctie, concurrentie of selectie wordt gekozen. Ook in dit laatste perspectief zal blijken dat het vooruitgangsargument een veel gebruikt en succesvol middel is, maar de toepassing van deze strategie valt dan wellicht moeilijker met de ontwikkelingen in de kunst zelf te combineren.

De in dit hoofdstuk geschetste praktijk en de eerder beschreven geschiedenis van vooruitgangsbegrippen in de kunst zijn 


\section{Steeds mooier}

steeds met voorbeelden gelardeerd, maar die hadden vaak een incidenteel karakter. In hoeverre de hier ontwikkelde theorieën een adequaat beeld geven, is nog niet afdoende gekarakteriseerd. In de volgende twee hoofdstukken worden daarom twee voorbeelden in al hun complexiteit wat nauwkeuriger bekeken. Het eerste voorbeeld is een vernieuwing in de Nederlandse poëzie door de Beweging van Vijftig. Het tweede voorbeeld gaat over vernieuwing in de beeldende kunst en in de architectuur van enkele decennia eerder; de veranderingen die door De Stijl teweeg zijn gebracht. 



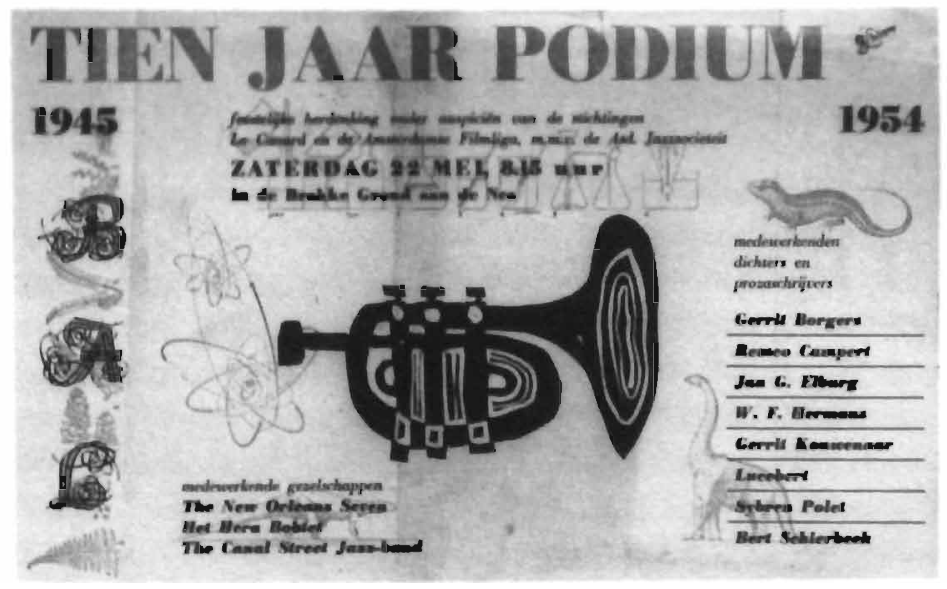

Bij tien jaar Podium 


\section{Vernieuwing in de poëzie: Podium en de Beweging van Vijftig}

maar je zult niet meer zo stevig staan op de treeplank van de tijd (Lucebert, 'trajekt')

\section{Na de oorlog}

Begin jaren vijftig verscheen in het tijdschrift Podium poëzie van bijna alle dichters die niet veel later als 'de Vijftigers' de literatuurgeschiedenis in zouden gaan. Eerst nam Podium gedichten van Paul Rodenko op, daarna, vanaf de vijfde jaargang (1949), van Sybren Polet, Simon Vinkenoog, Hans Andreus en Hugo Claus. In de hierop volgende jaargangen verschenen verder gedichten van Gerrit Kouwenaar, Lucebert en Remco Campert. $^{1}$

Podium is het belangrijkste tijdschrift geweest voor de doorbraak van de Beweging van Vijftig. Het periodiek publiceerde nieuwe, voor Nederland in die tijd zeer ongebruikelijke poëzie, die onderling sterk verschilde doordat de meeste dichters in hun net bevochten vrijheid hun individuele uitdrukkingswijze niet prijsgaven. Tenminste, achteraf bezien. Want een dergelijk perspectief valt niet automatisch samen met dat van toenmalige tijdgenoten. Zo schreef de met de nieuwe poëzie sympathiserende Podium-medewerker Hans van Straten in 1954 in een kritisch stuk over de Vijftigers dat je je eens voor moest stellen 'wat de lezer van 1964 of 1974 zal overkomen bij het doorbladeren van oude Podium-jaargangen. Ik denk, dat hij een beetje versteld zal staan over een dergelijke massale onpersoonlijkheid.'z

Wie dit nu, in I994, doet, verbaast zich eerder over die uitspraak dan over de veronderstelde eenvormigheid in deze poëzie. Maar wie zich, haast onvermijdelijk beïnvloed door enkele decennia selecteren, canoniseren en verguizen, niet tot lezing 
van deze gedichten beperkt, en ook kennis neemt van andere verzen uit die tijd en van het toen geschreven kritisch proza, zal Van Stratens uitlating niet meer zo zonderling vinden.

Leek de nieuwe poëzie destijds misschien niet homogeen omdat de voornaamste noemer waaronder ze werd beschouwd, in het feit schuilde dat ze zo anders was dan de gangbare? Is zij niet ook juist in de loop der tijd steeds verscheidener en persoonlijker geworden, omdat veel dichters uit deze beweging zich later zo verschillend en individueel ontwikkeld hebben dat dit nu ook in hun eerdere werk valt te herkennen? Wie het latere werk van zeg Kouwenaar of Campert goed kent, leest dat eerdere werk stellig anders dan de Podium-lezer van destijds. Die kon nog niet lezen wat nu in die gedichten is te bespeuren.

Bij het doornemen van oude Podium-jaargangen wordt ons een meer genuanceerde blik van binnen uit gegund op de ontwikkelingen in de poëzie van die jaren. Men beschouwt deze ontwikkelingen nu vrijwel unaniem als een periode van bloei. Het beeld is grofweg dat de poëzie in het slop was geraakt en dat de Beweging van Vijftig haar daar weer heeft uitgehaald. Dit algemene beeld veronderstelt, zo gauw men een historische benadering hanteert, bijna onvermijdelijk een bepaalde mate van (eventueel tijdelijke, of relatieve) vooruitgang. Alvorens daar verder op in te gaan eerst enkele woorden over die eerste jaren na de oorlog.

De sfeer van deze tijd wordt zowel achteraf als vanuit het toenmalig perspectief gekenmerkt door een algeheel gevoel van impasse. Het lijkt wel alsof de jongere generatie voor een muur staat, zo schrijft Paul Rodenko in 1947; 'maar wanneer er onder de jongeren zijn, die er geen neosymbolistische of pseudoduperroneske doekjes om winden, maar eerlijk voor hun onvermogen uitkomen, dan zou die eerlijkheid er toch op kunnen duiden dat bij hen misschien meer van een impasse dan van reële onmacht sprake is'. (Iv:3-4)

De in die jaren overal klinkende roep om verandering en vernieuwing, versneden met een algeheel gevoel van een in de oorlog failliet gebleken moraal en een desondanks verhevigd pogen tegelijkertijd weer de oude waarden te herstellen, vertaalt zich 
ook in de poëzie en de poëziekritiek. Volgens sommigen dient de dichtkunst zich te vernieuwen door zich maatschappelijk te engageren, hetzij in humanistische, hetzij in meer expliciet politieke zin. Anderen willen veranderingen in de vorm, waarbij vooral het sonnet het moet ontgelden. Verder wordt er verzet aangetekend tegen estheticisme, subjectieve lyriek en anderzijds ook tegen de meer cerebrale poëzie.

Aan de andere kant worden in die eerste jaren na de oorlog ook pogingen gedaan weer bij de traditie aan te sluiten. De te verwachten luide roep om vernieuwing, zo schrijft Vestdijk in 1945, zal hoofdzakelijk een retorische aangelegenheid zijn. ${ }^{3}$ En eerder in dat bevrijdingsjaar noteert (de dan nog onder het pseudoniem Frank Wilders schrijvende) Fokke Sierksma in Podium, dat het in de poëzie voortaan weliswaar anders moet en dat zij volop in het leven dient te staan, maar dat er eveneens dient te worden voortgebouwd op de oudere generatie - op Marsman bijvoorbeeld. 4

De jaren na 1945 vertonen niet alleen het beeld van een impasse - het gevoel te moeten vernieuwen zonder te weten hoe, de idee van stagnerende vooruitgang - maar vanuit een minder historiserend bewustzijn ook van een cultureel vacuüm. Er was een leegte ontstaan omdat velen niets meer zagen in de voor de oorlog gehanteerde literaire normen, die literatuur opleverden welke wel erg ver af stond van een door de oorlog veranderde mentaliteit. De werkelijkheid was niet meer als voorheen. De schok van de oorlog had bij wijze van spreken een aantal afwijkende kaarten aan het spel van cultuur en kunst toegevoegd, kaarten die verwarring stichtien aangezien ze nog niet eerder waren vertoond, zoals bij het in het vorige hoofdstuk genoemde experiment van Bruner en Postman. De kaart van de atoombom bijvoorbeeld, of de kaart van een aan de verzuiling voorbijgaand engagement tijdens het verzet, of de kaart van een voortaan prominent buitenland, dat het nogal in zichzelf gekeerde (in de Eerste Wereldoorlog neutraal gebleven) Nederland toch maar had bevrijd (en overvallen).

De ervaring van een vacuüm in de literatuur was verder te wijten aan het feit dat de voormannen van de gezaghebbende 
Forum-generatie niet meer leefden, terwijl uitgerekend zij hadden gewaarschuwd voor wat er ophanden was. Naast dit gezag zonder gezagvoerders bestond er bovendien een leegte in een veel concreter opzicht, doordat er in die tijd weinig geld en weinig mogelijkheden waren, bijvoorbeeld door de zelfs nog in 1948 heersende papierschaarste.s

Er werd in die jaren veel energie gestoken in een heroriëntering die dat vacuüm moest opvullen. Ook op andere maatschappelijke gebieden manifesteerde zich het streven naar culturele vernieuwing, vooral op het terrein van de politiek en de wetenschap, en wel bij verschillende generaties tegelijk. Een oudere generatie, die haar intellectuele vorming ruim voor de oorlog had gekregen, onderstreepte vanuit een hoofdzakelijk christelijk georiënteerd humanisme de noodzaak van een 'geestelijke wederopbouw', in politiek opzicht bijvoorbeeld in de vooruitstrevende 'doorbraakbeweging'; verder in de wetenschappelijke en maatschappelijke activiteit van de Utrechtse School. Dit was een groep filosofen, psychiaters, criminologen en pedagogen die een beroep wilde doen op de persoonlijke verantwoordelijkheid van individuen in een 'verinnerlijkt gemeenschapsleven'. 6

Vanuit een veel jongere generatie, deels in of vlak na de oorlog gevormd, klonk echter een heel ander geluid, en dan vooral in de literatuur. Een geluid van afkeer jegens elk moralisme, van een diep wantrouwen tegenover al die goed bedoelde idealen die zo'n enorme slachting toch niet hadden kunnen voorkomen. Het waren vooral de 'landerigen', zoals de literaire kritiek ze destijds noemde, de romanschrijvers Willem Frederik Hermans, Anna Blaman en Gerard (toen nog G.K. van het) Reve, die een volstrekt andere mentaliteit verwoordden, een geestesgesteldheid die wars was van een humanistisch optimisme waar in de ogen van die jonge generatie geen enkele grond meer voor bestond. 


\section{De Beweging van Vifftig: vooruitgang?}

Een algemene beschrijving van de ontwikkelingen in de Nederlandse poëzie tussen 1945 en 1960 is hier niet aan de orde; elders is daar al veel over geschreven. Uiterst waardevol en goed gedocumenteerd is wat betreft de opkomst van de Beweging van Vijftig Fokkema's Het komplot der Vijftigers uit 1979.7 In deze 'literair-historische documentaire' wil hij inzicht geven 'in de wijze waarop in werkelijkheid een nieuwe literaire generatie opkomt' (p.8). Niet in zoverre het de immanente ontwikkeling van de literaire structuur betreft, maar op basis van vers-externe uitspraken (p.220). Fokkema ontleent de titel van zijn boek aan een karakterisering door Christian Dotremont van de Cobrabeweging als 'een spontaan complot van subjectieve instellingen', een kenschets die Kouwenaar in 1972 ook voor de Beweging van Vijftig toepasselijk achtte (p.7-8, 4I, 165).

De verklarende suggestie van de titel, Het komplot der Vijftigers, intrigeert. De paradox tussen onbewuste spontaniteit en een bewuste rationele strategie wordt door Fokkema herhaaldelijk geill lustreerd, maar hij heeft weinig andacht voor reflectie op de vernieuwing. De theoretische gedachte die het empirisch materiaal moet samenvoegen blijft daardoor impliciet: Fokkema laat niet zien hoe een literaire generatie, maar één, namelijk die van de Vijftigers, opkomt. Zijn laatste hoofdstuk, waarin hij zeven kenmerken noemt van modernistische vernieuwingsbewegingen, sluit dan ook niet naadloos aan bij zijn tweehonderd bladzijden documentatie, omdat hij een algemener gezichtspunt op vooruitgang of vernieuwing in de kunst ontbeert of misschien ook te abstract vindt.

De benadering in dit hoofdstuk kan gezien worden als een empirische beschouwing vanuit zo'n meer theoretisch perspectief en dus als een aanvulling op het werk van Fokkema, waarbij ook aandacht aan de poëzie zelf ('de immanente ontwikkeling van de literaire structuur') zal worden besteed. In de eerste plaats is deze beschouwing echter een toetssteen en illustratie van wat ik in de voorafgaande hoofdstukken van mijn boek heb beweerd. 
Er is gekozen voor een strenge beperking van het empirisch materiaal om ook de meer theoretische aspecten van vernieuwing of vooruitgang in de kunst in dit kort bestek enig recht te kunnen doen. Daartoe wordt hier uitgegaan van de eerste tien jaargangen van Podium, als gezegd het belangrijkste tijdschrift voor de doorbraak van de Beweging van Vijftig. Bij het lezen van deze jaargangen dienen de volgende vragen als leidraad. Ten eerste is het natuurlijk van belang of men destijds zelf de onderhavige veranderingen in de poëzie als een of andere vorm van vooruitgang beoordeelde en - als dit al het geval was - waaruit dan volgens de toenmalige opvattingen deze vooruitgang bestond.

Ten tweede kan de vraag worden gesteld hoe met vooruitgang samenhangende begrippen (als 'modern', 'avant-garde', 'historische noodzaak' e.d.) retorisch werden gebruikt, welke rol ze feitelijk speelden in de sociaal-literaire context van die tijd. Vanuit zo'n vers-externe benadering, om de terminologie van Fokkema te handhaven, zal ook worden gelet op de strategie die een vernieuwingsbeweging in de kunst volgt om erkenning te krijgen (of om, vanuit een ander perspectief, de vooruitgang werkelijk gestalte te geven door de reële verandering van esthetische normen). Was, met andere woorden, de roep om vernieuwing slechts retorisch in de zin van Vestdijk, of ook retorisch op een verder gaande manier zoals die in het vorige hoofdstuk aan de orde kwam?

Naast deze twee vragen kan nog een derde vraag gesteld worden, die evenwel niet met het doornemen van die tien jaargangen kan worden beantwoord, maar die deze gevalstudie wel intrigerender makt: in welke mate beoordeelden latere critici en literatuurhistorici deze ontwikkelingen als vooruitgang; dus hoe kreeg de Beweging van Vijftig haar plaats in de literaire canon? Op die vraag zal aan het slot kort worden ingegaan. 


\section{Op de planken van het jonge Podium}

Naar aanleiding van het tienjarig bestaan van Podium verscheen in 1956 een bloemlezing uit de voorafgegane jaargangen, wat volgens redacteur Gerrit Borgers zeer ongebruikelijk was (een voor de hedendaagse, met bloemlezingen overvoerde lezer wellicht wat weemoedig stemmende observatie). Die ongebruikelijkheid ligt echter, zo merkt hij in de inleiding op, geheel in de lijn van het tijdschrift, dat juist op dit gebied zijn sporen heeft verdiend. ${ }^{8}$

Borgers overdrijft opmerkelijk weinig voor zo'n feestrede. Want hoezeer Podium in tien jaar ook verandert, het probeert vanaf het begin onophoudelijk - en met voortdurend succes non-conformistisch te zijn. Het karakter van het tijdschrift is, om nog eens wat andere in de jaren zestig en zeventig tot cliché versleten omschrijvingen te gebruiken, grensverleggend, alternatief, polemisch, maatschappelijk geëngageerd, normdoorbrekend (het meest geruchtmakend door de bijdragen van W.F. Hermans) en ruimte scheppend voor nieuwe vormen. Podium was binnen de literaire wereld wat de vpro twintig jaar later voor televisie kijkend Nederland zou zijn.

In de zomer van 1944 richtten enkele jongeren in Leeuwarden het illegale literaire periodiek Podium op om dichters een publikatiemogelijkheid te bieden en om het verzet (ook financieel) te steunen. Daarmee is Podium niet alleen clandestien, maar - als enige tijdschrift, merkt Borgers op - ook illegaal. 9 De eerste drie nummers bevatten uitsluitend poëzie. Pas in het vierde nummer, dat onmiddellijk na de bevrijding verschijnt, wordt een 'Doelstelling' gepubliceerd door Frank Wilders (zoals gezegd, pseudoniem van Fokke Sierksma). Hij eist hierin van de poëzie, dat die in het leven staat en niet ontaardt in een 'fijnwegerij van geintroverteerde gevoelens'. Sierksma wil voortbouwen op de oudere generatie - hij denkt daarbij aan dichters als Marsman en Roland Holst - maar het moet wel 'anders'. (I:54-57)

In het eerste nummer van de tweede jaargang komt de redactie (P. van den Burch, P. Kalma, P.P. Miedema, F. Sierksma, W. Hijmans) opnieuw met zoiets als een programma. Zij zet zich af 
tegen 'vaag-idealistische mensheidsidealen' en tegen de verheerlijking van het 'klein geluk'; dat is 'hoogstens aanvaardbaar als het veroverd werd in een storm'. Een windstilte wensten zij noch als schuilplaats noch als doel.

De poëzie 'is verschraald tot een armetierige lyriek - een impasse'. Podium verzet zich tegen 'aestheticisme': '[...] wat een dichter te zeggen heeft (is) interessanter en belangrijker [...] dan zijn dictie en techniek.' Daarom zal Podium ook een verbeten gevecht op politiek en sociaal terrein voeren, zonder zich al te veel van maatschappelijke etiketten aan te trekken: 'Wil men ons humanisten noemen, het is ons goed. Als het dan maar een humanisme met haar op de tanden is.' (II: I-3)

Als het aan de redactie van Podium ligt, zal de geest van $\mathrm{Fo}_{-}$ rum weer gaan waaien: er wordt, zo lijkt het, opnieuw voor de vent boven de vorm gekozen en men is bij wijze van spreken al weer naarstig op zoek naar een nieuwe Dirk Coster om zijn gal op te spuwen. In het volgende nummer beroept redacteur Peter van den Burch zich expliciet op Forum in zijn 'De Geuzen voor Den Briel', waarin hij zich tegen verschillende vormen van estheticisme afzet; tegen de lieftallige romantiek bijvoorbeeld ('Het zijn al bloemen en landliederen wat de klok slaat') en tegen de poëzie van Het Woord. ${ }^{\circ} \circ$

Dergelijke geluiden zetten zich tot in de vierde jaargang voort. Er verschijnt, afgezien van de gedichten van Achterberg, echter weinig opvallende poëzie in Podium, dat zich sceptisch betoont ten opzichte van zich aandienende vernieuwingspogingen. Zo staat in december 1946 in de rubriek De proppenschieter een persiflage op een 'experimenteel' gedicht dat Paul Rodenko kort daarvoor in Criterium had gepubliceerd. (III:63-64)

In oktober 1947 begint de vierde jaargang na een fusie met het tijdschrift Columbus en na de opheffing van Proloog, dat stopt vanwege de noodzakelijk geachte tijdschriftenconcentratie. ${ }^{11}$ Tot de redactie, waarop tot dan hoofdzakelijk Sierksma zijn stempel had gedrukt, treedt nu Columbus-redacteur Paul Rodenko toe. Rodenko is een relatieve buitenstaander, niet opgegroeid in een Nederlandse literaire traditie en goed bekend met 
de ontwikkelingen van de buitenlandse avant-garde.

In het eerste nummer van het vernieuwde Podium wordt een voortzetting van dezelfde richting aangekondigd. In 'Op zoek naar een programma' schrijft de redactie (naast Rodenko en Sierksma A. Wadman en G. Borgers) een weg te willen zoeken 'uit de huidige impasse en buiten de zogenaamde literatuur'. (Iv:I-2) Het zoeken van Podium biedt overigens zelf ook de aanblik van een impasse, of zoals iemand destijds opmerkte: 'Podium stelt zich ten doel, het zich ten doel stellen van een doelstelling.' ${ }^{2}$

\section{Van Sierksma naar Rodenko}

In de jaargangen IV tot en met vi is op het gebied van poëzie te zien hoe zich binnen Podium twee tendensen beginnen af te tekenen. Enerzijds Sierksma, die vernieuwing in het verlengde van de Nederlandse traditie voor ogen lijkt te staan en die vanuit de nuchterheid van Forum de zich aankondigende experimenten met wantrouwen beziet; anderzijds de tendens-Rodenko, die experimenten naarstig opzoekt en in huis probeert te halen.

De eerste tendens vinden we om te beginnen in een van de weinige gepubliceerde verzen van Sierksma, in het tweede nummer van de vierde jaargang (Iv:85), 'Bye-bye to those poets', waarin hij zich afzet tegen poëzie van onder andere Criterium en Het Woord:

Heren - het is de hoogste tijd.

Ledig versuft ww laatste glazen

en ga naar huis, de eenzaambeid

zal aaklig in uw oren razen.

De weg naar huis is lang en blind

en ov'ral liggen oude kranten, schrikachtig schuiflend in de wind.

De Muze heeft wél zwaarbezochte klanten. 
In 't ziekenhuis brandt altijd licht:

het leven wordt per streep gemeten.

Maar niettemin, in bet Gedicht

heeft God deez' aard vergeven ... en vergeten.

En is de Helicon te steil, een zachte helling in de Venusbergen glooit naar de Droom, sereen en ijl...

Een dommelende hond mag men niet tergen.

Alles is niets voor wie bemint

Schoonheid in glas, gedicht en rokken.

Hij die de (half)zachte Eenheid kent, glimlacht bij de banale brokken.

Maar voor $u$ gaat - hebt $u$ betááld?

Ook ik wil niet tellurisch dazen, maar ziet $u$ : 't wordt op anderen verhaald, op Petkovs, Gruners en dat genre dwazen.

In dit (overigens niet al te indrukwekkende) vers van Sierksma zien we vooral wat hij niet van de poëzie van zijn tijd verlangt. Hij vind dat veel tijdgenoten maar het veld moeten ruimen; 'het is de hoogste tijd'. Sierksma zet zich in deze strofen af tegen de van zelfmedelijden doortrokken ik-lyriek, tegen de levensmoede toon van veel gedichten, tegen stemmingspoëzie over de liefde, tegen het kleine geluk, tegen de droom als vlucht uit de werkelijkheid en tegen estheticisme. Enig vitalisme, waarbij hij wellicht aan Marsman denkt, doet het bij hem beter dan de (volgelingen van de) vermoeide Bloem, getuige bijvoorbeeld regel 17, die Bloems klein geluk van de Dapperstraat op de hak neemt. Maar niet alleen vitalisme, ook maatschappelijk engagement is voor de oud-verzetsman Sierksma essentieel, getuige zijn laatste strofe. Men moet bereid zijn te betalen, desnoods met het leven, en dat niet alleen aan anderen overlaten. ${ }^{13}$

In de eerste twee nummers van de vijfde jaargang schrijft Sierksma een essay over de poëzie van zijn tijd, 'Stand van za- 
ken' (I resp. II) waarin hij stelt dat de Nederlandse poëzie achterloopt bij de buitenlandse, onder andere de Franse dichtkunst. Zo is het surrealisme eigenlijk aan ons voorbijgegaan. Dat heeft echter wel ruimte geschapen voor persoonlijke vernieuwing bij dichters als Nijhoff en Achterberg. En bovendien zitten de Fransen nu alleen maar hun eigen surrealisme op te poetsen. In het kielzog van Vestdijk pleit Sierksma ervoor vernieuwingsdromen af te breken en bij de traditie aan te sluiten, en opnieuw verwerpt hij subjectieve lyriek en estheticisme. Wat hij wel wil, wordt echter niet zo duidelijk. Interpreterend lijkt het dat hij van poëzie steeds een getuigenis over de existentie van de mens eist, een uitdrukking van de condition humaine, die ook standhoudt in extreme situaties van leven en dood, waarbij de wereld van het verzet voor hem een ijkpunt blijkt. Hoe dat in poëzie vorm moet krijgen, blijft echter een raadsel..14 (Sierksma's belangstelling richt zich in Podium meestal ook meer op een christelijk-humanistisch discours van 'geestelijke wederopbouw', die onnavolgbare mengverhouding van theologie en cultuurbeschouwing die veel Nederlandse intellectuelen in de jaren na de oorlog zo in de ban hield.)

Hetzelfde, een heldere kijk op wat ongewenst is en een onzekere houding over hoe het wel zou moeten, zien we terug in Sierksma's eerste uitlatingen over de experimentelen. In "Atelierrevolutie' bespreekt hij het periodiek van de Experimentele Groep in Holland, Reflex. 's Te midden van de experimentele schilders van deze groep, die hetzelfde jaar nog in Cobra overging, bevonden zich de latere Vijftigers Jan Elburg, Lucebert en Gerrit Kouwenaar.

Reflex wil volgens Sierksma de formalistische kunst, die abstractie boven levendige uitdrukking stelt, afschaffen en daarmee de op klassenonderscheid berustende dualismen tussen vorm en inhoud en kunstenaar en volk om zeep helpen. Bovendien vinden de Experimentelen de artistieke uitdrukkingen van kinderen en volkskunst van groot belang.

Sierksma's aarzelende sympathie voor dit revolutionaire elan wint het niet van zijn Forum-scepsis. Iets dergelijks wordt ook door Podium beweerd, stelt hij (met het oog vooral op dat for- 
malisme, waarschijnlijk). Maar het is hier allemaal zo klungelig verwoord! En dan die lelijke verzen van Elburg en Lucebert Sierksma vindt het maar niets. Hij gelooft niet echt in een revolutie en besluit met de verzuchting: 'Wij zijn alleen maar berooide repetitoren. Wij repeteren alles, zelfs de revoluties van onze voorgangers.'

$\mathrm{Na}$ dit stuk, dat de revolutionaire vernieuwing in de poëzie (in een zeer vroeg stadium) afwijst, zal Sierksma niet meer over dichtkunst in Podium schrijven. Alleen een jaar later haalt de redactie een sceptisch bon-mot van Roland Holst over de langharige, vaak in meer dan één trui gehulde Lucebert aan: 'Ik begrijp niet waarom die jongelui zich, als ze poëzie gaan voorlezen, zo warm aankleden.' Is dit nog de hand van Sierksma? ${ }^{16}$

De tendens-Sierksma, die van scepsis over de in gang gezette vernieuwing, blijft overigens in Podium bestaan in de stukken van Hans van Straten, zoals in de aanhef van dit hoofdstuk al bleek en ook hieronder nog aan de orde zal komen.

Paul Rodenko marcheert eind 1947 Podium binnen met het opstel 'Verzoening met de Soldaat', een nu nogal gedateerd aandoende confrontatie met onder andere het erfgoed van Ter Braak over de rol van de Dichter. (Iv:3-14) Of hij met dit theoretische stuk afrekent met de door 'armetierig conservatisme' beheerste impasse, is de vraag, maar hij weet er in ieder geval een (van Forum-casuistiek doortrokken) polemiek mee aan te zwengelen. Deze lijkt echter ver te staan van wat jongere dichters bezighield. Rodenko's aanvankelijke steun voor deze dichters is vermoedelijk substantiëler in het plaatsingsbeleid van de redactie, die in de vijfde jaargang gedichten van Polet, Vinkenoog, Andreus en Claus opneemt. Een concreet voorbeeld laat zien wat voor verzen er in 1949 in Podium kunnen worden aangetroffen. Neem Hans Andreus' 'Op de berg matoe' (v:353):

op de berg matoe

mogen alle mensen wonen

ze zullen er werken en eten

en de vrouwen krijgen er zonen 
Vernieuwing in de poëzie: Podium en de Beweging van Vifftig

van prachtig geweldig hout

en dochters als zuivere kanoos

en iedereen zal er lachen

en iedereen zal er zingen

want het hart wordt zichzelf niet moe

op de reusachtige berg matoe

Weliswaar treffen we hier nog wel enig eindrijm, maar dat zegt niet zoveel over vernieuwing (en bovendien was er al genoeg in vrije verzen geschreven, ook voor de oorlog). Wat opvalt, is een andere, lichtere, haast kinderlijke toon en een ander soort beeldspraak; houten zonen en 'dochters als zuivere kanoos'. Zie ook de eerste regels van Rodenko's eigen 'Het beeld' dat later in dezelfde jaargang (v:s I s) verscheen:

\section{Uit bet hout van de morgen}

wit morgenrozenhout

sneed ik een beeld

beel licht en smaller dan een lijsterstem

een beeld van morgenrozenhout.

Dergelijke regels verschillen wel zeer van bijvoorbeeld Sierksma's hierboven aangehaalde poëzie: ze hebben geen ondubbelzinnige boodschap of eenvoudig aan te geven expressieve waarde, noch beelden zij de (of een) werkelijkheid af. Eerder krijgt het beeld zelf pas gestalte binnen de taal van deze poëzie, die daarmee veel autonomer is geworden dan tot dan toe gebruikelijk was.

Pas ver in de zesde jaargang laat Rodenko zich kritisch uit over de huidige Nederlandse poëzie naar aanleiding van De Windroos-serie, de beroemd geworden poëziereeks onder redactie van Ad den Besten. Deze serie kan volgens hem de culturele impasse doorbreken, nu het 'Tijdperk van Verzamelde Werken' is afgesloten. (Hoornik en Den Brabander ademen de eigen tijd nog wel, aldus Rodenko, maar alleen naar inhoud; ze zijn niet 'modern', evenmin als Vasalis, Nijhoff, Bloem en Roland Holst, die je nu met een zekere 'historische instelling' leest.) 17 
Een nieuwe tijd is er nog niet, schrijft Rodenko, maar er valt toch al iets te bespeuren bij Andreus, Polet, Claus en bij hemzelf. Nieuw is onder andere een bij Van Ostaijen aanknopend neo-expressionisme. Misschien dragen Diels en Tergast tot vernieuwing bij, en experimentelen als Lucebert en Kouwenaar. 'Het begint onder de jongere dichters langzamerhand te gisten, men voelt dat de traditionele verzenmakerij niet meer bevredigt, men zoekt nieuwe wegen, nieuwe vormen' (p.370). Deze dichters moeten echter voor een groter forum spreken en elkaars werk gaan lezen, vindt Rodenko. (Na deze inleiding bespreekt hij De Windroos-bundels van Van der Molen en Verhoeven zonder erg enthousiast te worden.)

Rodenko zal zich in de volgende jaargangen in Podium niet meer over poëzie uitlaten, maar het bovengenoemde stuk blijkt op een cruciaal ogenblik te zijn verschenen. Want vanaf de zevende jaargang (195 I) lijkt het pleit beslist ten faveure van die jongere dichters, waartoe Rodenko kennelijk ook zichzelf rekent. Hans Ândreus treedt nu tot de redactie van Podium toe en verzorgt het eerste nummer, dat opent met het beroemde programmatische 'School der Poëzie' van Lucebert: ${ }^{18}$

$i k$ ben geen lieflijke dichter,

ik ben de schielijke oplichter

der liefde, zie onder haar de haat

en daarop een kaaklende daad.

lyriek is de moeder der politiek

$i k$ ben niets dan omroeper van oproer

en mijn mystiek is het bedorven voer

van leugen waarmee de deugd zich uitziekt.

ik bericht, dat de dichters van fluweel

schuw en humanisties dood gaan.

voortaan zal de hete ijzeren keel

der ontroerde beulen muzikaal opengaan.

nog $i k$, die in deze bundel woon 
als een rat in de val, snak naar bet riool

van revolutie en roep: rijmratten, hoon,

hoon nog deze veel te schone poezieschool.

We zien dat Lucebert zich in dit vers, evenals Sierksma in het eerder aangehaalde gedicht, afzet tegen halfzachte lyriek, tegen stemmige liefdespoëzie en tegen estheticisme. Maar hoe geladen, energiek, persoonlijk en extreem is deze poëzie niet vergeleken met 'Bye-bye to those poets', waarin Sierksma bijvoorbeeld de liefdeslyriek halfwassen parodieert ('een zachte helling in de Venusbergen / glooit naar de Droom'). Lucebert ontluistert; hij licht die liefde op (letterlijk en figuurlijk) en ziet onder haar de haat en daarop (temporeel en aanduiding van plaats) een 'kaaklende daad' (dus als gevolg van het liefhebben wordt gekakeld, en liefdeslyriek is wellicht gekakel, omdat het op de haat onder de liefde gestapeld ligt). We zien dat dit gedicht extremer is dan dat van Sierksma, en tegelijkertijd veel dubbelzinniger en daardoor rijker. En het wijst niet alleen een bepaalde lyriek af, het laat ook binnen het gedicht zien hoe het wel kan: 'voortaan zal de hete ijzeren keel / der ontroerde beulen muzikaal opengaan'. Daarnaast toont het gedicht hoezeer het tijd is voor een revolutie: de dichter is 'niets dan omroeper van oproer', hij snakt 'naar het riool van revolutie'.

Een verdere interpretatie van dit gedicht is hier niet aan de orde; het gaat erom dat binnen enkele jaren kennelijk veel veranderd is. 'Twee gedichten 'beweren' nog globaal hetzelfde en oppervlakkig bezien heeft ook de vorm van beide (vierregelige strofen met eindrijm) nog veel van elkaar weg, maar ze verschillen toch zodanig dat er eerder drie decennia dan krap drie jaar tussen lijken te liggen. Luceberts vers verdisconteert niet alleen de strekking van Sierksma's 'Bye-bye to those poets', maar voegt aan kritiek en spot ook zelfkritiek en zelfspot toe (regel $2 / 3$ en laatste strofe). Door de vele paradoxen en opzettelijke dubbelzinnigheden gaat het gedicht veel meer een eigen leven leiden, het is niet meer louter een voertuig gestuurd door een boodschap. De taal wint aan autonomie.

Een in het oog springend onderscheid tussen de twee gedich- 
ten is overigens dat 'School der Poëzie' een 'antimorele' strekking heeft; de dichter is oplichter en ziekt de deugd uit met leugens. De humanist met haar op zijn tanden is hier een revolutionair geworden. Of, in de terminologie van die tijd: de nieuwe poëzie is ahumanistisch, hoewel niet antihumanistisch. $19 \mathrm{Het}$ is overigens dit antimorele, niet-humanistische karakter dat de belangrijkste inhoudelijke overeenkomst vormt met de vernieuwing van de literaire roman in deze jaren door de eerder genoemde (en ook in Podium figurerende) 'landerigen' als Hermans en Van het Reve. ${ }^{20}$

Het karakter van Podium wijzigt zich snel. De taaie, inmiddels gedateerd lijkende essayistiek van Sierksma maakt plaats voor het soort proza en poëzie dat na de oorlog nog lang furore zou maken. Zoals Rodenko het destijds uitdrukte, ontwikkelde Podium zich 'van voornamelijk essayistisch tijdschrift, waarin de discussies over de "new god" een grote plaats innamen, tot tijdschrift van de experimentele avantgarde, van theoretiserend-óver tot experimenterend-mét tijdschrift'. ${ }^{21}$

De literaire en maatschappelijke normen van Forum hebben dan ook langzamerhand, zeker voor de poëzie, in Podium afgedaan. In die zin zijn Sierksma en Rodenko de douanebeambten van twee tijdperken: van Sierksma naar Rodenko is van Forum naar Vijftig.

\section{De jongens op bet podium}

Vanaf de zevende jaargang publiceert Podium een tijdlang hoofdzakelijk poëzie van de Vijftigers. Men kan erover twisten of de verandering van Podium tot 'het tijdschrift van de avantgarde' (Borgers, p. 12 ) geleidelijk plaatsvond of in één klap, maar als we het beeld scherp stellen op de poëzie, is het laatste goed te verdedigen, alleen al door te letten op welke gedichten er plotseling (niet meer) geplaatst worden.

Met ingang van deze jaargang ( I 95 I) komt er ook meer onrust en heibel in en rond Podium. Allereerst pleit Rodenko voor een koerswijziging waarin meer plaats wordt ingeruimd voor psy- 
chologie, antropologie en fenomenologische cultuurkritiek. ${ }^{22}$ De redactie voelt hier weinig voor, waarna Rodenko en Hermans zich terugtrekken. In de zomer stappen ook de andere redacteuren (Hans Andreus, Louis-Paul Boon, Gaston Burssens, W.H. Nagel, D. Opsomer, de weer toegetreden Fokke Sierksma, S. Vestdijk en Hans van Straten) op, waarna G. Borgers enig redacteur wordt, onder andere 'omdat hij met een zuiver gevoel voor het experiment behept is'. De anderen blijven wel als medewerker aan Podium verbonden. (vII:24I)

In $195 \mathrm{I}$ vindt een van de geruchtmakende opstootjes in het Stedelijk Museum van Amsterdam plaats. Bij de opening van een tentoonstelling van de Experimentele Groep in november I 949 was het daar al eens tot een handgemeen gekomen, waarbij onder anderen Lucebert betrokken was. Op I maart 195 I organiseert Podium in samenwerking met de Bezige Bij een literaire avond in het Stedelijk Museum naar aanleiding van de boekenweek. 'Hoogtepunt en toppunt van de avond,' zo meldt $\mathrm{Het} \mathrm{Pa}$ rool meesmuilend, 'was weer eens de "experimentele" dichter Lucebert, die opnieuw kans gezien had het Stedelijk Museum binnen te glippen en zijn stem in onrijm te verheffen.' De letterkunde-redacteur van deze krant was not amused bij het dadaïstisch geïnspireerde optreden van de dichter, wiens gedicht 'Herfst' bestond uit het omkeren van een glas water boven het eigen hoofd. 'Hierdoor niet ontnuchterd,' schrijft de journalist, 'stak hij enig koud vuurwerk af en weerlegde een mogelijke verdenking van analphabetisme door het gevoelvol voordragen van het abc.'

De sfeer van deze avond in een bomvolle aula maakt achteraf een vertrouwd hilarisch-provocerende indruk. (G. Borgers kondigde een stuk van Max Croiset aan, dat deze 'geheel zelf bedacht' had.) De verontwaardigde toon van Het Parool doet nu, na Provo en de jaren zeventig, opvallend ouderwets aan. ${ }^{23}$

In 195 I begint ook de rel rond een voorgepubliceerd fragment van W.F. Hermans uit $I k$ heb altijd gelijk, waarin een voor rooms-katholieken als beledigend opgevatte passage voorkomt. Hermans laat de hoofdpersoon uit deze roman uitroepen: 


\section{Steeds mooier}

De katbolieken! Dat is bet meest schunnige, belazerde, onderkruiperige, besodemieterde deel van ons volk! Maar die naaien er op los! Die planten zich voort! Als konijnen, ratten, vlooien, luizen. Die emigreren niet! Die blijven wel zitten in Brabant en Limburg met puisten op hun wangen en rotte kiezen van het ouwels vreten! (vII: 202-203)

Dit kon niet in de jaren vijftig. Hermans werd - op instigatie van de Volkskrant (katholiek) en De Telegraaf aangeklaagd (en in maart I952 vrijgesproken). Hangende het proces tegen Hermans staakte staatssecretaris Cals de subsidie aan Podium, zodat het tijdschrift de achtste jaargang opende met een nooduitgave in een vrijwel gelijk formaat [...] als tijdens onze illegale tijd onder de Duitse bezetting'. (VII: I-6)

In dit nummer bespreekt Hans van Straten de eerste bloemlezing waarin de Vijftigers zich gezamenlijk aan een groot publiek presenteren, de door Vinkenoog geredigeerde bundel Atonaal. ${ }^{24}$ De recensie is badinerend van toon, Atonaal is een "niet onplezierig boekje', alleen niet de bloemlezing uit de experimentele poëzie. De inleiding van Simon Vinkenoog vindt Van Straten weinigzeggend, een kritiek die hij later in dezelfde jaargang zal herhalen naar aanleiding van een stuk van Vinkenoog in Tijd en Mens. Hierin veroordeelt hij (niet geheel ten onrechte) de gemeenplaatsen van Vinkenoog en bovendien diens geringschatting van de traditie van Marsman, Van Ostaijen en Achterberg, een kritiek die in het verlengde ligt van wat eerder als de tendens-Sierksma is omschreven. ${ }^{25}$

Podium gaat in de loop van 952 een (slechts korte tijd standhoudende) fusie met Tijd en Mens aan. De redactie kondigt aan voortaan meer uitsluitend het blad der niet-traditionele jongeren (te) zijn'. (vII:209) Na allerlei perikelen met uitgevers verschijnt het pas na een half jaar weer met een negende jaargang (oktober 1953).

In het eerste nummer recenseert Van Straten Den Bestens bloemlezing Stroomgebied onder de dat jaar niet van actualiteit gespeende titel 'Een overstromingsramp'. (Ix:\$7-60) Hij klaagt erover dat Den Besten geen duidelijke keus heeft gemaakt door 
'zowel de epigonenkool [...] als de experimentele geit (te) willen sparen'. Hij had zich beter 'kunnen bezighouden met de vraag, waarom de poëzie van I945 moest doodlopen, en hoe de omwenteling zich voltrok'. Van Straten lijkt hier het standpunt van het 'avantgardistische' Podium te vertolken, maar dat een impliciete groepsideologie hem tegen de borst stuit, blijkt later in dat jaar, als het merendeel van de medewerkers besluit voortaan uitsluitend aan Podium mee te werken en hun tijdschrift geheel als een blad van de avant-garde te beschouwen. Dan verlaat hij $P_{0}$ dium.

Uit de 'bij wijze van inleiding' gepubliceerde brief van Van Straten aan Gerrit Borgers, die eindigt met het reeds geciteerde bezwaar over de 'massale onpersoonlijkheid' van de Vijftigers, spreekt teleurstelling, zowel over de aard van de revolutie als over het gebrek aan (zelf)kritiek. Deze bezwaren worden nog eens uit de doeken gedaan in een reactie op de stevige repliek van Kouwenaar. ${ }^{26}$ Van Straten vindt dat de experimentelen 'zich wat àl te volgzaam in het slootje van de officiële literatuur hebben laten binnenloodsen' en zich nu niet verder meer ontwikkelen. De beweging is conservatief geworden, zoals elke revolutie verburgerlijkt. Verder laten de Vijftigers na, 'méér te zijn dan een zuiver poëtische vernieuwing'. Hij denkt daarbij aan een meeromvattende mentaliteitsverandering en aan andere kunstvormen als ballet, toneel en film. Men is echter gearriveerd en discussie is niet langer welkom, terwijl het de vraag is of de revolutie eigenlijk wel geslaagd is. Publiceren de dichters van vroeger niet op even grote schaal door?

Kouwenaars antwoord aan Van Straten illustreert wel enigszins dat kritiek op de beweging gevoelig ligt: hij noemt Van Straten een 'rancuneus mannetje' met een 'zure, verbitterde, betweterige oude-mannentoon' zonder echt revolutionair verleden. Met het vertrek van Van Straten verdwijnt deze discussie over het hoeden van de revolutie echter snel onder de oppervlakte.

In de negende jaargang toonde Podium zijn provocerende houding opnieuw door vier pagina's met foto's af te drukken van weer een roemruchte rel in het Stedelijk Museum, alsmede 
een collage van kranteknipsels die hiervan verslag deden. Bij deze (weer goed in de avant-gardetraditie passende) heibel ging het om de uitreiking aan Lucebert van de Poëzieprijs van de gemeente Amsterdam. De dichter, als keizer verkleed en vergezeld van een hofhouding, werd bij deze gelegenheid de toegang door de politie ontzegd. ${ }^{27}$

De tiende jaargang, die de redactie in januari 1955 laat beginnen, besteedt naast het genoemde stuk van Van Straten en experimentele gedichten nauwelijks aandacht aan de nieuwe poëzie. We vinden alleen een vinnig stukje van Lucebert over Bertus Aafjes, die met zijn vrouw Poes in de Libelle staat afgebeeld (een laatste knalletje na de heftige schotenwisseling tussen Aafjes en Lucebert in de jaren daarvoor) en een bespreking door L.Th. Lehmann van de door Kouwenaar geredigeerde bloemlezing Viff s tigers, die begin 1955 was verschenen. ${ }^{28}$ Lehmann wijdt lovende woorden aan de opgenomen dichters Campert, Elburg, Kouwenaar en Lucebert. Alleen Schierbeek bevalt hem niet: 'Ik word schier bekaf van Schierbeek.'

\section{Erwas geen terug meer}

In r95s is Podium niet meer een eiland van erkenning in een zee van onbegrip, conservatisme of verzet jegens de nieuwe poëzie: de Beweging van Vijftig is inderdaad - in de woorden van Van Straten - de officiële literatuur binnengeloodst. De Vijftigers publiceren in een aantal literaire tijdschriften (naast Podium onder andere in Maatstaf, Libertinage en De Gids). Kranten en tijdschriften (waaronder de Nieuwe Rotterdamsche Courant, Het Parool, De Groene Amsterdammer en Vrij Nederland) schrijven niet alleen geregeld over hen, maar bieden hun ook ruimte tot polemiek en publieke standpuntbepalingen.

Na een marginale erkenning tot aan 195 I, een cruciaal tijdstip (slechts Vinkenoog had tot dan een bundel 'nieuwe' poëzie gepubliceerd), debuteren in datzelfde jaar Rodenko, Andreus, Campert en Hanlo in De Windroos-serie van Den Besten, terwijl de bloemlezing Atonaal en het debuut van Lucebert bij 
Stols verschijnen. Verder wordt aan Elburg in 1951 een reistoelage toegekend en krijgt Schierbeek - van wie in dit jaar Het boek ik verschijnt - een regeringsopdracht tot het schrijven van een novelle.

De in r950 overleden Hans Lodeizen ontvangt postuum de Jan Campertprijs I95 I. In de paar hierop volgende jaren wisselen prijzen en rellen, beide met de daarbij horende publiciteit, elkaar af. Zo wordt in 1952 in de Eerste Kamer de subsidiëring van het tijdschrift Roeping aangevochten vanwege Hanlo's gedicht 'Oote' ('Oote oote oote / Boe / Oote oote / Oote oote oote boe / Oe oe' enzovoort), terwijl anderzijds Andreus een regeringsopdracht voor een gedichtencyclus krijgt en Rodenko voor de Jan Campertstichting een essay over Lodeizen mag schrijven. In 1953 prijzen voor Lucebert (Poëzieprijs van de gemeente Amsterdam) en Campert (Reina Prinsen Geerligsprijs) en debuten van onder anderen Polet (in De Windroos-serie) en Kousbroek (bij Stols), waarna begin 1954 de hierboven reeds genoemde bekroning van 'De Keizer der Vijftigers' plaatsgrijpt.

De 'doorbraak' in het eerste Podium-nummer van 1951 is dus niet een exclusieve, geïsoleerde verschuiving, maar eerder op te vatten als het beginpunt van een zich al snel uitbreidende vernieuwing. De vraag is nu in welk opzicht de tijdgenoten deze vernieuwing toen als vooruitgang opvatten en waaruit deze vooruitgang of vernieuwing volgens hen dan bestond.

In 1955 schreef Gerrit Kouwenaar in Vrij Nederland: 'De experimentele poëzie is de enige levende poëzie, die momenteel existeert [...]. De rest is mooi dood of lelijk dood [...] maar dood, geschiedenis'. (26-3-1955) En in zijn inleiding op Vijfs tigers, dat kort daarvoor verschenen was, blikte hij als volgt op de voorafgaande jaren terug: 'Hoezeer verklaarbaar ook achteraf, het blijft merkwaardig hoe een jaar of wat na de bevrijding eensklaps van alle kanten jonge dichters opdoken, veelal onafhankelijk van elkaar op weg gingen en zich aan die brede delta troffen alvorens samen in zee te steken, of juister: te worden gedreven, want er was geen terug meer.'29

Met andere woorden, de traditionele poëzie heeft afgedaan en is voorbij, geschiedenis; de nieuwe, experimentele poëzie is 
door de noodzaak van historische ontwikkelingen onstuitbaar gebleken; er was geen terug meer. Een dergelijk gevoel leefde sterk onder de protagonisten van Vijftig, het gevoel de geschiedenis aan hun kant te hebben, deel uit te maken van een historisch proces dat (voor zover het poëzie betreft) een verbetering impliceert. Het opsporen van dergelijke vooronderstellingen in het eerste decennium van Podium blijkt echter een geschakeerd beeld op te leveren.

Allereerst dient onderscheid te worden gemaakt tussen een historiserend en een niet-historiserend perspectief. Zo werden de eerste jaren na de oorlog opgevat als een impasse, een historiserende metafoor, maar eveneens als een vacuüm, een statische metafoor. Podium verzette zich in die jaren tegen estheticisme, gevoelslyriek en poëzie van de ivoren toren en stelde een 'windstilte' vast. De kritiek is duidelijk genoeg, maar wordt niet steeds in het kader van al dan niet noodzakelijk geachte historische ontwikkelingen bezien.

Toch horen we vanaf de tweede jaargang ook dat historiserende geluid, waarbij het besef van een impasse naar voren komt: waar de redactie, zoals eerder geciteerd, de poëzie verschraald acht 'tot een armetierige lyriek - een impasse'. Of waar Rodenko beweert dat de jongeren eerder in een impasse verkeren dan dat er van onmacht sprake is, daarmee een historische categorie verkiezend boven een psychologische categorie.

Bij de tendens-Sierksma wordt de mogelijkheid van vooruitgang of vernieuwing niet geloochend en er blijkt zelfs sympathie met enig revolutionair elan, dat echter door grote scepsis wordt beteugeld, getuige Sierksma's bespreking van Reflex. Het heden heeft afgedaan, vernieuwing zal echter moeten plaatsvinden door oriëntatie op de Nederlandse traditie. Weliswaar beweert Sierksma dat onze poëzie achterloopt bij onder andere de Franse, maar zijn conclusie is geenszins dat we daarbij aan moeten sluiten. (v:26) Bij de tendens-Rodenko heeft het heden ook afgedaan, maar daar wordt de ernstiger ingeschatte 'achterstand op het buitenland' door een grotere oriëntatie op internationale stromingen gecompenseerd. Maar niet exclusief, want het verwijt het buitenland van na de Eerste Wereldoorlog slechts na te 
apen zit de Vijftigers niet lekker.

De constructie van de eigen voorgeschiedenis vereist een bredere aanpak, waarin niet alleen de revolutionaire breuk moet worden beklemtoond; de voor een vooruitgangsperspectief vereiste continuïteit heeft eveneens een traditie van node, die ook in het eigen taalgebied verankerd ligt. Met andere woorden: de geschiedenis dient te worden herschreven, zoals in het vorige hoofdstuk werd aangegeven. In dit licht stelt Paul Rodenko in I 954 een bloemlezing samen uit de Nederlandse poëzie, waarin hij wil laten zien dat de avant-garde een al lang in buiten- en binnenland bestaande ontwikkeling is. Daartoe neemt hij bijvoorbeeld ook werk van Guido Gezelle, Herman Gorter en J.H. Leopold op. $3^{\circ}$

Met deze bloemlezing voorziet Rodenko de 'doorbraak naar een nieuwe poëtische orde' van een voorgeschiedenis die het beter mogelijk maakt de veranderingen als vooruitgang op te vatten dan wanneer de breuk met het verleden al te zeer beklemtoond wordt. Kouwenaar zoekt (of: construeert) de voorgeschiedenis van de beweging daarentegen exclusiever in het buitenland. In zijn inleiding op Vijf s tigers beschrijft hij een scherpe breuk in de Nederlandse poëzie. Maar tegelijkertijd onderstreept hij het belang van de buitenlandse traditie; in feite een uiting van Kosellecks gelijktijdige van het ongelijktijdige, waarin achterstand en voorsprong kunnen worden verkondigd zodat een appel tot verandering doorklinkt. ${ }^{31}$

Vanaf de zesde jaargang van Podium, wanneer zich de contouren van een nieuwe, andere poëzie beginnen af te tekenen, beschouwen de medewerkers deze ontwikkeling als een wenselijke, en soms ook als een noodzakelijke vernieuwing, als een vorm van vooruitgang dus. In de vijfde jaargang had Sierksma zich nog afgezet tegen de poëzie van Elburg en Lucebert in $R e-$ flex, maar daarna waait er een andere wind, getuige het reeds genoemde artikel van Rodenko in zijn Poëziekroniek, dat vanuit een herkenbaar vooruitgangsperspectief geschreven is. De poëzie van jongeren kan immers de culturele impasse doorbreken, een tijdperk (van Verzamelde Werken) is afgesloten en een aantal dichters dat de eigen tijd aanvoelt is toch niet 'modern' 
vanwege de vorm. Rodenko presenteert het soms nog bescheiden, maar onmiskenbaar: er begint een nieuwe tijd voor de poëzie, een geleidelijke, wenselijke verbetering. Men is, zo schrijft hij, 'waarheen dan ook, weer op weg'. (vI:37I)

Vinkenoog beschrijft in de achtste jaargang de verandering als vernieuwingen die het vers uit zijn esthetisch isolement halen, maar hij heeft nauwelijks een historisch perspectief. Hij worstelt eerder met het gebrek aan erkenning: waarom wordt de traditionelere Van Tienhoven zo overschat? Zie de angst voor het nieuwe bij de kritiek, getuige het negeren van Luceberts 'Triangel in de jungle' en de manier waarop Elseviers Weekblad Hanlo's 'Oote' onder commentaar bedelft! (VIII: 135 - I38)

Het is opvallend dat ook Hans van Straten, die wat zijn scepsis betreft in het verlengde van de tendens-Sierksma staat, in zijn kritiek op de Beweging van Vijftig het gezichtspunt van vooruitgang niet verlaat. Nu zit er in zijn uitlatingen nogal wat polemische ruis en het is niet ondenkbaar dat een dergelijk standpunt evengoed een retorisch bastion is, als dat het van een werkelijk geloof in de toenmalige vernieuwingen getuigt. Dit laat zijn sympathie met revolutionaire verandering in het algemeen echter toch grotendeels onverlet. Van Straten spreekt van een wenselijke en noodzakelijke artistieke explosie. ${ }^{32} \mathrm{Hij}$ betreurt het juist dat de revolutie verburgerlijkt en dat de beweging conservatief wordt. De Vijftigers hebben zich in laten kapselen terwijl de oude dichters niet zijn opgeruimd, en bovendien hebben ze zich slechts tot 'poëtische vernieuwing' beperkt.

Dergelijke uitlatingen passen naadloos in het avantgardistisch taalgebruik van veel vernieuwingsbewegingen. Opmerkelijk is wel, dat Van Straten zich over de inhoud van die poëtische vernieuwing niet uitlaat en dat het hem eerder om een bepaalde mentaliteit lijkt te gaan, een benadering die sterk aan die van Sierksma doet denken.

Waaruit bestond deze poëtische vernieuwing dan volgens de Vijftigers? Wie in Podium (tot en met 1955) meent daarop een antwoord te vinden, wordt teleurgesteld. Het gemis aan kritiek, we kwamen het al eerder tegen, werd reeds in die tijd herhaaldelijk opgemerkt. Een groot deel van de vernieuwing is gedurende 
het eerste decennium van Podium slechts ex negativo gekarakteriseerd, als verzet tegen een al te overheersend soort poëzie. Als gezegd gaat het hier om de veroordeling van estheticisme, subjectieve lyriek, om een (blijkens Luceberts 'School der Poèzie') antimoralistische gezindheid en om afkeer van klassieke vormprincipes in de poëzie, vooral het sonnet.

Wat de vernieuwing in positieve zin inhield, wordt in Podium nauwelijks beschreven. Rodenko wijst zijdelings op een heroriëntatie op het 'neo-expressionisme' van Van Ostaijen en op 'plastische verbeeldingskracht'. In de poëzie zelf doemt echter herhaaldelijk iets van een programma op; Lucebert propageert oproer en laat 'de hete ijzeren keel / der ontroerde beulen muzikaal opengaan', Campert lanceert een nieuw vitalisme, dat karakteristiek wordt voor veel gedichten van Vijftig:

Poëzie is een daad

van bevestiging. I $\mathrm{k}$ bevestig

dat ik leef, dat ik niet alleen leef.

$[\cdots]$

Poëzie is mijn adem, beweegt

mijn voeten, aarzelend soms,

over de aarde die daarom vraagt.

$[\ldots] 33$

Daarbuiten beperken programmatische verklaringen zich echter enkel tot losse bijvoeglijke naamwoorden als 'experimenteel', 'nieuw' of 'modern'. Willen we ons bij Podium houden, dan zouden we hoogstens nog het door Sierksma met enige sceptische instemming samengevatte programma van Reflex kunnen aanhalen; ten slotte waren Elburg, Kouwenaar en Lucebert in die tijd aan de Experimentele Groep verbonden. De opvattingen die Sierksma noemt, zijn weer grotendeels negatief: tegen 'formalisme dat abstractie boven levende uitdrukking stelt'; en tegen het onderscheid cussen vorm en inhoud waar- 
door estheticisme ontstaat, dat ook nog eens de kloof tussen volk en kunstenaar vergroot. Positief geformuleerd is alleen de opvatting 'dat de artistieke uitdrukkingen van de kinderen en de volkskunst [...] van groot belang zijn'.34

Waaruit de poëtische vernieuwingen bestonden, wordt buiten Podium (voor 1956) echter wel degelijk beschreven. Allereerst onderkent men een herwaardering van het irrationele, die gedeeltelijk geënt is op het surrealisme, maar ook op primitivistische invloeden, en die eveneens samenhangt met noties als spontaniteit, het onbewuste, volkskunst en uitdrukkingen van kinderen.

Verder worden de veranderingen in vorm steeds beklemtoond en gedeeltelijk in samenhang hiermee de toenemende autonomie van het gedicht - achteraf bezien misschien nog wel de meest ingrijpende vernieuwing. Daarnaast worden ook een zeker maatschappelijk engagement genoemd (dat echter slechts voor enkelen opgaat, bijvoorbeeld voor Elburg, die dichters ziet optreden als wegbereiders naar een nieuwe samenleving, gedreven als zij zijn door 'de drang naar progressie'35), meer aandacht voor lichamelijkheid en zintuiglijkheid, alsmede de verwoording van een nieuw, 'modern' levensgevoel, vaak uitgedrukt met Luceberts karakteristiek van 'de ruimte van het volledig leven'. Ten slotte wordt gewezen op de cognitieve vernieuwing in de poëzie van Vijftig, die met de toenemende autonomie ervan samenhangt; het is, zo zegt Kouwenaar, 'eerder de bedoeling van het gedicht, waarom het gaat, dan de bedoeling van de dichter, die immers niet iets uitbeeldt, dat hij voorradig had, maar iets ervaart dat hij nog niet kende'. ${ }^{36}$

\section{Eerst alle oude pikken uitroeien}

Keren we terug naar de 'komplottheorie' van Vijftig, die een zekere strategie of ten minste een gemeenschappelijke houding tegenover de buitenwacht suggereert. In hoeverre, zo vroeg ik me af, volgt zo'n vernieuwingsbeweging een bepaalde al dan niet bewuste tactiek om erkenning te krijgen? En om te beginnen, 
wordt er in zo'n veronderstelde strategie van vooruitgangsbegrippen gebruik gemaakt?

De laatste vraag is al ten dele beantwoord. Hoewel het commentaar van de eerste tien jaargangen Podium beperkt was, kon worden vastgesteld dat protagonisten van de Beweging van Vijftig de ontwikkelingen inderdaad als een vorm van vooruitgang beoordeelden, al wordt dit pas echt duidelijk uit andere teksten. Op het moment dat deze ontwikkelingen in een vooruitgangsperspectief worden bezien, is dat niet meer alleen een constatering, maar ook een stellingname; niet meer alleen descriptief maar ook normatief. In welke mate het appel van zo'n perspectief werkt, valt aan het beperkte materiaal van Podium echter nauwelijks af te lezen. We maken er iets uit op bij de discussie tussen Van Straten en Kouwenaar.

'Laat mij dan maar Trotzkist zijn,' had de eerste geschreven toen hij de beweging van conservatisme betichtte, waarop Kouwenaar antwoordde dat Van Straten er nooit bij had gehoord, hoezeer hij ook sinds 195 I zonder hoofdletters en leestekens schreef; hij ontbeerde nu eenmaal een revolutionair verleden. (IX: I 95, 3 I 8 e.v.) Dit illustreert een zeker 'vooruitgangsbewustzijn', maar tegelijkertijd ook iets van zo'n gemeenschappelijke houding, die enkele keren eerder al in Podium naar voren was gekomen en die karakteristiek is voor veel avant-gardebewegingen in de kunst. Weliswaar beweert Kouwenaar in zijn inleiding op Viff s tigers dat de experimentele poëzie geen gemeenschappelijk programma heeft, dat 'de zogezegde experimentelen geen school, geen vakvereniging, geen partij vormen' en dat vooral 'de situatie' hen bij elkaar heeft gebracht, maar een zeker gesloten groepsoptreden is bij de Vijftigers toch evident. 37

Een uiting daarvan is de reeds genoemde Podium-avond in I95 I in het Stedelijk Museum en de enkele jaren later ook daar plaatsvindende rel, waarvan Podium foto's afdrukte. Daaruit blijkt dat de Vijftigers als groep de publiciteit zochten, wat vanzelfsprekend ook duidelijk wordt door hun bloemlezingen Vijf 5 tigers en vooral Atonaal. Uit de latere jaargangen van $\mathrm{Po}$ dium's eerste decennium komt zo'n groepsverband ook naar voren. Zo zagen we Vinkenoog reeds klagen over de aan ande- 
ren toegezwaaide lof en de gebrekkige aandacht voor Andreus en Lucebert, over het doodzwijgen bijvoorbeeld van 'Triangel in de jungle' van de laatste, en over de manier waarop Elseviers Weekblad het destijds aanstootgevende gedicht 'Oote' met een enquête te lijf gaat. Ook viel te beluisteren hoe de redactie in datzelfde jaar aankondigde 'meer uitsluitend het blad der niettraditionele jongeren te zijn', een aanduiding die doet vermoeden dat de rijen gesloten worden. (vm:209)

Dat dit inderdaad gebeurt, hoeft nog niet per se te blijken uit de manier waarop Kouwenaar 'de' Vijftigers verdedigt tegen kritiek die het Amsterdams Tijdschrift voor Letterkunde op de nieuwe poëzie heeft, maar het wordt wel duidelijk wanneer Van Straten opstapt. Een aanleiding, zo niet een reden, lijkt de afspraak van het merendeel van de Podium-medewerkers (onder wie nu ook Campert en Elburg), om voortaan uitsluitend aan dit blad mee te werken. Als Van Straten daar niet aan meedoet en als outsider kritiek levert, volgt een reactie van Kouwenaar die achteraf wel erg heftig lijkt. Uit zo'n excommunicatie spreekt de houding van wie niet voor ons is, is tegen ons, al zullen ongetwijfeld ook persoonlijke verhoudingen een rol hebben gespeeld.

De onderlinge sfeer of sociale coherentie blijkt ook uit commentaar van Bert Schierbeek, die over de tijd van Braak het volgende schreef: 'We hebben met een enorm plezier die nummers in elkaar gezet. De bedrijvigheid was groot. Iedereen was bezig en inspireerde iedereen [...] Het was een mooie tijd, een verwarde tijd ook wat de menselijke verhoudingen betrof, en de spiritualiën vloeiden overvloedig. De onderlinge beïnvloeding bestond natuurlijk ook wel, maar die was toch niet erg groot, daarvoor was ieder van ons te zeer bezig met zichzelf. Alleen naar buiten trokken we hetzelfde gezicht.' 38

De roep om vernieuwing, zo is inmiddels gebleken, was niet louter retorisch in de zin van Vestdijk, het was ook een belangrijk wapen voor een gezamenlijke strategie. In Fokkema's Het komplot der Vijftigers staan legio voorbeelden van een dergelijke avantgardistische groepsgeest. De Vijftigers worden, zo schrijft hij, in de eerste plaats bijeengehouden door het idee 
“een poëtische opleving" te vertegenwoordigen en een nieuwe generatie te vormen'. En al ontkennen ze regelmatig een groep te vormen, ze houden 'aanvankelijk terwille van het groepsbelang in literair-politieke zin onderlinge controversen zoveel mogelijk binnenskamers". 39 Zolang er een vijandige buitenwacht is, is er een groep. Op het moment dat die groep als voorhoede van de avant-garde ( $h$ )erkend wordt, begint hij uit elkaar te vallen en krijgen onderlinge tegenstellingen meer aandacht. Maar eerst moet acceptatie volgen. Dat blijkt bijvoorbeeld uit een brief van Campert, die in 1950 aan Vinkenoog schrijft niet zo enthousiast te zijn over de gedichten van Kousbroek, al mag Vinkenoog hem dat niet doorvertellen. 'Enfin over vijf jaar weten we meer,' vervolgt Campert. 'Eerst alle oude pikken uitroeien. ${ }^{40}$

\section{Literatuurgeschiedenis als vooruitgang}

In hoeverre beoordeelden latere critici en literatuurhistorici de hierboven geschetste veranderingen nu als vooruitgang en in welke mate verschilde dat perspectief van dat van de direct betrokkenen van destijds? De opvatting dat de Beweging van Vijftig een opleving in de Nederlandse literatuur is geweest, werd en wordt nog altijd algemeen gedeeld, al zijn er de laatste decennia herhaaldelijk mislukte aanslagen gepleegd op de hegemonie die de Vijftigers in althans de poëziegeschiedenis lijken te hebben. Hun relatief hoge plaats in de canon verschuift maar zeer geleidelijk, wat voor een deel te danken is aan het feit dat enkele dichters (Kouwenaar, Campert) nog altijd werk van hoog niveau publiceren, dat zich met het beste van latere generaties kan meten. (Kouwenaar heeft zelfs aanwijsbaar een hele generatie beinvloed.)

Een omwenteling als die van Vijftig heeft zich sindsdien niet meer voorgedaan, wat overigens niet meteen hoeft te impliceren dat er na 1955 niet meer van vooruitgang gesproken zou kunnen worden. Het lijkt echter verstandig eerst nog eens stil te staan bij de verschillende betekenissen en perspectieven van vooruitgangsbegrippen. 
Om te beginnen is er natuurlijk verschil tussen de dichters zelf, de critici van destijds, de literatuurhistorici (en het overgangsgebied tussen die twee laatsten, van historiserende critici en kritiek leverende historici) en ten slotte degenen die vanuit een of andere kunsttheoretisch perspectief daarop reflecteren (zoals hier gebeurt). Dichters hebben altijd in enige mate een historisch besef van wat ze doen, omdat hun werk hoe dan ook in een of ander traditie staat en aan die traditie een groot deel van zijn betekenis ontleent. Geen enkele dichter werkt geheel zonder de notie dat een nieuw gedicht bestaansrecht heeft in en door zo'n traditie, dat er dus sprake is van cumulatie en dat dat goed is, dat wil zeggen: wenselijk.4' Alleen kan die traditie klein zijn en relatief sterk vervormd.

De criticus kijkt al afstandelijker en maakt een eerste ordening voor wat geschiedenis gaat worden, soms nog zich vereenzelvigend of zelfs samenvallend met de dichter (Kouwenaar bijvoorbeeld in Vijfs tigers), soms onafhankelijker maar wel sympathiserend met vernieuwing (Rodenko, in mindere mate Den Besten), soms zich daartegen verzettend (Aafjes). De literatuurhistoricus is vanzelfsprekend ook partijdig en levert evengoed een persoonlijke bijdrage an de constructie van de geschiedenis, maar hij is door zijn afstand eigenlijk bij uitstek een opportunist. Hij maakt geschiedenis van de winnaars: Rodenko en Kouwenaar krijgen het historische gelijk dat ze meenden te hebben en waarmee Vestdijk, Aafjes en Van Straten terzijde worden geschoven. $4^{2}$

Wat opvalt is dat er zo'n korte tijd tussen de vernieuwing en de acceptatie van die vernieuwing ligt. In I95 I breken de Vijftigers door, in 1955 krijgen ze al het verwijt tot het establishment te behoren. Dit suggereert een intrigerend kenmerk van veel vernieuwingsbewegingen in de kunst: terugkijkend in de geschiedenis blijkt de strijd om acceptatie vaak onmiddellijk, dus in dezelfde tijdspanne te worden beslecht, waarna de historici hoogstens nog enige globale verbanden aan zullen brengen. De beeldvorming van een vernieuwingsbeweging of van een nieuwe generatie wordt kennelijk in het tijdsbestek van die beweging of generatie gevormd.43 Historici hebben in dit licht 
eerder bemoeienis met het relatieve gewicht van dergelijke veranderingen of stromingen dan dat ze nog veel inhoudelijks aan de gebeurtenissen toevoegen. De ordening van de criticus en de programmatische uitlatingen van een vernieuwingsbeweging zijn voor de historische beeldvorming wellicht belangrijker dan zij op het eerste oog lijken te zijn.

Daarbij is de mate waarin die beeldvorming zich in termen van verandering en vernieuwing uit, cruciaal. De meeste geschiedschrijving van literatuur staat namelijk nog steeds in het verlengde van Wellek en Warrens vlak na de oorlog verschenen, en in het vorige hoofdstuk al ter sprake gebrachte Theory of $L i$ terature, dat literatuurgeschiedenis opvat als een reeks normverschuivingen, als een opeenvolging van systemen van literaire conventies.44 Ook een recente literatuurgeschiedenis als Ton Anbeeks Geschiedenis van de Nederlandse literatuur haalt naar voren wat achteraf bezien de conventies en normen heeft veranderd, wat zich dus als vernieuwend heeft gemanifesteerd en wat - evenzeer door latere conventies gekleurd - als zodanig is geaccepteerd. Een zekere vertekening is hierdoor onvermijdelijk, maar zo'n observatie is bij geschiedschrijving een open deur.45

Dat in een dergelijke benadering vooruitgangsnoties een rol gaan spelen, ligt voor de hand. Zo vat ook Anbeek de veranderingen van Vijftig, in navolging van de Vijftigers zelf, als het inhalen van een achterstand op en wijst hij een aantal verworvenheden als vrijheid van interpunctie, beeldspraak en versbouw aan. $4^{6}$

Algemeen gesteld wordt de toekenning van historisch gewicht aan kunstuitingen grotendeels bepaald door periodisering, en periodisering in de kunst van de laatste tweehonderd jaar wordt doorgaans beheerst door vooruitgangsideeën, door noties van ontwikkeling en modernisering. Of in de literatuurgeschiedenis met betrekking tot poëzie echter van een geleidelijke ontwikkeling of van continuïteit kan worden gesproken, blijft zeer de vraag. Zo wordt de recente geschiedenis van de Nederlandse poëzie vaak in hoofdlijnen gekarakteriseerd door drie losse generaties, Tachtig, Twintig (of Tien) en Vijftig. Deze generaties zijn niet zozeer mijlpalen langs een bepaalde welom- 
schreven weg, als wel losse staketsels die slechts verbonden worden door de dunne lijn van de tijd.47

Inhoudelijk bekeken blijft het moeilijk de ontwikkeling van de Nederlandse poëzie lineair en continu te interpreteren, evenals het lastig is te spreken van een toegenomen niveau van de poëzie. Want welke criteria moeten hiervoor worden aangelegd, zijn deze niet juist heel sterk gebonden aan de op een bepaald moment toonaangevende poëzie? Sommige historici, maar ook de meer direct betrokkenen zijn geneigd de poëzie niet als geisoleerd te beschouwen, maar juist als ingebed in de literatuur, de literatuur in de kunst en de kunst in de maatschappij. Het verband tussen maatschappelijke vooruitgang, al dan niet vermeend, en vooruitgang in de kunst wordt door avantgardebewegingen met grote regelmaat gelegd. Bij de Vijftigers valt het op dat de maatschappelijk meest geëngageerde en vooruitstrevende dichters, te weten Elburg, Kouwenaar en Lucebert (alle drie een tijd lid van de progressieve en sociaal geëngageerde Experimentele Groep in Holland) ook het meest in termen van vooruitgang spreken als het gaat over poëzie, dus een avantgardistische ideologie uitdragen. De relatie tussen maatschappelijke processen op macro-niveau en processen op het beperkte terrein van een kunsttak zijn echter buitengewoon problematisch.

Wel is het mogelijk - en aan het slot van dit boek zal daar nog uitvoeriger op worden ingegaan - om van vooruitgang te reppen door te wijzen op de cognitieve waarde van literatuur en met behulp van het argument van de toenemende kwantiteit. Om met het eerste te beginnen, in zoverre kunst ook wordt opgevat als een vorm van kennis, kun je de poëzie van de Vijftigers als een toename van kennis interpreteren. Door een nieuwe metaforiek en een veranderende beeldtaal verwijst deze poëzie op een andere manier naar hetzij de werkelijkheid, hetzij bewustzijnstoestanden (van lezer of dichter), of zij levert - bij een meer autonome poëzie-opvatting - andere coderingen en mogelijkheden voor taal op, en zo een indirecte toename van kennis. De Beweging van Vijftig heeft zelf al herhaaldelijk op dit cognitieve aspect gewezen, meestal in verband met de term 'experimen- 
teel'. Het woord voert de dichter, aldus Kouwenaar, 'al schrijvend naar onbekende en toch op de een of andere manier herkenbare gebieden'; hij heeft het over 'ontdekkingen, veroveringen' en over 'de exploratie van het onderbewuste'. Of, zoals hierboven aangehaald, de dichter ervaart iets 'dat hij nog niet kende'. $4^{8}$ En Rodenko noemt het gedicht een kennisorgaan.49

Het vooruitgangsperspectief kan ook aannemelijk worden gemaakt met het eenvoudige argument dat er domweg een aantal gedichten bij kwam, alsmede nieuwe technieken en procédés. Daar kan natuurlijk tegen worden ingebracht dat ook veel kunstwerken weer uit de geschiedenis verdwijnen en dat meer nog niet beter hoeft te betekenen. Aan het slot van dit boek zal echter worden betoogd dat 'meer' in de kunst niet 'meer van hetzelfde' is, dat een kwantitatieve toename daarom in dit geval ook kwalitatief is en dat wat verdwijnt vooralsnog niet opweegt tegen wat erbij komt.50 Maar met dergelijke speculaties raken we misschien te ver van de empirisch bedoelde aandacht voor Podium af, dat ongetwijfeld ooit, evenals de poëzie van Vijftig, het slachtoffer van een onbegrensde toekomst wordt. 


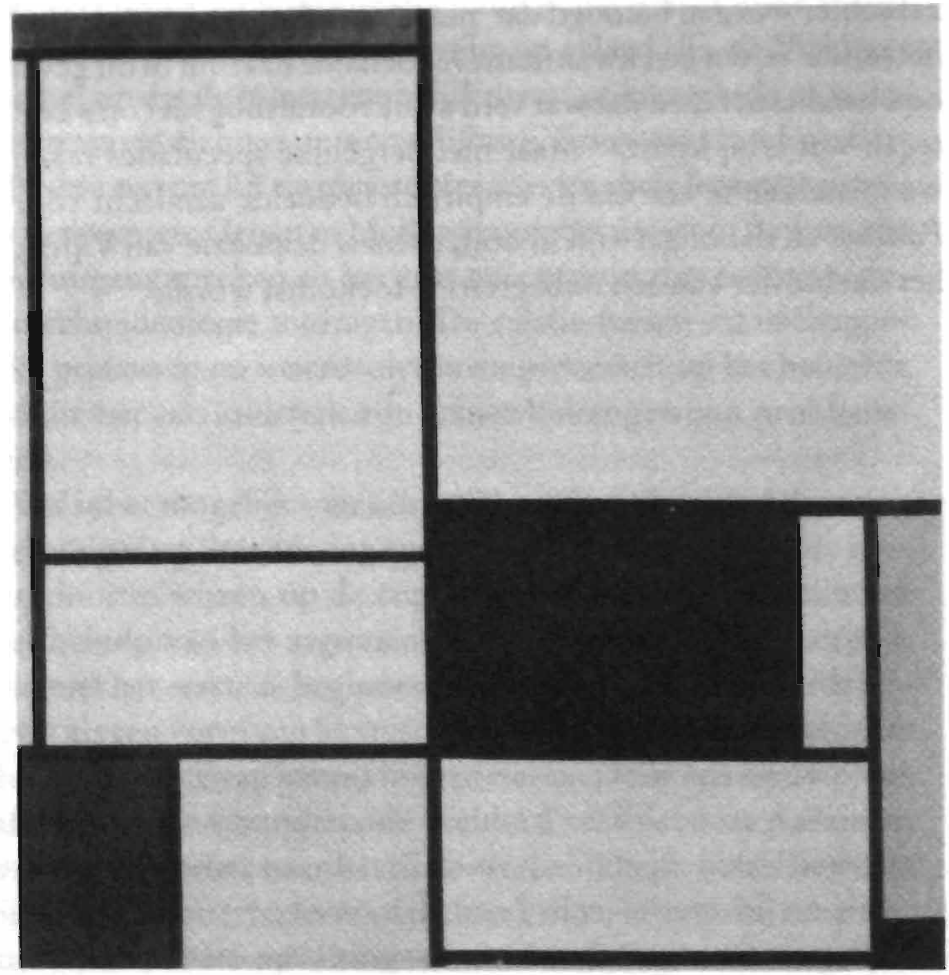

Piet Mondriaan, 'Compositie met Rood, Geel en Blauw' (1921; 103,5 x 99,5 cm) 


\section{Vernieuwing in schilderkunst en architectuur: De Stijl}

Zal, ook in dezen verren toekomst, het volledige leven niet onmogelijk gemaakt worden door de achtergebleven massa?

Het is van geen belang voor de evolutie: deze gaat door en met haar alleen hebben we te rekenen. (Mondriaan, De Stijl v: 44)

Abstractie en de schoonbeid van een graansilo

Toen in 1982 het Amerikaanse Walker Art Center en verschillende musea in Nederland een overzichtstentoonstelling van De Stijl organiseerden, werd vastgesteld dat deze beweging een van de sleutels tot het modernisme was geworden: volgens Friedman bleek De Stijl vijftig jaar na de laatste aflevering van het gelijknamige tijdschrift een

brandpunt van veelomvattende vernieuwingen in schilderkunst, architectuur, toegepaste kunst en grafische vormgeving. ${ }^{1}$

Deze vaststelling heeft iets problematisch, want wie kunsthistorische handboeken opslaat, is geneigd deze constatering als retoriek af te doen. De Stijl staat niet zo centraal als Friedman suggereert, tenzij men het modernisme zo breed interpreteert als door de inflatie van deze term tegenwoordig mogelijk is. Of tenzij men zich beperkt tot het lezen van monografieën over deze beweging of over een van haar protagonisten. Zo karakteriseerde Jaffé De Stijl destijds in navolging van de beweging zelf als signpost, als een baken, als maatstaf voor veranderingen in de zich vervolmakende geschiedenis van de mensheid. ${ }^{2}$

Zo'n waardering van De Stijl, als gids in de kunst of zelfs van het mensdom, lijkt wat overtrokken voor een beweging die 
door een weinig hechte, steeds veranderende groep kunstenaars werd gevormd, een groep die slechts op papier bestond en bijeen werd gehouden door een dun, allengs onregelmatiger verschijnend en hoofdzakelijk in het Nederlands geschreven tijdschriftje met een eenmansredactie. De verspreide oplage van $D e$ Stijl kwam bovendien nooit boven een paar honderd uit en de allereerste woorden van de als beginselverklaring bedoelde inleiding in het eerste nummer luidden terughoudend:

Dit tijdschriftje wil zijn eene bijdrage tot de ontwikkeling van het nieuwe schoonheidsbewustzijn.

Deze bescheiden opmaat werd echter door de redactie, dat wil zeggen door hoofdrolspeler Theo van Doesburg, aldus vervolgd:

Het wil den modernen mensch ontvankelijk maken voor het nieuwe in de Beeldende Kunst. Het wil tegenover de archaïstische verwarring [...] de logische beginselen stellen van een rijpenden stijl, gebaseerd op zuivere verhouding van tijdgeest en uitdrukkingsmiddelen. Het wil de huidige denkrichtingen betreffende de nienwe beelding, die, hoewel in wezen gelijk, zich onafhankelijk van elkaâr ontwikkeld hebben, in zich vereenigen. 3

Van Doesburg probeerde in De Stijl met andere woorden een antal vernieuwingen te stroomlijnen. Zijn blik was daarbij vanaf het begin gericht op schilderkunst, architectuur en vormgeving in een internationaal perspectief, in het verlengde van actuele stromingen als futurisme en kubisme. De enkele maanden eerder verschenen aankondiging van De Stijl noemde onder de buitenlandse medewerkers onder andere Picasso en Archipenko en reeds in het tweede nummer verschijnt een artikel van de Italiaanse futurist Gino Severini.

Of De Stijl de exclusieve culminatie was van al die vergaande veranderingen in de beeldende kunsten en de architectuur die zich aan het eind van de negentiende en het begin van de twin- 
tigste eeuw voltrokken, valt nog te bezien. Maar over het historische belang van de beweging bestaat inmiddels in brede kring overeenstemming vanwege het veel geprezen werk van Mondriaan, Oud en Rietveld.

In de jaren voordat Theo van Doesburg De Stijl oprichtte, was hij actief als dichter, schilder en ontwerper; verder publiceerde hij over de door hem zo vurig gewenste vernieuwing in de kunst. 4 Vanuit deze gezindheid koesterde hij al enige tijd het plan een tijdschrift op te richten. Van Doesburg hechtte - net als een aantal andere kunstenaars van zijn generatie - veel waarde aan de spirituele betekenis van kunst, waarbij Kandinsky's Über das Geistige in der Kunst (1912) grote invloed uitoefende. Volgens Van Doesburg diende kunst niet meer de natuurlijke, materiële werkelijkheid weer te geven, maar een hogere, geestelijke werkelijkheid uit te beelden. Daartoe moest de kunst in zijn ogen met de traditie afrekenen en zuiver abstract worden.

Vanaf 1915 maakte hij kennis met het werk van Mondriaan, Huszár en Van der Leck, die, elk op zijn eigen manier, een toenemende abstractie in hun beeldend werk aanbrachten. Hij legde contact met deze schilders en met de architecten Wils en Oud. Belangrijk voor het ontstaan van De Stijl was bovendien de ontmoeting van Bart van der Leck met Piet Mondriaan, die vlak voor het uitbreken van de Eerste Wereldoorlog vanuit Parijs voor familiebezoek naar Nederland was gekomen en in verband met de Duitse inval niet terug kon keren. Hun gezamenlijke verblijf in Laren en de daaruit voortvloeiende wederzijdse beïnvloeding leidden tot een nieuwe manier van schilderen, die door de immer alerte Van Doesburg onmiddellijk werd opgemerkt en geprezen. In hun werk kreeg de door hem verlangde 'nieuwe beelding' voor het eerst overtuigend gestalte.

In zijn standaardwerk over De Stijl kenschetst Jaffé het ontstaan van de beweging, voor zover het schilderkunst betreft, als een chemische reactie ten gevolge van het samenvoegen van drie elementen. 5 Ten eerste een kubistische traditie die tot Cézannes pogingen teruggaat om de natuurlijke vorm tot geometrische vormen te herleiden, een weg die vooral door Mondriaan werd ingeslagen. Verder een vernieuwing in muurschildering en mo- 
numentale kunst, wortelend in de Arts and Crafts Movement, in Jugendstil en symbolisme, met invloed van het werk van Seurat op het streven naar een objectieve beeldtaal en aandacht voor het tweedimensionale oppervlak. Daarbij noemt hij Van der Leck. Een derde element, in de eerste plaats bij Van Doesburg te vinden, is de theorievorming over expressionistische abstractie, van onder andere Kandinsky, die ten slotte tot het uitbannen van elke inhoudelijke verwijzing naar de werkelijkheid zou voeren.

De ideeën over architectuur in De Stijl waren voor een deel op die van de schilders geënt, maar moeten minstens evenzeer worden gezien in de context van Berlages vernieuwingen. Ook stonden ze onder invloed van Frank Lloyd Wright, wiens werk door de architect Van 't Hoff in Nederland werd geïntroduceerd. Hiernaast speelden meer algemene opvattingen over massaproduktie, gebruik van nieuwe materialen en grootschaligheid een belangrijke rol.

In de loop van 1917 slaagde Van Doesburg erin om Mondriaan, Van der Leck, Huszár, Oud, Wils en enkele anderen tot medewerking aan een nieuw tijdschrift te bewegen en in oktober van hetzelfde jaar verscheen het eerste nummer van De Stijl. Bij de naam van het blad moet het apodictisch gebruik van het bepaald lidwoord niet over het hoofd worden gezien: het was de bedoeling dat de kunstenaars in dit tijdschrift aantoonden wat de stijl voor de nieuwe tijd in moest houden. ${ }^{6}$

Het programma dat aan dit ideaal ten grondslag lag, valt uit de eerste jaargangen van De Stijl en uit andere publikaties van de medewerkers uit die tijd te destilleren. Het heeft een zowel destructieve als opbouwende strekking, want het oude diende in hun ogen te worden afgeschaft om plaats te maken voor het nieuwe. De idealen van De Stijl werden dan ook telkens in de vorm van begripstegenstellingen gepresenteerd.

Het uiteindelijke doel van De Stijl was het overwinnen van een onvolkomen en chaotische wereld in absolute harmonie, een utopisch ideaal dat het meest expliciet door Mondriaan werd beleden. Het belangrijkste programmapunt was een streven naar het universele tegenover het individuele. Deze tegen- 
stelling hing voor de woordvoerders van de beweging nauw samen met die van het geestelijke tegenover het materiële, van het abstracte tegenover het concrete (of het natuurlijke), van het objectieve tegenover het subjectieve en van het redelijke tegenover het gevoel.

Dergelijke vaak door elkaar heen lopende tegenstellingen zijn ten dele afkomstig uit theosofisch gedachtengoed, dat met name op Mondriaan veel invloed heeft gehad. Doorgaans wordt in dit verband ook het werk van de Larense wiskundige en 'christosoof' Schoenmaekers genoemd, bij wie de term 'beelding' veel voorkomt en verder een pleidooi voor primaire kleuren en orthogonale afbeelding. Schoenmaekers' theoretische aandeel is wel eens overschat, maar hij was zeker van belang voor de terminologie van de beweging en als katalysator in het vinden van een nieuwe beeldtaal.7

De genoemde tegenstellingen zijn ook afkomstig uit het werk van de onder kunstenaars destijds gezaghebbende neo-hegeliaanse filosoof Bolland. Daarnaast hadden Duitse kunsthistorici als Worringer en Wölfflin op vooral Van Doesburg een aanzienlijke invloed. Wilhelm Worringers Abstraktion und Einfüblung (1908) veronderstelde dat de geschiedenis van de kunst zich tussen twee uitersten bewoog: abstractie of spiritualisme versus natuur en materialisme. En Wölfflins befaamde Kunstgeschichtliche Grundbegriffe (1915) ontwikkelde eveneens een aantal begripstegenstellingen die gedurende enkele jaren door Van Doesburgs theorieën spoken. ${ }^{8}$ (Wölfflins vijf befaamde, min of meer ideaal-typische stijltegenstellingen waren (I) het lineaire tegenover het picturale; (2) vlakheid tegenover diepte, (3) gesloten vorm tegenover open vorm, (4) veelheid tegenover eenheid en $(5)$ duidelijkheid tegenover onduidelijkheid.) De in De Stijl telkens opduikende tegenstellingen worden ten slotte ook ontleend aan een aantal verspreide geschriften en pamfletten van kunstenaars uit heel Europa, naast Kandinsky's al genoemde Über das Geistige in der Kunst vooral strijdbaar proza van de futuristen.

Van Doesburg en Mondriaan, de belangrijkste theoretici van De Stijl, beroepen zich voortdurend op dergelijke tegenstel- 
lingen; met name die tussen positief en negatief, mannelijk en vrouwelijk, verticaal en horizontaal, gesloten en open vormen, veelheid en eenheid, en die van duidelijkheid tegenover het vage. Tegelijkertijd functioneren deze tegenstellingen in een dialectisch proces, waarin ze, in de synthese van een nieuwe beelding, opgeheven (zullen) zijn.

Hoewel een dergelijke hoeveelheid weinig precies omschreven begrippen verwarrend mag lijken, ontstaat er meer helderheid zo gauw de aangevoerde theorieën en argumenten naar de door De Stijl gemaakte en gepropageerde kunstwerken vertaald worden. Wie de vroege ontwikkeling van het werk van Mondriaan beschouwt, krijgt al snel een aanschouwelijke illustratie van de tegenstelling tussen horizontaal en verticaal, al verdient het misschien de voorkeur illustratie en het geillustreerde van rol te laten verwisselen. Het gaat immers om de beelding; de theorie vloeit eruit voort, zoals Van Doesburg op de eerste bladzijde van het eerste nummer verkondigt.

Hetzelfde geldt voor het proces van abstractie, dat bij beschouwing van het vroege werk van Huszár, Van der Leck, Mondriaan en Van Doesburg op een fascinerende manier duidelijk maakt, hoe ieder op zijn eigen manier de figuratieve weergave van de werkelijkheid (of in de taal van De Stijl: de natuurlijke beelding) probeert los te laten. Zo wordt een bepaalde realistisch verbeelde koe bij Van Doesburg zodanig 'omgebeeld' dat er een universeel beeld van de koe ontstaat, zoals Mondriaan een kerktoren en een pier in zee tot algemene tegenstellingen van horizontaal en verticaal herleidde. Iets dergelijks zien we in het in De Stijl ( $\mathrm{r}: 3$ (19 18)) afgebeelde Hamer en zaag van Huszár, waarin de essentiële functies van deze gereedschappen tot (horizontale en verticale) beweging worden teruggevoerd.

Het universele staat tegenover het individuele en dat betekent voor De Stijl tegelijkertijd een verwerping van het subjectieve en het gevoel. Daarmee zette deze beweging zich duidelijk af tegen het kort daarvoor opgekomen expressionisme. De universele benadering wilde ook individuele, contingente verschijnselen uitsluiten; derhalve waren ornament en eigenlijk 
elke particuliere toevoeging uit den boze. Hieronder vielen zelfs de schuine hoek en de gebogen lijn - Van Doesburg deed ze af met het pejoratief bedoelde 'barok'. Beeldende middelen waren voor De Stijl bij uitstek de rechthoek (dus de rechte lijn en de rechte hoek), de drie primaire kleuren en de niet-kleuren wit, grijs en zwart.

De principes van De Stijl zijn ook op allerlei manieren in de weergegeven opvattingen over bouwkunst terug te vinden (al bestaan er grote spanningen over de verhouding tussen schilderkunst en architectuur, zoals nog zal blijken). Allereerst wordt de aandacht van De Stijl voor massaproduktie in de bouw als een uiting van 'het universele' gezien en als verzet tegen individuele subjectiviteit. De bijdragen over architectuur willen dan ook niets weten van 'handwerk' in de traditie van Ruskin en Morris; bovendien ontwerpt men liever straten dan huizen. Af en toe vindt men in De Stijl haast provocerend de afbeelding van een vliegtuighangar of een graansilo in de Verenigde Staten, die door ingenieurs, niet door 'kunstenaars' is ontworpen. De Stijl pleit voor een consequenter gebruik van nieuwe technieken en materialen op grond van 'rationaliteit'. Ze verwerpt elk ornament. (De in die tijd opkomende Amsterdamse School krijgt het dan ook hard te verduren.) Daarnaast wordt de voorkeur gegeven aan middelen van de Nieuwe Beelding, dus rechte hoeken, een evenwichtige (maar niet symmetrische!) horizontaal-verticaalverdeling, en gebruik van primaire kleuren en wit, zwart en grijs.

In breder perspectief bezien ontstaat De Stijl in een merkwaardig vacuüm. Terwijl de wereld in oorlog verkeert en terwijl zich niet zo erg ver van de Nederlandse grens op een van de grootste slagvelden van de geschiedenis massale gruwelen afspelen, ontwikkelt een groep kunstenaars een utopisch programma dat met deze werkelijkheid wel erg weinig rekening lijkt te houden. Waar het negentiende-eeuwse vooruitgangsoptimisme elders in de wereld flink door de werkelijkheid op de proef wordt gesteld, groeit bij deze kunstenaars het geloof in een betere toekomst, zonder dat aan de overal woedende oorlog veel woorden worden vuilgemaakt. Als de wereldoorlog al eens 
in De Stijl ter sprake komt, stemt dat niet tot pessimisme over de mens; eerder klinkt er dan een bijna triomfantelijke toon op in de constatering dat de 'wereldkamp' de oude cultuur voorgoed vernietigd heeft. 9 En terwijl grootschalig georganiseerde legers elkaar elders met een rijk arsenaal aan technische verworvenheden bestoken, zien de architecten en theoretici van De Stijl in grootschaligheid en nieuwe technische mogelijkheden juist grote kansen voor een betere wereld.

Toch is De Stijl allerminst wereldvreemd en ook de internationale oriëntering van deze ontluikende beweging krijgt zodra de grenzen weer opengaan onmiddellijk gestalte. Wel zien we in het tijdschrift een soms wat abrupte afwisseling van discussies op een internationaal platform met gemopper op de directeur van een kunstacademie in Haarlem en hatelijkheden aan het adres van 'een Friesch Dagblad' of aan De Stem van Dirk Coster en zijn vrienden met hun 'tractaatjes-literatuur, dik belegd met predikantenpathos'. ${ }^{10}$

Misschien getuigt de vaststelling dat een kritische reflectie op de twijfelachtige verworvenheden van de techniek bij De Stijl ontbrak, van enige historische vertekening, aangezien een dergelijke reflectie op een door nieuwe technieken mogelijk gemaakte massavernietiging pas na de Eerste Wereldoorlog gemeengoed begint te worden. Het is de vraag of de wel vaker geuite bewering dat de Eerste Wereldoorlog voor een enorme omslag in het denken over vooruitgang heeft gezorgd, door het hieronder te beschrijven voorbeeld van De Stijl wordt bevestigd." "

In dit hoofdstuk wordt niet geprobeerd nog eens een algemeen historisch overzicht van De Stijl te schetsen. De geschiedenis van deze beweging is inmiddels op een groot aantal manieren beschreven en gedocumenteerd. Net als in het vorige hoofdstuk wordt hier eerder het elders in dit boek betoogde empirisch onderzocht en geillustreerd, waarbij een vergelijkbare beperking aan het te beschouwen materiaal zal worden opgelegd. Er wordt in beginsel uitgegaan van de in het tijdschrift De Stijl opgenomen teksten en afbeeldingen. Een beweging als De Stijl leent 
zich goed voor zo'n benadering, omdat een aantal medewerkers, met name Van Doesburg, Mondriaan en Oud, het van belang vond hun bedoelingen en nieuwe opvattingen zelf in geschrifte uit te dragen - bovendien waren ze daar ook toe in staat. Het is de taak van de kunstenaar, zo schrijft Van Doesburg in de al eerder aangehaalde inleiding op het eerste nummer,

het rein-beeldende kunstwerk voort te brengen; ten tweede: het publiek voor de schoonheid der reine beeldende kunst ontvankelijk te maken. ${ }^{12}$

Een verdere beperking schuilt in mijn exclusieve aandacht voor beeldende kunst en architectuur, terwijl De Stijl ook andere terreinen bestreek als poëzie (vooral Van Doesburg onder het pseudoniem I.K. Bonset), vormgeving (in de eerste plaats Rietveld), abstracte film (Hans Richter) en muziek en dans (Mondriaan), om nog af te zien van het min of meer artistiek bedoelde proza van Aldo Camini, het alter alter ego van Van Doesburg.

Bij de bespreking van de verzamelde jaargangen van De Stijl dienen, net als in het vorige hoofdstuk, weer drie vragen als leidraad. Ten eerste, of leden en sympathisanten van De Stijl de veranderingen in de beeldende kunst en de architectuur zelf als een of andere vorm van vooruitgang zagen en zo ja, wat die vooruitgang volgens hen dan was. Vervolgens de vraag op welke manier de leden of medewerkers van De Stijl gebruik maakten van vooruitgangsretoriek (met begrippen als 'evolutie', 'modern', 'historische noodzaak', etc.) en of dergelijke noties een rol speelden in wat eerder in dit boek een 'artistieke revolutie' is genoemd. Ten slotte wordt weer ingegaan op een vraag die niet op grond van teksten uit De Stijl kan worden beantwoord, namelijk in welke mate latere critici en kunsthistorici de veranderingen als vooruitgang interpreteerden, dus hoe De Stijl haar plaats in de kunstgeschiedenis heeft gekregen.

Er wordt hier hoofdzakelijk aandacht aan de eerste jaargangen van De Stijl besteed. Niet alleen omdat de eerste drie jaren (tot en met 1920) goed zijn voor meer dan de helft van de in dit tijdschrift gepubliceerde theoretische geschriften, maar ook 
omdat dan nog alle belangrijke deelnemers van de beweging erin zijn aan te treffen en omdat alle fundamentele ideeën in die eerste jaren al aan bod komen. Vanaf 1921 worden de theoretische houding en de énsgezindheid binnen de De Stijl-groep minder stabiel door een samenloop van inhoudelijk-artistieke ontwikkelingen en veranderende omstandigheden. Zo neemt het dadaïstische gehalte dankzij Van Doesburg snel toe en ontstaat er allengs meer vervlechting met nieuwe ontwikkelingen in andere kunstvormen als literatuur en film, en met een steeds veranderende constellatie van buitenlandse vernieuwingsbewegingen. Belangrijke medewerkers als Van der Leck, Van 't Hoff en (tijdelijk) Huszár hadden toen al met De Stijl gebroken en in I 922 volgde Oud hun voorbeeld. In deze tijd nemen ook de spanningen tussen Van Doesburg en Mondriaan toe, totdat omstreeks 192 s een definitieve breuk volgt.

Dat jaar distantieert Van Doesburg zich nog niet expliciet van de ideeën waar De Stijl aanvankelijk voor stond, maar vanaf de zevende jaargang van De Stijl, dus sinds 1926 (nummer 73/74), verkondigt hij standpunten die in de eerste jaargangen nog vernietigend door hem onder vuur zouden zijn genomen. ${ }^{3}$ In $D e$ Stijl (vII:75/76) proclameert hij het zogenaamde elementarisme om 'het statische' van de Nieuwe Beelding te overwinnen. Zijn 'Manifest-fragment' van dit nummer voert na de verworvenheden van de klassieke, de kubistische en de neo-plastische compositie het vierde stadium van de 'Elementaire (ANTISTATISCHE) CONTRA-COMPOSITIE' in, die 'behalve orthogonale, ook schuine, gecombineerde en simultaan-constructies' mogelijk maakt. (vu: 75/76(1926-1927), 38-39) In dit verband is het vermakelijk om te zien hoe Van Doesburg op het omslagontwerp voor zijn geschrift Klassiek-barok-modern, de tekst van een in 1920 gehouden lezing, het woord 'barok' nog vol minachting met een diagonale typografie afbeeldt, terwijl nu achter op het jubileumnummer van De Stijl van 1927 het woord 'Elementarisme' in grootkapitaal diagonaal wervend van het kaft schreeuwt. ${ }^{14}$

In de vanaf ditzelfde jaar verschijnende nummers van het nieuwe avantgardistische tijdschrift $i$ Io duiken vervolgens bij- 
dragen van bijna alle medewerkers van de eerste jaargangen van De Stijl op, met uitzondering dan van Van Doesburg zelf. En hoewel deze onvermoeibare gangmaker vanaf het begin de spil en organisator van de beweging is, valt hij in die latere jaren zodanig samen met het tijdschrift, dat niet meer van een echte beweging gesproken kan worden. De Stijl is dan een internationaal podium geworden voor vaak zeer uiteenlopende avantgardistische kunstenaars. Van Doesburg is de almachtige impresario van dit theater en tegelijkertijd de meest optredende artiest.

\section{De nieuwe stijl en de tijdgeest}

Dat lag anders toen De Stijl begon. Hoewel Van Doesburg in die tijd niet minder de initiatiefnemer, drijvende kracht en enige redacteur van het tijdschrift was, droegen ook anderen substantieel bij aan de theorievorming en de formulering van een artistiek programma. Verreweg het belangrijkst waren de voor alle medewerkers aanvankelijk gezaghebbende artikelen van Mondriaan, die in de eerste jaargang onder de titel 'De Nieuwe Beelding in de schilderkunst' een uiteenzetting in elf afleveringen publiceerde.

Mondriaan begon zijn verhandeling als volgt:

Het leven van den huidigen, gecultiveerden mensch keert zich langzamerhand van het natuurlijke af: het wordt al meer en meer een abstract leven.

Waar het natuurlijke (niterlijke) meer en meer 'automatisch' wordt, zien we de levensaandacht zich meer en meer op het innerlijke vestigen. Het leven van den werkelijk modernen mensch is noch op het materieele óm het materieele gericht, noch domineerend gevoelsleven, maar treedt als meer zelfstandig leven van den zich bewustwordenden menschelijken geest op. (I:I (1917), 2)

In deze zinnen springt meteen in het oog hoezeer Mondriaan in (deels tot hegeliaanse dialectiek, deels tot de theosofie herleid- 
bare) begripstegenstellingen denkt: het 'natuurlijke' staat tegenover het (allengs meer) gecultiveerde, dat toenemende abstractie en innerlijkheid impliceert als reactie op het uiterlijke en empirische van het 'natuurlijke'. Het materiële en het gevoel dienen overwonnen te worden in een synthese van lichaam en ziel tot 'geest'.

Een dergelijke ontwikkeling leidt in de kunst uiteindelijk tot de Nieuwe Beelding, die Mondriaan voor ogen staat: geen afbeelding van een zichtbare 'materiële' werkelijkheid, noch een uitdrukking van hoe die werkelijkheid subjectief ervaren wordt, maar van wat in het verlengde van het Duitse idealisme een directe weergave van het wezen van de werkelijkheid genoemd zou kunnen worden. Het gaat de Nieuwe Beelding niet om uitbeelding van de fenomenale wereld, maar om een belangeloze, objectieve contemplatic van het noumenale, om 'de verschijning der aesthetische idee, op zichzelf', waarbij Mondriaan ter verduidelijking naar de esthetische beginselen van Schopenhauer verwees. 15

De metafysisch-historiserende toon van het aangehaalde openingsfragment is representatief voor veel artikelen uit De Stijl: er worden een bepaalde ontwikkeling en een bepaalde tijdgeest geconstateerd, die onvermijdelijk tot de Nieuwe Beelding zullen leiden. Zo schrijft Huszár in een onder andere door Bolland geïnspireerd stuk:

Als wij den geestelijken groei van het menschelijk zijn in het Al beschouwen, zooals die zich ontwikkeld heeft tot op beden, dan zien wij overal in het geestelijk leven bet algemeene streven naar het redelijk denken of naar de bewustwording van den mensch; dit ontplooit zich steeds meer, en tracht overal zich te realiseeren en te beelden. (n: $1(1918), 8)$

Wat redelijk denken en bewustwording inhouden, is voor de lezer van De Stijl wel duidelijk, namelijk de geestesgesteldheid die uit de Nieuwe Beelding spreekt. De architect Oud verkondigt in zijn pleidooi voor een universele, 'machinale' bouwkunst: 
Waar de architectuur reeds langs machinalen weg tot beelding komt (Wright), de schilderkunst in consequentie tot deze beeldingswijze gedreven wordt, verschijnt vanzelf een eenheid in zuivere uitdrukking van den tijdgeest. (r:3(1918), 26)

Die uit het hegeliaanse gedachtengoed afkomstige 'tijdgeest' blijft bij De Stijl geen vage kreet. Net als Oud zien Mondriaan en Van Doesburg de in hun tijd steeds belangrijker wordende mechanische kracht als een meer universele vervanging van individuele 'natuurlijke' kracht. Mondriaan illustreert de veranderende tijdgeest verder met de mode, waarin hij een 'typeerende verstrakking van vorm en kleur' ziet, 'welke teekenen zijn van het gaan van de natuur àf'. En als liefhebber van de moderne dans zag de 'dansende madonna' (zoals zijn vrienden hem destijds in Laren noemden) de rechte lijn in tango, step en boston de plaats innemen van het ronde gezwier uit de klassieke wals. ${ }^{16}$

De aandacht voor de tijdgeest weerspiegelt het inhoudelijke belang van het algemene, het universele, dat De Stijl zo hoog in het vaandel voert. Het universele dient tot uitdrukking te worden gebracht en daarom moet afstand worden genomen van de empirische, 'natuurlijke' voorstelling. Het 'essentieele van alle beeldende schoonheidsontroering' wordt door abstractie van kleur en vorm bereikt, door 'exacte beelding van enkel verhouding'. Weliswaar bedient men zich in de Nieuwe Beelding nog altijd van kleur en vorm, maar deze zijn radicaal geabstraheerd tot primaire kleuren en niet-kleuren en anderzijds tot rechte lijn en rechte hoek of, zoals Mondriaan het noemt, 'tweeheid van stand'. (I:I (1917), 3-4; I:3 (1918), 29)

Het artistieke programma was bij het verschijnen van de eerste nummers van De Stijl overigens bepaald geen afgerond geheel. Noch Mondriaan, noch andere schilders werkten al in de trant van de doeken die vanaf de jaren twintig door Mondriaan gemaakt zouden worden en die achteraf als het voor De Stijl meest representatieve werk worden gezien. Telkens is de worsteling met het loslaten van de figuratieve ('natuurlijke') werke- 
lijkheid voelbaar. Zo bespreekt Van Doesburg vlak na het aangehaalde stuk van Mondriaan de in dit nummer gereproduceerde Ezelrijders van Van der Leck (I:I (I9I7), II), waarvan de 'aanleidende gegevens [...] ezelrijders in Spaansch landschap' zijn. Vergelijkbare besprekingen van schilderijen en sculptuur keren aanvankelijk geregeld terug. Het iconoclasme van De Stijl kwam niet als een donderslag bij heldere hemel; het was een moeizaam bevochten houding.

Het uitgangspunt van de medewerkers van De Stijl was het nastreven van een geestelijke en universele harmonie. Waar dit streven in de schilderkunst tot abstractie en de bovenbeschreven beeldtaal voerde, lag dit in de architectuur aanmerkelijk gecompliceerder, zoals nog naar voren zal komen. De Stijl probeerde op uiteenlopende manieren het samengaan van schilderkunst met architectuur (en andere kunstvormen) te stimuleren, maar dit leidde vanaf het begin tot onderlinge competentieproblemen tussen beide gebieden.

$\mathrm{Al}$ in het eerste nummer blijkt dit uit Van der Lecks artikel, 'De plaats van het moderne schilderen in de architectuur', waarin hij nadrukkelijk meer ruimte voor de schilderkunst opeist. Het artikel is ongetwijfeld ook een reactie op zijn persoonlijke ervaringen als interieurontwerper met vooral Berlage; Van der Leck vond het weinig aantrekkelijk om op te moeten treden als 'een soort luxe-huisschilder' en het kleurgebruik te bepalen 'voor een omgeving waar [...] in monumentaal opzicht geen eer aan te behalen was'. ${ }^{17}$ In hetzelfde nummer van De Stijl situeert Mondriaan de schilderkunst eveneens boven de architectuur, omdat de schilderkunst 'de meest consequente uitbeelding van enkel verhouding' is:

In schilderkunst kan de dualiteit der verhouding los van elkander geplaatst worden, betgeen in de bouwkunst of beeldhouwkunst onmogelijk is. Hierdoor kan de schilderkunst het zuiverst 'beeldend' zijn. (I:I (1917), 3-4)

Een aantal vernieuwingen uit de schilderkunst had onmiskenbaar invloed op beoogde veranderingen in de architectuur, zoals 


\section{Vernieuwing in schilderkunst en architectuur: De Stijl}

toepassing van primaire kleuren, van de evenwichtige verhouding tussen horizontale en verticale elementen, of het vermijden van de schuine hoek (zoals het aflopende dak). Andere vernieuwingen hadden echter een meer voor de bouwkunst specifiek karakter. Zo had het bepleite gebruik van nieuwe technieken, onder andere staalconstructies en betonbouw, geen onmiddellijke picturale tegenhanger in de schilderkunst. Ook de propaganda voor machinale produktie was eerder gericht tegen handwerk in de traditie van Ruskin en Morris en was eerder een teken van enthousiasme voor het futuristisch elan dan een uitwerking van Mondriaans neoplastische beginselen.

Het is niet moeilijk een uitvoerig vocabulaire van vooruitgangsbegrippen in de artikelen en beschouwingen uit De Stijl aan te wijzen. Om te beginnen duikt telkens de genoemde idee van de tijdgeest op, de idee dat de geschiedenis een bepaald stadium heeft bereikt, dat weliswaar nog niet door iedereen ten volle wordt begrepen, maar dat zich niettemin ontegenzeggelijk aankondigt in talloze veranderingen en dat zich het meest zuiver zal realiseren in de Nieuwe Beelding.

Wanneer Mondriaan dan ook spreekt van de werkelijk moderne mens, bedoelt hij in de eerste plaats met dat 'werkelijk' iets van metafysische aard. Hij wijst aldus niet op iemand die zich mee laat slepen door contingente, contemporaine gebeurtenissen, maar op iemand die modern is omdat hij beseft wat wezenlijk is voor de cultuur van zijn tijd. Die eigen tijd, zo meent De Stijl, is het resultaat van een geestelijke ontwikkeling of, in de al aangehaalde woorden van Huszár, 'geestelijke groei van het menschelijk zijn in het Al'. De werkelijk nieuwe kunst vindt echter vaak weinig weerklank omdat men zo moeilijk met de traditie breekt en dus de vooruitgang niet bij kan benen. Het is weer dit door Koselleck als gelijktijdigheid van het ongelijktijdige bestempelde besef dat bovenkomt wanneer Paul Colin Jean Cocteau citeert:

Lorsqu'une oeuvre semble en avance sur son époque, c'est simplement que son époque est en retard sur elle. (II:I I (1919), 127) 


\section{Vernieuwing in de architectuur}

Het lijdt geen twijfel dat de architecten van De Stijl de door hen gepropageerde nieuwe bouwkunst zelf ook anderszins in termen van vooruitgang beschouwden. Dat blijkt al uit twee artikelen uit het derde nummer van de eerste jaargang. In 'Kunst en machine' plaatst Oud de ontwikkeling van de moderne kunst in een maatschappelijke context:

Groote kunst staat in oorzakelijk verband met bet maatschappelijk streven van den tijd. De zucht tot ondergeschikt maken van bet individueele aan bet gemeenschappelijke vindt men in het dagelijksch leven, evenals in de kunst, gereflecteerd in de behoefte tot organiseeren van individueele elementen tot groepen: vereenigingen, bonden, maatschappijen, trusts, monopolies, enz. ${ }^{18}$

Jan Wils doet een aantal bladzijden verder in 'De nieuwe bouwkunst' (1:3 (19r8), 3r-33) eenzelfde observatie (en voegt aan die groepen ook de miljoenenlegers toe; niet als wenselijke ontwikkeling overigens, maar als blijk van de onvermijdelijke gang van zaken, die zich overal manifesteert).

De architect moet volgens Wils voldoen aan moderne eisen van schoonheid en doelmatigheid. 'Merkwaardig' genoeg zijn er 'dank zij de technische vooruitgang materialen gevonden' die aan deze eisen kunnen voldoen, zoals beton, staal, spiegelglas en naadloze vloer- en wandconstructies. Men is echter nog 'angstig' om ze consequent toe te passen en gebruikt ze 'naar den aard van oude bekende materialen (steen en hout)', wat net zo vreemd is als de

ongerijmdheid, dat wij, met onze geheel gewijzigde levensinzichten, verkeeren in buizen met een indeling, die nog uit de Lodewijk-tijd afkomstig is. (1:3 (1918), 32-33)

De Stijl stond in de bouwkunst een serie-matige, grootschalige en gestandaardiseerde produktie voor met behulp van de 
nieuwste materialen. Zij meende hierin voorop te lopen ten opzichte van andere vooruitstrevende groeperingen. Zo klaagde Oud er in 1918 over dat op het pas gehouden Woningcongres niet alleen de architecten, maar zelfs de marxistische arbeiders zich bleven verzetten tegen de vaststelling van standaardtypen in de woningbouw. Van een architect kon hij zich nog voorstellen dat die zich niet 'zijn eigen deur en raam [...] zonder slag of stoot ontnemen laat', maar de marxisten hadden toch op zijn minst gevoelig moeten zijn voor de aan de gemeenschap toekomende kostenbesparing die de massaproduktie met zich mee zou brengen, terwijl er in esthetisch opzicht ook winst geboekt kon worden. (I:7 (1918), 78)

Architecten van De Stijl ondernemen enkele malen een poging de door hen gewenste vernieuwingen van een nieuwe voorgeschiedenis te voorzien. Zo probeert Jan Wils het voor De Stijl belangrijke uitbeeldingsmiddel van harmonie zonder symmetrie begrijpelijk te maken met behulp van een veelomvattend (maar weinig uitgewerkt) ontwikkelingsmodel van Adolf Meyer, een medewerker aan het Bauhaus en assistent van Gropius. In 'Symmetrie en kultuur' (I:I 2 (1918), 137-140) beschrijft Wils de ontwikkeling van het verschijnsel symmetrie in zeven stadia. Het vertrekpunt is de radiale symmetrie, 'in drie doorsneden gelijk ontwikkeld', van het regelmatige kristalstelsel. Deze symmetrie correspondeert in de natuur met 'de eicel, de mikrokokken' en in de cultuur met de kegelbal en de kubus. Het volgende stadium is radiaal symmetrisch en in twee doorsneden gelijk ontwikkeld (waarmee de bacil en de draadwieren respectievelijk de ton en de trommel corresponderen), en zo door tot de volkomen asymmetrie. Hiermee komen - na planten en lagere en hogere diersoorten in vorige stadia - de mens respectievelijk 'de ingewikkelde machines' overeen.

Dit model laat Wils vervolgens ongeremd op de geschiedenis van de architectuur los, te beginnen bij de ronde tempel van de Grieken. Het wordt een curieuze, niet altijd even begrijpelijke geschiedenis van het bouwen, met grote sprongen en wonderlijke ad hoc opmerkingen. Een citaat: 


\section{Steeds mooier}

Deze gebouwen [middeleeuwse kerken] zijn monosymmetrisch en bevinden zich, volgens bovenstaande tabel, op de ontwikkelingshoogte van het hoogere dier.

Wat voor bet goddelijke bouwwerk geldt is even waar voor bet profane.

Op de ontwikkelingshoogte van de plant staan b.v. de kapberg (de open hooiplaats) en de molen.

Monosymmetrisch zijn de meeste openbare gebowwen; zij staan dus niet hooger dan het hoogere dier. (I:I 2 (I91 8), I 39)

Het is niettemin duidelijk waar deze ontwikkeling uitkomt: 'Het volstrekte leidt tot het asymmetrische.' (I: 12 (I9I 8), I 40)

De gedachten van Wils over de geschiedenis van de architectuur hebben hier een evolutionair karakter, maar in het al geciteerde De nieuwe bouwkunst bezigt hij het meer revolutionaire idioom van de breuk met de geschiedenis, dat veel avantgardebewegingen kenmerkt:

Iedere bouwkunst, die zou trachten, met de momenteel ten dienste staande middelen en met de bestaande behoeften, voort te bouwen op overleveringen, onverschillig welke, is daarom reeds in beginsel ten doode opgeschreven. (I:3 (1918), 33)

Ook bij Van 't Hoff zijn beide opvattingen terug te vinden. Uit diens 'Architectuur en haar ontwikkeling' spreekt een evolutionaire houding, maar tegelijkertijd meent hij dat we 'ons los [moeten] scheuren van [...] het werk der dooden'.19

De architecten van De Stijl formuleerden hun opvattingen onomwonden in termen van vooruitgang. Ze hielden een pleidooi voor nieuwe technieken en procédés, een nieuwe vormentaal die hierdoor mogelijk werd, voor een grootschaliger en meer rationele organisatie en voor standaardisering in het bouwen. Hun overwegingen sloten aan op een negentiendeeeuws, positivistisch geloof in technische, sociale en wetenschappelijke vooruitgang.

Zo gauw men zich echter afvraagt waar deze vooruitgang bij 
De Stijl nu concreet uit bestaat, rijzen er problemen. Allereerst was het al in 1919 tot een breuk gekomen met Wils en Van ' $t$ Hoff, zodat het bepaald niet vanzelfsprekend is hun (weinig omvangrijke) werk uitsluitend in de context van de vernieuwingen van De Stijl te interpreteren. Verder verliet ook Oud na enkele jaren De Stijl naar aanleiding van een meningsverschil met Van Doesburg, dat een fundamentele kwestie aan het licht brengt. ${ }^{20}$

Volgens afspraak zou Van Doesburg in 1921 de kleurontwerpen voor door Oud gebouwde huizenblokken in het Rotterdamse Spangen verzorgen. Oud reageerde aanvankelijk enthousiast op de gewaagde plannen van Van Doesburg, maar kort daarop nam hij geleidelijk afstand van de zwarte rechthoeken en felle kleuren die op de gevels zouden moeten verschijnen, waarschijnlijk onder invloed van de scepsis van zijn opdrachtgevers. De reacties van de van nature toch al niet erg omzichtige Van Doesburg waren furieus in dit conflict tussen de theoretische idealen van De Stijl en de praktische eisen die in de werkelijkheid kennelijk aan architectuur werden gesteld.

Oud was sinds 191 8 gemeentearchitect van de stad Rotterdam. Hij leed naar eigen zeggen onder de geringe vrijheid die zijn opdrachtgevers hem lieten, maar was niettemin bereid in vergaande mate rekening te houden met de hem opgelegde beperkingen. Jaren later vinden we in De Stijl nog sporen terug van woede en teleurstelling over dit door Van Doesburg als verraad gevoelde, maar toch alleszins begrijpelijke opportunisme. Nog in 1925 verwijt Van Doesburg de 'twijfelarchitect Oud' zich te hebben bekeerd

tot den Liberty-Wendingenstijl (men zie den cottagebouw 'Oud-Mathenesse' te Rotterdam en de decoratieve gevelarchitectuur van het café 'De Unie').

[...] Wanneer men zich den eerlijken aanvang van dezen architect her/r]innert, moet men zich er over verwonderen, hoe, door de en-gros-practijk, de destijds gehuldigde zakelijkheid in commis-voyageursgeest ontaardde. ${ }^{21}$ 
Er zijn weliswaar enkele onder De Stijl ressorterende ontwerpen gerealiseerd (naast interieurs natuurlijk in de eerste plaats het Rietveld-Schröderhuis uit 1923/1924), maar door de jaren heen blijken er toch te veel wetten in de weg te staan en praktische bezwaren. Zo beperkt het resultaat van de op zich vruchtbare samenwerking tussen Van Eesteren en Van Doesburg in de jaren twintig zich hoofdzakelijk tot het maken van maquettes. Veelzeggend is de houding van Le Corbusier, die in het najaar van 1923 ongeschoren en in werkkleding op de opening van de Rosenberg-tentoonstelling 'Les architectes du groupe de Stijl' verscheen, omdat hij naar eigen zeggen rechtstreeks van de bouwplaats kwam. Le Corbusier, die bouwde ook. ${ }^{22}$

Het behoeft eigenlijk geen betoog dat degenen tegen wie De Stijl zich afzette - zoals de aanhangers van de Amsterdamse School en de medewerkers van Wendingen-zelden van mening waren dat deze beweging iets aan het moderne bouwen bijdroeg. Ook de leden van het Bauhaus in Weimar betoonden zich sceptisch. Tussen 1920 en 1923 had Van Doesburg hier tijdens zijn nimmer onderbroken wervingsactiviteiten steun en aansluiting proberen te vinden. Hoewel enkele leden van het Bauhaus cursussen bij Van Doesburg volgden, bleven de deuren voor hem gesloten - vooral vanwege zijn polemische zendingsijver, zijn kritiek op de organisatie en op Gropius. Eind jaren twintig werd de Nederlandse bijdrage aan vooruitgang in de architectuur eerder aan Oud en het Nieuwe Bouwen (Merkelbach, Duiker, Van der Vlugt) toegeschreven dan aan de toch grotendeels theoretisch gebleven activiteiten van De Stijl.

\section{Vernieuwing in de schilderkunst}

In de beschouwingen over schilderkunst staan vooruitgangsideeën veel minder in het teken van maatschappelijke ontwikkeling dan bij de artikelen over architectuur, een kunstvorm die nu eenmaal moeilijk los van sociale, economische en technische veranderingen kan worden besproken. Het verschil in opvatting over vooruitgang bij schilders en architecten weerspiegelt 
het onderscheid tussen beide groepen goed. Zo vertoont het maatschappelijk engagement van de (bouwende) architecten Oud, Wils en vooral Van 't Hoff een voortdurende onderhuidse spanning met de houding van andere leden van De Stijl.23 In politiek-maatschappelijk opzicht distantiëren de schilders van De Stijl, met name Mondriaan en Van Doesburg (die zich wel veel met architectuur bezighield, maar zonder te bouwen), zich van elke ideologie. Kapitalisme en socialisme zijn voor hen te 'materialistisch'. De Nieuwe Beelding in de schilderkunst beoogt in de eerste plaats een 'geestelijke groei', zo wordt steeds beklemtoond. En hoewel een dergelijke groei - zeker bij Mondriaan - utopische trekken heeft, wordt nooit duidelijk hoe een toekomstige utopie concreet gestalte zal moeten krijgen.

Die groei impliceert in de dialectische denktrant van De Stijl in elk geval dat steeds meer afstand wordt genomen van het $n a-$ tuurlijke. Feitelijk betekent dat in de schilderkunst het figuratieve, de nabootsing van de (fenomenale) werkelijkheid, maar het begrip heeft ook een filosofische lading, en wel een dubbele. Enerzijds het 'materiële' (ten gevolge van de gangbare dichotomie tussen geest en lichaam), anderzijds in de zin van de natuuropvatting van de verlichting, volgens welke de natuur beheerst en overwonnen dient te worden. Zo haalt Mondriaan instemmend Voltaire aan, wanneer die beweert dat 'de mensch zich vervolmaakt naarmate hij zich van de natuur verwijdert'. (I:I I (I918), 127)

Het gaat bij De Stijl om een evenwicht tussen het innerlijke en het uiterlijke, tussen het geestelijke en het natuurlijke, om een aanvankelijk individueel rijpingsproces dat even langzaam als zeker tot een universele harmonie zal leiden en zo de nieuwe tijdgeest tot uitdrukking zal brengen. Mondriaan heeft het over

een groote klimming in bet subjectieve in den mensch (evolutie) m.a.w. er bestaat bewustzijnsgroei, bewustzijnsverruiming. Het subjectieve blifft wel het subjectieve, doch het verliest in subjectiviteit naarmate bet objectieve (universeele) zich ontwikkelt in het individu. Als de groote sprong (denk aan mutatie) van bet subjectieve tot bet objectieve, 


\section{Steeds mooier}

van het individueel-zijn tot het universeel-zijn eenmaal gemaakt is, houdt het subjectieve eerst op te bestaan, ${ }^{*}$ doch daarvòor vertoont zich een graadverschil in subjectief-zijn. Dit graadverschil nu is de oorzaak van het verschil in kunstuiting: door dit graadverschil is de niewwe beelding, als meest direkte aesthetische openbaring van bet universeele, mogelijk in een nog subjectieven tijd. ${ }^{24}$

Uit dergelijke zinnen spreken verschillende noties over ontwikkeling en vooruitgang: hegeliaans - door Bolland gefilterd ontwikkelingsdenken (bewustzijn, de dialectische verhouding van het subjectieve en het objectieve), negentiende-eeuwse evolutietheorie en reminiscenties aan neoplatoons en gnostisch denken (graadverschil in zijn, esthetische openbaring, bewustzijnsverruiming), het soort amalgaam dat ook opduikt in $D e$ Geheime Leer van Mevrouw H.P. Blavatsky, al is het Hegelgehalte in deze destijds veel gelezen theosofie veel geringer, of zo men will: meer verborgen. Deze componenten van het evolutiebegrip illustreren, hoe veelomvattend Mondriaans utopische idealisme was: 'ontwikkeling' voert bij hem tot een geheel nieuwe mens en een geheel nieuwe wereld. ${ }^{25}$

Ook bij Van Doesburg zien we verschillende noties over de geschiedenis van de schilderkunst bestaan. In het zesde nummer van de eerste jaargang plaatst hij een bevlogen betoog van mejuffrouw Edith Pijpers, die een reeks bezwaren tegen de moderne beeldende kunst - lees: De Stijl-uiteenzet. Van Doesburg laat dit volgen door een verweerschrift van eigen hand, waarin hij het te berde gebrachte uitputtend behandelt. De geschiedenis leert ons, zo schrijft hij, dat er steeds sprake is van zelfontplooiing van de geest. Dit is weer een hegeliaans aandoende uitdrukking. Genoemde zelfontplooiing brengt volgens Van Doesburg vernieuwingen met zich mee, die velen angst aanjagen. Maar deze angst is niet anders, zo gaat hij nu in een negentiende-eeuws positivistische toonzetting verder, dan de angst van de primitieve mens voor onweer en bliksem, een angst die dankzij de wetenschap is overwonnen. (1:6 (1918), 67)

'Uiteengevallen is deze moderne tijd en nog uiteengevallener 
Vernieuwing in schilderkunst en architectuur: De Stijl

zal hij worden,' zo haalt Van Doesburg mejuffrouw Edith Pijpers aan en hij vervolgt dan vol enthousiasme:

Gelukkig! Het is niet deze tijd die uiteenvalt, maar het is juist de oude tijd, de oude kultuur, de schijnkultuur, welke op emotie, geloof en nuance gegrondvest was; de oude tijd, welke een kunst voortbracht met schijnlicht, schijnwarmte (in de schilderkunst was deze warmte voor driekwart lapis lazzuli, kraplak, omber, gebrande terra sienna) schijndiepte, schijnverhevenheid, schijninnigheid en schijngevoeligheid, een kultunr die als resultaat eindigt in één groot schavot.

De vormen van de oude kultuur vallen uiteen omdat het wezen van een nieuwe kultuur reeds innerlijk in de menschheid aanwezig is. De openbaring van dit conflict is de wereldkamp dien wij thans medemaken. Openbaren doet de nieuwe kultuur zich door enkelen. Zij zijn de dragers van de nieuwe wereld, een nieuwen tijd. De schijn wordt voor het wezen verwisseld. De vaagheid wordt bepaaldheid. Nuance wordt kleur. Schijnruimte wordt ruimte. Schijndiepte, diepte. Emotie, bewustzijn. Drift, rede. Oorlog, recht. Natuur, stijl. (1:6 (1918), 68)

Aan deze profetische, op een hamerende peroratie uitlopende retoriek, waarin we de soms wel eens wat slordig schrijvende Van Doesburg op zijn best zien, ligt weer de idee van de tijdgeest ten grondslag, maar dan wel in een dynamische gestalte, als een voortschrijdende, of beter: zich voortdurend ontwikkelende, tijdgeest die de oude vormen afwerpt. Overigens kunnen de hier genoemde verouderde uitingen van 'emotie, geloof en nuance' beter niet als cultuurfilosofische categorieën worden opgevat, maar in de eerste plaats als verwijzend naar de door Van Doesburg verworpen beeldtaal van respectievelijk expressionistische, symbolistische en impressionistische - kortom, nog figuratief werkende - kunstenaars.

Van Doesburgs woorden vertegenwoordigen daarnaast bij uitstek het avantgardistische taaleigen van de breuk, dat her- 


\section{Steeds mooier}

haaldelijk in De Stijl blijft opduiken. Spreekt hij in de 'Inleiding bij den tweeden jaargang' al van een 'sprongsgewijze kunstontwikkeling' die een 'gansch nieuwe beeldingswijze ten gevolge moest hebben', op de volgende bladzijde, in 'Manifest I van “De Stijl", 1918', heet het:

1. Er is een oud en een nieuw tijdsbewustzijn.

Het oude richt zich op het individueele.

Het nieuwe richt zich op het universeele.

De strijd van het individueele tegen het universeele openbaart zich, zoowel in den wereldkamp als in de kunst van onzen tijd.

[...]

5. Traditie, dogma's en de overheersching van het individueele (het natuurlijke) staan deze realiseering Ivan het nieuwe tijdsbewustzijn/ in den weg. ${ }^{26}$

Vervolgens roepen de ondertekenaars op, alle belemmeringen voor de nieuwe ontwikkelingen op te ruimen.

In 'De dood der modernismen', een artikel uit 1925 , beklemtoont Van Doesburg het breukkarakter van het artistieke project van De Stijl nog duidelijker. Hier distantieert hij zich van "het "moderne" of de "avant-garde" (voorhoede van het nieuwe)'. Kennelijk is een plaats in de voorhoede hem niet genoeg, hij wil al tot de toekomst behoren. Van Doesburg richt hier zijn pijlen allereerst tegen het door hem inmiddels geminachte, in Italië met het fascisme gelieerde futurisme, maar hij probeert ook afstand te nemen van andere vernieuwingsbewegingen, waarvoor de breukretoriek heel geschikt blijkt te zijn:

Er bestaat dus behalve 'het niewwe' ook nog een bedriegelijk namaak: het quasi- of pseudo-niewwe. Naast het oude, het 'oude in nieuwen vorm', het moderne. In het 'moderne' is ook, al betreft bet slechts den vorm, een zeker percentage nieuwe mentaliteit, doch dit percentage is zoo gering, dat het nooit tot $100 \%$ = mutatie kan opklimmen, en plotseling, volledig, 'nieuw' kan worden. (vI:9 (1925), 123) 
Het nieuwe is volstrekt anders, en dat doet de meesten terugschrikken, net als de eskimo, zo verkondigt Van Doesburg op de volgende bladzijde, die, voor het eerst in de beschaafde wereld, in Londen een verkoudheid opliep en meteen weer naar huis wilde. (Historisch! voegt hij er zekerheidshalve aan toe.)

$\mathrm{Bij}$ Mondriaan vinden we vergelijkbare opmerkingen over een noodzakelijk geachte breuk met de traditie. In de vijfde jaargang schrijft hij (waar op de bladzijde ernaast de foto van een aan diagonalen hangend kabelbaantje is te zien, met als toelichting slechts 'Luchttrein Kohlernspoorbaan in Tirol'), dat 'met het oude materiaal het nieuwe niet [is] te bouwen'. (v:3 (1922), 47) En in het laatste nummer van het jaar, een anthologie, staat:

L'ancien ne nuit qu'en tant qu'il met obstacle au nouveau. [...] N'oublions pas que nous sommes à un tournant de la culture, à la fin de tout ancien: la séparation des deux est absolue et définitive. (v:1 2 (1922), I 80-I 8 I, vGL. vI:6/7 (1924), 86-88)

Ondanks de geregeld terugkerende accentuering van het breukkarakter in de ontwikkeling van de schilderkunst getuigt de historische plaatsbepaling die de medewerkers van De Stijl in hun tijdschrift betrachten, echter meestal van een zeker continuïteitsdenken. Zo wijst Mondriaan in zijn 'De Nieuwe Beelding in de schilderkunst' al in de eerste jaargang op voorlopers van De Stijl, die de 'visueele lichamelijkheid der dingen in de beelding' verbraken, namelijk Cézanne, Van Gogh en kubisten als Picasso. In het proces dat ten slotte op het 'tot bepaaldheid stellen' van de kleur zal uitlopen, is Cézannes poging om vorm door kleur uit te beelden een stap in de goede richting, zoals ook Van Goghs 'uitdrukkelijk beelden der lijn (contour)' dat is. Bij de kubisten worden vorm en kleur autonoom - ze verschijnen, in de woorden van Mondriaan, 'op zich zelve'. Daarmee komt de compositie op de voorgrond, die uiteindelijk in de volkomen abstractie van de Nieuwe Beelding zelf wordt afgebeeld. (I:4 (1918), 42-44)

Deze ontwikkeling heeft een noodzakelijk karakter, zo be- 
toogt Mondriaan een aantal jaren later in 'De huif naar den wind', een stuk waarin hij zich afzet tegen de verslapping van veel medevernieuwers. Het staat vast, zo verzekert hij:

dat evolutie der kunst wel bestaat en is ontwikkeling en geen teruggang. Dat abstracte kunst, ontwikkeld nit naturalistische, onmogelijk tot zijn oorsprong terug kan komen. Abstracte kunst kan alleen evolueeren door consequente doorvoering. Zoo kan zij komen tot het zuiver beeldende, dat in bet Neo-Plasticisme bereikt is. (vi:6/7 (1924), 88)

Ook Vilmos Huszár wijst op dit noodzakelijke karakter van de door De Stijl gepropageerde ontwikkeling. In een van zijn Aesthetische beschouwingen, waarin hij een monumentaal werk van Van der Leck vergelijkt met een naar zijn idee verouderde schildering van R.N. Koland Holst, geett hij at op een aantal contemporaine ontwikkelingen:

Even vlug als dit alles ontstaat, zal het ook weer verdwijnen. Dat leert de practijk: Wiener Secession, Jugendstil, Amsterdamsche school enz. enz. De sterken van deze richtingen natuurlijk uitgezonderd, want deze[n] staan niet buiten de logische ontwikkeling van onzen monumentalen stijl-groei [...].

$[\ldots]$ [W]e zijn nu verder, de futuristen en cubisten hebben heel wat schoongeveegd trots tegenstand en belemmering. De tegenstanders trekken ten slotte aan bet kortste eind, want de ontwikkeling gaat zijn gang. (I:7 (1918), 80, 84)

Huszár doet in ditzelfde artikel (dat overigens aan het begin verschijnt van een uiterst succesvolle periode van de Amsterdamse School) net als Mondriaan een beroep op directe voorgangers. De 'weldra doorbrekende architecturale schilderkunst' volgt een ontwikkelingslijn die 'via het Impressionisme, naar het pointillisme en futurisme over het kubisme, naar de nieuwe beelding' loopt. (I:7 (1918), 82)

In een van de bijdragen van de niet altijd even helder formule- 
rende futurist en 'wetenschappelijk kubist' Gino Severini wordt eenzelfde recente geschiedenis tot voorgeschiedenis gemodelleerd, deze keer beginnend bij het symbolisme van Mallarmé, via de impressionisten, die echter nooit in staat waren 'in den vorm dezelfde evolutie waar te maken' als in de kleur. Toch waren de impressionisten 'baanbrekers', omdat ze het godsdienstige, het allegorische en het mystieke terzijde schoven. Tot slot belanden we volgens Severini bij verschillende vormen van kubisme, van Braque, van Picasso en van hemzelf. (II:3 (1919), 25-27)

In de optiek van Van Doesburg lag dit kubisme op dat moment kennelijk nog dicht genoeg bij wat De Stijl beoogde, al zal zijn behoefte aan aansluiting bij de buitenlandse avant-garde hem ten opzichte van de Italiaanse voorhoede-kunstenaar toen wellicht wat ruimdenkender hebben gestemd. Voor alle duidelijkheid voegt hij wel een noot toe bij een opmerking van Severini over de inmiddels tot stand gekomen onderlinge invloed van verschillende vlakken op elkaar, namelijk: 'Wat in de "Nieuwe Beelding" voor het eerst "op de wijze der kunst" tot uitdrukking kwam. Red.' (Ir:3 (1919), 26, noot 2)

Een paar jaar later is Van Doesburg aanmerkelijk zuiniger in zijn waardering voor het dan reeds tamelijk succesvolle, zij het artistiek tanende kubisme. In 'Het kubistisch probleem[,] zijn gronden en zijn consequenties', een reactie op twee studies over het kubisme, door Daniel Henry en Maurice Raynal, blijken zijn reserves allereerst uit te gaan naar het feit dat men de Nieuwe Beelding niet als de volgende - en inmiddels gezette stap heeft willen zien. ${ }^{27}$ Raynal noch Henry bezitten bijvoorbeeld

den moed, de noodzakelijkbeid te erkennen van een [...] totaal nieuwe beeldingswijze als consequentie der kubistische problematiek. (IV: 10 (1921), 145)

Van Doesburg begint ermee beide schrijvers als buitenstaanders te diskwalificeren, omdat ze zelf geen schilder zijn. Na nog een opmerking over de 'boksersmoraal' van de kritiek gaat hij in- 
houdelijk in op hun werk. In de volgende analyse blijkt hij het kubisme telkens op te vatten als een tussenstadium. Zo onderschat Henry de grote verdienste van het kubisme in het doorbreken van de vorm, hij beklemtoont juist het driedimensionale karakter van kubistische werken en zet zich af tegen abstraherende tendenties, die hij tot decoratieve kunst degradeert. Ten onrechte bespeuren Henry en Raynal niets van de 'vormlooze kleurbeelding', die in het kubisme een eerste aanzet krijgt, maar pas later bereikt zou worden. Beiden 'denken zich de kunst niet in hare ontwikkeling, maar in haar traditioneele verschijning'. (IV: IO (I92I), I48)

De 'continueerende evolutie in den menschelijken geest' die door de Nieuwe Beelding wordt uitgedrukt, is als ontwikkeling 'even noodzakelijk als gezond'. (IV:Io (1921), I49) Zij heeft het kubisme achter zich gelaten. Maar wie ziet dat in? Bijna alle geschriften over moderne kunst in Frankrijk, Duitsland en Italië (het meer traditionele Engeland telt voor Van Doesburg hoe dan ook nooit mee) lijden onder wat hier zo fraai 'consequentieschuwheid' wordt genoemd. (IV:I 2 (1921), 174)

Van Doesburg heeft belangstelling voor (en belang bij) een ontwikkelingsperspectief. Zo onderstreept hij ten aanzien van 'post- en neo-impressionisme' de intuïtieve opheffing van de 'vorm als organische geslotenheid' en verklaart hij het gebruik van letters en cijfers bij Picasso en Braque als een schuchtere poging tot abstractie. Het ligt dan ook voor de hand dat Van Doesburg weinig lof heeft voor de interpretatie van Henry, waarin de toeschouwer van een kubistisch werk het gebruikte 'vormenschema' weer tot ding of voorwerp reconstrueert. (Net als bij het recente, 'kaleidoscopisch-naturalistische' werk van Van der Leck, schimpt hij nog even tussen haakjes op zijn voormalige medestander.) (IV:I 2 (1921), 174-175) .

In het daaropvolgende jaar komt Van Doesburg in De Stijl expliciet op het ontwikkelingsbegrip terug, en nu niet meer alleen ten opzichte van recente bewegingen, maar in een ruimer verband, zoals Wils dat eerder al eens lapidair had gepoogd met zijn ontwikkelingsschema van de symmetrie. 'Der Wille zum Stil', de tekst van een lezing die Van Doesburg in Jena, Weimar 
en Berlijn had gegeven, presenteert een ontwikkelingsmodel dat de cultururgeschiedenis vanaf de oude Egyptenaren tot op het heden van de Nieuwe Beelding probeert te beschrijven. ${ }^{28}$

De titel van de lezing doet denken aan Nietzsches Wille zur Macht. Kennelijk las de soms nogal beïnvloedbare Van Doesburg in deze dagen Nietzsche. Diens invloed lijkt oppervlakkig, getuige een zin als de volgende:

Das Tragische in der Kunst ist der psychologiscbe Ausdruck des unvollkommenen zerrissenen Menschen, der glaubte, dass die grossen Gegensätze, welche er sich primitiv als Diesseits und Jenseits, [...] als das Gute und Böse dachte, niemals in vollständige Harmonie zu bringen warlen]. (v:2 (1922), 28)

Toch echoot Van Doesburg niet alleen boektitels. Geïnspireerd door het radicale en dynamische van Nietzsches filosofie voorziet hij de evolutie in de cultuur van het voor Nietzsche zo belangrijke, metafysisch geladen begrip 'strijd'. De drijfveer van de evolutie is 'der Wille zur Überwindung der Natur', een door Van Doesburg verzonnen explosief mengsel van Nietzsches Wille zur Macht met het verlangen van de verlichting tot volledige natuurbeheersing. Een dergelijke metafysische intuïtie maakt een meer vitale indruk dan louter discursieve, hegeliaanse noties als 'de zelfontplooiing van de geest'. ${ }^{29}$

Van Doesburg presenteert in 'Der Wille zum Stil' een wat curieus, maar voor zijn opvattingen verhelderend schema van de 'geestelijke groei van het menschelijk zijn in het Al', om de eerder geciteerde woorden van Huszár nog eens aan te halen. Het model is echter alleen te vatten wanneer men zich beperkt tot het voor de geest halen van concrete kunstwerken uit de aangegeven periodes. Het ziet er aldus uit: 


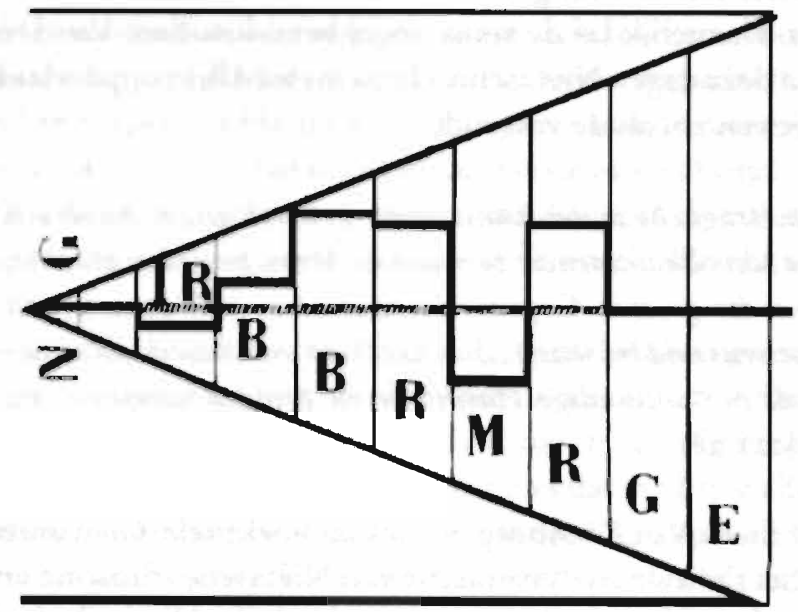

Mit den zwei wagerechten Liniciı seien die Polarität Natur (oben). -Geist (unten), das .Außerste Eine" und das "AußBerste Andere" dargestellt. Aus der allmählichen Ausgleichung dieser zwei Kräfte ergibt sich das Dreieck, welches die kulturellen Entwickelungstypen von der Zeil der Ägypier bis zur Neuzeil umfal3t. Die Buchstaben bedeuten also - von rechts nach links $E=$ Agypter. $G=$ Griechen, $R=$ Romanen, $M=$ Mittelalter. $\mathrm{R}=$ Renaissance, $\mathrm{B}=$ Barock, $\mathrm{B}=\mathrm{B}$ Biedermeier, $\mathrm{IR}=$ Idealismus-Reformation, $\mathrm{NG}=$ Neue Gestaltung. die jetzt beginnende Epoche. Die schraffierte mittlere Linie stellt das Mittel dar, die absolute Einheit der .Zweiheit" Natur-Geist. (Durchgehende Evolution.)

Op het eerste gezicht mag dit schema wat verwarrend lijken (de tijdschaal loopt naar links, NG is niet Natur / Geist maar Neue Gestaltung, i.e. Nieuwe Beelding, enzovoort), maar de bedoeling wordt met het commentaar van Van Doesburg snel duidelijk. De driehoek geeft een zich in de tijd steeds meer realiserend evenwicht aan tussen de natuurlijke pool (boven) en het geestelijke (onder). De punt van de driehoek suggereert dat de volstrekte harmonie in de synthese van het natuurlijke en het 
geestelijke met de komst van De Stijl voltooid is, hoewel Van Doesburg vlak daarvoor expliciet verkondigt: 'Nirgends und nie gibt es ein Ende. Immer geht es weiter.' (v:2 (1922), 25)

De donkere lijn geeft aan 'in welchen polaren Verhältnis sich das künstlerisch-kulturelle Leben jeder einzelnen Epoche vollzog'. In de cultuur en de kunst van de Egyptenaren (die Van Doesburg zich kennelijk als monumentaal en half abstract voorstelde) en van de Grieken is sprake van eenheid van het geestelijke en het natuurlijke, voor zover dat in dit vroege stadium van culturele evolutie mogelijk is. De Romeinen slaan in dit schema te veel naar het natuurlijke (het realistische) door, terwijl zich in de middeleeuwen weer een overmatige vergeestelijking manifesteert.

In de door Van Doesburg beschreven ontwikkeling speelt echter niet alleen deze tegenstelling tussen een meer of minder realistische weergave van de natuur, maar ook het picturale perspectief een rol. Zo haalt hij Rembrandts sterke contrast tussen licht en donker naar voren, waarin de afgebeelde, gekleurde figuren aan de schilderkunstige compositie ondergeschikt worden gemaakt. Deze lijn trekt Van Doesburg door naar de impressionisten: bij Manet zijn de contrasten tussen licht en donker inmiddels tegenstellingen tussen de kleuren zelf geworden. De volgende stap wordt dan gezet door de ook al door Mondriaan genoemde Van Gogh, waarna de natuurlijke beelding verder wordt ontrafeld door Van der Leck en Picasso.

Wanneer men nog een blik op het schema werpt, verbaast nu misschien het hoge 'natuurgehalte' van de barok, maar Van Doesburg rekent Rembrandt waarschijnlijk niet tot deze stijl. De punt van de driehoek roept meer problemen op: nergens wordt uitgelegd wat hier precies met Biedermeier bedoeld wordt en wat 'Idealismus-Reformation' is. Bij dit laatste gaat het wellicht om alle recente stromingen en kunstenaars die het 'geestelijke in de kunst' nastreven (impressionisme, futurisme, kubisme; Manet, Cézanne, Van Gogh, Picasso, Braque, Kandinsky).

In deze wonderlijke apex kiemt ten slotte ook al een oplossing voor wat Van Doesburg het tijdprobleem noemt, de moeilijk- 
heid opeenvolging af te beelden. Onder andere bij Rousseau en Van der Leck zien we hoe door herhaling van motieven het 'malerische Zeitgefühl' tot uitdrukking kan worden gebracht in een zogenaamde mechanisering van beeldvlakken. (v:2 (1922), 32)

Het mechanische, de synthese van het statische en het dynamische, is volgens Van Doesburg geëigend voor de nieuwe stijl, nu immers artistieke en technische ontwikkelingen samen beginnen te vallen. De ontwikkeling van de primitieve steenboor tot een perfect werkende machine en die van tekeningen uit de steentijd tot het elementaire kunstwerk van heden lopen namelijk niet alleen parallel, maar beginnen in elkaar op te gaan. Terwijl het handwerk en het individuele allengs meer verouderen, culmineren beide ontwikkelingen in machinale produktiemethoden en een 'mechanische esthetiek'. De komende stijl, zo verkondigt Van Doesburg op een voor zijn doen wat religieuze, of misschien eerder nietzscheaanse toon, zal een stijl zijn van verlossing en vitale rust. (v:3 (1922), 33 e.v.)

\section{Consequente doorvoering}

Inmiddels is uitvoerig gebleken hoezeer De Stijl de beoogde veranderingen in de architectuur en in de schilderkunst in termen van vooruitgang begreep, al vallen in dit verband eerder woorden als 'evolutie', '(bewustzijns)groei' en vooral 'ontwikkeling'. In de eerste plaats beriepen argumenten zich telkens op de tijdgeest, een beschouwingswijze die in het begin van de eeuw ook populair was in de academische kunstgeschiedenis.

Nu zijn geschiedinterpretaties die van de tijdgeest uitgaan, minstens even goed te verenigen met noties van terugval of met cyclische patronen. In het geval van De Stijl ging het bij het tijdgeestconcept echter steeds om een voortgaande ontwikkeling. Bij kunst, zo moppert Mondriaan in dit verband, 'spreekt men gaarne van schommelingen en wendingen' (waarmee hij tegen het gelijknamige tijdschrift schopt) ' - maar evolutie wordt gretig genegeerd'. ( $\mathrm{r}: 8$ ( $19 \mathrm{r} 8$ ), 90, noot I) Het belang van het concept van de tijdgeest lag in de historisch-metafysische dimensie 
die hiermee aan de (eigen) geschiedenis kon worden verleend. Eigenlijk, in essentie, was er een nieuwe tijd aangebroken: wie dat niet inzag, zou allengs meer in een schijnwereld leven, die onherroepelijk voorbij was, die wezenlijk had afgedaan.

Deze metafysische benadering van de geschiedenis leidde herhaaldelijk tot de veronderstelling van een noodzakelijke ontwikkeling in de kunst. Er werd dan een meer of minder expliciet beroep gedaan op ideeën die aan de evolutietheorie, aan hegeliaans erfgoed of an een positivistische geschiedopvatting ontsprongen. Deze drie soorten argumentatie, die (zoals eerder beschreven is) in de negentiende eeuw gestalte kregen, lopen in De Stijl voortdurend door elkaar, ook bij afzonderlijke medewerkers.

Dat geldt evenzeer voor de afwisseling van een idioom waarin de geleidelijke ontwikkeling voorop staat met het jargon van de breuk, een ambivalentie die telkens bij de avant-garde opduikt. Daaraan lagen dezelfde soorten argumentatie ten grondslag waarbij de breuk in evolutionaire context als 'mutatie' werd opgevat en in dialectische redeneertrant als antithese kon worden verantwoord. Een positivistische rechtvaardiging van de breukgedachte valt in De Stijl niet aan te treffen en laat zich ook moeilijk voorstellen; in een comtiaans positivisme is immers hoogstens sprake van een tijdelijke stilstand.

Ontwikkeling en vooruitgang in de kunst verschijnen in $D e$ Stijl verder herhaaldelijk als een onlosmakelijk deelproces van hetzij een universeel maatschappelijke vooruitgang (vooral bij architectuur), hetzij een nog algemenere, meer speculatieve ontwikkeling in de cultuur, een algehele 'geestelijke groei'. Omgekeerd is echter ook de avantgardistische voorhoede-idee vaak an te treffen, volgens welke De Stijl niet deel van zulke ontwikkelingen uitmaakt, maar juist vooroploopt en de weg wijst, zoals in het geval waarin Van Doesburg zich tegen het kubisme afzette.

De invloed van het hegeliaanse ontwikkelingsdenken op de theoretici van De Stijl brengt een probleem met zich mee dat Peter Bürger al eerder bij avant-gardebewegingen heeft bespeurd. ${ }^{\circ}$ Het finalisme van dit denken staat namelijk op ge- 
spannen voet met een ook in de toekomst onbegrensd voortschrijden van gewenste ontwikkelingen en tast de status van de kunst zelf aan. Dit blijkt herhaaldelijk bij De Stijl. Niet bij de architecten van het eerste uur (want architecten willen blijven bouwen, al hield Van 't Hoff ermee op), maar vooral bij in dit opzicht meer theoretisch gestemde vertegenwoordigers als Van Doesburg en Mondriaan.

De door de laatste beschreven 'consequente doorvoering' van de evolutie zou uiteindelijk ook de kunst zelf achter zich laten. In 'De realiseering van het Neo-Plasticisme in verre toekomst en in de huidige architectuur' stelde Mondriaan dat dit proces al aan de gang was. Bouwkunst werd immers 'bouwen', kunstnijverheid loste op in machinale produktie,

'Toneelkunst' wordt terzijde gedrongen door Cinema en Music-hall; 'Muziek' door dansmuziek, gram[m]ofoon, enz; 'Schilderkunst' door Cinema, fotografie, reproduktie, enz. 'Literatuur' ging uit haren aard reeds grootendeels op in 'praktisch nut' (wetenschap, journalistiek, enz.) en gaat dit steeds meer. Als 'Dichtkunst' wordt zij meer en meer belachelijk. Evenwel: ondanks alles zetten alle Kunsten zich voort en zoeken vernieuwing. Maar ook de weg tot vernieuwing is hun vernietiging. Evolueeren is breken met traditiede 'Kunst' (in traditioneelen zin) gaat reeds al meer verloren: is dat reeds in de Schilderkunst (als Neo-Plasticisme). (v:3 (1922), 4r)

Deze formulering laat nog ruimte aan het voortbestaan van een niet-traditionele kunst, een ambiguïteit die in deze context telkens terugkeert. Aan de ene kant meent Mondriaan dat de kunst haar werk gedaan heeft als de harmonie van het volledige leven bereikt is, als het 'domineeren der levenstragiek [...] ten einde' en 'het levensbeweeg zelf [...] harmonisch' is. Anderzijds laat hij hier direct op volgen dat dit niet tot verstarring leidt, omdat voortdurende 'verdieping' mogelijk blijft en voor 'schoonheid' vereist is. ( $v: 3$ (1922), 43-44)

Van Doesburg is (als altijd) radicaler. In de volgende jaargang 
- drie en een half jaar later; Van Doesburg zwemt inmiddels door zoveel Europese kunstbewegingen dat hij nauwelijks meer tijd lijkt te hebben voor een geregelde produktie van $D e$ Stijl-publiceert hij een manifest met de hegeliaanse titel: 'Het einde der kunst'. ${ }^{3}$ Het stuk ademt het anti-esthetische ideaal van de avant-garde, het verlangen de kloof tussen kunst en leven te overbruggen. De kunst is een renaissancistische uitvinding, schrijft Van Doesburg hier, die niet wezenlijk vernieuwd kan worden. Vooruitgang betreft 'de lengte van het geheele leven' en dat maakt het zo exclusief geworden verschijnsel kunst onmogelijk. Ten tweede is kunst tegenwoordig een belemmering voor 'de ontwikkeling van het reëele leven', kunst heeft het leven vergiftigd:

Briefkaarten, Postzegels, Tabakszakjes, Spoorkaartjes, Kamerpotten, Parapluies, Handdoeken, Pyama's, Stoelen, Beddekens, Zakdoeken, Dassen, alles is verkunst. Verfrisschen wij ons toch aan zulke dingen, welke geen kunst zijn. De badkamer, de badkuip, bet rijwiel, de auto, een machinekamer, een strijkijzer.

Er zijn menschen, die nog in staat zijn zulke mooie dingen zonder kunst te maken.

Dat zijn de vooruitstrevenden. (vi:9 (1925), 136)

Gezien de grote invloed die De Stijl later op vormgeving heeft gekregen, mag dit fragment wonderlijk aandoen, maar Van Doesburg hekelde natuurlijk een ander soort vormgeving, die van versiering en ornament. Merkwaardiger is echter dat hij in de jaren daarop een geheel andere opvatting over kunst in praktijk brengt. Als gezegd propageert hij dan namelijk een nieuwe stijl, het elementarisme, die hij als een nieuwe ontwikkeling, in termen van vooruitgang presenteert, als een nieuw stadium in de kunst. (vir:75/76 (1926-1927), 38-39)

$\mathrm{Al}$ met al maken de opvattingen van Van Doesburg over de 'consequente doorvoering' toch veel eerder een indruk van niet-finalistische, onbeperkte vooruitgang dan die van Mondriaan, zeker binnen de grenzen van de schilderkunst. Welis- 


\section{Steeds mooier}

waar is er in het latere werk van Mondriaan nog van een artistieke ontwikkeling sprake, maar die staat in geen verhouding tot de vergaande vernieuwing waarvan Van Doesburg getuigt. Dit perspectief werpt ook een ander licht op de verwijdering tussen Mondriaan en Van Doesburg.

Dat die niet louter ging over de toelaatbaarheid van de diagonaal en van niet-primaire kleuren is inmiddels gemeengoed. Van Doesburgs overtuiging, niet alleen als kunstenaar, ook als theoreticus en instigator van een beweging, dat een altijd verder gaande ontwikkeling en vernieuwing essentieel was, resulteerde in veranderingen die de meer beginselvast denkende en werkende Mondriaan allengs meer moeten hebben gehinderd. Voor de laatste was de Nieuwe Beelding de culminatie van een eeuwenlange ontwikkeling, een (dan wel het) eindpunt van de evolutie in de kunst.

Deze tegenstelling tussen Van Doesburg en Mondriaan speelde reeds langer en was in een op 24 juni 1919 geschreven brief van Van Doesburg aan Oud al eens onder woorden gebracht. Daarin schrijft hij naar aanleiding van een gesprek dat hij met Mondriaan had:

Ik verdedigde het begrip dat wij overgang waren, evenals Cézanne naar ons - wij weer naar iets anders. Alles is en mouvement perpétuel! Mondriaan is feitelijk dogmaticus. 32

\section{De artistieke revolutie van De Stijl}

Naast de eerste in het begin van dit hoofdstuk opgeworpen vraag is ook de tweede al grotendeels beantwoord, de vraag namelijk op welke manier De Stijl gebruik makte van vooruitgangsretoriek. Toch kan het verhelderend zijn wat nauwkeuriger stil te staan bij dit gebruik van vooruitgangsbegrippen en bij de vraag in hoeverre hier van een artistieke revolutie gesproken kan worden.

Allereerst is de in vorige hoofdstukken al aan de orde gestelde 
constructie van een eigen voorgeschiedenis van een vernieuwingsbeweging in het bovenstaande ter sprake gekomen, zowel bij architectuur als bij schilderkunst. Het voordeel van een dergelijke reconstructie is evident: de historische ontwikkelingen in de kunst krijgen zo een overtuigend logisch en noodzakelijk karakter. Wie het belang van de bepleite veranderingen niet onder ogen ziet, miskent de loop van de geschiedenis. Om nog één voorbeeld te geven: in de derde jaargang bespreekt Van Doesburg lovend een boek van Iwan Goll, die een ontwikkeling suggereert van Diderot via Cézanne naar Mallarmé. Wanneer Goll aan Picasso toekomt, citeert Van Doesburg hem instemmend als gesteld wordt dat de Franse kunst voor Europa opnieuw 'die Bahnen gebrochen [hat]. Die Linie geht über Picasso weiter...', waarna Van Doesburg Goll aldus onderbreekt:

\section{(Zeer juist! Kent Iwan Goll de werken van Piet Mondriaan niet?) naar de Nieuwe Beelding, naar Stijl. 33}

Als gezegd impliceert de constructie van een eigen voorgeschiedenis een historische structuur die van continuïteit uitgaat, wat op gespannen voet staat met een retoriek van de breuk. Een dergelijke retoriek gaat doorgaans samen met een revolutionaire terminologie, waarin een welomschreven groep de betreffende revolutie opeist en forceert.

Die terminologie is in het voorgaande al uitvoerig gekarakteriseerd, maar er moet nog een element worden uitgelicht, namelijk de verwoording van een gevoel van impasse en verwarring. Impliciet spreekt een dergelijk gevoel natuurlijk uit de reeds gesignaleerde veelheid aan theorieën (en kreten) die ter rechtvaardiging worden aangevoerd. Het wordt nog duidelijker met betrekking tot de eigen historische plaatsbepaling van De Stijl, zowel in eerder genoemd opzicht (situering in een bepaald his * torisch model), als in het voortdurende zoeken naar medestanders en vijanden in een razendsnel veranderend, onoverzichtelijk krachtenspel van vernieuwingsbewegingen. De gevoelde impasse in de kunst wordt echter ook veel directer verwoord.

Op dit gebied is Van Doesburg in zijn element. Naar aanlei- 
ding van een inaugurele rede, gehouden door de in De Stijl telkens zo gesmade R.N. Roland Holst voor de Rijksacademie van Beeldende Kunsten, schetst hij bijvoorbeeld het klimaat waarin zoiets vreselijks als diens benoeming plaats kan vinden:

Vóór de ontbinding van een kultuur intreedt, ontstaat er een, meestal kort, tijdperk van verweekelijking. Het vrouwelijk element krijgt de overhand. Het gebaar wordt theatraal. Het pathos onecht. De sentimentaliteit, het geteem, nemen vage, onbepaalde vormen aan. In de schilderkunst gaan Vorm en Kleur te gronde. Vorm vervloeit tot een grillig spel van slappe lijnen; Kleur wordt afgestemd tot graauw. En in deze vaagheid gaan zelfs de karakteristieke trekken verloren van dat tijdperk waarin deze schijnwaarden eener zelfgenoegzame en burgerlijke [k]ultuur, gebaseerd op de, den geest verlammende opeenvolging van aandoeningen, nog beceekenis badden. (I:9 (1919), 103)

Dit gaat nog even door: schmink, roof, fraude, plundering van het verleden, leentjebuur en arrogante pose zijn zo nog wat invectieven die hierop volgen.

Ook onder de architecten vallen zulke geluiden veelvuldig te beluisteren, bijvoorbeeld bij Oud in zijn al eerder aangehaalde beklag over de marxisten. Het viel te bespeuren bij Wils, die bitter vaststelde dat de inrichting van onze huizen nog dezelfde was als in 'de Lodewijk-tijd'. Of bij Van 't Hoff, die de impasse in de Nederlandse bouwkunst beschrijft; de architectuur mist node de 'evolutie, welke b.v. het moderne vervoermiddel ondergaan heeft', de techniek wordt verwaarloosd, de bouwmaterialen zijn inferieur, in de bestaande steden is vernieuwing uitgesloten, enzovoort. (I:5 (1918), 57-59)

In plaats van de talloze mogelijkheden te benutten die nieuwe technieken en procédés met zich meebrengen, heerst desoriëntatie en lethargie alom. De Stijl constateert verwarring en stilstand, zo niet verval. Ze constateert dit soms bijna triomfantelijk, want de impasse is de springplank naar het nieuwe. 'Er is voor Europa geen uitkomst meer', heet het in 'Manifest III. Tot een nieuwe wereldbeelding': 


\section{Vernieuwing in schilderkunst en architectuur: De Stijl}

Wij kijken rustig toe. Waren wij er al toe in staat, we zouden niet willen belpen. Wij willen het leven van deze oude prostituéle] niet verlengen.

Reeds is in ons een nieuw Europa begonnen. (Iv:8 (1921), 126)

Dit is het revolutionaire jargon waarin het pathos van het Communistisch Manifest nagalmt, een geluid dat in veel avantgardistische pamfletten opklinkt. Maar volstrekt holle leuzen waren het niet bij De Stijl, want althans binnen de schilderkunst kon Van Doesburg vrij goed uitleggen waar de artistieke revolutie uit bestond. Deze school in de kubistische problematiek hoe natuurlijke beelding diende te worden omgezet in het 'primaire beeldingselement' van het vlak. Deze pogingen karakteriseert hij als 'het revolutionaire stadium, het kritieke ogenblik bij uitnemendheid in de schilderkunst'. (IV: 12 (1921), I75)

Het bezigen van een revolutionaire terminologie en het standvastig geloof in de realisering van nieuwe waarden kan tijdens een artistieke omwenteling bijna alleen maar plaatsvinden binnen een min of meer gesloten gemeenschap. Nu was de sociale coherentie van De Stijl niet buitensporig groot-de meeste contacten liepen aanvankelijk via Van Doesburg en het tijdschrift zelf - maar strategische groepsvorming treedt toch veelvuldig op. De Stijl wilde zich laten gelden als de exclusieve koploper van ontwikkeling in de kunst, waar ook ter wereld. Ze probeerde dan ook in binnen- en buitenland steun te verwerven en profileerde zich niet alleen door zich tegen een duidelijk gevestigde traditie af te zetten, maar ook door concurrerende vernieuwingsbewegingen naar het leven te staan.

Dat bleek al uit de agressieve toon jegens de Amsterdamse School en het tijdschrift Wendingen.34 En het bleek uit de manier waarop Van Doesburg zich na enige tijd tegen het kubisme en het futurisme begon af te zetten, en tegen (zoals boven geciteerd werd) de bedrieglijke namaak van het quasi- of pseudo-nieuwe. Eigenlijk werd dan impliciet geschermd met de genoemde argumentatie van het werkelijk moderne. Zo gaf Mondriaan in 'De huif naar den wind' af op die avantgardisten 
die een beetje meededen zonder de radicale consequenties uit de nieuwe tijd te trekken, op 'de verraderlijke houding der voorgangers van het nieuwe'. (vi:6/7 (1924), 87)

Mondriaan verzette zich hierin onder meer tegen een groep Parijse kubisten als Picasso en Severini, die inmiddels weer figuratief werk maakten. Ook Van Doesburg roerde zich in deze kwestie. In de vijfde jaargang bespreekt hij een aantal buitenlandse tijdschriften; in deze 'zgn: “nieuwe kunst"-tijdschriften' treft hij 'belangrijke, reactionaire artikelen' aan. Ooit pleitbezorgers van abstractie, hebben die geschriften zich nu aan 'de kunsthandel' vitgeleverd en grijpen ze terug op 'naturalisme'. 35 Nadat Van Doesburg geen voet aan de grond heeft kunnen krijgen bij het Bauhaus en daarom elke samenwerking met De Stijl onmogelijk is gebleken, wordt ook dit buiten zijn groep vallende instituut ontmaskerd:

Zooals de kerk de parodie is van het Christendom, zoo is het Bauhaus van Gropius in Weimar[,] de parodie der nieuwe beelding. [...] Gebrek aan en ontkenning van een fundamenteel beeldingsbesef deed [...] de nienwe kunstuitdrukking in een soort ultrabarok ontaarden. (v:s (1922), 72)

Fel wordt Van Doesburg als het 'verraad' binnen eigen gelederen plaatsvindt. Eerder is al gemeld hoe hij op de handelsreiziger Oud afgaf en naar Van der Leck schopte. Woedend wordt hij ook wanneer Wils en Huszár aan een ander tijdschrift (Levende Kunst) meewerken, of wanneer hij een paar jaar later, na het fiasco in Weimar, ontdekt dat Rietveld genoemd wordt als medewerker aan een tentoonstelling van het Bauhaus. ${ }^{6}$ Illustratief is ten slotte zijn reactie op Huib Hoste, die over architectuur in De Stijl had gepubliceerd, maar door Van Doesburg werd betrapt op onzuiverheid in de leer. Hoste kwam namelijk in dezelfde maand met een lovend artikel over werk van de beeldend kunstenaar Henriëtte Willebeek Le Mair in de Nienwe Amsterdammer (29-7-1918). Misbruik van de De Stijl-terminologie en waardering voor 'soepele' gebogen lijnen vonden in de ogen van Van Doesburg geen genade. Men kon geen twee heren dienen, 
liet hij later in een reactie op Hostes verweer nog eens weten: barok of modern, 'maar s.v.p. geen modern-barok'.37

Bij deze polarisatie en groepsvorming van De Stijl hoort ook de constructie van een eigen recente geschiedenis van de beweging, in overeenstemming met de gecreëerde voorgeschiedenis en zo overzichtelijk mogelijk gepresenteerd. Vooral Van Doesburg is dit een zorg. Het jubileumnummer IO JAREN STIIL is een goed voorbeeld van een overzicht waarin een kunstenaar als historicus van de eigen tijd optreedt. (Wel drukte Van Doesburg een sterk persoonlijk stempel op dit nummer. Oud schreef hem dat het er alleen nog maar aan ontbrak dat Van Doesburg ook de eerste transatlantische vlucht en het eind van de Eerste Wereldoorlog voor zich opeiste. ${ }^{3}$ )

Veelzeggend is het in dit nummer als objectief gepresenteerde succes van De Stijl, met een groot schema van 'principieele medewerkers' gedurende de afgelopen tien jaar en een diagram, waarin de 'Invloedsverhouding van de Stijlbeweging in het Buitenland sedert 1917 ' is opgetekend. (Bedoeld wordt waarschijnlijk het aantal jaren, dat Van Doesburg in een bepaald land contacten had; inmiddels was dat volgens zijn eigen berekening in 25 landen het geval.) Verder is er een grafiekje afgebeeld dat de 'Lijn van ontwikkeling van 1917 tot 1927 ' weergeeft. Op de y-as staan de jaartallen, de x-as blijft leeg. Hoe dan ook, de lijn stijgt enorm; iedereen kan zien dat hier van 'ontwikkeling' sprake is. (vir:79/84 (1927), 59-62)

De historiserende blik waarmee Van Doesburg over zijn eigen schouder meekeek - het ambivalente bewustzijn, speler en toeschouwer tegelijk te zijn, inwonend en op doorreis, om de eerder aangehaalde woorden van Susan Sontag nog eens te memoreren - leverde soms wel enige problemen op. Dat blijkt bij het ontwerp dat Oud in 1917 van 'De Vonk' maakte, een vakantiehuis voor arbeiderskinderen, dat in 1919 werd voltooid. (Van Doesburg ontwierp het interieur van de hal, het trappehuis en de bovenhal.) 'De Vonk' had een nogal traditioneel aanzien, met schuine daken, baksteen en dakpannen. Van Doesburg zat ermee in zijn maag en suggereerde Oud een maand nadat het gebouw geopend was, zijn ontwerp te antedateren naar 1916 en 
eraan toe te voegen dat hij er zelf niet meer achter stond, 'evenmin als Mondriaan en Van Doesburg het nog met werk uit dien tijd geheel eens zullen zijn',39 Om vergelijkbare redenen retoucheerde Van Doesburg een interieurontwerp voor Bart de Ligt dat hij in 1919 gemaakt had. Het verscheen zwart-wit in 1920 in De Stijl (nI:12), met vermelding van andere kleuren, en werd enkele jaren later elders met primaire kleuren afgedrukt, omdat dit beter was voor de beeldvorming van De Stijl.4 De geschiedenis van de beweging diende kennelijk een ondubbelzinnig en ordentelijk karakter te vertonen: de Vooruitgang marcheert niet in mottige pakken.

\section{De Stijl en het nageslacht}

$\mathrm{Al}$ met al heeft De Stijl haar uiterste best gedaan zichzelf een belangrijke plaats in de geschiedenis toe te kennen, zoveel mag inmiddels duidelijk zijn. Maar kreeg ze die plaats uiteindelijk ook? Als ze al dat brandpunt van veelomvattende vernieuwingen is, zoals Friedman beweert, hoe werd ze dat dan? Beschrijft de kunstgeschiedenis in haar nog altijd bestaande historische overzichten de vernieuwing van De Stijl als diezelfde stap vooruit die de medewerkers van deze beweging meenden te hebben gezet?

Dat laatste is niet zonder meer het geval en daarmee dient ook Friedmans eerbetoon wat te worden gerelativeerd. In de meeste kunsthistorische overzichten wordt aan Mondriaan en aan Rietveld wel een voorname plaats toegekend, maar dan steeds in een bredere, internationale context die voor DeStijl zelf destijds ondergeschikt was aan het eigen belang. Waar De Stijl zichzelf als brandpunt zag en de buitenlandse vernieuwing als een, al dan niet correcte, afspiegeling daarvan, is in de kunsthistorische canon precies het omgekeerde gebeurd.

In het uit 1936 stammende en sindsdien vele malen herdrukte (en nog herziene) historische overzicht van architectuur en vormgeving, Nikolaus Pevsners Pioneers of Modern Design, loopt die stroom 'from William Morris to Walter Gropius', 
zoals de ondertitel veelzeggend luidt. Gropius representeert in dit tegenwoordig veel voorkomende perspectief een schakel die de culminatie van een ontwikkeling is en tegelijkertijd de aanvang van het twintigste-eeuwse bouwen, kortom: een brandpunt van veelomvattende vernieuwingen dat de architectuur van De Stijl tot krabbels in de marge reduceert. Van Doesburg heeft, zo valt achteraf met enig sarcasme vast te stellen, in zijn vaak bewust strategisch gevoerde gevecht om een plaats in de geschiedenis op het verkeerde paard gewed door het tijdens zijn verblijf in Weimar niet met Gropius op een akkoordje te gooien. Zo werd het Rietveld-Schröderhuis een min of meer geïsoleerd gepresenteerde illustratie bij de internationale stroom van architectonische vernieuwing.

Nu gaat Pioneers of Modern Design niet verder dan het begin van de Eerste Wereldoorlog (toen er al enkele projecten van Gropius waren gerealiseerd en nog niets van De Stijl), maar ook Pevsners veel later verschenen, gezaghebbende $A$ History of Building Types en An Outline of European Architecture besteden hoegenaamd geen aandacht aan De Stijl, evenmin als de in een aantal talen verschenen architectuurgeschiedenis van Leonardo Benevolo, Storia dell'architettura moderna, die toch de nodige ruimte wijdt aan de Nederlandse bouwkunst van toen.41

De marginale plaats van De Stijl in de architectuurgeschiedenis is voor een deel verklaarbaar door het wisselvallige karakter van de beweging; het snelle vertrek van Van 't Hoff, Wils, Huszár en met name Oud; daarnaast het andersoortige karakter van Van Doesburgs latere werk (inrichting van de Aubette in Straatsburg met Hans Arp en Sophie Täuber Arp). Vooral het geringe aantal gerealiseerde projecten heeft veel afbreuk gedaan aan het belang en de reputatie van De Stijl; werkelijk gebouwde voorbeelden blijken meestal van veel meer invloed dan tekeningen en teksten.

Bij dit alles kwam nog dat er in de loop van de jaren twintig in de Nederlandse architectuur een enigszins verwante andere stroming ontstond, die wel bouwde, minder dogmatisch was en meer internationale contacten had. Hiertoe behoorden onder andere Stam, Merkelbach, Duiker en niet te vergeten: Oud. Na 
een samengaan van de functionalistische groep De 8 met de architecten van De Opbouw in 1928 maakte deze Nieuwe Zakelijkheid deel uit van de zogenaamde Internationale Stijl, een wereldwijd functionalisme dat het karakter van de architectuur vergaand en langdurig zou bepalen.

De ideeën van De Stijl hebben volgens kunsthistorici echter wel invloed gehad op deze ontwikkelingen, niet alleen bij $\mathrm{Ne}$ derlandse architecten; indirect ook in het buitenland, bij Le Corbusier en, niet in de laatste plaats, bij het Bauhaus (Gropius, Mies van der Rohe en anderen). Maar deze invloed is diffuus en vaak indirect.42 De Stijl als beweging lijkt in de geschiedenis van een voortschrijdende bouwkunst uit de boot te zijn gevallen. Niettemin is de canon van de twintigste-eeuwse architectuurgeschiedenis nog flink aan verandering onderhevig, waarbij het functionalisme aan invloed inboet. Die herschikking van het verleden heeft ook consequenties voor De Stijl. Zo wijdt Framptons Modern Architecture een hoofdstuk aan de Nieuwe Beelding en inmiddels wekt Overy geen erg retorische indruk meer als hij beweert, dat De Stijl een verbinding vormt tussen

pre-1914 avant-garde of Cubism and Futurism and the post-1918 modernism of [...] International Style architecture. 43

Maar omdat een snelle acceptatie van De Stijl destijds is uitgebleven, in tegenstelling tot wat bij de Beweging van Vijftig in het vorige hoofdstuk viel te bespeuren, zal een opwaardering van de De Stijl-architectuur denkelijk moeizaam verlopen.

Dat geldt a fortiori voor de schilderkunst, waarin zich een dergelijke verschuiving van de canon ten aanzien van De Stijl in veel mindere mate voordoet. Wel is de internationale belangstelling groter geworden. De tentoonstellingen uit 1982 en de daarmee samenhangende publikaties zijn daar zowel een uiting als een oorzaak van.

De meest gebruikte overzichten van de kunstgeschiedenis kennen alle een belangrijke plaats aan Mondriaan toe, maar 


\section{Vernieuwing in schilderkunst en architectuur: De Stijl}

weer evenmin aan De Stijl als beweging.44 Mondriaans positie hangt ongetwijfeld samen met de snelle Amerikaanse receptie van zijn werk - de beeldende kunst uit de Verenigde Staten werd na de Tweede Wereldoorlog immers toonaangevend - hoewel het vreemd zou zijn om bij zo'n observatie geheel aan de intrinsieke kwaliteiten van dat werk voorbij te gaan en aan de extreme indruk die het in zijn eigen tijd moet hebben gemaakt. Schilders als Van der Leck, Huszár, Van Doesburg en Cesar Domela nemen in handboeken en musea een zeer bescheiden plaats in, in het kielzog van het slagschip Mondriaan.

Iets anders ligt het bij de kunsthistorische overzichten van de negentiende en twintigste eeuw, die vanaf de jaren vijftig beginnen te verschijnen. In boeken als die van Haftmann, Lynton en Arnason gaat De Stijl, als beweging met een programma, een meer prominente rol spelen, en niet alleen omdat deze boeken relatief meer ruimte hebben voor details. 45

Wie in termen van verworvenheden of van bijdragen aan de geschiedenis tegen een dergelijke situering aan wil kijken - en dat is wat overzichten in de kunstgeschiedenis nog altijd doen en wat men nu eenmaal van de ordening van het verleden verlangt - zal de plaats van Mondriaan en van De Stijl primair in de internationale context moeten zien van het ontstaan van de abstracte kunst tussen 1905 en 1920. Dan valt al snel op dat zulke uiteenlopende kunstenaars als Kandinsky, Picabia, Braque, Picasso, Gris, Léger, Villon, Malevitch en Duchamp vóór de eerste abstracte werken van De Stijl al stuk voor stuk afscheid hebben genomen, zij het vaak tijdelijk, van wat bij Mondriaan en de zijnen natuurlijke beelding heet. Uiteraard blijven de onderlinge verschillen immens, zeker achteraf, omdat we nu het latere werk van deze schilders kennen. Maar ook in de jaren twintig waren die verschillen al heel duidelijk. Kandinsky's aan het expressionisme verwante, gevoelsmatige gedrevenheid staat lijnrecht tegenover de banvloek die De Stijl over de waarde van het gevoel uitspreekt. Het handhaven van een zeker mimetisch gehalte in het werk van Picasso en Léger heeft weinig van doen met de Nieuwe Beelding, waarin elke directe verwijzing naar het 'natuurlijke' taboe is. En de conceptuele revolutie die Mar- 
cel Duchamp na zijn aanvankelijk kubistische begin teweegbracht, is van een volstrekt andere aard dan het streven naar het 'geestelijke' van De Stijl.

Hoe fascinerend het gegeven ook blijft dat zoveel kunstenaars in een zo korte tijd, maar grotendeels onafhankelijk van elkaar, een achteraf bezien zo samenhangende omwenteling tot stand brachten, de verschillen waren en blijven toch enorm. En die verschillen zijn hier interessanter dan de overeenkomsten, want dat De Stijl bijdroeg aan deze omwenteling is een weinig opzienbarende constatering - de vraag is hoe en waarin precies. Dan is het antwoord van Jaffé niet bevredigend. Zijn in het begin van dit hoofdstuk al gememoreerde mening dat De Stijl een leidraad voor de mensheid kan zijn, ligt te dicht tegen het perspectief van De Stijl zelf aan. Jaffé ziet de inspanningen van de medewerkers van De Stijl als dezelfde stap vooruit als zij zelf destijds meenden te hebben gezet. Hij heeft een even baanbrekend als enthousiasmerend overzicht van het gedachtengoed en het artistieke credo van De Stijl geschreven, maar identificeerde zich er zodanig mee dat hij haar programma en werk in de laatste bladzijden van zijn boek kenschetst als een (in 1956) nog altijd wezenlijk appel voor een betere toekomst van de mens. ${ }^{46}$

Vrijwel alle latere monografieën en geschriften over De Stijl en haar protagonisten zijn veel afstandelijker dan de benadering van Jaffé. De vraag naar het belang van de vernieuwing van De Stijl komt eigenlijk nauwelijks meer aan bod. De kunsthistorische literatuur richt zich langzamerhand uitsluitend op lokale beschrijving en op detailproblemen bij de interpretatie van de beweging.

Waarin zou dan, om die hachelijke vraag desondanks nog eens te herhalen, de vooruitgang van De Stijl moeten schuilen? Allereerst heeft het werk van de Nieuwe Beelding onze manier van waarnemen beïnloed, en daarmee onze waarnemingsschema's (en dus onze kennis) verrijkt. De nieuwe technieken en procédés: monumentaal werk zonder diepte, primaire kleuren, orthogonale principes, een nieuwe vorm van harmonie met vermijding van symmetrie, kortom de geheel andere beeldtaal van De Stijl is een bijdrage aan een rijker geschakeerde waarneming 
en aan een groter aantal artistieke mogelijkheden. Deze beeldtaal, die afstand heeft genomen van het uitbeelden of afbeelden van de (of: een) werkelijkheid dan wel van gevoelens en stemmingen, maakt ruimtelijke verhoudingen en verwijzingen op een gearticuleerde manier, dus als verhouding en verwijzing, zichtbaar.

Net als bij de architectuur kan de artistieke bijdrage van De Stijl worden geillustreerd met behulp van de invloed die zij op beeldende kunstenaars heeft gehad. Janson wijst bijvoorbeeld op een verband tussen het werk van Mondriaan en dat van Roy Lichtenstein, en op Mondriaans betekenis voor Op Art; LucieSmith op diens betekenis voor Kenneth Noland, J.R. Soto en David Smith. ${ }^{47}$ Martin Friedman gaat in 'Echoes of De Stijl' uitvoeriger in op de invloed van met name Rietveld op Donald Judd en op Sol Le Witt; verder bespreekt hij de doorwerking van De Stijl (vooral Mondriaan) op Frank Stella, Jan Dibbets en verschillende Pop Art-kunstenaars als Segal en Lichtenstein. $4^{8}$ Ook kan een minder bekende beweging als die rond Joost Baljeu en het tijdschrift Structure (1958-1964) worden genoemd, die expliciet op het werk van De Stijl voortbouwden.

Dergelijke verbanden worden vaker gelegd. Zo is het werk van Barnett Newman moeilijk voor te stellen zonder een voorafgaande traditie waarin Mondriaan een rol speelt - al is die rol ten dele een negatieve omdat Newman zich juist tegen hem afzette, bijvoorbeeld in zijn Who's afraid of red, yellow and blue? Bij zo'n ambivalentie kan men verschillend te werk gaan. Ten eerste biografisch en sociologisch, door uit te zoeken waar en wanneer Newman Mondriaans werk leerde kennen, of hij zich daarover heeft uitgelaten, of hij hem, en eventucel andere verwante schilders, bewonderde, etcetera. Op die manier krijgen de speculatieve verbanden van kunsthistorici soms een discutabel karakter. Was Edward Hopper bijvoorbeeld bij het schilderen van zijn beroemde Early Sunday Morning 'not unaware of Mondrian', zoals Janson stelt? Het schilderij is van 1930 en wie weet dat Hopper na I 910 niet meer in Europa is geweest (en daar diep onder de indruk van de impressionisten was), wordt argwanend. Weliswaar is niet zomaar uit te sluiten dat hij werk 
van Mondriaan, of reprodukties ervan, onder ogen heeft gekregen, maar later bleek in elk geval dat Hopper niets moest hebben van mensen die de abstracte kwaliteiten in zijn werk bewierookten. Toen een vriend hem vertelde dat hij in een lezing zijn werk met dat van Mondriaan had vergeleken, zei hij: 'You kill me.' 49

Toch leidt een slechts empirisch-historische en sociologische kijk op de kunstgeschiedenis snel tot een historisme, waarin elk groter verband wordt geschuwd. De museumdirecteur, het publiek, de kunstenaar, allen hebben voortdurend ook de meer of minder verborgen behoefte aan een andere, meer inhoudelijke benadering, aan een canon met een samenhangende geschiedenis, en dat impliceert onvermijdelijk het aanbrengen van bepaalde ontwikkelingen en waardeoordelen. Wanneer een uitspraak als het bovenvermelde citaat van Overy speculatief is, dan is het daarom nog niet meteen verwerpelijk. Zo mag ook Jaffés overzicht van De Stijl gedateerd zijn in zijn ideologische identificatie, maar zijn poging om De Stijl een plaats te geven in de geschiedenis is daarmee niet gediskwalificeerd, hoezeer de meer recente kunstgeschiedenis (en andere geschiedenis) ook een voorkeur voor kleine, afgebakende momenten en details blijkt te hebben.

Wie zich Clement Greenbergs eerder in dit boek genoemde, naoorlogse kritiek op Picasso herinnert, waarmee hij Picasso het achterwege laten van totale abstractie verweet, en wie zich de in de jaren vijftig in Amerika gevoerde discussies over het platte vlak voor de geest haalt, kan De Stijl moeilijk meer over het hoofd zien.

We zijn niet naief genoeg om nog in de tijdgeest te geloven, hoe hardnekkig die ook rond blijft spoken, zoals Gombrich herhaaldelijk heeft laten zien.50 Maar in het eerste hoofdstuk bleek dat het bijna even naïef en onvruchtbaar is om grote verbanden in de geschiedenis te ontkennen. Iedereen beoordeelt het verleden met zulke interpretaties. Wölfflins beroemd geworden uitspraak over de geschiedenis in het begin van de Kunstgeschichtliche Grundbegriffe gaat ondanks het tijdgeestgehalte in deze zin nog altijd op: 
Vernieuwing in schilderkunst en architectuur: De Stijl

Niet alles is te allen tijde mogelijk en bepaalde ideeën kunnen pas in bepaalde stadia van ontwikkeling geconcipieerd worden. 51

Zo'n constatering laat zien dat over vooruitgang in de kunst nog niet het laatste woord gesproken is. 


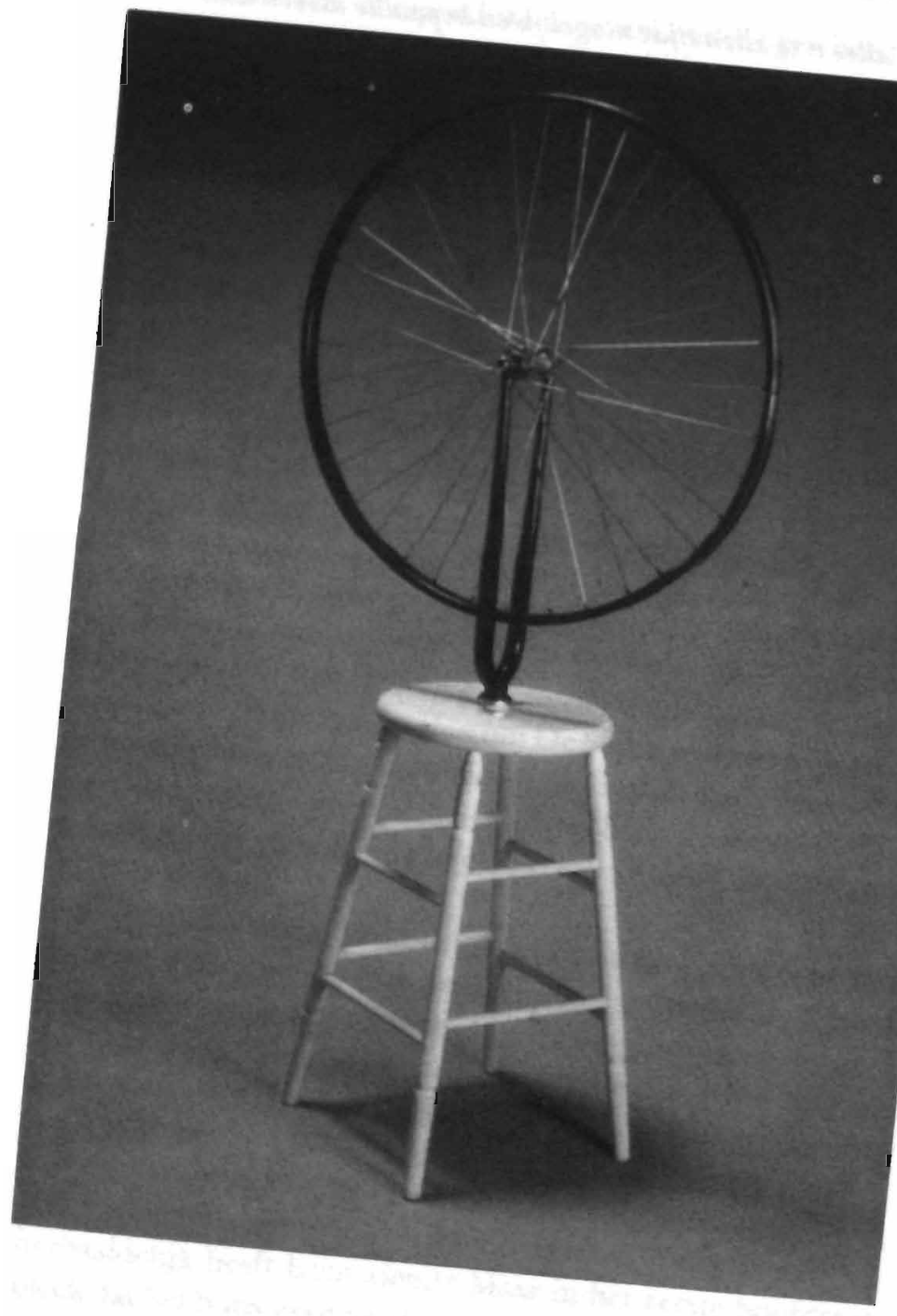

Marcel Duchamp, 'Fietswiel' (I9I 3 ) 


\section{Het einde van de kunst}

\section{De cake-walk in bet beden}

\section{De laatste hoofdstukken beschreven hoe twee bewegingen in de}

kunst, namelijk De Stijl en de Beweging van Vijftig, zich van vooruitgangsbegrippen bedienden en de door hen gepropageerde en ook gerealiseerde veranderingen zelf als vooruitgang hebben begrepen. Het daaraan voorafgaande hoofdstuk, 'Over het maken van revolutie', deed een verklaring aan de hand voor de grote rol die dergelijke begrippen konden spelen. Die verklaring maakte gebruik van Thomas S. Kuhns model voor verandering in de wetenschap, een model dat veel aandacht besteedt aan het revolutionaire karakter van overgangsfasen, en dat bovendien, in tegenstelling tot eerdere verklaringsmodellen, een aantal externe factoren verdisconteert.

Het model bleek in verschillende opzichten licht te werpen op de manier waarop veranderingen in de kunst van de laatste eeuwen gestalte kregen. Zo viel op dat bij het ontstaan van de Beweging van Vijftig en in de beginjaren van De Stijl een gevoel van impasse en onbehagen heerste. Deeze onvrede met de statusquo van de poëzie respectievelijk de beeldende kunst en architectuur vertoonde overeenkomsten met wat Kuhn beschrijft als een algemeen ervaren anomalie in de wetenschappen. Bij beide hierboven bestudeerde stromingen deed zich verder een reeks nieuwe technieken en procédés voor en in beide gevallen werden, analoog aan wat Kuhn voor wetenschap beweert, de belangrijkste veranderingen in gang gezet door jongeren of door relatieve buitenstaanders. Ook het element van een radicale omslag, door Kuhn treffend gekarakteriseerd als een Gestaltswitch, valt bij de Vijftigers en bij De Stijl te constateren. Beide groepen vernieuwingsgezinden werden in eerste instantie met 
onbegrip en geringschatting bejegend, omdat zowel hun belevingswereld als hun taal - respectievelijk beeldtaal - te zeer van de (Nederlandse) traditie en context verschilden.

De term Gestalt-switch duidt op het revolutionaire gehalte van een verandering en is een geschikte metafoor om de complexe radicaliteit van veranderingen in de kunst te illustreren. Met een ander vocabulaire en een andere zienswijze verandert de wereld. Zulke omslagen manifesteren zich in de geschiedenis van de avant-garde steeds vaker: telkens ontstaat een nieuwe stroming of beweging. De geschiedenis van de kunsten krijgt zo het karakter van een grote stroomversnelling. De radicale variant van de avant-garde met haar idioom van de breuk wordt daarom geleidelijk minder een variant. Op den duur loopt de avant-garde uit op een permanente revolutie, waarbij cesuren nauwelijks meer vallen aan te wijzen. De periodes waarin een bepaald artistiek normensysteem overheerst (de pendant van Kuhns 'normal science') worden allengs korter om uiteindelijk op te lossen in een ononderbroken revolutionaire toestand die in de loop van deze eeuw in vele kunsten al herhaaldelijk als een 'crisis' aan de kaak is gesteld. Zo'n crisis is te karakteriseren als een opeenhoping van Gestalt-switches, waarin iedereen die een ogenblik verzuimt te bewegen onherroepelijk op het verkeerde been staat, als in een cake-walk.

Naarmate breuken met het verleden zich vaker voordoen worden beschouwingen over ontwikkeling en vooruitgang problematischer, en daarmee de rol en de plaats van de avantgarde in de geschiedenis, zoals aan het eind van het derde hoofdstuk werd beschreven. Dit is een van de redenen waarom in dit boek tot nu toe niet verder werd gekeken dan de historische avant-garde. Filosofen en historici van het denken en van de kunsten hebben meestal grote moeite met het heden, waarin nog nauwelijks orde valt aan te brengen. Toch ligt het in de bedoeling om in deze laatste twee hoofdstukken op het gladde ijs van een nog nauwelijks gestold verleden vol wakken van vandaag enkele baantjes te trekken. Het afscheid van Vooruitgang tijdens de postmoderne ontluistering van 'de grote verhalen', het telkens gesignaleerde - en soms zelfs gecelebreerde - gevoel 
van een crisis in de verschillende eigentijdse kunsten, de volslagen begripsverwarring in het denken over kunst ten gevolge van een al te vrijblijvende pluriformiteit, onze complexe verhouding tegenover een ontzagwekkend omvangrijk verleden, dat ons bijna dood-inspireert, de snelle verdamping van ideologie en idealisme in de huidige westerse cultuur, dit alles noopt tot wat in levensbeschouwelijke termen al snel een berbezinning zou heten op de verhouding van heden, verleden en toekomst in de diverse kunsten. Dit hoofdstuk zal zich daartoe richten op de overal opduikende idee van het einde van de kunst en het realiteitsgehalte van dergelijke weinig heilbrengende gedachten. Daarna krijgt de overblijvende scepsis jegens vooruitgang aandacht. Het slothoofdstuk zal vervolgens proberen een antwoord te formuleren op al die apocalyptische waarschuwingen aan het adres van de huidige kunsten.

\section{Apotheose der avant-garde: bet einde van de kunst}

De avant-garde is voorbij. Er zijn weinig toonaangevende kunstenaars en professionele kunstbeschouwers die dit nog ontkennen. Niet dat de resultaten hebben afgedaan, maar we kijken naar het werk van Kandinsky of Bart van der Leck zoals naar dat van Rembrandt of Poussin, we lezen Lucebert of Joyce niet principieel anders dan P.C. Hooft of Cervantes, we luisteren met eenzelfde instelling naar Ligeti of Webern als naar Josquin des Prez en Carl Philipp Emanuel Bach, we kijken met dezelfde ogen naar de gotische kathedralen als naar de bouwwerken van Frank Lloyd Wright. In dit opzicht zijn het pluralisme en de chronologische willekeur ten opzichte van het verleden, deze grondtrekken van het postmodernisme, een gegeven, of men dat nu betreurt of niet.

De avant-garde is, om het eerder aangehaalde woord van Gerrit Kouwenaar te variëren, mooi dood of lelijk dood, maar dood, geschiedenis. Of zoals Robert Hughes dit in 1980 pregnant samenvatte in 'The future that was': 
Picasso is no longer a contemporary, or a father figure; he is a remote ancestor, who can inspire admiration but no opposition. The age of the New, like that of Pericles, has entered history. ${ }^{\mathrm{I}}$

Dit einde van de avant-garde is merkwaardig genoeg nauwelijks te wijten aan de eerder beschreven paradox, namelijk dat ze de kunst in het leven wilde doen opgaan en zo (in hegeliaanse zin) op wilde heffen. Want hoezeer deze paradox ook de kern van het esthetische programma van de avant-garde heeft uitgemaakt, ze kon er langdurig en succesvol mee bestaan. De avantgarde sneefde eerder om andere redenen.

Allereerst is de opkomst van de historische avant-garde onlosmakelijk verbonden met een versnelling in het tijdsbewustzijn van de westerse cultuur. De idee dat ontwikkelingen steeds sneller gaan hangt sterk met vooruitgangsnoties samen. De avantgardistische praktijk is hiervan welhaast een voorbeeld in reincultuur, in zoverre ze tenminste niet zelf de toon voor die versnelde tijdsbeleving heeft gezet. De avant-garde beschouwde het heden als culminatie van het verleden en als steeds dringender opdracht voor de toekomst. Wanneer echter stromingen elkaar in toenemend tempo opvolgen en belangwekkende gebeurtenissen telkens dichter bij elkaar komen te liggen, wordt deze tijdsbeleving op den duur ondermijnd. Hoe hoog is een hoogtepunt vanwaar men een ogenblik later al weer opkijkt naar nieuwe pieken? De avant-garde bleek geleidelijk aan een huis op drijfzand gebouwd, een probleem dat sommigen al in een vroeg stadium herkenden, zoals de eerder genoemde kunsthistoricus Tietze, die schilderijen tot zijn ontsteltenis zag verouderen nog voordat ze droog waren.

De versnelling in het historisch besef is recent door Susan Sontag aan de orde gesteld en bekritiseerd. In Tradities van het niewwe wijst zij erop dat de tijd in steeds kortere periodes wordt gemeten en beleefd. Was eerst nog de geschiedenis een reeks van meer of minder lange tijdperken, vaak aan een bepaalde heerschappij verbonden, vanaf de Franse Revolutie begint men de tijd in eeuwen in te delen. Vervolgens manifesteert zich aan het 
eind van de negentiende eeuw het generatiebegrip, waarna sinds de jaren zestig - zoals deze benaming zelf al illustreert hoofdzakelijk in decennia wordt gedacht. Ook met terugwerkende kracht: in de jaren vijftig bestonden de jaren vijftig nog niet. ${ }^{2}$ (Deze observatie wordt niet gelogenstraft door het feit dat de Beweging van Vijftig zichzelf als zodanig bestempelt. Hier is sprake van een generatie, want de Vijftigers bleven ook na de jaren vijftig onder deze benaming actief en invloedrijk. Het is hetzelfde generatiebegrip als dat van de Tachtigers of als dat van de Generatie van '98 in Spanje.)

In deze ontwikkeling krijgt het denken over de verhouding tussen verleden, heden en toekomst het buitengewoon verwarrende karakter dat aan het slot van het hoofdstuk 'Over het maken van revolutie' al werd geschetst. 'Onze kunstverzamelingen, onze bloemlezingen van gedichten en onze bibliotheken,' schreef Octavio Paz inmiddels twintig jaar geleden,

lopen over van stijlen, bewegingen, schilderijen, beeldbouwwerken, romans en gedichten die vroegtijdig verouderd zijn.

Een dubbele, duizelingwekkende sensatie: wat zojuist gebeurd is behoort reeds tot de wereld van het oneindig verre en tegelijkertijd is de oudheid van duizenden jaren ber oneindig dichtbij... Men kan uit dit alles de conclusie trekken dat de moderne traditie en de tegenstrijdige ideeën en beelden die deze uitdrukking oproept, niet[s] anders zijn dan de consequentie van een nog verwarrender fenomeen: het moderne tijdperk is dat van de versnelling van de histo-. rische tijd. Natuurlijk zeg ik niet dat de jaren en de dagen tegenwoordig sneller omgaan, maar dat er meer in gebeurt. Ergebeurt meer en alles gebeurt bijna tegelijkertijd, niet bet ene na het andere, maar tegelijkertijd. Versnelling is versmelting: alle tijden en alle ruimten vloeien samen in één bier en één $n u .{ }^{3}$

Dat het in deze bijna apocalyptisch aandoende verwarring nauwelijks meer mogelijk is om recente ontwikkelingen in de kunst 
in termen van vooruitgang te bespreken, werd eerder al met de in het vierde hoofdstuk aangehaalde constatering van $\mathrm{Hans} \mathrm{Bel}-$ ting geillustreerd, die vaststelde dat de (beeldende) kunst van tegenwoordig het verleden reflecteert zonder het voort te zetten en dat ook de kunstgeschiedenis er niet meer in slaagt een model van vooruitgang te handhaven.4 Voor zover de huidige kunsten en beschouwingen daarover zich nog met vooruitgangsnoties inlaten, is dat in de eerste plaats destructief. Men ervaart dan de noodzaak met het verleden te breken en een nieuwe richting in te slaan. Deze revolutionaire gezindheid laat geen ruimte meer aan de continuiteit en lineariteit die door vooruitgangsbegrippen worden verondersteld. Want waar voortdurend gebroken wordt, is geen richting of voortgang meer te bespeuren. In het beste geval heerst daar een levendige pluriformiteit, een gelijktijdigheid van het radicaal-verschillende, zoals dat bij Bürger heette.s Die formulering gaat, al dan niet bewust, verder dan de gelijktijdigheid van het ongelijktijdige, die zich volgens Koselleck sinds het eind van de achtriende eeuw heeft voorgedaan. Door de extreme verscheidenheid zijn op het laatst namelijk geen verschillende ontwikkelingen naast elkaar meer vast te stellen. Er rest nog maar één tijd: de chronologische, met daarin kleine, onafhankelijke ketens van gebeurtenissen, of in dit geval artistieke prestaties. Ongelijktijdigheid heeft hier geen betekenis meer.

$B$ ij het effect van de repeterende breuk en bij de duizeligheid die de historische versnelling teweegbrengt, voegt zich een ander probleem dat vooruitgangsideeën in de kunst bij de voltooid verleden tijd lijkt in te lijven, een probleem dat aan het slot van het derde hoofdstuk werd aangeroerd. In de twintigste eeuw hebben de diverse kunsten namelijk in toenemende mate een reflectie op het eigen esthetische discours in praktijk gebracht. 'To form a School in modern times,' zo schreef de invloedrijke Amerikaanse kunstcriticus Harold Rosenberg in 1959, 'not only is a new painting consciousness needed, but a consciousness of that consciousness [...].'6 Ook kunstwerken uit andere disciplines kregen een steeds groter conceptueel gehalte. De opkomst en invloed van het serialisme in de avant- 
gardemuziek van de jaren vijftig is daarvan een goed voorbeeld. Zo probeerde Karlheinz Stockhausen in zijn reflectie op toonduur en toonhoogte het onderscheid tussen deze twee muzikale grondprincipes muzikaal te doorbreken (o.a. in Gruppen für drei Orchester), terwijl de componist Pierre Boulez zich later toelegde op het 'componeren van ruimte' (zoals in zijn Répons).

Gedichten, muzikale composities, sculpturen, schilderijen of gebouwen dienen inmiddels niet meer alleen in een bepaalde traditie te worden begrepen, maar ook als conceptueel commentaar op andere poëzie, muziek, beelden en architectuur. Dat commentaar is kritisch, bewonderend, afwijzend, ironisch, pedant; het kan iets toevoegen aan een ander kunstwerk, zoals Francis Bacons beroemde Study after Velázquez: Pope Innocent $X$ uit 1953 dat doet; het kan zich door een werk uit het verleden laten inspireren en structureren, zoals Ulysses van Joyce de Odyssee gebruikt, om een modernistisch schoolvoorbeeld te noemen. Het kan een heel genre en een bepaald procédé tot geschiedenis degraderen, zoals de (door Greenberg verwoorde) kritiek in het werk van Amerikaanse schilders in de jaren vijftig en zestig op de schilderkunstige traditie van het perspectief. Of het commentaar thematiseert de eigen activiteit, zoals autonome poëzie het dichten zelf als onderwerp neemt en een film over het maken van een film gaat, met als bekend hoogtepunt Fellini's $81 / 2$; of het is ironisch en eclectisch als bij postmoderne architectuur, die uit het verleden van de bouwkunst citeert; of kunstwerken hebben een filosofische betekenis, zoals bleek uit de in het vorige hoofdstuk geciteerde woorden van Mondriaan, die de Nieuwe Beelding karakteriseerde als 'aesthetische openbaring van het universeele'.

Op een gegeven moment neemt het conceptuele en reflexieve gehalte in de kunst zo toe, dat het de status van de kunst zelf begint aan te tasten. De vraag wat kunst is, wordt steeds vaker in het kunstwerk zelf aan de orde gesteld. Paradoxaal genoeg wordt zo steeds onduidelijker wat kunst is en wat niet. Dit valt mooi te illustreren met het optreden van een galeriehouder in New York, die Marcel Duchamp - aartsvader van de conceptuele beeldende kunst - eens uitnodigde om mee te werken aan 
een tentoonstelling van zelfportretten. De kunstenaar stuurde daarop een telegram: 'This is my portrait if I say this is my portrait.' De galeriehouder hing het telegram op bij de zelfportretten van andere kunstenaars. Toen Duchamp later een rekening bij hem indiende, stuurde de kunsthandelaar een telegram terug met de tekst: 'This is a check if I say it is a check.' 7 In zo'n discours is het niet moeilijk meer van Duchamp een handelaar en van de galeriehouder een kunstenaar te maken, die met zijn telegram het conceptuele kunstwerk van de eerste overtroeft.

Naarmate het conceptuele bestanddeel in kunstwerken groter is, wordt het moeilijker om ze te situeren in een lineaire geschiedenis: kunstwerken vertakken zich in een web van ongelijksoortige relaties, in een telkens veranderende, en vaak dubbelzinnige constellatie, waarin chronologie nog wel een rol speelt, maar eerder als kalender dan als een min of meer logische opeenvolging van periodes. Een kunstwerk kan niet meer in de eerste plaats in de context van een welomschreven traditie worden begrepen, het is vooral deelnemer aan een vaak uiterst complex discours van onderlinge verwijzingen, die bovendien van weinig stabiliteit getuigen. Er mag dan ook worden geconstateerd dat het grote gehalte aan reflectie en commentaar een bij het einde van de avant-garde reeds wankelend geloof in vooruitgangsnoties geen goed heeft gedaan.

Al deze ontwikkelingen betekenen volgens sommigen méér dan een afscheid van de avant-garde. Want is hier niet de hele moderne kunst aan het verdwijnen, is dit niet het eind van een eeuwenlang proces dat overeenkomt met wat zich in de politieke geschiedenis voltrekt, is dit met andere woorden niet een manifestatie van (of variant op) wat sinds Fukuyama als 'het einde van de geschiedenis' populair is geworden? Juist het opsteken van vooruitgangsideeën in deze tegenwoordig veelbesproken kwestie suggereert een intrigerende samenhang. In het tweede hoofdstuk van dit boek is beschreven hoe met de opkomst van het esthetisch domein tegelijk ook ideeën over vooruitgang met een open toekomst een plaats opeisten, en hoe deze twee ontwikkelingen samengingen door het belang dat men in de achttiende eeuw aan de verbeelding begon te hechten. Kunst, 
of beter misschien, de kunsten, kregen pas een eigen identiteit in een zelfstandig, esthetisch domein, toen de koerswaarde van de verbeeldingskracht, de inventio, de lucht in schoot, vanaf het moment dat men de dorpspomp in de steek liet en zich alleen nog maar aan de eigen bron wilde laven, om het beeld van Desmarets de Saint-Sorlin nog eens in herinnering te roepen. Deze verbeeldingskracht speelde een cruciale rol in het veranderende historische denken; door de menselijke creativiteit kon de verwachtingshorizon steeds opschuiven en werd een modern vooruitgangsperspectief zonder finalisme mogelijk.

Het indirecte, en natuurlijk aanzienlijk complexere verband tussen de identiteit van de kunst en vooruitgangsideeën lijkt aan het eind van deze eeuw in spiegelbeeld opnieuw aan de oppervlakte te komen. Want in deze jaren treedt er een op zijn minst suggestieve gelijktijdigheid op tussen het verdwijnen van vooruitgangsbegrippen in de kunst en het identiteitsverlies van de kunsten zelf. Als vooruitgang in de kunsten ijdele fictie blijkt, hebben de kunsten dan nog wel bestaansrecht? Wordt er misschien niet op zeer goede gronden gespeculeerd over het einde van de kunst?

Het is opvallend dat de in de inleiding van dit boek genoemde Arthur Danto zijn these over het einde van de (beeldende) kunst dan ook juist fundeert met kritiek op de idee van vooruitgang in de kunst. Zoals uiteengezet interpreteert Danto de geschiedenis van de kunst niet als een steeds geslaagdere weergave of betere representatie van de werkelijkheid, noch als een allengs verder gaande ontwikkeling van artistieke expressiemiddelen. Zijn geschiedopvatting van de kunst begrijpt de moderne kunst met een beroep op Hegels kunstfilosofie - hoe bizar die theorie ook is, voegt hij er relativerend aan toe - als een manifestatie van toenemend zelfbegrip. ${ }^{8} \mathrm{De}$ (beeldende) kunst krijgt, in de traditie van Duchamp en uitmondend in de jaren zestig, geleidelijk een groter conceptueel gehalte. De vlag van Jasper Johns, Roy Lichtensteins uitvergrote stripfragmenten, de stalen platen van Carl André en de befaamde Brillo Box van Andy Warhol problematiseren allemaal het verschil tussen kunst en werkelijkheid. Een door Warhol uitgestalde zeepdoos is niet 
meer met het oog van een andere zeepdoos te onderscheiden die geen kunst is. Kennelijk zijn het niet meer zichtbare of tastbare kwaliteiten die ertoe doen, maar louter conceptuele. 9

Aldus reflecteert het werk van dergelijke kunstenaars niet alleen op wat kunst is, het wordt zich van zichzelf als kunst bewust en tast daarmee de eigen identiteit van de kunst aan. Daarmee luidt het de doodsklok voor de huidige kunst, die na deze ontwikkeling geen enkel historisch belang meer heeft:

Het historische stadium van de kunst is voorbij, zo gauw bekend is wat kunst is en betekent. De kunstenaars hebben het pad gebaand voor filosofie en het ogenblik is aangebroken waarop het werk ten slotte aan filosofen moet worden overgedragen. ${ }^{10}$

Deze hegeliaanse finaliteit laat geen ruimte aan vooruitgangsbegrippen die een open toekomst vooronderstellen. Omdat er sprake is van een voltooiing, namelijk het bereikte zelfinzicht, heft de kunst zichzelf als historisch verschijnsel op. Het posthistorische tijdperk is angebroken, aldus Danto, die hierbij niet bepaald de toon van Jeremia's klaagzangen aanslaat, al was het wel, zo schrijft hij, 'an immense privilege to have lived in history'."

\section{Opnieuw voorwaarts: bet einde van Arthur Danto}

Het einde van de kunst is de laatste jaren door nogal wat kunstenaars, critici en kunstwetenschappers verkondigd. Maar omdat de meest volledige en overtuigende argumentatie in dit vaak wat schimmig blijvende debat bij Danto is aan te treffen, verdient zijn standpunt de nodige aandacht. Bij geen van de drie manieren om de kunstgeschiedenis vorm te geven - het mimetische perspectief, de opvatting dat kunst in de eerste plaats expressie is van gevoelens of stemmingen en ten slotte de idee dat kunstwerken deel uitmaken van een autonoom, reflexief systeem - is 
het volgens Danto nog mogelijk om van vooruitgang te spreken. ${ }^{12}$

Danto's interpretatie van de eerste kunstopvatting, kunst als representatie, is nogal beperkt. Hij doet het voorkomen alsof deze opvatting slechts betrekking kan hebben op de zintuiglijke verbeelding van de werkelijkheid. Door die reductie van kunst tot visuele representatie van de wereld is het evident dat de schilderkunst en de beeldhouwkunst hun einde vonden in het begin van de twintigste eeuw, toen na de fotografie de filmkunst een dodelijke concurrent bleek te zijn. Die kon immers ook nog eens beweging reproduceren, waar de beeldende kunsten nooit verder zouden kunnen komen dan hooguit een slappe suggestie van beweging. Op zichzelf is de uitvinding en artistieke toepassing van deze genres al een goed argument voor vooruitgang in de kunst, maar als hier nog even van wordt afgezien, valt onmiddellijk op hoe schraal de voorstelling van zaken is die Danto, althans hier, van kunst als representatie geeft. Zelfs de door hem opgevoerde Gombrich heeft met zijn op Popper geinspireerde schema and correction model een aanmerkelijk genuanceerdere opvatting van representatie dan Danto suggereert. Bij Gombrich is de illusie die door het kunstwerk wordt opgeroepen, gereedschap om vat op de verschijningen te krijgen. Wel heeft Gombrich zoveel moeite met abstracte, niet meer direct naar de visuele werkelijkheid verwijzende kunst, dat het probleem van het eind van de geschiedenis in de beeldende kunst zich bij hem ontegenzeggelijk voordoet, zij het op een andere manier dan bij Danto. ${ }^{13}$ Maar met het verschijnen van Nelson Goodmans Languages of Art in 1968, inmiddels een standaardwerk over representatie in de kunsten, is overtuigend aangetoond dat de verschillende kunsten op een aanzienlijk complexere manier naar de werkelijkheid verwijzen, zoals we nog zullen zien. De door Danto gepresenteerde mimetische kunstbenadering is hier slechts één - en dan nog het eenvoudigste - voorbeeld van. Het is dan ook zeer de vraag of er een einde valt aan te wijzen aan de ontwikkeling van de kunst als representatie.

De tweede benadering van kunst, die van kunst als expressie, laat volgens Danto evenmin vooruitgang in de kunstgeschie- 
denis toe. Hier blijkt de tekortkoming van Danto's driedeling, die weliswaar gangbaar is als schema voor verschillende manieren van kunstbeschouwing, maar daarmee nog niet geschikt als karakterisering van manieren van geschiedschrijving in de kunsten. Veel verder dan het voorbeeld Croce zal Danto niet komen. (In het laatste opstel uit The Philosophical Disenfranchisement of Art vervangt hij deze tweede benadering wellicht daarom door een 'geschiedenis van symbolische vormen', met het iconologische werk van Panofsky als voorbeeld. Deze benadering zou echter beter onder representatie kunnen vallen. ${ }^{14}$ ) Maar in dit geval is evenmin duidelijk waarom de kunst een eindpunt zou hebben bereikt. Ziet men kunst als expressie van gevoelens en stemmingen, dan kan men wel degelijk, zelfs aan de hand van een volgens Danto niet-bestaande 'mediating technology of expression', verschillende vormen van ontwikkeling onderkennen. In de loop van de tijd is namelijk een steeds groter en verfijnder scala van artistieke middelen voor expressie mogelijk geworden. Te denken valt aan participatie van - of interactie met - toeschouwers bij performances, of aan de nieuwe beeldtaal van een invloedrijke stroming als het abstract expressionisme. Of op ander gebied: aan de uitvinding van de monologue intérieur in de literatuur, aan kleur-en lichtmanipulaties bij de film en bij videokunst. Waarom zou de 'historische rol' van de kunst hier zijn uitgespeeld?

De derde, 'hegeliaanse' vorm van geschiedschrijving, een soort zelfontplooiing van de Geest in de kunst, is de benadering die door Danto wordt voorgestaan, een benadering die in veel opzichten een adequate inhoudelijke karakterisering van ontwikkelingen in de beeldende kunst oplevert en in die zin ook waardevol is. Toenemende pogingen tot definiëring van wat kunst is, al dan niet 'in essentie', een steeds meer geëxploiteerd, steeds dubbelzinniger en ironischer wordend discours van zelfonderzoek en een telkens weer gethematiseerde reflectie op vernieuwing hebben de eigen identiteit van de kunsten ontegenzeggelijk aangetast en tot probleem gemaakt. Toch is het doen van apodictische uitspraken over de toekomst van de kunst op zijn minst speculatief te noemen. Danto, en gelijkgestemde on- 
heilsprofeten, sluiten in feite uit dat over zeg honderd jaar de beeldende kunsten van vandaag in een perspectief van ontwikkeling zullen kunnen worden bezien.

Dat lijkt moeilijk vol te houden. Want hoe kan Danto ons de garantie geven dat er dan niet opnieuw een Hegel in schaapskleren op zal staan, die verkondigt dat na de grote voortgang die in de afgelopen eeuw geboekt is - en die pas werkelijk in kon zetten met een diepgaande reflectie zoals die destijds zo meesterlijk verwoord werd door de kunstcriticus en filosoof Arthur Danto - dat na deze imponerende eeuw van vooruitgang, waarmee de drempel van het derde millennium zo overtuigend werd genomen, de beeldende kunsten eindelijk hun volkomen realisatie hebben bereikt? De verkondiging van het einde in de beeldende kunsten is bovendien ook minder verrassend dan het publiek soms denkt; deze apocalyptische aanzeggingen zijn sinds Dada regelmatig aan te treffen, bijvoorbeeld, zo bleek in het vorige hoofdstuk, in De Stijl, dat een manifest van Van Doesburg over het einde van de kunst publiceerde en enkele jaren eerder reeds bij monde van Mondriaan stelde dat de kunst 'in traditioneelen zin [...] al meer verloren' ging. 's

De hypothese van het einde van de kunst als historisch fenomeen verliest nog meer terrein wanneer andere kunsten in deze analyse worden betrokken. Weliswaar valt daar een vergelijkbaar gevoel van crisis niet te ontkennen, maar zelfs wanneer dit gevoel veroorzaakt wordt door het telkens kraaien van revolutie en een hieruit voortspruitende beleving van onophoudelijke versnelling van de tijd, dan wil dat nog niet zeggen dat alle toekomstmogelijkheden voor de kunst daarmee hebben afgedaan of per postmodern decreet kunnen worden afgeschaft. En voor zover deze crises te wijten zijn aan een (al dan niet hegeliaanse) toename van reflectie en conceptualisering, zegt dit nog weinig over de mogelijkheid van vooruitgang in de kunst, zoals in het volgende hoofdstuk beargumenteerd zal worden.

Ten slotte is Danto's beschouwing van beeldende kunst te eenzijdig, omdat hij zich tot het derde, hegeliaanse perspectief beperkt. Het discours van de beeldende kunsten bevat niet uitsluitend conceptuele uitingen, het is evenzeer doordesemd van 
vormen van representatie en expressie. Die mogen dan wel vaak door conceptuele verwijzingen beïnvloed zijn, ze zijn er niet volledig toe te herleiden. Zo zijn de recente schilderijen van de door Danto gewaardeerde Sigmar Polke vaak figuratief. De herkenbare taferelen verwijzen dan natuurlijk niet naar de werkelijkheid zoals een portret van Anthonie van Dyck of de waterlelies van Monet dat doen, maar ze zijn anderzijds niet volledig te herleiden tot formele verwijzingen en filosofische concepten, wat uit Danto's opvattingen lijkt te moeten volgen. Verder spreekt uit Polkes werk een zekere stemming of emotionele lading, die deels bepaald wordt door verwijzingen naar andere schilders en tradities, daar echter niet geheel op is terug te voeren. Zo'n lading is alleen al niet geheel irrelevant omdat het publiek het werk vanuit een gevoelsmatige houding benadert, waarvan Polke zich bewust is en waar hij op reageert.

Dit kan ook worden geillustreerd aan het werk van Jeff Koons, dat zonder twijfel in de eerste plaats begrepen en bekeken dient te worden in het conceptuele kader dat Danto voor de huidige beeldende kunst zo kenmerkend acht. Koons' oeuvre is pas goed toegankelijk voor wie zich bewust is van het eigentijdse discours van de beeldende kunst; het verkent de grenzen van wat nog kunst is door bij tentoonstellingen uitvergrote, opgeblazen, en vaak gekopieerde kitsch te laten zien (Banality, 1988) of door pornografie af te beelden waarin de kunstenaar zelf een grote rol speelt (Made in Heaven, 1991). Koons lijkt bij uitstek een voorbeeld voor Danto's optiek, want zijn werk bestaat bij de gratie van een even ingewikkeld als ironisch spel met verwijzingen en commentaar. Toch gaat het te ver elke representationele en expressieve betekenis aan dit werk te ontzeggen. Zo is Ilona's House Ejaculation, een zeefdruk ( I $\{2,4$ x 228,6 cm) uit I 99 I naar een sterk uitvergrote pornografische foto, waarop de ejaculerende kunstenaar en zijn echtgenote, de Italiaanse pornoster en politica Ilona Staller staan afgebeeld, ontegenzeggelijk een statement in het huidige kunstdiscours. Maar het verwijst even onontkoombaar naar de werkelijkheid, en bepaald niet alleen via symbolische codes. Bovendien mag dit werk emoties oproepen (opwinding, afschuw, verwarring, verbazing, 
ergernis, lacherigheid), het drukt ze ook uit. Zo geeft de sterk uitvergrote, gedetailleerd weergegeven seksuele intimiteit binnen de door elkaar geschoven referentiekaders van pornografie en artistiek systeem een vervreemdende, koele distantie weer ten opzichte van een doorgaans uiterst persoonlijke belevingswereld. Deze confrontatie van het extreem van intimiteit met dat van anonieme openbaarheid, en van het laag-bij-de-gronds geachte cliché met verheven artistieke bedoelingen laat weinig beschouwers van nu onberoerd. In de woorden van een bewonderaar van Koons, de Frankfortse museumdirecteur JeanChristophe Ammann:

Koons' Leidenschaft für das Künstliche, Niedliche, Manierierte, Barocke in Stil, Werbung und Nippes verbindet sich mit der Kälte eingefrorener, reduzierbarer, regredierter $\mathrm{Ge}$ füble. ${ }^{16}$

Zonder dat hier nu verder met Jeff Koons' gevoel voor detail op in wordt gegaan, mag duidelijk zijn dat het einde van de beeldende kunst, waar Danto in gelooft, slechts houdbaar is door representatie en expressie als verouderd en irrelevant af te doen. Dat getuigt van een veel te beperkt perspectief, helemaal wanneer we ook andere kunsten in ogenschouw nemen. Telkens zien we dan dat in de kunst een mengvorm optreedt van representatie, expressie en conceptuele verwijzingen. Misschien speelt de eerste een grotere rol in de literatuur, terwijl de laatste dat in de muziek doet; een roman geeft immers een beschrijving van een (fictionele) werkelijkheid, de tonen van een muziekstuk verwijzen vaak naar andere muziek of hebben een expressieve functie. Maar van een universele verdamping in abstracte concepten zoals Danto bij de beeldende kunsten meent te ontwaren, is geen sprake. Zo is de dood van de roman deze eeuw al vele malen verkondigd, soms met indrukwekkende argumenten; toch worden er niet minder nieuwe (en vernieuwende) romans geschreven en gelezen. Van het theater en van muziek kan iets vergelijkbaars worden gezegd, om niet te spreken van nieuwere kunstvormen als film en video-kunsten, die overigens tot nu toe 
meestal nog van zulke aanzeggingen gevrijwaard blijven.

De opvatting van Danto vertegenwoordigt een reeks aanvechtbare pogingen om de kunst (als historisch fenomeen) af te schaffen, of beter: hegeliaans op te heffen en tot filosofie te laten worden door de kunst een toenemend 'zelfbegrip' toe te schrijven. Met dit geproclameerde doodvonnis van de (beeldende) kunst schaart hij zich in een even lange als discutabele filosofische traditie. Ook hier blijkt artiphilosophia lupus: de filosofie is voor de kunst een wolf. Vanaf Plato's leerlingen tot aan Hegel, en daarna telkens opnieuw, hebben filosofen het bestaaninsecht van de kunsten aangevochten en hun mogelijkheden beperkt door kunst te interpreteren als een vorm van filosofie, die illustratie is, en daarmee eigenlijk overbodig, dan wel een vorm die eigenlijk al lang overwonnen is.

\section{Afscheid van vooruitgang?}

Een van de grote verdiensten van het debat over postmodernisme schuilt in het aan de oppervlakte komen van de vooruitgangsnoties die nog altijd in ons hoofd rondspoken. Maar in de kunsten heeft het postmodernisme zulke intuïties over het verleden theoretisch verschalkt, zonder dat dit in de praktijk veel vruchtbaars heeft opgeleverd. Want waar in de kunst, als resultaat van het afscheid van de geschiedenis, de zo vaak bezongen totale vrijheid gevierd wordt van het anything goes, gaat dit onveranderlijk gepaard met een onbehaaglijk gevoel van vrijblijvendheid, dat die vrijheid veel van haar luister ontneemt. De door Nietzsche destijds zo opgewekt bepleite afschaffing van het verleden ontslaat iemand die handelt namelijk nog niet van de noodzaak om een toekomst te ontwerpen die het heden betekenis en zin kan verlenen. Elke kunstenaar zoekt een weg in de tijd, heeft in en door de geschiedenis een mogelijkheid tot oriëntatie, die voor het maken van kunst onontbeerlijk is, zoals elke kunstbeschouwer kunstwerken in een context interpreteert die altijd ook een historische dimensie heeft.

Het is dus de vraag wat eigenlijk de winst is van het ahistori- 


\section{Het einde van de kunst}

sche tijdsbewustzijn dat in de kunsten is opgedoken. Misschien gooien kunstenaars en kunstbeschouwers historische categorieën wel erg lichtvaardig overboord: zolang de kunsten van een bepaalde koers in hun ontwikkeling getuigen, lijkt het even pathetisch als improduktief om kaart, kompas en sextant van zich af te werpen. Dit impliceert echter dat de kunsten zich inderdaad in een bepaalde, niet onwenselijke richting kunnen ontwikkelen.

$\mathrm{Nu}$ inmiddels gebleken is dat de eindtijd in de kunsten nog wel even op zich kan laten wachten, wordt de discussie over vooruitgangsideeën daarom opnieuw van groot belang. In het bovenstaande zijn al suggesties te vinden voor de manier waarop dergelijke ideeën aan actualiteit kunnen winnen. Toch moeten, voor hier in het laatste hoofdstuk op wordt ingegaan, nog enkele andere bezwaren worden genoemd. Voor het te kort schieten van vooruitgangsbegrippen als instrument om de geschiedenis van de kunsten te beschrijven zijn in het begin van dit boek reeds argumenten aangevoerd die het bij zulke concepten veronderstelde begripsrealisme aan de kaak stelden, hoewel ze niet elk spreken over vooruitgang zinloos maakten. Er zijn echter nog meer, deels populaire vormen van scepsis ten aanzien van vooruitgang in de kunsten.

Om te beginnen kan een eerder aangehaalde uitspraak van Thomas Kuhn worden gememoreerd, namelijk dat waar in wetenschap kennis uit het verleden heeft afgedaan, kunstwerken van vroeger gewoon mee blijven tellen. $\mathrm{Na}$ het succes van Picasso wordt het werk van Rembrandt immers niet minder gewaardeerd. Het verleden, zo werd eerder betoogd, blijft in de kunsten massaal en massief aanwezig. Wat later gemaakt wordt, hoeft immers nog niet beter te zijn, evenmin als oudere meesterwerken slechter (of beter) zijn dan latere. Welke standaard zou hier ook voor moeten gelden, als er geen absolute en tijdloze criteria in de kunst zijn aan te treffen? Er bestaat nu eenmaal, zoals de Russische dichter Osip Mandelstam het in 1921 uitdrukte, geen literair mechanisme, en het is evenmin een uitgemaakte zaak of er niet evenveel verloren gaat als wat erbij komt. Zelfs binnen het oeuvre van één schrijver is dat al duidelijk, want, zo schrijft hij, 
[w]aar is bij de Tolstoj, die zich in Anna Karenina bet construerend vermogen en de psychologische vaardigheid van de Flaubert-roman beeft eigen gemaakt, het natuurlijk instinct en de fysiologische intuitie gebleven van Oorlog en vrede? En waar is in Oorlog en vrede de doorzichtige vorm, het 'clarisme' gebleven uit Kinder- en jongensjaren?

Volgens Mandelstam kun je net zo goed een geschiedenis van verworvenheden schrijven als een van alles wat verloren is gegaan, en beide gaan over hetzelfde. ${ }^{17}$

Een bijkomstig, maar niet onbelangrijk probleem is hier dat vooruitgang (of het denken in termen van verworvenheden) een waarde-oordeel veronderstelt, dat op zijn beurt evenzeer aan verandering onderhevig is. Een liefhebber van romantische muziek zou de ontwikkeling van barok via classicisme naar romantiek als vooruitgang kunnen interpreteren, maar Messiaen of Sjostakovitsj niet meer als handhaving of voortzetting van het niveau van Chopin of Tsjaikovsky kunnen bezien. Het perspectief van waaruit een ontwikkeling geëvalueerd wordt, is van waarde-oordelen afhankelijk. Omdat de normen veranderen, blijft wat inhoudelijk met vooruitgang bedoeld wordt niet gelijk. Daarom zijn er telkens nieuwe historische verhalen geconstrueerd, als een door Vooruitgang bepaalde voorgeschiedenis van het heden die meestal door de normen van het heden is ingegeven. Deze tijdsafhankelijkheid van normen dwingt ons tot het aanbrengen van verschillende niveaus: niet alleen de stand van zaken in een bepaald tijdvak verandert, maar ook het perspectief op dat tijdvak is aan verandering onderhevig.

De normatieve lading van het vooruitgangsbegrip blijkt telkens problematisch. Karel van het Reve verduidelijkte dit eens in een lezing over vooruitgang in de kunst met zijn categorische stelling dat er na Mozart wel andere, maar geen betere muziek is geschreven. ${ }^{18} \mathrm{Zijn}$ (wat ironisch getoonzette) stelligheid onderstreept de bij velen levende opvatting dat oordelen in de kunst slechts een schijnbaar beroep op objectiviteit kunnen doen: een ander kan met hetzelfde aplomb Beethoven, Bach of een hedendaags componist als hoogtepunt noemen. Wie het smaakoor- 
deel in de kunst volstrekt subjectief acht, heeft vanzelfsprekend geen enkele boodschap meer aan vooruitgangsnoties, die immers van bepaalde normen uitgaan.

De idee van vooruitgang in de kunst is niet alleen onzinnig, zo meende Van het Reve in dezelfde lezing, het is ook schadelijk. De kunstenaar zal al gauw gedreven worden door weinig werkelijk stimulerende drijfveren als plichtsgevoel jegens de vooruitgang en angst om voor ouderwets te worden aangezien, terwijl de consument van kunst zich aftobt met eigentijdse werken ten koste van de tijd en de energie die aan meesterwerken uit de geschiedenis hadden kunnen worden besteed.

Zulke scepsis richt zich niet op het descriptieve vooruitgangsbegrip, maar verzet zich tegen de prescriptieve aanspraken ervan. In de tweede helft van deze eeuw duiken dergelijke bedenkingen telkens op. Over de negatieve uitwerking van het progressieve denken in de kunst is in de loop van dit boek al het een en ander gezegd. Scepsis jegens het prescriptieve vooruitgangsbegrip was echter lange tijd geen bon-ton en kwam in de ogen van velen neer op het rituele gemopper van conservatieve critici. De laatste decennia begonnen echter steeds meer kunstenaars te lijden onder de ideologie van de vooruitstrevendheid. De Britse schrijver en schilder Wyndham Lewis (1884-1957), oorspronkelijk van onbesproken avantgardistische signatuur, wijdde in 1954 aan zulke reserves zelfs een heel boek, waarvan de titel al voor zich spreekt: The Demon of Progress in the Arts. Ook in de kunst zelf kwam het vooruitgangsdenken expliciet onder schot te liggen. ${ }^{19}$

Omdat de kunsten in de loop van de tijd in een allesbeheersend vooruitgangsperspectief waren komen te staan, werd er door kunstenaars en critici in toenemende mate over de rol en de identiteit van kunst nagedacht. De geschiedenis ging bij elke daad over de schouder meekijken, waarmee de kunst zich langzaam maar zeker van haar vanzelfsprekendheid ontdeed. Ze voelde zich verplicht verantwoording af te leggen tegenover de tijdgeest. Zo bezien verloor de kunst door Vooruitgang haar onschuld, om het eens op de manier van de Franse intellectueel te zeggen, en begon ze eind vorige eeuw, met de opkomst van 
het modernisme, geleidelijk conceptueel te worden.

Deze door Danto in wat andere bewoordingen geschetste ontwikkeling liep parallel aan een gedaanteverwisseling waarin de historische oriëntatie en legitimatie van het kunstwerk steeds meer op de voorgrond kwamen. Om redenen die in het vierde hoofdstuk zijn beschreven, ontstond geleidelijk een progressieve ideologie, die uitmondde in een imperatief van de vooruitgang. Kunstenaars dienden de historische route te volgen, een route met eenrichtingsverkeer en een stopverbod. Kunst moest allengs meer experimenteel zijn, vernieuwingen werden steeds vaker beoordeeld naar de mate van verandering en minder naar andere, inhoudelijke maatstaven. Jong talent werd het summum; experiment, avant-garde, revolutie en provocatie werden toverwoorden, nog lang nadat ze tot op de draad versleten waren geraakt. Kritiek verloor gezag omdat ze gebukt ging onder de angst het nieuwste te miskennen en zo door Vooruitgang op een zijspoor te worden gerangeerd. ${ }^{20}$

De laatste jaren heeft de kunstkritiek zich hiervan echter hersteld. Er vielen klachten te beluisteren over voorstellingen die in gewild geëxperimenteer bleven steken, over onleesbare boeken, ongenietbare muziek, rituele vernieuwingsdrift. Nieuwe generaties kunstenaars zetten zich met succes af tegen gecanoniseerde vernieuwers en hadden hierin verwarrend genoeg hun leeftijd mee, talloze avantgardistische experimenten liepen dood in obligate herhaling. De nouveau roman, het gedicht als ding dat naar niets buiten zichzelf verwijst, de seriële muziek, de modernistische architectuur, langzaam aan verdwenen ze van de kaart. De voorhoedes losten op, mede door een uit de avantgarde afkomstige, in bijna alle kunstvormen oprukkende vermenging van elitekunst en 'lower culture', een wisselwerking die het nog moeilijker maakte om aan te wijzen wat verder en wat minder voortgeschreden was.

Voor wie de rekening opmaakt lijkt het doek voor de idee van vooruitgang in de kunst alsnog te vallen. Het begrip is oudbakken, verleden tijd, geschiedenis. Het schiet te kort als beschrijvend model, het heeft een alomtegenwoordige crisis in de kunsten in de hand gewerkt, het maakt kunstenaars ongelukkig en 
kunstliefhebbers onzeker. Toch wil dit boek niet de zoveelste steen op het graf van de vooruitgang zijn. Want 'oudbakken', 'verleden tijd', het 'post-moderne' en 'post-historische' rijdperk van Danto, al dergelijke termen dragen nog een tijdselement met een evaluatieve waarde in zich, dat niet geheel van vooruitgangssmetten vrij lijkt te zijn. ${ }^{2}$ Ook hier is het tweede werk van Herakles kennelijk nog niet voltooid: het monster Vooruitgang steekt telkens de kop weer op. Het staat de laatste jaren, dankzij het postmodernisme en theorieën als die van Danto, opnieuw in allerlei vermommingen op de agenda. 


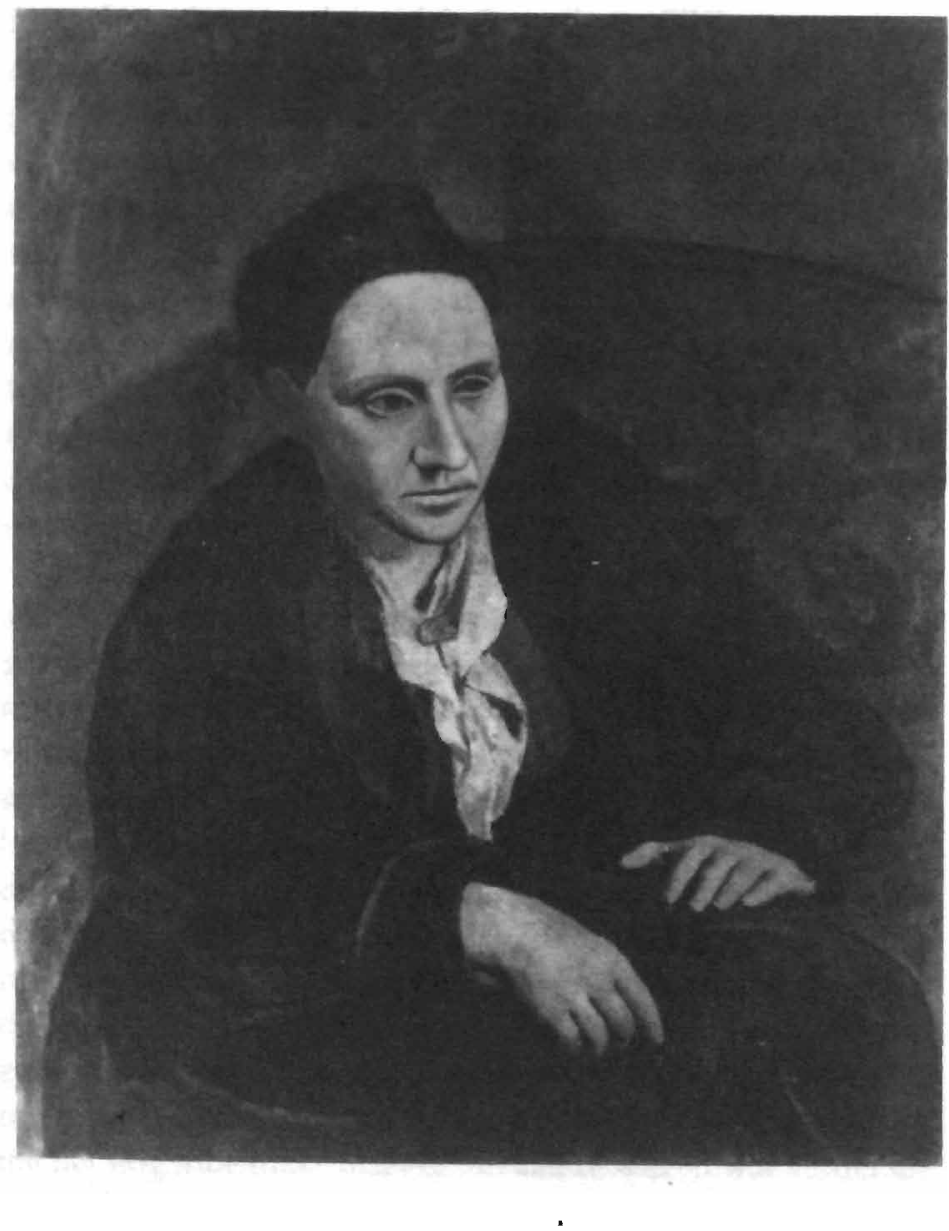

Pablo Picasso, 'Portiet van Gertrude Stein' (1906; 81 x 100 cm) 


\title{
8 Steeds meer en steeds rijker
}

\author{
Zolang men een zaak nog niet beeft afgehandeld bestaat \\ er altijd de kans dat bij zich in gunstige zin ontwikkelt.
}

Italo Svevo'

Vooruitgang, zo is aan het slot van het eerste hoofdstuk betoogd, veronderstelt dat ontwikkelingen een zekere continui-teit en richting vertonen, dat er sprake is van cumulatie van de onderhavige verschijnselen en dat de verandering in deze ontwikkelingen wenselijk wordt geacht. In hoeverre blijft er nu voor iemand van deze tijd, ondanks alle scepsis, ruimte over om geloof te hechten aan vooruitgang in de kunsten? Voor een dergelijke vooruitgang zijn grofweg twee soorten argumentatie te geven. Argumenten van het eerste soort scharen zich onder de leuze dat kunst weliswaar niet steeds mooier (beter, leerzamer, ontroerender, overtuigender, etc.) wordt, maar dat er wel steeds meer kunst bij komt. Het tweede soort argumentatie benadert kunst als cognitief systeem, waarmee een steeds rijkere interpretatie van de werkelijkheid mogelijk wordt.

\section{Vooruitgang in de kunsten: steeds meer}

De eerste argumentatievorm stoelt op een kwantitatief principe, het feit namelijk dat er in de loop der tijd telkens meer technieken, procédés, uitdrukkingsmiddelen en stijlen ter beschikking komen, steeds meer kunstwerken en zelfs hele nieuwe kunsttakken. ${ }^{2}$ De toepassing van acrylverf, uitvinding van de collage, het overnemen van muzikale principes van nietwesterse volken, gebruik van het toeval in composities, andere mogelijkheden van belichting bij het toneel, het twaalftoonsysteem, de flash-back, de monologue intérieur, parlandopoëzie, de rol van de computer in diverse kunsten en nog talloze 
andere nieuwe technieken en procédés; het ontstaan van kunstvormen als opera, fotografie, film en videokunst, of van genres als het sonnet, de symfonie, het naakt, of televisiedrama; maar bovenal een gestaag toenemende hoeveelheid gerealiseerde kunstwerken - alle duiden op een min of meer samenhangend proces. Dit proces, of beter: deze processen zijn cumulatief en vertonen ook continuïteit in die zin dat het niet voorkomt dater plotseling veel minder procédés en technieken zijn, grote aantallen kunstwerken worden weggevaagd of hele kunstdisciplines verdwijnen. (Strikt genomen bestaat die mogelijkheid natuurlijk wel door onze beschikking over massavernietigingswapens. Een voorproefje bood de in beide wereldoorlogen kapotgeschoten en platgegooide architectuur.) Zolang we ervan uit kunnen gaan dat een toename van stijlen en procédés, van kunstwerken en kunstdisciplines een verrijking betekent, is het geen slag in de lucht om hier van vooruitgang in de kunsten te spreken, hoe triviaal het argument op zichzelf ook is. Zelfs in een tijd zonder Rafaëls en Carracci's, om het argument van Condorcet te herhalen, hoeft er nog geen terugval te zijn, omdat we de verworvenheden van het verleden bewaren.

In hoofdstuk s en 6 werden voorbeelden van kwantitatieve vooruitgang meer in detail beschreven, zoals in de vergelijking van de poëticale gedichten van Sierksma en Lucebert. Hier bleek de laatste een rijker arsenaal aan stilistische middelen te gebruiken, waarvan dubbelzinnigheid het meest opvallend was. $\mathrm{Bij}$ De Stijl is geschetst hoe er een nieuwe beeldtaal werd uitgevonden, een taal waarin harmonie met vermijding van symmetrie een centraal principe was dat door de architectuur en de schilderkunst in praktijk werd gebracht. Te denken valt ook aan de nieuwe manier waarop uitdrukkingsmiddelen in de schilderkunst werden gebruikt, namelijk zonder verwijzing naar een zichtbare werkelijkheid.

De kwantitatieve toename in de kunsten vindt op nog een andere manier plaats. Talloze kunstwerken leveren commentaar op vroegere kunstwerken; ze ontlenen niet alleen hun kracht en betekenis aan de traditie waarin zé ontstaan, maar voegen aan de werken van die traditie iets toe. Picasso's schetsen en schilde- 
rijen naar aanleiding van Velásquez' Las Meninas stelt de toeschouwer voortaan in staat ook met Picasso's plezier, met diens accentuering van kleur en vorm naar het meisje met het hondegezichtje uit dit groepsportret te kijken. Tirso de Molina's El burlador de Sevilla is als Don Juan in de daaropvolgende eeuwen nieuwe luister bijgezet door Mozart, Byron en Poesjkin. J.S. Bach werd aan de vergetelheid onttrokken en vervolgens op een volstrekt nieuwe manier geïnterpreteerd door Mendelssohn en door een daarna in omvang steeds toenemende traditie van Bach-interpretaties.

Martin Seel ziet in dergelijke onderlinge confrontaties van kunstenaars en kunstwerken terecht een verrijking door het accentueren van verschillen. Voor hem is dit een belangrijk argument voor vooruitgang in de kunsten. In de kritiek, die Barnett Newman vanuit zijn esthetica van het sublieme met Who's afraid of red, yellow and blue? op 'de idealiserende abstractie' van Mondriaan leverde, zo betoogt Seel, wordt een esthetisch verschil (difference) gearticuleerd, in plaats van dat de ene kunstenaar de andere weerlegt:

We, perceiving the aesthetic force of both Mondrian and Newman, decide not to decide this controversy-for reasons given to us by the best works of these painters. 3

Niet-artistiek commentaar van kunst-, literatuur- en muziekhistorici en van critici en filosofen voegt eveneens interpretatiemogelijkheden toe die de kunst verrijken. Hegels commentaar op Antigone en dat van Heidegger op Hölderlin kunnen hier als voorbeeld dienen, of de invloed die de esthetica van Schopenhauer heeft gehad op de interpretatie van kunst, ook bij kunstenaars zelf, zoals bij Mondriaan bleek en bij Wagner nog veel sterker naar voren komt.

Dat neemt niet weg dat aan het laatste argument een keerzijde zit, een probleem dat in het vorige hoofdstuk al werd aangesneden. Want naarmate kunst meer commentaar begint te leveren en naarmate zij dus conceptueler wordt, raakt haar identiteit in het geding. Wanneer dit zo ver gaat als Danto schetst - en bij 
sommige beeldende kunst is dat inderdaad zo, en bij sommige poëzie en romans - gaat kunst in filosofie (of conversatie) over. Dat kan natuurlijk als vooruitgang worden opgevat, maar vooruitgang in de kunst is het dan niet meer. Waar echter de kritische grens ligt van wat een kunstwerk aan conceptueel gehalte kan verdragen, is niet eenvoudig vast te stellen, al staat de kritiek hier nu ook weer niet met lege handen.

Bovengenoemde kwantitatieve argumentatie laat in het midden of er geleidelijk aan een hoger artistiek peil ontstaat in de produktie en receptie van kunst. Deze kwestie valt niet te beslissen, omdat het smaakoordeel aan verandering onderhevig is, zoals in het vorige hoofdstuk werd beargumenteerd. Daarom kan vooruitgang niet in termen van zuiver artistieke kwaliteit worden beschreven, wanneer er al zoiets zou bestaan. Een voorbeeld mag dat verduidelijken. Stel dat iemand, of een groep connaisseurs, zich afvraagt of binnen een bepaalde periode, tussen tijdstip A en tijdstip B, in een bepaalde kunsttak van vooruitgang in artistieke zin kan worden gesproken, zeg tussen $1800 \mathrm{en}$ 1875 in de Nederlandse poëzie. Dan maakt het veel uit of deze vraag beoordeeld wordt vanuit de gangbare smaak in 1875 , in 1935 of in 1995 . Het smaakoordeel is dus net zo goed temporeel bepaald als de ontwikkelingen waarop dat oordeel betrekking heeft. Gezien de in de kunsten steeds veranderende kijk op het verleden is dit een onoverkomelijk probleem. Daarom gaat het er met andere woorden bij vooruitgang in de kunsten niet om of er na Mozart mooiere muziek is geschreven, maar dat er daarna nog veel andere muziek is geschreven en uitgevoerd.

De eerder genoemde vergelijking tussen wetenschap en kunst van Kuhn pleit dan ook niet tegen de bruikbaarheid van vooruitgangsbegrippen in de kunst. Integendeel zelfs. In wetenschap is een bepaalde mate van vooruitgang, of beter: groei van kennis, mogelijk doordat theorieën overboord worden gezet, in de kunsten bestaat vooruitgang omgekeerd juist mede uit het bewaren van resultaten uit het verleden. Met Copernicus, Galilei en Newton verdwijnen Ptolemaeus en Aristoteles van het toneel, met de komst van Picasso en Mondriaan wordt Rembrandt niet van de muur gehaald. Men bouwt er gewoon nog 


\section{Steeds meer en steeds rijker}

een museum bij. Naast de poëzie van W.H. Auden en Hugo Claus leest men Petrarca en Hooft. Met andere woorden: theorieën verstoten elkaar, kunstwerken verrijken elkaar.

Binnen deze kwantitatieve benadering blijft het een probleem dat wellicht niet volledig van kwaliteit, dus van de artistieke verdiensten van kunstwerken, kan worden afgezien. Wie bijvoorbeeld de literatuur of de beeldende kunsten in de Sovjetunie tussen 1925 en 1985 in ogenschouw neemt, zal een kwantitatieve toename niet ontkennen, maar de ontwikkelingen in deze periode, althans binnen de grenzen van deze cultuur, denkelijk niet als vooruitgang willen karakteriseren. Anderzijds wordt de mogelijkheid van zo'n vooruitgang daarmee nog niet ontkend; men spreekt hier, terecht, van 'stilstand'.4

Het verschil tussen kwalitatief en kwantitatief is overigens betrekkelijk. Want kunst veronderstelt altijd een bepaalde artistieke kwaliteit. Hoe moeilijk die ook is vast te stellen of te omschrijven, hoe tijdgebonden en contextafhankelijk die ook is, beneden een zeker niveau - volgens de criteria van een welomschreven periode - zijn artefacten geen kunst meer omdat ze niet meer als zodanig worden erkend. Aangezien kunst altijd verscheidenheid en variatie vertoont, zelfs op het niveau van het individuele oeuvre van de kunstenaar, die zichzelf immers niet eindeloos kan herhalen, ontstaan steeds meer verschillende kunstwerken van (een achteraf nog herkenbare) kwaliteit. Door deze verscheidenheid neemt de algemene kwaliteit toe, zolang men die tenminste niet als een soort stijgend artistiek moyenne wenst te interpreteren.5

Een misschien wat merkwaardig probleem bij deze kwantitatieve redeneertrant is dat aannemelijk dient te worden gemaakt dat de hoeveelheid kunst die door teloorgang en door veranderende smaak aan de vergetelheid wordt prijsgegeven, niet opweegt tegen wat er aan nieuws bij komt, een argument dat niet zo zwaar lijkt te tellen in een tijd waarin zoveel kan worden gereproduceerd en opgeslagen en waarin de produktie en consumptie van kunst zozeer is toegenomen. Maar het is niet heel eenvoudig om die schier eindeloze rij schimmen van ooit gevierde kunstenaars die uit het zicht is geraakt, en de talloze ver- 
loren gegane kunstwerken te verdisconteren. Kan er niet net zo goed, Mandelstam volgend, een geschiedenis worden geschreven van wat we kwijt zijn geraakt als een geschiedenis van verworvenheden? Dat verlies wordt verergerd doordat kunstwerken uit het verleden in een vaak heel andere context figureerden; niet elke verwijzing of expressie is nog begrijpelijk.

Wat dat laatste betreft kan echter veel weer inzichtelijk worden gemaakt, zoals het iconologische werk van Erwin Panofsky heeft geillustreerd en zoals ook de bloeiende authentieke uitvoeringspraktijken van oude muziek de laatste decennia hebben aangetoond. Verder mogen er veel kunstwerken verloren gaan, feit is dat er over het geheel genomen steeds meer bij komt en dat 'meesterwerken en topstukken' in het algemeen ook nog een voorkeursbehandeling krijgen bij het conserveren, uitvoeren, tentoonstellen en publiceren van kunst. Bovendien zijn veel procédés, stijlmiddelen en technieken verworvenheden waarvan men gebruik kan blijven maken. Mandelstam kon zich wel afvragen waar 'het natuurlijk instinct en de fysiologische intuïtie' van Oorlog en vrede en Anna Karenina gebleven zijn, maar Tolstoj had ze opnieuw toe kunnen passen. Ze zijn niet verloren, zoals Mandelstam suggereert, en hij weerlegt dit eigenlijk ook door, notabene in dezelfde zin, bij Anna Karenina te spreken van 'het construerend vermogen en de psychologische vaardigheid van de Flaubert-roman'. Zo geeft hij toe dat je artistieke technieken en vaardigheden uit de geschiedenis, in dit geval die van Flaubert, kunt blijven gebruiken.

Iets vergelijkbaars zien we bij de Vijftigers, om nog een voorbeeld te geven. Men zou hier kunnen opwerpen dat sinds hun doorbraak een aantal dingen niet meer mogelijk was. Want wie durfde er nog een sonnet te schrijven na de hatelijke veroordeling ervan door Lucebert en Kouwenaar, die in I955 beweerde dat er 'geen terug meer' was?6 Niettemin verschenen al weer in 1957 De sonnetten van de kleine waanzin van Vijftiger Hans Andreus, een bundel die uitsluitend uit sonnetten bestond, hoewel ze niet altijd op de klassieke manier rijmden. En vijftien jaar later was het sonnet in de Nederlandse poëzie weer volop in de mode. 
Cognitieve vooruitgang: kunst als kennis

De belangrijkste argumenten voor vooruitgang in de kunsten zijn echter niet van kwantitatieve aard, maar gaan uit van het cognitieve gehalte van kunst. Deze opvatting, zo bleek eerder, is te bespeuren bij Gombrich, zij het in beperkte zin. Want het probleem bij Gombrich was dat hij het mimesis-ideaal van de renaissance niet echt los wilde laten. Dat levert moeilijkheden op. Ten eerste is de toenemende vaardigheid van renaissancekunstenaars om de werkelijkheid te verbeelden op zichzelf niet zomaar in termen van vooruitgang te beschrijven. In Wissenschaft als Kunst illustreert Feyerabend dit door erop te wijzen dat Vasari en zijn tijdgenoten een veel natuurlijker afbeeldingswijze meenden te bezitten, omdat de schrille kleuren, het felle rood en groen van gewaden, het goud rond de heilige hoofden en gebruik van ultramarijn voor de hemel niet meer door hen werden toegepast. Hoewel ze dat als een vorm van vooruitgang beschouwden, bemerkten ze niet dat er in deze beoordeling nieuwe, mimetische criteria waren binnengeslopen. Dat kleurgebruik van hun voorgangers moest namelijk juist de onnatuurlijkheid, het hemelse en zinnebeeldige accentueren.7

Gombrich kan met zijn ideaal van representatie overigens, fascinerend genoeg, tot in de negentiende eeuw redelijk uit de voeten, maar vanaf de uitvinding van de fotografie, en later de film, slaat de beeldende kunst een richting in die Gombrich elk houvast ontneemt. Vanaf deze periode namelijk gaan mentale operaties van de kunstenaar opeens veel meer de plaats innemen van ambachtelijke, zuiver schilderkunstige vaardigheden; de verwijzing naar de werkelijkheid wordt vanaf de ready-mades van Duchamp, en helemaal in de conceptuele kunst sinds de jaren zestig, uiterst ingewikkeld, zoals Danto liet zien.

In dit opzicht is de cognitieve benadering van vooruitgang in de (beeldende) kunst van Suzi Gablik interessant. Haar Progress in Art (1976) begint met de constatering dat velen - waarbij ze stellig ook aan Gombrich denkt - menen dat de hedendaagse kunst geen toekomst meer heeft. ${ }^{8}$ Een dergelijk einde van de kunst, een ander dan Danto tien jaar later uit zou dragen, wordt 
door mensen verkondigd die geen raad weten met nietmimetische kunst van Malevitch en Mondriaan tot en met Pollock en Stella. Om aan te tonen dat de moderne kunst niet failliet is, ontwikkelt Gablik een model voor vooruitgang in de (beeldende) kunst. Ze vertrekt vanuit de ontwikkelingspsychologie van Piaget, die cognitieve systemen verschillende stadia laat doorlopen om de omgeving op een steeds complexere manier in kaart te kunnen brengen. In deze zienswijze wordt de wereld deels gestructureerd door cognitieve vermogens, deels worden die vermogens juist omgekeerd door de omgeving beïnvloed. Analoog aan Piagets ontwikkelingsstadia van het individu ontwerpt Gablik een structurele cognitieve ontwikkeling in de geschiedenis van de beeldende kunst, waarin ze drie zogenaamde megaperiodes aanbrengt, die elk de ruimte op een eigen manier constitueren en beschrijven. 9

Itrut vroege gescrihèents worat ruimte 'subjèctiet 'georganiseerd. Objecten zijn tweedimensionaal weergegeven: er is nog geen globale indeling waarin diepte en afstand tot uitdrukking kunnen worden gebracht. Dit is te zien in de beeldende kunst van de Egyptenaren, de oudheid, de Grieks-Byzantijnse periode en de middeleeuwen. In een volgend stadium slagen kunstenaars erin de geometrische ruimte rationeel en coherent weer te geven met behulp van een euclidische ruimte-opvatting (die niet a priori gegeven is, maar aangeleerd). Dit is het perspectief van de renaissance, dat gebaseerd is op het statische gezichtspunt van één waarnemer, die tegenover de wereld staat en de zintuiglijk waarneembare wereld in een coördinatensysteem organiseert. In het huidige, 'formeel-operationele stadium' wordt daarentegen niet meer direct naar de zintuiglijk waarneembare werkelijkheid verwezen. Er komen 'hypothetischdeductieve, logisch-mathematische en propositionele systemen' op, waarin 'onafhankelijke relationele entiteiten zonder verwijzing naar de empirische realiteit' een plaats vinden. Zo wordt de ruimte niet meer vanuit één punt, dat van de waarnemer, georganiseerd (bij het kubisme) en worden construerende elementen van de werkelijkheid zelf object van studie, als bij het constructivisme. 
Door kunst in zo'n ontwikkeling te begrijpen, kan Gablik duidelijk maken waarom twee vierkanten van Malevitch complexer zijn dan een in detail weergegeven oorlogsmachine van Leonardo da Vinci. ${ }^{10}$ Kunst wordt in de twintigste eeuw steeds meer reflectie op de intellectuele activiteit van de mens en op de manier van waarnemen, voelen en denken, onafhankelijk van de inhoud van die waarnemingen, gevoelens en gedachten. Deze overgang was bij De Stijl goed te bespeuren en kwam ook in Mondriaans theoretische werk naar voren, zoals in hoofdstuk 6 uiteen werd gezet. Reeds in het eerste nummer van De Stijl schreef hij dat het leven van de moderne mens zich keerde 'van het natuurlijke af: het wordt al meer en meer een abstract leven'; het 'essentieele van alle beeldende schoonheidsontroering' werd door abstractie bereikt, door 'exacte beelding van enkel verhouding".".

Gablik beschouwt de genoemde ontwikkeling, anders dan Danto (en Mondriaan), niet als een eindstadium. We kunnen niet voorzien in 'een blauwdruk voor de toekomst', zo schrijft ze, maar

since art now extends beyond objects to a series of conceptual possibilities, alternatives or speculative hypotheses, it would seem, at this point in time, to be infinitely extensible - just as on the evolutionary scale progress takes the form of an everincreasing diversity and complexity. Since reflective abstraction is potentially an infinite process, there is no need to fear the end of art. [...] Development does not end as a result of achieving structural integration: it is in the nature of open systems that integration and reintegration continue to occur as long as the system exists. ${ }^{12}$

Die laatste toevoeging is verstandig, want met eeuwigheid valt tegenwoordig niet veel meer te beginnen. Maar ervan uitgaande dat Gablik met dat systeem 'kunst' bedoelt, gaat ze in haar analyse veel te ver terug. Want de afbeeldingen van de Egyptenaren of van de Grieken speelden een zo andere rol, figureerden in een zo verschillende context, dat het van grote - aan begripsrealisme 
te wijten - naïviteit getuigt om 'kunst' als een onveranderlijk bestaand verschijnsel of systeem te zien vanaf de oudste tijden tot heden. Bovendien is er veel in te brengen tegen het toepassen van een psychologisch ontwikkelingsmodel voor individuen op de kunstgeschiedenis en tegen de veronderstelling van ontwikkelingswetten in de geschiedenis. Van belang is echter de strekking van Gabliks betoog, dat kunst zich deels analoog aan kennis ontwikkelt, deels die kennis zowel weerspiegelt als creëert. Ook bij andere kunsten valt een vergelijkbare cognitieve inhoud aan te wijzen in de vorm van sensibilisering van de waarneming, toenemende reflectie en abstractie, relativering van kenmechanismen, etcetera. Om dit aannemelijk te maken is een nauwkeuriger beeld nodig van het cognitieve gehalte van kunst, een zienswijze die niet alleen op andere kunsten van toepassing moet zijn, maar bovendien rekening houdt met de expressieve en autonome cigenschappen van kunstwerken.

Zo'n beeld kan voor een deel worden ontleend aan Nelson Goodmans Languages of Art. An Approach to a Theory of Symbols. Hierin speelt representatie van kunst een cruciale rol, alleen niet als nabootsing. Want bij representatie gaat het volgens Goodman niet om gelijkenis met, of imitatie van de werkelijkheid, maar om de verwijzing naar iets (denotation). Dat iets hoeft niet te bestaan of te hebben bestaan: een afbeelding van Pickwick of van een eenhoorn verwijst net zoals een afbeelding van Churchill dat doet, zij het op een andere manier. (Goodman spreekt hier van null denotation.) Zo is het portret van de gefingeerde Pickwick tegelijkertijd het portret van een mens: het verwijst daarmee naar een verzameling, namelijk de verzameling mensen, en die verwijzing is voorwaarde voor deze representatie. Representatie veronderstelt niet alleen denotatie, maar ook classificatie. ${ }^{13}$

Omdat representatie eerder een kwestie van classificatie dan van imitatie is, eerder van karakteriseren dan van kopiëren, is representatie geen passieve aangelegenheid. Representeren is actief vorm geven. Artistieke representatie veronderstelt verder dat nieuwe verbanden op een specifieke manier tot uitdrukking worden gebracht, dat nieuwe elementen aan verzamelingen 
worden toegevoegd of dat bekende elementen aan andere verzamelingen worden gekoppeld. Goodman haalt hier Gombrich' beroemde citaat van Constable aan, die schilderen een wetenschap noemde, 'of which pictures are but the experiments'. ${ }^{4}$ Deze experimenteel-cognitieve waarde van de kunst kwam ook bij de dichters van Vijftig sterk tot uiting, zoals bleek aan het slot van het vijfde hoofdstuk, waar Kouwenaar geciteerd werd, die schreef over 'ontdekkingen, veroveringen', over 'de exploratie van het onderbewuste' en over de tocht 'naar onbekende en toch op de een of andere manier herkenbare gebieden'. Rodenko noemde het gedicht zelfs een 'zesde zintuig' om aan te geven hoe het nog onbekende aan het bekende kon worden toegevoegd."s

Een kunstenaar maakt bij representatie vanzelfsprekend gebruik van conventies en van de traditie, maar hij of zij creëert daarbij altijd iets nieuws. In die zin werpt kunst een ander licht op de wereld en levert ze een bijdrage aan kennis van de werkelijkheid. Toen Gertrude Stein klaagde dat het portret dat Picasso van haar gemaakt had nauwelijks gelijkenis vertoonde, schijnt Picasso te hebben geantwoord dat dit niet erg was - dat zou vanzelf wel komen. ${ }^{16}$ Bepaalde eigenschappen van het uiterlijk van Stein werden kennelijk pas zichtbaar door het portret van Picasso; tegelijkertijd echter veranderde de werkelijkheid door deze nieuwe representatie. Door de ingreep van Picasso ziet men Gertrude Stein anders dan daarvoor en daarmee is zij zelf veranderd. Evenzo stelde Oscar Wilde eerder, in de dialoog 'The decay of lying' ( 1891 ) bij monde van zijn protagonist Vivian, dat de buitengewone verandering in de weersgesteldheid van Londen tijdens de laatste tien jaar geheel op het conto van 'een zekere kunststroming' te schrijven was. Daarmee doelde hij op het werk van James Whistler met zijn mistige gezichten op de Theems, dat het klimaat in de stad een ander aanzien had gegeven. ${ }^{77}$ Bij Gablik viel een vergelijkbaar tersluiks constructivisme te bespeuren in haar cognitieve benadering van kunst, zij het in de meer aanvechtbare vorm van een algemeen ontwikkelingsmodel.

Zulke overwegingen laten zien dat het 'realistische gehalte' 
van kunst heel betrekkelijk is. Verwijzingen naar de werkelijkheid worden bepaald door reeksen standaardrepresentaties die afhangen van cultuur, persoonlijke omstandigheden en tijdstip. De vraag hoe realistisch representatie is, heeft hoogstens enige betekenis in een specifieke context, zoals hierboven aan de hand van Feyerabend al geillustreerd werd. Om een ander voorbeeld te geven: Giotto wilde, toen hij de Heilige Maria in 1310 in groot formaat op een troon afbeeldde, niet beschrijven dat zij veel groter was dan de omstanders: zij was belangrijker en dat is de realiteit die in zijn tijd en in de traditie van zo'n Mariavoorstelling diende te worden uitgedrukt. Of wanneer Shakespeare King Lear in razernij laat schreeuwen tegen de achtergrond van donder en bliksem, zou het vreemd zijn om op te merken dat het wel erg toevallig is dat dit noodweer losbarst op het ogenblik dat de arme koning begint te tieren - zoals het evenmin een louter theatraal effect is, aangezien deze combinatie van onweer en razernij in de eerste plaats een binnen de Elizabethaanse theaterconventies realistische uitdrukking is van de overeenkomst tussen gebeurtenissen in macro- en microkosmos. ${ }^{18}$

In het vorige hoofdstuk is gesteld dat de kunsten zich niet beperken tot het weergeven van de werkelijkheid, maar tegelijkertijd conceptueel zijn en expressie bevatten. Op dat eerste is al uitvoerig ingegaan. Hoe een kunstwerk echter iets uit kan drukken, dus: wat expressie is, verdient nog enige aandacht. Voor deze vraag, en voor de cognitieve relevantie ervan, heeft Goodman een goed oog. Hij gebruikt voor expressie de term 'exemplificatie'. Exemplificatie is het symboliseren van iets door ernaar te verwijzen en tegelijk een aantal eigenschappen ervan te bezitten die binnen de gegeven context relevant zijn, zoals het stalenboekje van een kleermaker dit doet: de stukjes stof uit zo'n boekje verwijzen naar stoffen en komen er in een aantal relevante opzichten mee overeen, namelijk kleur, patroon, textuur, etcetera. Maar in andere opzichten niet; omvang, vorm, absoluut gewicht of waarde verschillen van de stof waarnaar ze verwijzen. Expressie is nu volgens Goodman metaforische exemplificatie, waarmee hij angeeft hoe ingewikkeld dit ver- 
schijnsel is, want metaforen verwijzen op hun beurt ook weer volgens bepaalde conventies. ${ }^{19}$

Het gaat hier niet om de exacte weergave van Goodmans epistemologische symbooltheorie, die in zijn boek meer aandacht kriigt dan de empirische gevolgen ervan voor de kunst, zodat titel en ondertitel eigenlijk van plaats hadden moeten wisselen, maar om iets anders. Hij laat zien dat een voor de kunsten zo belangrijk begrip als 'expressie' een semantische lading heeft, terwijl hij een aantal nadelen van traditionele expressietheorieën van Croce, Collingwood en Dewey weet te omzeilen. (Het probleem wie of wat iets uitdrukt of ervaart, de kunstenaar, het werk of de toehoorder, lezer of toeschouwer; welke elementen in het kunstwerk gevoelens e.d. opwekken of bevatten, hoe dat gebeurt, enz.) Goodman beargumenteert hoe symbolisering in de kunsten in de vorm van zowel representatie als expressie een bij uitstek cognitief verschijnsel is. Hoewel de klassieke dichotomie tussen de cognitieve en de emotieve dimensie, en daarmee tussen wetenschap en kunst, ons vaak heeft verhinderd dit in te zien, hangen beide soorten ervaring nauw samen. ${ }^{20}$

Goodmans exercitie maakt de cognitieve waarde van kunst zichtbaar zonder dat daarmee het zo belangrijke expressieve of emotionele bestanddeel onder tafel verdwijnt. De drijfveer achter kunst is nieuwsgierigheid, de drang om te weten; esthetische voldoening bestaat allereerst uit het opdoen van nieuwe inzichten en ervaringen, het verwerven van kennis, zij het natuurlijk niet in louter discursieve zin. Hieraan ontleent (symbolisering in de) kunst ook haar waarde,

[aan] de fijnzinnigheid van haar onderscheidingen en de adequaatheid van haar toespelingen; [aan] de manier waarop ze greep op de wereld probeert te krijgen, de wereld onderzoekt en informeert; [aan] hoe ze analyseert, sorteert, orde schept en organiseert; en [aan] hoe ze deelneemt aan het maken, manipuleren, onthouden en transformeren van kennis. Overwegingen van eenvoud en subtiliteit, kracht en precisie, reikwijdte en selectief vermogen, gewoonheid en 
het nieuwe zijn allemaal relevant en raken vaak met elkaar in conflict; een afweging hierin hangt dan af van onze interesse, onze informatie en de richting van onze nieuwsgierigbeid. ${ }^{21}$

Het is deze hele baaierd van cognitieve - dus intellectuele, sensitieve en emotionele - activiteiten die in de kunsten in praktijk wordt gebracht en die vooruitgang in de verschillende kunsten mogelijk maakt. En niet alleen mogelijk maakt, maar ook, juist door dit kenniskarakter, garandeert.

De aanspraak op een dergelijke vooruitgang in de kunsten wordt misschien overtuigender wanneer er in deze pluriforme en veelomvattende cognitieve ervaringen enige orde wordt aangebracht. Daartoe kan men zich afvragen welke verdiensten of functies aan de kunst zijn toe te schrijven. Sommigen mogen dat triviaal vinden, anderen misschien zelfs ongeoorloofd door de veronderstelde belangeloosheid van de kunst, die zich in de traditie van het estheticisme aan dergelijke vragen onttrekt. Toch zijn dat wat te gemakkelijke, respectievelijk wat naïeve stellingen, hetgeen mag blijken uit het onderstaande, dat ten dele Goodman volgt.

In de eerste plaats kunnen de kunsten gezien worden als een oefening van onze symbolische vermogens, een training die ons beter in staat stelt om contingentie, dus onverwachte situaties van allerlei aard, het hoofd te bieden. Een soort gymnastiek noemt Goodman het, met schilderijen en symfonieën als halters en boksballen, waarmee we onze 'intellectuele spieren' sterker maken. ${ }^{22}$ Wie een voorbeeld wil - Goodman is daar als een echte filosoof niet erg scheutig mee - kan denken aan Luis Buñuels Le fantôme de la liberté (1974), een film die de toeschouwer een even meeslepende als duizelingwekkende reeks absurde, volstrekt onverwachte taferelen voorschotelt en hem met nieuwe ervaring de bioscoop doet verlaten. Evenzo kan de lezer van Madame Bovary een confrontatie met overspel, of met dodelijke verveling, in de werkelijkheid weliswaar nauwelijks beter verdragen, maar hij of zij zal wellicht iets minder snel door de onbekendheid ermee uit het veld zijn geslagen. Verder zal 
iemand die luistert naar J.S. Bachs fuga's en preludes uit Das wobltemperirte Clavir (1722), door sommige onverwachte of onverwacht snelle modulaties zijn verwachtingspatroon van een muzikale structuur uitbreiden (wat, om eens een echt speculatieve opmerking te maken, in principe zelfs een pendant zou kunnen hebben in een toenemende mathematische of logische flexibiliteit in het kenvermogen van de luisteraar). In moderne poëzie is deze kunstgymnastiek bijna een vanzelfsprekendheid: woorden en uitdrukkingen hebben hier een dubbelzinnige functie die steeds kleine rukjes aan de gangbare betekenissen geeft. Het begin van het destijds in Podium afgedrukte gedicht 'Het beeld' van Rodenko, geciteerd in hoofdstuk s, mag als illustratie dienen. Het gesneden beeld, 'heel licht en smaller dan een lijsterstem / een beeld van morgenrozenhout' drukt een synesthesie uit van tastzin, gezicht en gehoor en verbindt zich met een vervreemdende woordcombinatie-morgenrozenhout - die de hiervoor ontvankelijke lezer een nieuwe ervaring of sensatie kan bezorgen. Zo'n nieuwe ervaring kan ook worden opgedaan door iemand die de schilderijen van Mondriaan, Van der Leck, Huszár of Van Doesburg beschouwt: zonder mee te gaan in de verstrekkende bedoelingen van hun werk is door het bekijken ervan een grotere gevoeligheid voor vlakverdeling en kleurverhouding te ontwikkelen.

Een tweede verdienste van kunst schuilt in het al vanouds aan de kunsten toegeschreven delectare, het genot dat aan kunst als spel wordt ontleend. Zoals honden blaffen, aldus parafraseert Goodman deze optiek, zo maken mensen kunst omdat ze het niet kunnen laten en omdat het zo leuk is. Aan deze lichtvoetiger benadering ligt echter weer dezelfde cognitieve drijfveer ten grondslag, nu alleen minder in termen van heilzame oefening gesteld en meer als spontane aandrang, een nieuwsgierigheid naar nieuwe mogelijkheden binnen een aantal (vaak ongeschreven) regels en de bevrediging die mogelijkheden te hebben gevonden en gerealiseerd. Men kan denken aan de fameuze improvisatietechnieken in de jazz, van John Coltrane of Chet Baker, aan de interieurs van Van Doesburg of aan de vaak speelse poëzie van Vroman of Lucebert. De laatste dicht over een feest: 


\section{Steeds mooier}

het is zwieren met de sletpop van de rotzak stampen en zweten onder de guirlanden en je handen in het voorbijgaan afvegen aan de voorbijdansende smeerlap adeltuit heer van stonken en ronken.

In deze regels wordt een aantal nieuwe mogelijkheden van de taal gerealiseerd, zoals het letterlijk maken van het versleten scheldwoord 'smeerlap' door er iemand in het voorbijgaan de handen aan te laten afvegen. Zo'n woord wint daardoor plotseling aan kracht. Het is een miniem voorbeeld, maar in deze regels schuilen er meer en het laat zien hoe woordspelingen van een dichter de taal kunnen veranderen en dus de cognitieve rijkdom ervan kunnen vergroten. ${ }^{23}$

Een derde manier waarop de cognitieve relevantie van de kunsten zich manifesteer, L doet zich voor wanneer zewwoden beschouwd als een systeem van sociale coderingen. Talloze kunstwerken bevatten informatie en boodschappen uit een sociaal discours. Morele en culturele codes en dilemma's kunnen in de kunst vaak kernachtig worden gepropageerd of juist ter discussie worden gesteld - in films, literatuur, theater en in mindere mate in andere kunsten. Zo kreeg de waardering voor techniek en machine door het werk van De Stijl een nieuwe impuls; de vaak esthetisch geïnspireerde bezwaren tegen de ontwikkeling van een technologische cultuur werden erdoor ondermijnd. De discussies die in het afgelopen decennium in Nederland over het vermeende antisemitisme van Frans Kellendonks roman Mystiek lichaam en Fassbinders theaterstuk Het vuil, de stad en de dood werden gevoerd, zijn in het oog springende voorbeelden van een complexe maatschappelijke discussie, maar het merendeel van de naoorlogse literatuur functioneert op een vergelijkbare manier, vanaf G.K. van het Reves $D e$ avonden en Hermans' De tranen der acacia's tot op heden. In Podium viel bij de Vijftigers het antihumanisme en een nieuw soort onmaatschappelijkheid op, zoals te lezen was in Luceberts eerder afgedrukte 'School der Poëzie'. Bovendien kunnen verschillende kunsten kennis verstrekken over en begrip kweken voor de opvattingen, gebruiken en al dan niet religieuze 
vooronderstellingen van andere sociale groepen. Zo biedt The Satanic Verses van Rushdie een buitengewoon indringend beeld van sociale vermenging en verandering die met culturele integratie en confrontatie gepaard gaan, inclusief de vele problemen die zich bij verschillende vormen van wederzijdse aanpassing voordoen. In deze vormen van kunst heeft kritiek een belangrijke rol, ethisch bijvoorbeeld in het theater van Calderón of Shakespeare, politiek in dat van Brecht, om een bepaalde maatschappelijke misstand aan de orde te stellen als bij Multatuli's Max Havelaar, maatschappelijk-filosofisch als bij Sartre, moreel-historisch bij de documentaire film Shoah van Claude Lanzmann, enzovoort. Verder kan gewezen worden op het belang van discussies over het esthetisch oordeel, het argumenteren over zoiets betrekkelijks (maar voor sociale distinctie niet irrelevanntś) âls oefenining in cullturrelê ên morele debatten, het twisten over smaak als training voor het sociale verkeer en het politieke discours. ${ }^{24}$

In de laatste plaats leveren de kunsten een meer specifieke vorm van kennisverwerving op, dus niet alleen oefening van cognitieve vermogens. Voor een deel valt deze vorm met kunst als spel en met kunst als sociaal discours samen. Bedoeld wordt dat kunst mogelijkheden biedt tot symbolische opslag van kennis, het beschrijven van nieuwe psychologische ervaringen, het vastleggen van historische gebeurtenissen, verfijnde zintuiglijke gewaarwording, etcetera. Deze vorm gaat uit van het standpunt dat in de kunsten iets getoond wordt dat niet op een andere manier gezegd of beschreven kan worden. Of men hierbij aan de historische roman wil denken, aan een abstract schilderij, een gedicht, een muziekstuk, aan ballet of aan film, steeds wordt er iets getoond of met behulp van symbolen naar voren gebracht, dat niet met dezelfde nuance, precisie, eenduidigheid of juist ambivalentie had kunnen worden uitgedrukt dan wel beschreven. ${ }^{25}$ Talloze technieken en procédés, van monologue intérieur tor close-up, van muzikale computerbewerking tot pointillistische penseeltechniek, van kleurmanipulatie bij videokunst tot rijmloze sonnetten bieden de mogelijkheid om specifieke kennis op te doen of op een nieuwe manier te organiseren. 
Hoewel kunst niet uitsluitend een cognitief verschijnsel is, laat het bovenstaande zien hoe veelomvattend het cognitieve gehalte in de verschillende kunsten is. Cognitieve vooruitgang kan in talloze variaties voorkomen, per kunsttak met andere accenten en mogelijkheden, als een verrijking van de werkelijkheid. Er wordt ook geillustreerd hoe ingewikkeld dit is. Want waar kennis normaal gesproken, en zeker in een filosofische context, als een samenhangend fenomeen wordt beschouwd, lijkt de cognitieve toevoeging die aan de kunsten te danken is zich juist aan die systematiek te onttrekken. Niet zozeer volgens de simplificerende dichotomie van het verstandelijke tegenover het emotionele, maar eerder als tegengesteld aan het even klassieke clara et distincta. Op het moment dat kennis goed te lokaliseren is, en zich in een systeem laat onderbrengen of zich op een wetenschappelijke manier afdoende laat beschrijven, is zij voor de kunst niet meer van belang. Vandaar de hierboven door voorbeelden nauwelijks gemaskeerde vaagheid waarmee de aard van die kennis werd omschreven, en vandaar ook dat deze voorbeelden vaak bijna net zo goed onder een andere categorie konden vallen.

Het ging er hier echter hoofdzakelijk om te laten zien hoe belangrijk het cognitieve element van kunst is en waarom hier van vooruitgang kon worden gesproken. Belangrijk is dat er duidelijkheid bestaat over de identiteit van het proces dat in termen van vooruitgang wordt geïnterpreteerd, dus over welke kunsttak(ken) het gaat en op welke periode dit proces betrekking heeft. In het eerste hoofdstuk is beredeneerd dat het zinloos is de duur van zulke processen die van enkele eeuwen te laten overschrijden en misschien is ook dat al veel, gezien het feit dat een aantal cruciale ideeën over wat kunst is, pas in de romantiek is opgekomen.

Steeds verder

De verdedigde vormen van vooruitgang in de kunst impliceren niet dat het periodiseren als vanouds kan worden gehandhaafd. 
In het vierde hoofdstuk is weliswaar betoogd dat de oorspronkelijke opzet van 'het museum van de periodisering' tot op heden nauwelijks verloochend wordt, maar de nieuw aangebouwde vleugels van dit museum bestaan tegenwoordig wel uit uiterst flexibele tentoonstellingsruimten. Dit is natuurlijk niet los te zien van de door Susan Sontag beschreven versnelling van periodes. Die steeds kortere periodes verliezen soortelijk gewicht en in zekere zin wordt aldus het hele historische tijdsbesef aangetast, dat aan de hand van Koselleck in het begin van dit boek is geschilderd.

De geschiedenis is niet voorbij, maar periodiseren lijkt zijn tijd te hebben gehad, al blijft zo'n constatering speculatief. Het valt moeilijk te ontkennen dat historische categorieën als 'vooruitgang' en 'periode' aan metafysisch gehalte hebben ingeboet, evenals het ordescheppend vermogen van het collectieve enkelvoud (Kollektivsingular) bij historische begrippen. Zo bezien speelt de Tijd een veel geringere rol dan eens, tijdens The Great Exhibition in Crystal Palace. Dit verschil is reeds te bespeuren bij De Stijl en de Beweging van Vijftig. Terwijl bij de eerste historische categorieën als tijdgeest, noodzakelijke ontwikkeling en evolutie een prominente plaats innemen, ligt bij de Vijftigers al meer het accent op het experimentele karakter van hun streven en minder op de onvermijdelijke ontwikkeling van de Wereldliteratuur.

Het spreken over vooruitgang in de kunsten mag op een historische simplificatie neerkomen, het is - zo kan inmiddels geconcludeerd worden - geen idee-fixe, niet louter een hersenschim van iemand met heimwee naar de negentiende eeuw. Deze constatering betekent allereerst een legitimatie voor vele vormen van geschiedschrijving en historiserende kunstkritiek die sinds het postmodernisme niet meer serieus genomen leken te kunnen worden. Niet dat kunst steeds mooier (steeds beter, etcetera) wordt, maar de kunsten vertonen als samenhangende processen cumulatie en continuiteit, terwijl een dergelijke ontwikkeling ook als wenselijk wordt begrepen. Wie dat wil ontkennen zou geen moeite moeten hebben met de vernietiging van bestaande kunstwerken, dan wel de kunst cognitieve 
waarde moeten ontzeggen of die in elk geval negatief moeten waarderen.

Het besef van vooruitgang makt een inhoudelijke oriëntatie op het heden mogelijk en stelt kunstenaar en beschouwer (luisteraar, kijker) in beginsel in staat om keuzes te maken te midden van een op zichzelf onbeperkt aantal mogelijkheden. Het perspectief van vooruitgang schept een patroon in de kakofonie van het nu. De vraag of een kunstwerk iets aan de geschiedenis toevoegt, is nog steeds geen zinloze vraag, zolang deze vraag tenminste verschoond blijft van modernistische pedanterie of avantgardistisch dogmatisme, die het geloof in één weg als uitgangspunt hebben genomen. Een dergelijke historiserende discriminatie van wat wel en niet kan is zelfs voorwaarde voor een bloeiende kunstpraktijk. Zonder de bedding van kritiek, zonder een in de tijd situerende, normatieve plaatsbepaling kan alles. En waar alles kan, is niets meer mogelijk.

De hier uitgesproken voorkeur voor zo'n historische oriëntatie vertoont enige overeenkomst met de in het eerste hoofdstuk bepleite middenweg tussen nominalisme en realisme in de ideeëngeschiedenis. Zoals daar het realisme van eeuwige, onveranderlijke ideeën als naïef werd afgedaan, anderzijds een radicaal nominalisme even onvruchtbaar bleek, zo is weliswaar vanaf dat vertrekpunt de speculatieve idee van eeuwige vooruitgang direct al terzijde geschoven, maar zonder dat hiermee alle gedachten over vooruitgang onder postmodern tromgeroffel als verouderd zijn verworpen. Die verwerping zou ook paradoxaal zijn omdat ze vooruitgangsnoties veronderstelt.

Vooruitgangsideeën in de kunst, de overtuiging dat de huidige kunsten zich manifesteren in de context van een niet geheel willekeurig proces, in praktijken die het toelaten dat wat gemaakt en beoordeeld wordt, in deze tijd kan worden gesitueerd, deze noties scheppen de mogelijkheid het hoofd te bieden aan een wat vermoeid geworden kunstdiscours dat zulks bij voortduring ontkent, aan het tamboereren op de posthistorische trom van het pluralisme. Dit pluralisme lijkt op het eerste gezicht een verademing te zijn, een ontsnapping aan de historische wetmatigheden waar de vooruitgangsideologie van de avant-garde de 
kunsten zo lang mee heeft opgezadeld. Verandering bestaat dan nog wel, maar niet meer het keurslijf van de historische ontwikkeling: wat rest, is het combineren en opnieuw combineren van bekende vormen. Arthur Danto's verdediging van zulk pluralisme, een tikje ironisch en daarom niet altijd even ondubbelzinnig, beroept zich op Hegels volgeling Kojève, volgens wie het einde van de geschiedenis slechts het einde betekent van de actieve rol van geschiedenis, van oorlog en van bloedige revoluties. Maar kunst, liefde en spel, alles wat de mens gelukkig maakt, zal in dit perspectief blijven bestaan. In de communistische, post-historische utopie van Marx zonder vervreemding en arbeidsdeling zal de mens 's ochtends een jager zijn, 's middags een visser en een kritische criticus in de avond. Evenzo, aldus Danto, in de huidige artistieke utopie van het pluralisme

one could be an Abstractionist in the morning, an Expressionist in the afternoon, a Photorealist in the evening - and write art criticism after dinner. ${ }^{26}$

Je kunt papieren poppetjes uitknippen 'or do what you damned please', zo luidt het in deze after dinner-filosofie. ${ }^{27}$ Het doet er kennelijk niet meer toe wat in een dergelijk klimaat van op desinteresse gebaseerde tolerantie nog gemaakt of gezegd wordt. De radicale vrijheid van dit anything goes, die uit het huidige pluralisme spreekt, heeft daarmee op de kunsten een bijna even verlammende uitwerking als het soort vrijheid waartoe we volgens Sartre veroordeeld waren.

Men kan zich neerleggen bij de post-historische paralyse, die door Danto zo kernachtig is verwoord voor de beeldende kunsten, en die zich in de meeste kunsten even hardnekkig manifesteert. Er zijn echter medicijnen tegen de vermoeidheid van een postmodern discours en een ervan is de veronderstelling van vooruitgang in de kunsten. Deze idee is tijdens de bloei van de avant-garde jarenlang een cliché geweest. Daarna is ze in de geschiedenis bijgezet, mede op theoretische gronden, al is dat, zoals boven beargumenteerd, niet terecht. Nu wordt het tijd het weer op te poetsen, niet omdat sommige clichés zinvoller zijn 
dan andere, maar omdat het een tegengif is tegen de moeizaamheid waarmee de voor velen zo grote psychologische drempel van het volgende millennium kan worden genomen.

Vooruitgang is bij uitstek een oriëntatiemiddel in het onmisbare debat over smaak. Mede door vooruitgangsideeën valt over smaak te twisten. Door pogingen om een stand van zaken in een kunst te beschrijven en deze aan het heden te relateren, door te zoeken waarom iets nu op een bepaalde manier gemaakt wordt en niet anders, wordt steekhoudende kritiek mogelijk en daarmee blijft artistieke kwaliteit gegarandeerd. Een manier van werken is nooit willekeurig en evenmin onafhankelijk van de tijd. In een discussie over de context-afhankelijkheid van begrippen stelde Wittgenstein dat eens zijdelings aan de orde. Vergelijk een begrip, zo schreef hij in Philosophical Investigations, met een manier van schilderen (a style of painting). Is deze manier van schilderen, de Egyptische bijvoorbeeld, dan arbitrair? 'Is it,' zo vroeg hij zich even retorisch af, 'a mere question of pleasing and ugly?'28

Een notie van vooruitgang is vrijwel onmisbaar voor zowel de kunstenaar als de kritiek en de beschouwer (toehoorder, lezer), onmisbaar in de zin van een kantiaanse regulatieve idee. Het geloof in vooruitgang stimuleert originaliteit en bewerkstelligt de uitvinding van nieuwe mogelijkheden. Juist het in de achttiende eeuw op de voorgrond getreden idee van de verbeeldingskracht en het door de romantiek gevoede adagium van het principieel onvoltooibare, deze eerder beschreven voor de kunst zo vruchtbare elementen vinden hun belangrijkste voertuig in historische intuities van vooruitgang.

Zulke vooruitgang heeft natuurlijk niet meer zoveel van doen met het universele, kolossale negentiende- en achttiendeeeuwse vooruitgangsbegrip, maar het lijkt te verkiezen boven de slechts schijnbaar bescheiden aanzegging van het einde van de geschiedenis, van de kunst, van de vooruitgang. Want ook hier schuilen onder de frivole presentatie van relativisme en ironie gedachten van verval en ondergang, die even drukkend werken als de ontzetting van een provinciaal die het oude Rome voor het eerst bezocht en slechts vast kon stellen dat het vol ge- 
bouwen stond die voor de eeuwigheid waren bestemd. Wat was er nog aan de wereld toe te voegen? Het beeld stamt van de bijna vergeten filosoof Ortega y Gasset, die er het tijdsbeeld tegenoverstelde van 'de vreugde en het luidruchtig gedoe van kinderen die aan de school zijn ontsnapt'. We weten niet, zo vervolgde hij deze passage uit De opstand der horden,

wat er morgen in de wereld zal gebeuren, en in het diepst van ons hart verblijdt ons dit, want dit, het onvoorziene, de onbeperkte ruimte waarin alle mogelijk he den vrijelijk kunnen ontstaan, is bet waarachtige leven, dit is de onvervalste volheid van het bestaan. 29

Men kan het betreuren of niet, maar deze woorden zijn te pathetisch geworden voor het eind van de twintigste eeuw. Wat rest is het reculer pour mieux sauter dat in dit boek heeft doorgeklonken. Een stap terug in de aanspraken die het vooruitgangsgeloof destijds maakte, bleek onvermijdelijk. Een stap vooruit bleek mogelijk door dit geloof in een beperkte, beargumenteerde vorm weer in ere te herstellen. Een stap terug omdat toenemende artistieke kwaliteit een fictie was, een sprongetje vooruit in de mogelijkheid van cognitieve groei. Die kleine danspasjes in het aangezicht van een open en onvoorspelbare toekomst mogen niet veel betekenen, ze vertonen ten minste beweging ten opzichte van de zelfgenoegzaam aandoende rust die met het hegeliaanse finalisme en het relativerende postmodernisme in de kunsten lijkt te zijn ingetreden. 



\title{
Noten
}

\author{
INLEIDING
}

I Beerling, 'Ter inleiding'. In: L. Wittgenstein, Filosofische onderzoekingen, Meppel 1976 (oorspr. Philosophische Untersuchungen / Philosopbical Investigations, ed. G.E.M. Anscombe, R. Rhees, Oxford 1953), p.7-22 (p.21). Vgl. P. Baker \& P.M.S. Hacker, Wittgenstein. Understanding and Meaning. An Analytical Commentary on the 'Philosophical Investigations', Oxford 1980, p.16-18. Zie bijv. M. Mandelbaum, History, Man and Reason. A Study in Nineteenth Century Thoubgt, Londen / Baltimore 1974 (1971), p.369-370; S. Pollard, The Idea of Progress, Londen 1968, P.I45-146; W. Wagar, Good Tidings. The Belief in Progress from Darwin to Marcuse, Bloomington / Londen 1972, p. I 45 e.v.

3 Gerard Reve, Zelf schrijver worden (Albert Verwey-lezingen 1985), Leiden 1986, p.78.

4 Max Horkheimer, Theodor W. Adorno, Dialektik der Aufklärung, Frankfurt am Main 1984 (1947), p.3, 205-206.

5 Arthur C. Danto, 'The End of Art'. In: The Philosophical Disenfranchisement of Art, New York 1986, p.8 I-I I s; vgl. ook het laatste opstel in dit boek: "Art, Evolution, and the Consciousness of History', p.187-210. Zie verder de 'Introduction' in zijn Beyond the Brillo Box. The Visual Arts in Post-historical Perspective, New York 1992 en het hierin opgenomen opstel 'Learning to Live with Pluralism', p.3-12 resp. $217^{-2} 3 \mathrm{r}$.

6 Danto 1986, p.86-101, vgl. p.198-200.

7 Danto 1986, p.101-104, 106-107.

8 Danto I986, p.IIo-I1 5, 204-210; Danto 1992, p.4 e.v.

\section{PERSPECTIEVEN OP VOORUITGANG: GESCHIEDENIS}

I Geciteerdin: U. Haltern, Die Londoner Weltausstellung von 1851 , Münster 1971, p.169. Zie ook M. Pieterson (red.), Het technisch Labyrint. Een maatschappijgeschiedenis van drie industriële revoiuties, Meppel / Amsterdam 1981, P.118-121, 142. 
2 Geciteerd in: Haltern, p.35 I.

3 J.B. Bury, The Idea of Progress. An Inquiry into Its Origin and Growth, New York 1955 (1932). Andere veel genoemde historische overzichten zijn: J. Baillie, The Belief in Progress, Oxford 1950; J. Delvaille, Essai sur l'histoire de l'idee de progrès, Parijs 1910 ; Morris Ginsberg, The Idea of Progress. A Revaluation, Londen 1953; R. Nisbet, History of the Idea of Progress, New York 1980; Pollard 1968; J. Ritter, 'Fortschritt'. In: idem(Hsg.), Historisches Wörterbuch der Philosophie 2, Basel / Stuttgart 1972, p.1032-1059; R.V. Sampson, Progress in the Age of Reason. The i th Century to the Present Day, Londen 1956.

4 Zie H. Butterfield, The Whig Interpretation of History, Londen 195 I (1931). Butterfield karakteriseert deze whig interpretation als 'the tendency in many historians [...] to emphasize certain principles of progress in the past and to produce a story which is the ratification if not the glorification of the present' ('Preface', p.v). Mandelbaum spreekt in dergelijke gevallen van een retrospective fallacy. Zie Mandelbaum 1974, p. I 29, 134 e.v.

5 Q. Skinner, 'Meaning and Understanding in the History of Ideas'. In: History and Theory 8 (1969), p.3-53 (7-16). Vanuit Skinners optiek valt bijvoorbeeld te betwijfelen of de door Ritter in zijn artikel 'Fortschritt' genoemde progressio admirabilis (bewonderenswaardige vooruitgang) van Cicero, die hiermee op de periode na de tirannen doelt, veel met het moderne vooruitgangsidee van doen heeft (Ritter, p.1032). Weliswaar is er verschil tussen Begriffsgeschichte, waarin een begrip als naam door de eeuwen heen gevolgd wordt - Ritter makte tenslotte een Wörterbuch - en Ideengeschichte, waarin de geschiedenis van ideeën en opvattingen centraal staat, maar de betekenis van zo'n Begriffsgeschichte stoelt uiteindelijk toch op de realistische intuïtie dat woorden verwijzen naar een bepaalde stabiele kern. Skinners kritiek is a fortiori toegesneden op Nisbets interpretatie van Griekse denkers, omdat ze bij de laatste moeiteloos tot vooruitgangsprofeten worden gebombardeerd. Zo ontdoet Nisbet Plato's onveranderlijke ideeënwereld van elk belang, pleit vervolgens en passant voor verschillende Plato-opvattingen naast elkaar en sleept ten slotte enkele losse fragmenten aan - vooral uit het derde boek van De wetten - die hem hier goed van pas komen (Nisbet, p.27-32) Vgl. verder E.R. Dodds, 'Progress in Classical Antiquity'. In: P.P. Wiener, Dictionary of the History of Ideas, Vol. 3, New York 1973, 
p.629; L. Edelstein, The Idea of Progress in Classical Antiquity, Baltimore 1967, p.102-118.

6 Skinner, p.ro. De woorden stammen uit het begin van Lovejoy's The Great Chain of Being .

7 Bury, p.37-38. Nisbet laat, om een ander voorbeeld te geven, de tegenstelling tussen de aardse en de hemelse stad in Augustinus' De Civitate Dei als motor van verandering en ontwikkeling achteloos anticiperen op het begrip 'klassenstrijd' van Marx, op Darwins struggle for life en op de dialectiek van Hegel; zie Nisbet, p. $71-72$.

8 In de discussie die op dit artikel volgde nuanceerde Skinner zijn positie. Zie voor kritiek B. Parekh \& R. Berki, 'The history of Political Ideas'. In: Journal of the History of Ideas 34 (1973), p. 163-184 en Peter L. Janssen, 'Political Thought as Traditionary Action: the Critical Response to Skinner and Pocock'. In: History and Theory 24 (1985), p.1 I 5-146. Skinner beperkte zich bovendien hoofdzakelijk tot de politieke filosofie en haar geschiedenis. I $k$ zie hier af van de vermelding van Skinners in dit verband verwarrende terminologische onderscheid in 'tekstualisme' en 'contekstualisme'. Een heldere weergave en indeling van ideeëngèschiedenis geeft R. Rorty in zijn 'The Historiography of Philosophy: Four Genres'. In: R. Rorty, J.B. Schneewind, Q. Skinner (eds.), Philosophy in History. Essays on the Historiography of Philosophy, Cambridge 1984, p.49-75.

9 Vgl. Janssen, p.144-145.

Io Q. Skinner, The Foundations of Modern Political Thought (2 volumes), Cambridge 1978 . Voor zover het beeld niet verbrokkeld is, is dit uitgerekend te danken aan globale concepten als 'de moderne staat', die vrij gemakkelijk onder een van Skinners eigen 'historische absurditeiten' kunnen worden gerekend (vgl. p.rx-x).

I I M. Foucault, De orde van het spreken, Meppel / Amsterdam 1988 (1971), p.64.

I2 Zie voor meer gedetailleerde kritiek op Foucaults ideeëngeschiedenis of 'archeologie' J.G. Merquior, De filosofie van Michel Foucault, Utrecht 1988 (oorspr. 1985), p.59-71, 77-80, 149-150.

I3 O. Brunner, W. Conze, R. Koselleck (Hrsg.), Geschichtliche Grundbegriffe, Stuttgart 1972 e.v.

14 De kritiek vanuit Skinners benadering is, om ons tot het lemma Fortschritt te beperken (Geschichtliche Grundbegriffe, Bd. 2 (1975), p.351-423, vooral relevant met betrekking tot de oudheid 
(p.353-363). In deze passage, van Chr. Meier, valt stilistisch op hoe vaak er gezegd wordt dat iets (nog) niet het geval is: 'Entsprechend hatten die Vorstellungen politischer Verbesserung vermutlich wesentlich mehr mit der Fähigkeit zu umfassender institutioneller Veränderung als mit einem allmählichen, etwa gesellschaftlichen und moralischen Verbesserungsprozeß zu tun.' (p.356-357); 'Statt einer Verzeitlichung ergab sich eine Politisierung...' (p.357); '...es sei nicht ein [...] umfassender weltbemächtigender Fortschritt [...] sondern...' (p.357); 'Das Fortschreiten ist dann nur noch Sache kleiner Kreise' (p.358); enzovoort (cursiveringen aangebracht). Ook Koselleck is niet geheel onkwetsbaar voor dit soort verwijten, bijvoorbeeld waar hij spreekt van 'Bedeutungen, die noch hinzukommen mußten, um den modernen Fortschrittsbegriff freizusetzen' (p.368), maar het zijn uitzonderingen, die zijn betoog niet fundamenteel aantasten.

is R. Koselleck, Vergangene Zukunft. Zur Semantik geschichtlicher Zeiten, Frankfurt am Main 1979, p.17-37.

I6 Koselleck 1979, p. I 2-14.

17 Voor het volgende Koselleck 1979, p.19-34, 31 5, 361-362; Koselleck 1975, p.367-371.

I 8 Koselleck 1979, p.27; vgl. P. Hazard, De crisis in het Europese denken. Europa op de drempel van de Verlichting 1680-I715, Amsterdam 1990 (oorspr. 1935), deel 2, hfdst. 2.

19 Zie hiervoor Koselleck 1979, p.126, 132 e.v., 323 e.v., 336; Koselleck 1975, p. 391-402.

20 Geciteerd in: Koselleck 1975, p.391.

21 I. Kant, Idee zu einer allgemeinen Geschichte in Weltbürgerlicher Absicht $(1784)$, Akademie-Ausgabe, T. 8, p. 26.

22 Zie hiervoor Koselleck 1979, p.47-56, 321 e.v.; Koselleck 1975 , p. $384-390$.

23 In Duitsland werd de enkelvoudige term Fortschritt weliswaar in I 754 al op een theoretische manier door de voorkritische Kant gebezigd, maar als collectief enkelvoudige term, waaronder allerlei vormen van vooruitgang kunnen worden begrepen, treedt Fortschritt pas aan het eind van de achttiende eeuw op (Koselleck 1975 , p. 38 ; vgl. Ritter, p. 1052). Het gebruik van het enkelvoud komt in een andere betekeniscontext eerder wel voor. In Engeland bijvoorbeeld reeds in de titel van John Bunyans The Pilgrim's Progress uit 1678, of bij John Donne (1572-1631), die een gedicht schreef dat 'The Progress of the Soul' heette. 
24 Koselleck 1979, p.349-375.

25 Koselleck 1979, p.339-348; Koselleck 1975, p.389, 398 e.v., 407 e.v.

26 Koselleck 1979, p.341.

27 Koselleck 1975, p.407.

28 David E. Leary, 'Michel Foucault, an Historian of the Sciences Humaines'. In: Journal of the History of the Behavioral Sciences 12 (1976), p.293 (geciteerd in: Merquior, p.143).

29 Vgl. Mandelbaum, p.42.

30 W. Wieland, 'Entwicklung, Evolution'. In: Geschichtliche Grundbegriffe, Bd. 2, p. 199-228 (207). Wielands artikel beschrijft de geschiedenis van het woord Entwicklung (en marginaal van Evolution) in vooral Duitse context tot halverwege de vorige eeuw (Marx). Voor een hedendaagse beschrijving van het ontwikkelingsbegrip zie A.W. van Haaften e.a., Ontwikkelingsfilosofie. Een onderzoek naar grondslagen van ontwikkeling en opvoeding, Muiderberg 1986, p.24-26.

31 Geciteerd in: Mandelbaum, p.81-82.

$32 \mathrm{Vgl}$. Laeyendecker, p.28-30. Voor enkele andere omschrijvingen en definities zie (naast Bury) ook Th.W. Adorno, 'Vooruitgang'. In: idem, Kritische modellen, Amsterdam 1977, p. 2 I-40 (21). (Eerder ook verschenen als: 'Fortschritt'. In: H. Kuhn, F. Wiedmann (Hrsg.), Die Philosophie und die Frage nach dem Fortschritt, München 1964, p.30-48); Baillie, p. 2; Ch. van Doren, The Idea of Progress, New York / Washington / Londen 1967, p.3; Wagar 1972 , p.3 e.v.

33 H.U. Gumbrecht, 'Modern'. In: Geschichtliche Grundbegriffe, Bd. 4 (1978), p.93-131 (126 e.v.). 'Modernisering' raakt in de jaren vijftig wetenschappelijk ingeburgerd. Zie J. Habermas, 'Das Zeitbewußtsein der Moderne und ihre Bedürfnis nach Selbstvergewisserung'. In: idem, Der Philosophische Diskurs der Moderne, Frankfurt am Main 1986, p. 10. Zie verder H.R. Jauß, 'Literarische Tradition und gegenwärtiges Bewußtsein der Modernität'. In: idem, Literaturgeschichte als Provokation, Frankfurt am Main I970, p.I I e.v.

2 VAN KLASSIEKEN EN MODERNEN:

EEN OPENING NAAR DE TOEKOMST

I R. Wellek, 'Evolution of literature'. In: P.P. Wiener (ed.), Dictionary of the History of Ideas, Vol. 2, New York 1973, p.169-174 
(169). Het betreft hier overigens geen letterlijk citaat van Aristoteles; zie diens Poetica, 1449a.

2 Vgl. E.R. Dodds, 'Progress in Classical Antiquity'. In: P.P. Wiener (ed.), Dictionary of the History of Ideas, Vol. 3, New York 1973, p.623-633 (629); Th. Munro, Evolution in the Arts, Cleveland z.j., p. 38 .

3 Ritter, p.1033; zie verder Aristoteles, Ethica Nicomachea I 7, 1098a, 20-2 $\mathrm{I}$.

4 Bury, Ch. 4 en 5; P.B.M. Blaas, Anachronisme en historisch besef. Momenten uit de ontwikkeling van het Europees historisch bewustzijn, Amsterdam 1988, p.1 I, vgl. p.20.

5 Zie voor een weergave van de Querelle naast Bury: A. Adam, Histoire de la littérature française an Xvile siècle, Parijs 1948-1956, Tome 3, p.125-131, Tome 5, p.80-84; H. Baron, 'The Querelle of the Ancients and the Moderns as a Problem for Renaissance Scholarship'. In: Journal of the History of Ideas 20 (1959), p.3-22; J. Dagen, L'histoire de l'esprit humain dans la pensée française. De Fontenelle à Condorcet, Parijs 1980, p.109-160; H. Gillot, La Querelle des Anciens et des Modernes en France, Genève 1968 (1914); Hazard r990, deel I, hfdst. 2, 'Van klassiek naar modern'; H.R. Jauß, 'Ursprung und Bedeutung der Fortschrittsidee in der Querelle des Anciens et des Modernes'. In: Kuhn, Wiedmann, p. 5 I-72 (hierna aangehaald als Jauß 1964 $\alpha$ ); idem, 'Ästhetische Normen und geschichtliche Reflexion in der "Querelle des An= ciens et des Modernes"'. In: Ch. Perrault, Parallèle des Anciens et des Modernes en ce qui regarde les arts et les sciences, München 1964, p.8-64 ('Einlèitung') (hièrna vèrmeld als Jauß r964 $\beta$ ); H. Kortum, Charles Perrault und Nicolas Boileau. Der Antike-Streit im Zeitalter der klassischen französischen Literatur, Berlijn 1966; W. Kraus, Studien zur deutschen und französischen Aufklärung, Berlijn $1963 ; \mathrm{H}$. Rigault, Histoire de la querelle des anciens et des modernes, Parijs I 8 s 6 .

6 'De goede Oudheid was altijd eerbiedwaardig, / Maar ik geloof nooit, dat zij moet worden aanbeden. / Ik zie de Ouden aan zonder door de knieën te gaan, / Ze zijn groot, dat is waar, maar mensen zoals wij.' Perrault, p.165/1. Voor de stelling dat Perraults beroemde sprookjes ook in het licht van de Querelle moeten worden gelezen, zie Jeanne Morgan, Perrault's Morals for Moderns, New York 1985.

7 Zie voor het bovenstaande en de citaten Rigault, p.1 45 e.v. Verta- 


\section{Noten}

ling: 'Men zal mij altijd als volgt te werk zien gaan: / Mijn imitatie is geen slaafsheid. / Ik gebruik alleen het idee, de techniek en de regels / Die onze leermeesters zelf vroeger in praktijk brachten.' En: 'Ik prijs haar en ik weet dat ze niet onverdienstelijk is; / Maar bij deze grote namen valt ons weinig eer te beurt.'

8 Bury, p.79 e.v., voor het eerst Rigault, p.69-76. Voor kritiek hierop Jauß $1964 \beta$, p.34, n.68.

9 'En men kan zonder voor onrechtvaardigheid te hoeven vrezen / De Eeuw van Lodewijk vergelijken met het prachtige Tijdperk van Augustus.' Perrault, p.16s / 1. Het tijdperk van keizer Augustus (27 v. Chr. - 14 n. Chr.) dient ook als maatstaf voor het zelfbewuste (of zelfgenoegzame) neo-classicisme van de eerste decennia van de achttiende eeuw in Engeland, immers (ook toen) gekarakteriseerd als de Augustan Age.

10 Perrault, p. $187,34^{0-1}, 43^{8}$ e.v. De Parallèle geeft talloze voorbeelden ter discussie.

I I 'We concluderen, als u zich erin kunt vinden, dat in alle Kunsten en in alle wetenschappen met uitzondering van de Eloquentia en de Poëzie de Modernen ver uitsteken boven de Ouden, zoals ik afdoende denk te hebben aangetoond. En laten we hier, om de lieve vrede te bewaren, met betrekking tot Eloquentia en Poëzie geen uitspraak doen, hoewel er geen enkele reden is om er in dit geval anders over te oordelen.' Geciteerd in: Jauß 1964 $\beta$, p.46-47. Het bewaren van de vrede verwijst waarschijnlijk naar de door de tachtigjarige Arnauld tot stand gebrachte wapenstilstand tussen Boileau en Perrault, die elkaar jarenlang heftig hadden bestreden, o.a. op dit punt. Zie naast Jauß (t.a.p.), H. Gillot, p.486-487; H. Kortum (passim) en H. Rigault, p.257 e.v.

I 2 'Uiteindelijk laat de hele strijd om de grootste voortreffelijkheid tussen ouden en modernen zich welbeschouwd ertoe herleiden, te weten te komen of de bomen die vroeger bij ons in de natuur voorkwamen groter waren dan die van vandaag.' Fontenelle, Entretiens sur la pluralité des mondes E Digression sur les anciens et les modernes (ed. Robert Shackleton), Oxford 1955 (I686/ 1688). Vgl. Ch. Frankel, The Faith of Reason. The Idea of Progress in the French Enlightenment, New York 1948, p.103-106.

I 3 Rigault, p.303 e.v.; Bury, p. I 20-1 23 . Voor een uitvoerige beschrijving van de Engelse Querelle: J.M. Levine, The Battle of Books, Ithaca / Londen 1991.

I4 A Full and True Account of the Battle Fought last Friday Between 
the Antient and the Modern Books in St. James's Library, Londen 1704 (maar geschreven rond 1697). In één band verschenen met $A$ Tale of a Tub. Hrsg. H.J. Real, Berlijn / New York 1978.

is Swift, p.16. Zie voor de situering van The Battle of the Books de inleiding van Real, met name p.xvII-xxxv en J. Ehrenpreis, Swift. The Man, his Works, and the Age, Londen 1962, Vol. 1, p.226-237. Ehrenpreis' opmerking (p.226) dat Swifts geschrift geen "chapter in the history of ideas' is, is juist, maar laat onverlet dat het de hardnekkige rivaliteit tussen oudheid en eigen tijd fraai weerspiegelt.

16 'Mijn eeuw had al te rare goden, / Helden, door verwaandheid verdorven, / En schandelijk gierige koningen, / Gebreken die vroeger geëerbiedigd werden.' Geciteerd in: Rigault, p.370, die overigens als verschijningsdatum van Discours sur Homère eind 1713 noemt (p.369).

17 Fontenelle, p.172.

I 8 Letterlijk zegt hij over de oudheid: 'Illa enim aetas, respectu nostri antiqua et major, respectu mundi ipsius nova et minor fuit.' I, 84 ; geciteerd in: Koselleck 1975, p.372. Vgl. Bury, p.56-58.

19 Bury, p.125. Fontenelle wordt door zijn plaats in de Querelle bij voortduring in de kledij van vooruitgangsapostel gestoken, waarna historici zich vervolgens verwonderen over het feit dat hij anders is dan hij eruitziet. Bijvoorbeeld P. Gay, The Enligbtenment. An Interpretation, Vol. r, p.3r 8; 'And yet this urbane literary man, this admirer of modernity, who anticipated the philosophes in so much of his work, was not a philosophe in his heart: he never made the leap to naturalism, whether it be the deism of Voltaire, the atheism of Holbach, or the scepticism of Hume; he remained, with the century in which he was born, a tolerant, cultivated, firmly committed Christian.'

20 A. Comte, Cours de philosophie positive, $47^{e}$ leçon. Geciteerd in: Rigault, p.56r- 562 .

21 Hazard 1990, p. 52 e.v.

22 Hiernaast dient vermeld te worden: P.O. Kristeller, "The Modern System of the Arts'. In: Journal of the History of Ideas 12 (1951), en de Samengevatte discussie over Jauß'standpunt in Kuhn, Wiedmann, p.305 e.v.

23 Voor het bovenstaande Jauß 1964 $\beta$, p.12 e.v. Jauß wijst erop dat het woord progrès in Fontenelles Digression maar één keer valt en dat verder voor processen van voor(ui)tgang perfection gebruikt 
wordt (p.16). Bij Perrault is evenmin sprake van een historisch 'vooruitgangsbewustzijn'; hij beweerde bijvoorbeeld dat de geschiedenis van de mensheid na het hoogtepunt van zijn eigen tijd weer bergafwaarts zou (kunnen) gaan. Zie H.R. Jauß, 'Literarische Tradition und gegenwärtiges Bewußtsein der Modernität'. In: Jauß 1970, p. I I-66 (3I).

24 Jauß 1964ß, p.47 e.v.

25 Perrault 1, p.138-139, geciteerd in: Jauß 1964 , p. 55 .

26 Zie voor eenzelfde overgang in het achttiende-eeuwse Duitsland H. Madland, 'Imitation to Creation: The Changing Concept of Mimesis from Bodmer and Breitinger to Lenz'. In: R. Critchfield, W. Koepke (eds.), Eighteenth-Century German Authors and Their Aesthetic Theories: Literature and the Other Arts, Columbia (S.C.) 1988, p.29-43.

27 Hazard 1990, p.365-367.

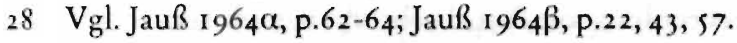

29 Voltaire, 'Le siècle de Louis XIv'. In: Oeuvres Philosophiques (ed. R. Petit), Parijs 1972, p.88, 90. Vgl. H. Vyverberg, Historical Pessimism in the French Enlightenment, Cambridge (Mass.) 1958, p.r 70 e.v.

30 Zie Wellek 1973 , p.170.

31 G.W.F. Hegel, Sämtliche Werke. Jubiläumsausgabe in zwanzig Bänden. (Hrsg. H. Glockner, Stuttgart 1927, Bd. 12, p.403-406.) Hegels periodisering in de kunst en zijn opvattingen over ontwikkeling in de kunst vormen het hoofdbestanddeel van de Vorlesungen über die Aesthetik (Bd. 12-14).

32 H.-G. Gadamer, 'Die Stellung der Poesie im System der Hegelschen Ästhetik und die Frage des Vergangenheitscharakters der Kunst'. In: A. Gethmann-Siefert und O. Pöggeler, Welt und Wirkung von Hegels Ästhetik, Hegel-Studien, Beiheft 27, Bonn 1986 , p.213-223.

33 Gadamer, p.223. Hegels bewondering voor de klassieke (Griekse) kunst, die als een variant op de bewondering voor de oudheid bij de Anciens of bij de classicist Winckelmann kan worden gezien, heeft bij de totstandkoming van zijn Ästhetik een belangrijke rol gespeeld. Daarmee lijkt al een ernstige discrepantie tussen classicistisch ideaal en de interpretatie van latere en contemporaine kunst in zijn esthetisch systeem ingebakken. Zie voor dit probleem en voor een verdediging tegen het verwijt dat Hegel poogt 'ein zum Ästhetizismus der Kunstbeurteilung verdünntes Schön- 


\section{Steeds mooier}

heitsideaal aus der griechischen Antike zu schöpfen' A. Gethmann-Siefert, Die Funktion der Kunst in der Geschichte. Untersuchungen zu Hegels Ästhetik, Hegel-Studien, Beiheft 25 , Bonn 1984 , met name p.145 e.v., 229-230, 269-270, 286 e.v. Vgl. W. Oelmüller, 'Hegels Satz vom Ende der Kunst und das Problem der Philosophie der Kunst nach Hegel'. In: Philosophisches Jabrbuch 73 (1965), p.75-94 en P. Bürger, Theorie der Avantgarde, Frankfurt am Main 1987 (1974), p.128-130.

34 Condorcet, Esquisse d'un tableau historique des progrès de l'esprit bumain, voltooid in 1793, postuum gepubliceerd in 1795 . Hier wordt geciteerd uit de editie van M. \& F. Hincker, Parijs 1971. Over progrès bij Condorcet, zie Vijverberg, p.66-71 en Ira O. Wade, The Structure and Form of the French Enlightenment, Vol. 2: Esprit Révolutionnaire, Princeton 1977, p.373-387.

35 Condorcet, p.76; vgl. p. 84 . Het enkelvoud komt in Frankrijk overigens al veel eerder voor: Pascal gebruikt het bijvoorbeeld in het voorwoord van zijn Traité du vide (1647), waarin hij voortdurende vorderingen op het gebied van kennis onderkent: '[...] tous les hommes ensemble y font un continuel progrez à mesure que l'univers vieillit'. Geciteerd in: Koselleck 1975, p.372. Vergelijk hoofdstuk 1 , noot 23.

36 Condorcet, p.77, 269; vgl. Koselleck 1975, p.377-378.

37 Condorcet, p. 129.

38 Condorcet, p.167-168, 174.

39 Condorcet, p. 245-247, 268, 276-277.

40 Condorcet, p.246. Vgl. voor dit aspect van geschichtliche Zeit ook F. Schlegel in diens kritiek op Condorcets Esquisse; Koselleck 1975, p.39I.

\section{VAN ROMANTIEK TOT AVANT-GARDE}

I R. Wellek, A History of Modern Criticism: 1750-1950, New Haven / Londen 1955 e.v., Vol. 2: The Romantic Age, 1965 (1955), p.291 $=292$.

2 Waar vaart dit schip heen? Het vaart. In daggewaad, / Naar de goddelijke en zuivere toekomst, naar de deugd, / Naar de wetenschap die men ziet gloren, / Naar het eind der plagen, naar de weldadige vergetelheid, / Naar de overvloed, naar de rust, naar het lachen, naar de gelukkige mens; / Het vaart, dit roemrijk schip, / Naar het recht, naar de rede, naar de broederschap, / Naar de ge- 


\section{Noten}

trouwe en heilige waarheid / Zonder kuiperijen en niet omsluierd, / Naar de liefde, de harten kluisterend met zachte banden, / Naar het rechtvaardige, naar het grootse, naar het goede, naar het schone... - Gij ziet / Hoe inderdaad het opklimt naar de sterren!' Victor Hugo, La légende des siècles, Parijs $1950(1859 / 1883)$, p.728-729.

3 M.H. Abrams, Natural Supernaturalism. Tradition and Revolution in Romantic Literature, New York 1971, p.62-63 (eigen vertaling).

4 Zie bijvoorbeeld Wagar 1972, p.1 8; vgl. Munro z.j., p.46.

5 Geciteerd in: Munro z.j., p.147.

6 Zie voor bovenstaande interpretatie van Comte vooral Munro z.j., p. $\{2$ e.v.; voor Comtes destijds toenemende belangstelling voor literatuur en de propangandistische rol daarvan W. Lepenies, Die drei Kulturen. Soziologie zwischen Literatur und Wissenschaft, München / Wenen 1985, p. I5-48 (m.n. 39-4r).

7 The Works of Thomas Love Peacock, ed. H. Cole, Londen I 875, 3, p.336. Geciteerd in: Murray Krieger, 'The Arts and the Idea of Progress'. In: G.A. Almond, M. Chodorow and R.H. Pearce, Progress and its Discontents, Berkeley / Los Angeles / Londen 1982 , p.449-469 (457).

8 Zie M.H. Abrams, The Mirror and the Lamp: Romantic Theory and the Critical Tradition, Oxford 1971 (1953), p.306; vgl. René Wellek, A History of Modern Criticism, Vol. 3; The Age of Transition, 1966 (1965), p. 1 26-1 27.

9 Zie voor het voorgaande Munro z.j., p.ss e.v.

10 H. Spencer, First Principles. A System of Synthetic Philosophy, Londen I 893 (1862), p.350-354 (par. 1 24), p.324-326 (par. I 14).

I I E.B. Tylor, Primitive Culture I, p.32; geciteerd in: T. Lemaire, Over de waarde van kulturen, Baarn 1976, p. 70 .

12 John Addington Symonds, Shakspeare's [sic] Predecessors in the English Drama, Londen 1884; idem, Essays Speculative and Suggestive, Londen I 890; Richard Green Moulton, Shakespeare as a Dramatic Artist, Oxford 1885 ; idem, The Modern Study of Literature, Cambridge r9rs; H.M. Posnett, Comparative Literature, Londen I 886. Zie, ook voor het volgende, Wellek I973, p.I7I e.v. en Wellek, A History of Modern Criticism:1750-1950, Vol. 4, The Late Nineteenth Century (1 966), p.58 e.v., 1 43, 297 e.v., 406 e.v.

13 Wellek, A History of Modern Criticism, Vol. 4, The Late Nineteenth Century (1966), p.27 e.v., 37-39; G. Pochat, Geschichte der 
Ästhetik und Kunsttheorie. Von der Antike bis zum 19. Jahrbundert, Keulen 1986, p.562-565.

14 Pochat, p.535-536; M. Halbertsma, "De geschiedenis van de kunstgeschiedenis in de Duitssprekende landen en Nederland van 1764 tot 1933'. In: M. Halbertsma, K. Zijlmans, Gezichtspunten. Een inleiding in de methoden van de kunstgeschiedenis, Nijmegen 1993, p.45-102 (p.5s e.v.).

is ' [...] met de hele legerschaar van satirische kwaadaardigheden op te rukken tegen de uitwassen van de historische geest, tegen het buitenproportionele zwelgen in het Proces op kosten van het bestaan en van het leven, en tegen het onbezonnen verwisselen van alle perspectieven.' Friedrich Nietzsche, Werke, Kritische Gesamtausgabe (KGw), Hrsg. G. Colli en M. Montinari, New York / Berlijn 1967 e.v.; KGW III / 1, p.239-330 (319, 314-3Is).

I6 Zie bijvoorbeeld Wagar, p.r4s e.v. Wellek ziet een betrekkelijk scherpe omslag in het begin van deze eeuw met betrekking tot de kunst: 'All over the West, the anti-historical point of view in criticism reasserted itself at about the same time.' Wellek 1973, p. 172.

17 J. Habermas 1985, p. 17; vgl. J. Habermas, 'Die Moderne - ein unvollendetes Projekt'. In: idem, Kleine politischen Schriften, Frankfurt am Main 198I, p.444-464 (p.452). Voor de (recente) geschiedenis van het begrip 'modern' zie M. Bradbury, J. McFarlane, 'The Name and Nature of Modernism'. In: idem, Modernism. A Guide to European Literature 1890-1930, Londen 1991 (1976), p.19-55; Gumbrecht 1978; H.R. Jauß, 'Literarische Tradition und gegenwärtiges Bewußtsein der Modernität'. In: idem 1970, p. I 1-60; R. Piepmeier, 'Modern, die Moderne'. In: J. Ritter, Historisches Wörterbuch der Philosophie, Bd, 6, p, \$4-62. Behandeling van theorieën over modernisme en moderniteit blijven hier buiten beschouwing. Een overzicht en vergelijking van modernisme-opvattingen bij Adorno, Derrida, Barthes e.a. is te vinden in J. Schulte-Sasse, 'Theory of Modernism versus Theory of the Avant-Garde', voorwoord bij de Engelse vertaling van Bürgers Theorie der Avantgarde, Minneapolis 1984 . Zie p.xv-xxxII. Ook het perspectief op modernisme als een Europese literaire stroming uit grofweg het interbellum, zoals beschreven door D. Fokkema en E. Ibsch in Het Modernisme in de Europese letterkunde, Amsterdam 1984, blijft hier onbesproken. Zie voor de door hen genoemde kenmerken, de 'Modernistische code', p. 10-1 I, 34-49.

18 Vgl. Gumbrecht, p.96. 
19 Geciteerd in: Jauß 1970, p.55. Zie verder p.II e.v., 54 e.v., Gumbrecht, p. I I0. Het is opmerkelijk dat Jauß hier geen verband legt met zijn enkele jaren daarvoor gemaakte onderscheid tussen het relatief en het absoluut schone, dat hij juist als een belangrijk resultaat van de Querelle des Anciens et des Modernes waardeerde.

20 Vgl. Pochat, p. 558-560.

2 I Geciteerd in: A. Hauser, Soziologie der Kunst, München 1974, p.719.

22 Geciteerd in: Gumbrecht, p. 12 1; zie verder Bradbury, MeFarlane, p.38-39.

23 M. Calinescu, " "Avant-garde": some terminological considerations'. In: Yearbook of Comparative and General Literature 23 (1974), p.67-78; F. Drijkoningen e.a., Historische avantgarde, Amsterdam 1986, p.12-13; Gumbrecht, p.122; R. Poggioli, The Theory of the Avant-Garde, New York 1968 (oorspr. Teoria dell'arte d'avanguardia, 1962), p.8-12. Het avant-gardebegrip wordt in veel literatuur aanmerkelijk breder en vager gebruikt. Zie bijv. J. Weightman, The Concept of the Avant-Garde. Explorations in Modernism, Londen 1973; Weightman plaatst het begin van de avant-garde in de verlichting en beperkt het begrip niet tot het domein van de kunst. Zie vooral p.20-37.

24 Geciteerd in: Drijkoningen e.a., p. I 8 s. Voor Bürger zie p.24 e.v., 28 e.v.

2s Hoewel Wilsons kritiek op de 'modernistische literatuur' niet een typisch avant-gardeperspectief vertegenwoordigt, verwoorden de opstellen in Axel's Castle (1931) uitvoerig het voor de avantgarde belangrijkste bezwaar tegen de artistieke traditie van de negentiende eeuw. Wilson protesteert er namelijk tegen dat de kunstenaar zich terugtrekt in een hermetisch symbolisme, of overdrachtelijk - in een kasteel waar alles voorhanden is, behalve de wereld en het echte leven, net als Axel in het gelijknamige toneelstuk van Villiers de l'Isle-Adam (1890). (Of, zo kan worden toegevoegd, in het eigen huis, zoals de zonderlinge graaf des Esseintes in J.K. Huysmans' A rebours (1884).) In dat licht is Wilsons kritiek op Dada weer verrassend; het feit dat hij Dada juist interpreteert in het verlengde van het symbolisme illustreert de tegenstrijdige interpretaties waartoe de theoretische avant-garde zich leent. Zie E. Wilson, Axels burcht. Creatieve literatuur van 1870-1930, Amsterdam 1982 (193 I). Voor kritiek op Dada vooral p. $189-190$. 
26 Bürger, p.63-72.

27 Geciteerd in: Drijkoningen e.a., p.178 resp.p.174. Vgl. p.163.

28 Octavio Paz, De kinderen van bet slijk. Van de romantiek tot de avant-garde, Amsterdam 1990 (oorspr. Los bijos del limo, 1974), p.12.

29 Bürger, p.86.

30 ibid.

\section{OVER HET MAKEN VAN REVOLUTIE}

1 Geciteerd in: M. Monnikendam, Igor Strawinsky, Haarlem 1958, p.22. Zie voor de historische achtergronden en voor de symboolwaarde van deze roemruchte avond Modris Eksteins, Lenteriten. De Eerste Wereldoorlog en bet ontstaan van de nieuwe tijd, Houten 1990 (oorspr. Rites of Spring: the Great War and the Birth of the Modern Age, Boston 1989), p.2 I-70.

2 Willem Pijper, 'Van Debussy tot heden', p.494-498. In: A. Smijers (red.), Algemene muziekgeschiedenis. Geillustreerd overzicht der Europeesche muziek van de oudheid tot heden, Utrecht 1957 , p.460-507. Vgl. Pijpers opstel over Stravinsky in De Quintencirkel, Amsterdam 1948, p. 12 e.v., waarin hij schrijft: 'Ik geloof [...] niet in het contrapunt van 1750 , niet in de harmoniek van mijn voorouders. En zeker niet als de meester die dit zegt te propageeren eertijds zelf heeft gestreden voor een edeler, want: vrijer muziek.' Zie voor een meer recente opvatting over het oeuvre van Stravinsky Mikhail Droesjkin, Igor Stravinsky. His Life, Works and Views, Cambridge I $_{98} 3$ (vert. uit het Russisch).

3 'Wie horen we daar trommelen? / Daar zullen we de kleine Modernsky hebben! / Heeft zich een pruikestaartje aan laten meten; / ziet dat er niet mooi uit! / Net echt vals haar! / Net een pruik! / Precies (net zoals de kleine Modernsky hem zich voorstelt), / precies de ouwe papa Bach!' Geciteerd in: Droesjkin, p.139-140; L. Stein, 'Schoenberg and "Kleine Modernsky"'. In: J. Pasler (ed.), Confronting Stravinsky: Man, Musician, and Modernist, Berkeley 1986, p. 310-324.

4 Th. W. Adorno, Philosophie der newen Musik, Frankfurt am Main 1958 (1948), p.1 27. Zie voor Adorno over het vooruitgangsbegrip: Adorno 1977.

5 Zie M. van Rossem, "Clement Greenberg en de strijd voor de cultuur'. In: Kunstschrift 36, (1992), nr.4, juli / augustus, p. I 5-22 (22); 


\section{Noten}

Adorno 1948 , p. 152 , resp. p. $140-141$. Mulders opstel is te vinden in E.M. Mulder, Muziek in spiegelbeeld. Essays over muziekfilosofie en dieptepsychologie, Baarn 1985, p.99-108.

6 René Wellek, Austin Warren, Theory of Literature, New York I956 (1947), p.252-269 (265).

7 Ton Anbeek, Geschiedenis van de Nederlandse literatuur 1885-1985, Amsterdam 1990, p. 13 . Anbeek verwijst hier naar het boek van Wellek en Warren (zie noot 6).

8 Thomas Kuhn, The Structure of Scientific Revolutions, Chicago 1970 (1962); idem, The Essential Tension. Selected Studies in Scientific Tradition and Change, Chicago 1977.

9 Kuhn relativeerde zijn scepsis jegens wetenschappelijke vooruitgang later in de 'Postscript - 1969', zie Kuhn 1970, p. 20 5-206.

10 R. Clignet, The Structure of Artistic Revolutions, Philadelphia 1985, p.72. Clignet ziet overigens zoveel verschillen tussen kunsten en wetenschappen en houdt steeds zoveel slagen om de arm, dat de verklarende en beschrijvende waarde van zijn boek beperkt blijft. Een andere (ten dele) op Kuhn geïnspireerde benadering is aan te treffen bij Howard S. Becker, Art Worlds, Berkeley / Los Angeles 1982, zie p.296-297, 301, 303-306, 346.

II Kuhn 1977 , p. 340-35 I. Later in dit hoofdstuk kom ik hierop terug.

12 Kuhn 1970, p.62-64; 57 e.v., 82-83.

I 3 Kuhn 1970, p.66 e.v.

I4 Nikolaus Pevsner, Pioneers of Modern Design. From William Morris to Walter Gropius, Harmondsworth 1977 (1936), p. 146. Voor de uitvinding van nieuwe technieken en theorieën in de kunst bij de totstandkoming van nieuwe paradigma's (c.q. 'art worlds') vgl. Becker, p.3 I I e.v.; Clignet, p.59-6I. In het verlengde van nieuwe technieken en procédés ligt de uitvinding van nieuwe subspecialismen en kunstgenres (fotografie, met alierlei onderverdelingen, videokunst, computermuziek, etc.); vgl. het laatste hoofdstuk van dit boek.

is Kuhn 1970, p.90, 144.

I6 Kuhn I970, p. I I I-I I s, I so. Wanneer ik het over een paradigma in de kunsten heb, ga ik uit van een pragmatische benadering: een paradigma is dan het geheel van normen en uitgangspunten dat een stroming, beweging of generatie in een of meer kunsten kenmerkt en verbindt en als zodanig vanuit een extern perspectief wordt beschouwd; niet een consistent systeem van uitspraken of 
regels. Hoewel mijn gebruik van het paradigmabegrip mede op Welleks benadering is geïnspireerd, zie ik hier af van structuralistische en semiotische implicaties.

17 Geciteerd in: Paul Rodenko, Tussen de regels. Wandelen en spoorzoeken in de moderne poëzie, Den Haag 1956, p.68, n.r.

18 Rodenko, p.66.

19 Kuhn 1970, P.152-158.

20 E.H. Gombrich, Kunst und Fortschritt. Wirkung und Wandlung einer Idee, Keulen 1978, p.116.

21 Kuhn 1977, p.350.

22 Mulder, p.106-107, vgl. p.105.

23 H. Andriessen, Over muziek, Utrecht / Antwerpen z.j. (ca. I950), p.218-219, vgl. p.92.

24 Susan Sontag, Tradities van het nieuwe of: Moeten wij modern zijn? Tehor van de achuriende Huizinga lezing, 8 december $x 9^{8} y$, Amsterdam 1990, p.8.

2s Bij wetenschap ligt dit heel anders. Afgezien van historici treffen we maar weinig wetenschappers in wetenschapsmusea aan, merkt Kuhn terecht op. 'Unlike art, science destroys its past.' Kuhn 1977, p.345-347. Vgl. Clignet p.46.

26 J. Chailley, 40.000 jaar muziek, Utrecht / Antwerpen 1967 (196I), p.144-145.

27 Vgl. Drijkoningen e.a. 1986, p.1 19, 161.

28 E.H. Gombrich, 'Stijl in kunst en stijl van leven'. In: Kunst \& Museumjournal 3, (1991), nr. 1, p.9-22 (20).

29 In tegenstelling tot wat vaak beweerd is, verschilt Mechels ordening nog aanzienliịk van de evolutionaire ordening in de schilderkunst die het negentiende-eeuwse museum aan zal brengen, zoals Debora Meijers heeft laten zien in Klasseren als principe, Amsterdam 1990. Niettemin is de aanzet tot periodisering van Mechel belangrijk.

30 Hauser 1974, p.80.

31 Hauser, p.83. Voor een overzicht van vele (hoofdzakelijk oudere, niet tot vooruitgangsideeën te herleiden) vormen van periodisering J.H.J. van der Pot, De periodisering der geschiedenis. Een overzicht der theorieën, Den Haag 1951.

32 Geciteerd in: Gombrich 1978 , p. $76-78(78)$.

33 T. Wolfe, The Painted Word, New York 1987 (1975), p.49; H. Belting, Das Ende der Kunstgeschichte?, München 1984, p. 11 .

34 P. Bourdieu, La distinction. Critique sociale du jugement, Parijs 
1979. Vgl. A. de Swaan, Kwaliteit is klasse. De sociale wording en werking van bet cultureel smaakverschil, Amsterdam 1986.

K. Mannheim, 'Die Bedeutung der Konkurrenz im Gebiete des Geistigen'. In: V. Meja, N. Stehr (Hrsg.), Der Streit um die Wissenssoziologie, Frankfurt am Main 1982, Bd.1, p.325-370 (p.330). Voor een economisch perspectief, zie H. Abbing, Een economie van de kunsten. Beschouwingen over kunst en kunstbeleid, Groningen 1989.

S VERNIEUWING IN DE POËZIE:

Podium en de Beweging van Vijftig

I Over wie nu precies tot de Vijftigers behoort kan men twisten. Hier wordt voor een losse interpretatie gekozen; vgl. Schrijversprentenboek deel 10, de beweging van viffig, (red. G. Borgers e.a.) Amsterdam 1972 (1965), p.5; R.L.K. Fokkema, Het komplot der Vijfigers, Amsterdam 1979, p.40-41. Van de Vijftiger Bert Schierbeek verscheen in 1950 proza in Podium.

2 Podium Ix: 196. In de tekst worden verder slechts jaargang en paginanummer vermeld.

3 Simon Vestdijk, Kroniek van Kunst en Kultuur 7, nr. 1, geciteerd in: Fokkema, p.ro.

4 Frank Wilders, 'Doelstelling'. In: Podium I: 54-57.

5 Fokkema, p.9, vgl. Piet Calis, Speeltuin van de titaantjes. Schrijvers en tijdschriften tussen 1945 en 1948, Amsterdam 1993, P.14 e.v.

6 Tot deze groep behoorden o.a. F.J.J. Büytendijk, M.J. Langeveld, W.P.J. Pompe en H.C. Rümke. Zie hiervoor - en voor het volgende - Ido Weijers, Terug naar bet behouden huis. Romanschrijvers en wetenschappers in de jaren vijfig, Amsterdam 1991, m.n. p.17-19. (Weijers maakt in zijn onderzoek een interessante vergelijking van de vernieuwing door de Utrechtse School met die in de romanliteratuur van na de oorlog.)

7 Daarnaast voor een historisch overzicht ook het genoemde Schrijversprentenboek deel ro, de beweging van vifftig; Anbeek, p.200-220; Siem Bakker, Het literaire tijdschrift Het Woord, 1945-1949, Amsterdam 1987, p.481-576; Calis 1993; Jan G. Elburg, Geen letterheren, Amsterdam 1987; Richter Roegholt, De geschiedenis van De Bezige Bij, Amsterdam 1972, hfdst. 4; Willemijn Stokvis, Cobra, geschiedenis, voorspel en betekenis van een 
beweging in de kunst van na de Tweede Wereldoorlog, Amsterdam 1979(1974), p.72-74, I62-164, 201-21 s.

8 G. Borgers, 'Een hand vol splinters'. In: LOSSE PLANKEN van het tienjarig Podium, Den Haag 1956, p.5. Voor de geschiedenis van het eerste decennium van Podium zie ibid., p.6-1 4; Piet Calis, Het ondergronds verwachten. Schrijvers en tijdschriften tussen 1941 en 1945, Amsterdam 1989, p.357-425; Calis 1993, p.159-398; Fokkema, p.26-37 en Richter Roegholt, p. I 54-I 55, 173-174, 176-18 I, 187-195.

9 Borgers, p.8.

10 Podium II: 55-57; zie F. Sierksma, Tandem aliquando in de polemische rubriek De proppenschieter, ibid., p.62-64 voor vergelijkbare kritiek op Het Woord. Eenzelfde (tot Forum te herleiden) strekking heeft Sierksma's 'Schoonheid als eigenbelang' in het vol-

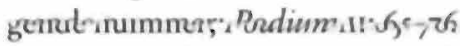

I I Voor de geschiedenis en het eind van deze twee tijdschriften zie Calis 1993 , hfdst. 1, 2 en 4 .

12 Geciteerd in: Borgers, p. I I; vgl. Calis, 1993, p.285-289. De opmerking stamt van de architect Jan Trapman (Calis 1993, p.295).

13 Nikola Petkov was leider van de Bulgaarse Boerenpartij. In juni 1947 werd hij gearresteerd en op 23 september van dat jaar geëxecuteerd. Dov Gruner was een joods verzetsleider, die in januari 1947 in Jeruzalem door de Britten ter dood werd veroordeeld en in april van dat jaar werd opgehangen.

14 Podium v: 26-41 en Podium v: 86-93. Het tweede deel is hoofdzakelijk een hier minder relevante bespreking van een boek van F.W. van Heerikhuizen. Zie voor de invloed van het verzet op Sierksma vooral de door hem geschreven 'Doelstelling' in Podium I: 4. Verder Calis 1989, p.403-408. Sierksma lijkt in de Forum-traditie de vent boven de vorm te stellen. Vgl. ook A. Wadman, 'De blinde passagier', Podium III: s 8; naast de kwaliteit van het gedicht 'blijft toch steeds die andere, klemmende vraag: wat wil die meneer?'

is Podium v: 44 I-444. Zie ook commentaar in Elburg, p.95 e.v.

I6 Podium vi: 191, Vanaf het volgende nummer treedt Sierskma "wegens gezondheidsredenen en ter voorbereiding van een proefschrift' uit de redactie terug en wordt hij vervangen door W.F. Hermans. Wel blijft hij als medewerker aan het tijdschrift verbonden. Sierksma wordt overigens later door Elburg 'een verbeten tegenstander van de experimentele ideeën' genoemd (Elburg, p. I so), wellicht ook een beetje vanwege diens vroege (en dus hard 
aankomende) veroordeling van Elburgs poëzie in Reflex.

17 Podium vi: 368-386. Rodenko had elders overigens wel reeds eerder voor een aantal veranderingen in de poëzie gepleit, dat onder de Vijftigers gemeengoed zou worden, o.a. in het Haagse tijdschrift Maecenas (november 1944) en in Columbus (december 1945). Zie Calis 1993, p.66 e.v. Volgens Piet Calis kondigden Rodenko's essays en gedichten in de eerste jaren na de oorlog de ophanden zijnde poëtische revolutie al duidelijk aan; 'Met enige overdrijving kan gezegd worden dat Rodenko soms zelfs leek op te treden als de woordvoerder van iets dat er in Nederland in feite nog niet eens was!' (Calis 1993, p.397).

18 Voor een impressie van de sfeer in het Podium van deze jaren is de lichtvoetige novelle Valentijn (1960) van Hans Andreus informatief, waarin een alter ego van de schrijver tot de redactie van het letterkundige periodiek Valreep toetreedt.

19 Vgl. Paul Rodenko, Met twee maten, Den Haag 1956, p.117.

20 Vgl. Weijers, p.28-29.

2 I Maatstaf $3, \mathrm{p} .732$; geciteerd in: Borgers, p. 13.

22 Fokkema, p.3०.

23 Vgl. Roegholt, p. 180.

24 'Reisgids in de jungle', Podium vir: 62. Atonaal verscheen in Den Haag, 195 I. Zie voor de ontstaansgeschiedenis van deze bloemlezing en de reacties erop vooral Fokkema, p. I I -140, 145, is 2-5, I 58 e.v.

25 'Experiment of gemeenplaats?', Podium virr: 206-208. Zie voor een proeve van Vinkenoogs kritisch proza dezelfde jaargang van Podium (1 $35-\mathrm{r}_{3} 8$ ), waarmee hij onbedoeld zijn stelling illustreert dat de Nederlandse poëzie serieuze kritiek ontbeert.

26 H. van Straten, 'Bij wijze van inleiding', Podium Ix: 193-196. G. Kouwenaar, 'Open p.s. aan Hans van Straten', Podium Ix: 318-332. H. van Straten, 'Vingernagels voor een nieuwe wegwijzer', Podiurn x: $5 \mathrm{r}-53$.

27 Zie bijv. Borgers e.a. p.88-89.

28 Lucebert, 'Libellecocktail', Podium x: 46-47; L.Th. Lehmann, 'Tijgers aaien', Podium x: 62-64.

29 Viff stigers, Amsterdam 1958 (1955), p.9.

30 Paul Rodenko, Nieuwe griffels/schone leien, Den Haag 1974 (1954), p.5-20. Kenmerkend voor avant-gardepoëzie is volgens Rodenko een verabsolutering van beeld en klank.

31 Viff stigers, p.7-9. In 195 I had Kouwenaar overigens wel op en- 
kele binnenlandse voorgangers gewezen (Gorter, Van Ostaijen, Achterberg); 'Pegasus heeft vleugels'. In: Kroniek van Kunst en Kultuur, dec. 1952, p.9-14 (p.11). Vgl. Rodenko in Tussen de regels. Wandelen en spoorzoeken in de moderne poëzie, Den Haag 1956, p.1 32: 'En hierin ligt de eigenlijke reden voor de weinig "revolutionaire" wijze, waarop zich de nieuwe poëzie hiertelande heeft aangediend: de jongere dichters zijn zich bewust dat zij in feite niets nieuws brengen, dat zij alleen bezig zijn een achterstand tegenover het buitenland in te halen.' Zie ook Luceberts constructie van een eigen 'voorgeschiedenis', Fokkema, p.107-108 en Anbeek, p.205.

32 Podium Ix: 193. Zie voor het volgende Podium IX: 193-196; x: \{I-53.

33 Podium vI: $370 ;$ vII: 1 ; X: 143.

2. Podium v: Aas. Hetanrogramma richtre zich in de eerste onlats on beeldende kunst, maar duidelijk niet exclusief. Er zij hier ook gewezen op het maatschappelijk engagement in de Experimentele Groep: Elburg, Kouwenaar en Lucebert blijken dan ook de meest geëngageerde (d.w.z. politiek vooruitstrevende) dichters van $V_{i j f-}$ tig, wat hun ideeën over vernieuwing kan hebben beïnvloed, die zij wellicht eerder in het kader van een proces van maatschappelijke vooruitgang plaatsen. (Lucebert spreekt in Braak (juni 1950) bijvoorbeeld van stilstand in dichterland; zie Fokkema, p.96.)

35 Fokkema, p.17-18.

36 Viffs tigers, p. 17. Zie voor een documentatie van deze uitlatingen in de eerste plaats Fokkema. Verdèr Rodenko, Tussen dè regéls; en Met iwee maten, p.89-131; Kouwenaar in de inleiding op Vijfs tigers (uitvoerig door Fokkema geciteerd); C. Buddingh', 'Aandacht voor de Avant-Garde'. In: Vandaag I, Nieuw werk van Nederlandse en Vlaamse schrijvers, Utrecht, april 1954, p.227-257 en Ad den Besten, Stroomgebied. Een inleiding tot de poëzie van de na-oorlogse dichtergeneratie, Amsterdam 1954, p.12-82.

37 Viffs tigers, p.6.

38 Bert Schierbeek, Het dier heeft een mens getekend, Amsterdam 1963 (1960), p. 123 . Braak verscheen onder redactie van Campert en Kousbroek vanaf 1950.

39 Fokkema, p.155, 159 e.v. Het idee een nieuwe generatie te zijn werd niet alleen ontleend aan gemeenschappelijke artistieke opvattingen maar minstens evenzeer aan een gedeeld levensgevoel, wat bijvoorbeeld duidelijk uit Elburgs Geen letterheren naar vo- 
ren komt. Expliciet wordt dat verwoord op p.149, 168. Een van de inhoudelijke trekken van dit levensgevoel is de twijfel aan 'zingeving' op christelijke of humanistische grondslag. Omdat deze twijfel de afgelopen decennia sterk is toegenomen, lijkt de kritiek van Ad den Besten hierop inmiddels in een veel traditioneler licht te staan dan destijds. (Zie bijvoorbeeld Den Besten, p. 78 e.v. en ook zijn later geschreven Ik ww dichter. Een boofd-stuk uit de immanente poetica van de dichters van 'so, Haarlem 1968.)

40 Fokkema, p.156.

4 I Vgl. het slot van hoofdstuk 1.

42 In deze zin is een onderneming als die van Komrij met zijn omvangrijke bloemlezingen, De Nederlandse poëzie van de ize en de I 8 e eeww in tooo en enige gedichten (Amsterdam 1986) en De Nederlandse poëzie van de r ge en de zoe eeww in 1000 en enige gedichten (A msterdam raso) nok thenreriech faerinerend, numdar hij met enig succes teruggaat in de tijd om daar het werk van de critici over te doen en zo een nieuwe geschiedenis te construeren, zoals Rodenko een voorgeschiedenis van Vijftig tracht te construeren met anthologie en geschiedschrijving.

43 Zo werpt Kouwenaar in Viff s tigers een blik achterom en stelt bijna verbaasd vast: 'Men kan er al geschiedenis over schrijven, merk ik.' (p.ro)

44 Wellek, Warren 1956 (1947); vgl. Anbeek, p.12-14.

4) Anbeek, p.14, 251.

${ }_{46}$ ibid., p.220, 269.

47 Vestdijk spreekt zelfs in zijn 'Woord vooraf' bij de bundeling van een aantal poëziekritieken uit De Gids over drie explosies, losse knallen. Simon Vestdijk, Voor en na de explosie, Ämsterdam 1980 ( 1960 ), p.7-8. Er is ook veel voor te zeggen van meer dan drie generaties te spreken en van twee (in plaats van drie) "explosies'. Zie bijvoorbeeld Anbeek, p.261, 269.

48 Viff s tigers, p.8, 17.

49 Met twee maten, p. I 1 0. Zie ook p.x 7 e.v. over het cognitieve gehalte van poëzie.

so Vgl. Maarten Doorman, 'Steeds mooier. Over vooruitgang in de kunst'. In: De Gids, 152 (1989), nr.2, p.99, $105-106$. 


\section{Steeds mooier}

\section{VERNIEUWING IN SCHILDERKUNST EN ARCHITECTUUR: DE STIJL}

I Mildred Friedman, 'Voorwoord'. In: idem (red.), De Stijl: 1917-1931, Amsterdam / Otterlo 1982 (oorspr. De Stijl 1917-1931. Visions of Utopia, Oxford 1982); p.7-9 (p.7). Zie naast dit boek voor de belangrijkste overzichtsliteratuur: Joost Baljeu, Theo van Doesburg, Londen 1974 ; Carel Blotkamp e.a., De beginjaren van De Stijl, 1917-1922, Utrecht 1982; Carel Blotkamp, Mondriaan in detail, Utrecht 1987; Rosario Crego Castaño, El Neoplasticismo y la relación elemental. Arte y estética del grupo holandés De Stijl, 1917-1931 (Tesis de Doctorado), Madrid 1990, 2 dln.; Allan Doig, Theo van Doesburg. Painting into Architecture, Theory into Practice, Cambridge 1986; H.L.C. Jaffé, De Stijl 1917-1931 - the Dutch Contribution to Modern Art, Cambridge (Mass.) / Londen / Amsterdam 1986 (oorspr. Londen 1956); idem, Theo van Doesburg, Amsterdam 1983; Serge Lemoine (dir.), Theo van Doesburg, Parijs 1990; P. Overy, De Stijl, Londen 1991; Evert van Straaten, Theo van Doesburg. Schilder en architect, Den Haag 1988; Clara Weyergraf, Piet Mondrian und Theo van Doesburg: Deutung von Werk und Theorie, München 1979; Beat Wismer, Mondrians ästhetische Utopie, Baden 1985 .

2 Jaffé 1986, p.204-208.

3 De Stijl, ie jaargang, nummer I (1917), p. I. In het vervolg wordt geciteerd uit de facsimile-uitgave De Stijl. Complete reprint, Amsterdam / Den Haag 1968 ( 2 delen; het beoogde derde deel met commentaar en vertalingen is niet verschenen).

4 Zie voor het volgende vooral Carel Blotkamp, 'Theo van Doesburg'. In: Blotkamp e.a., p.13-45 (m.n. p.17-29); Allan Doig, p.I-24, 29 e.v.; Robert P. Welsh, 'Theo van Doesburg and Geometric Abstraction'. In: Francis Bulhof (ed.), Nijhoff, Van Ostaijen, 'De Stijl'. Modernism in the Netherlands and Belgium in the First Quarter of the 2oth Century, Den Haag 1976, p.76-94.

s Jaffé 1986, p.48-49; vgl. Overy, p.55-66.

6 Vgl. Robert P. Welsh, 'De Stijl, een hernieuwde kennismaking'. In: Friedman (red.), p.17-43 (p.25). Van Doesburg had eerder overwogen het tijdschrift 'De Rechte Lijn' te noemen.

7 Crego Castaño, p.185 e.v. Vgl. Blotkamp 1987, p.20 e.v., 136 e.v.; Wismer, p.43-s2. Voor het denken van Schoenmaekers zie: Henk de Jager e.a., Het beeldende denken. Leven en werk van Mathieu 
Schoenmaekers, Baarn 1992.

8 Aan Wölfflins grote invloed op Van Doesburg in de eerste jaren van De Stijl is bij mijn weten nog weinig aandacht besteed. Zie voor Van Doesburgs kunsttheoretische voedingsbodem vooral A. Doig, p.6-23. De invloed van G.J.P.J. Bolland is inhoudelijk zowel als op het niveau van het taalgebruik vaak merkbaar in De Stijl. Zie voor relevante opvattingen van Bolland over kunst bijv. 'Aesthetische geestelijkheid'. In: idem, Zuivere rede en hare werkelijkbeid. Een boek voor vrienden der wijsheid, Leiden 1912 (oorspr. 1904), p. $541^{1-610}$. Bollands denken vertoont in sommige opzichten overigens verwantschap met het theosofisch gedachtengoed, dat hij vaak met kritische interesse bespreekt. Voor een beschrijving van Bollands invloed op De Stijl zie Crego Castaño, p.216-220.

9 Zie bijv. I:6 (1918), 68; 11:2 (1918), 1.

IO II:4 (1919), 44 e.v.; IV:I (1921), 12, I3.

11 Jaffé 1986, p.74-77, verklaart de utopische houding van De Stijl gedurende de Eerste Wereldoorlog als een reactie op de door de oorlog ontstane onzekerheid: 'Starting from the very fact that a realization of all the glorious hopes had been proved impossible in an immediate future, or at least within a measurable space and time, people tended to project their hopes into the indefinite future.' (p.76)

I 2 I: I (1917), I; zie bijvoorbeeld ook het motto van Delacroix, dat Huszár gebruikt bij de bespreking van een schilderij van Mondriaan: 'De meeste geschriften over kunst zijn vervaardigd door menschen, die geen kunstenaar zijn, vandaar al die valsche begrippen en beoordelingen.' $(\mathrm{r}: 3(\mathrm{r} 9 \mathrm{r} 8), 33)$. Mondriaan maakt een vergelijkbare opmerking (1:5 (1918), 49).

13 Zie ook Blotkamp 1982, p. I0-I I. De nummering van De Stijl verandert in deze jaargang; er wordt niet meer per jaar tot 12 genummerd, maar doorgeteld. Na vi: 12 volgt dus viI:73/ 74 (een dubbelnummer, zoals allengs vaker voorkomt vanwege het onregelmatige verschijnen. Het laatste nummer van deze jaargang, de jubileumaflevering van het tweede lustrum heet zelfs vII: $79 / 84$ ).

14 vir: $79 / 84$ (1927) (10 Jaren Stijl 1917-1927); vgl. Overy, p.43-45.

Is De Stijl I:4 (1918), 42; I:s (1918), 52 . Zie voor een beknopt en helder overzicht van Mondriaans filosofische en levensbeschouwelijke opvattingen Jaffé 1986, p. $54^{-62}$ en Els Hoek, 'Piet Mondriaan'. In: Blotkamp e.a., p.49-82 (ss e.v.). Voor hier relevante, 
uitvoeriger studies over Mondriaan Blotkamp 1987 en Wismer.

16 I:s (1918), 53. Mondriaan dankte die bijnaam aan "zijn vergeestelijkt opwaarts gerichte blik en zijn gestileerde danspassen' in het vaak door hem in een keurig zwart pak bezochte danslokaal te Laren gedurende de oorlog (Welsh 1982, p.33).

17 Cees Hilhorst, 'Bart van der Leck'. In: Blotkamp e.a., p. I55-185 (p.r6s), vgl. p.173; De Stijl I: I (1917), 6-7, vgl. ook Van der Lecks 'Over schilderen en bouwen', De Stijl I:1 (I918), 37-38.

I 8 DeStijlı:3 (1918), 25 ; deze derde aflevering heet abusievelijk nummer 4.

19 De Stijl I:s (1918), s8. In de volgende jaargang wijdt Van 't Hoff een bespreking aan de Unity Church (1909) van Frank Lloyd Wright, omdat, zo schrijft hij aan het slot, "deze architectuur de voorlooper was van de nieuwe beelding der bouwkunst welke zich aan het ontwikkelen is'. (11:4 (1918), 42)

20 Zie ook Hans Esser, 'J.J.P. Oud'. In: Blotkamp e.a., p. I 25 -I 54 ( 147 e.v.).

21 De Stijl vi:10/ I (1925), i 57-158, vgl. ook vi:8 (1924), 109-1 Io.

22 Zie Overy, p. 175 . Van Doesburg realiseerde later wel architectonische ontwerpen; het interieur van het restaurant en uitgaanscentrum l'Aubette in Straatsburg (1926-1928, met Hans Arp en Sophie Tảuber Arp; misschien toch eerder schilderkunst en vormgeving dan bouwkunst) en zijn eigen woonhuis annex atelier in Meudon (1929-1930). In deze tijd was van De Stijl als beweging echter nauwelijks meer sprake.

23 Zie voor een conflict hierover tussen Van Doesburg en Van 't Hoff Eveline Vermeulen, 'Robert van 't Hoff'. In: Blotkamp e.a., p.207-23 I (p.228-230); vgl. verder Ger Harmsen, 'De Stijl en de Russische revolutie'. In: Friedman (red.), p.45-49.

24 De Stijl I:s (1918), 50-51; de hier als * aangegeven voetnoot luidt: 'Doch dàn ook vervalt, wat we thans kunst noemen - juist omdat de subjectiveering vervalt. Dàn ontstaat een nieuwe sfeer - een nieuw leven ontstaat.'

2s Voor een helder overzicht van Mondriaans utopische ontwikkelingsdenken zie Wismer, p.59-87.

26 De Stijl I1:2 (1918), 1-2. Het manifest werd ondertekend door 'Theo van Doesburg, Robert van 't Hoff, Vilmos Huszár, Antony Kok, Piet Mondriaan, G. Vantongerloo en Jan Wils.

27 De Stijl IV:10(I92 I), 145-15 I; IV:12 (1921), 173-176. Het gaat om Daniel Henry (= Daniel-Henry Kahnweiler), Der Weg zum Ku- 


\section{Noten}

bismus, München 1920 (een uitgebreide versie van een artikel uit 1916) en M. Raynal, Picasso, München 1921 (oorspr. Parijs ca. 1920). Van Doesburg had het kubisme (en ook het futurisme en het expressionisme) anderhalf jaar eerder al eens 'voorgeboorten eener gansch nieuwe en universeele kunstconceptie' genoemd. (III:I (1919), 2)

28 'Der Wille zum Stil. (Neugestaltung von Leben, Kunst und Technik)', De Stijl v:2 (1922), 23-32; v:3 (1922), 33-41. Van Doesburg grijpt in deze stukken terug op gedachten over ontwikkeling die hij in voorafgaande jaren ook elders verkondigd had, m.n. in De nieuwe beweging in de schilderkunst (Delft 1917) en Klassiekbarok-modern (Antwerpen 1920; tegelijk verschenen in Parijs in een Franse editie). Beide geschriften zijn herdrukt in De nieuwe beweging in de schilderkunst, Amsterdam 1983, p.31-66 resp. p.III-1 26.

29 De Stijl v:2 (1922), 28. Uit het hier door Van Doesburg gehanteerde wilsbegrip spreekt wellicht ook invloed van het door de Oostenrijkse kunsthistoricus Alois Riegl geformuleerde 'Kunstwollen', het idee van een soort collectieve drijfkracht die inherent is aan elke stijlperiode.

30 Zie het eind van hoofdstuk 3 en het zevende hoofdstuk van dit boek.

3 I De Stijl vi:9 (1925), 135-136. Het stuk is anoniem, maar een Engelse versie verschijnt nog eens in de volgende jaargang (vu:73/74 (1926), 29-30) onder naam van Theo van Doesburg.

32 Geciteerd in: Hoek, p.82, vgl.p.80. Zie voor vergelijkbare opmerkingen ook Welsh 1982, p.39-40; Welsh 1976, p.90 e.v.; Overy, p.42-43. M.b.t. Mondriaans finalisme zie eveneens Wismer, p. $\$ 9$ e.v., 72 e.v.

33 De Stijl III:4 (1920), 28. Het betreft hier een bespreking van I. Goll, Die drei Guten Geister Frankreichs, Berlijn 1919.

34 Zie bijvoorbeeld ook de woedende reactie van Van Doesburg, wanneer Nederland zich op de Exposition des Arts Décoratifs van 1925 in Parijs door niemand van De Stijl laat vertegenwoordigen; 'Het fiasco van Holland op de expositie te Parijs in 1925', De Stijl vi:10/11 (1925), 156-159.

35 De Stijlv:7 (1922), 106. Van Doesburg klaagt hier ook Valori Plastici aan als een van 'de zgn: moderne Kunstperiodieken', een tot dan enigszins verwant tijdschrift, waarvan in De Stijl vele advertenties verschenen waren en dat Van Doesburg had helpen verspreiden. 


\section{Steeds mooier}

36 Zie Sjarel Ex / Els Hoek, 'Jan Wils'. In: Blotkamp e.a., p. 187-20s (200); Sjarel Ex, 'Vilmos Huszár'. In: Blotkamp e.a., p.83-124 (I 1 2); Nancy Troy, 'De abstracte leefomgeving van De Stijl'. In: Friedman (red.), p.165-189 (185).

37 De Stijl 1:1 1 (1918), 1 36; Hostes 'De roeping der moderne architectuur' staat in nr. 8 van de eerste jaargang (p. $85-87$ ); zie verder I:9 (1918), II I-I I 2 en I:I I (1918), I35-136.

38 Brief aan Van Doesburg, 21 juni 1928; ontleend aan Welsh 1982, p.40.

39 Geciteerd in: Esser, p. 136 (brief van Van Doesburg aan Oud van 13 maart 1919).

40 Blotkamp 1982, p.42-44.

41 N. Pevsner, Pioneers of Modern Design. From William Morris to Walter Gropius, Harmondsworth 1977 (oorspr. Londen 1936; laatst herziene druk Harmondsworth 1975); idem, An Outline of European Architecture, Harmondsworth 1985 (oorspr. Londen 1942); idem, A History of Building Types, Londen 1976; L. Benevolo, Storia dell'architettura moderna (2 dln.), Bari 1964. Vgl. Crego Castaño, p. 107-108.

42 Crego Castaño, p.I 12 e.v., s10-51I; Frampton 1982, p.107-109, I 1 3-I 14, I 20-1 22; Jaffé 1986, p. 177-179, 190 e.v.; Overy, p. I 56 e.v., 163 e.v., $178,198-200$.

43 Overy, p. 147. Hij beroept zich hier op Bruno Zevi en Reyner Banham. Voor Frampton zie diens Modern Architecture. A Critical History, Londen 1992 (oorspr. 1980, uitgebreid in 1985 ). Vgl. verder H.H. Arnason, A History of Modern Art, Londen $₫ 988$, p. 216 en Crego Castaño, p.343-369bis, waarin een overzicht van de esthetische vernieuwing van De Stijl in de bouwkunst.

Zie bijvoorbeeld Ernst H. Gombrich, The Story of Art, Oxford 1991 (1950); Frederick Hartt, Art. A History of Painting, Sculpture, Architecture, New York 1976; L. Hautecoeur, Histoire de l'art, Parijs 1959; Hugh Honour, John Fleming, A World History of Art, Londen 1982 ; H.W. Janson, History of Art. A Survey of the Major Visual Arts from the Dawn of History to the Present Day, New York $1962 / 1977$. Een uitzondering is Arnasons uitvoeriger en recenter A History of Modern Art; zie p.20r-205.

45 Werner Haftmann, Schilderkunst in de twintigste eeuw, Rotterdam 1965 (oorspr. Malerei im 20. Jabrbundert, München 1954), p. 147-157; Norbert Lynton, De moderne wereld. Schilderkunst, plastiek, vormgeving en architectuur der $19 e$ en $20 e$ eeuw, s.a., s.l. 


\section{Noten}

(oorspr. The Modern World, Londen 1966); idem, The Story of Modern Art, Oxford 1980; Arnason, p.201 e.v.

46 Jaffé 1956, p.202-208. Zie voor kritiek op Jaffé: Weyergraf, p.64 e.v.

47 Janson 1977, p.677, 680; E. Lucie-Smith, Movements in Art since 1945 (New revised edition), New York 1984, p.109, 174, 224.

$4^{8}$ Martin Friedman, 'Echoes of De Stijl'. In: Friedman (red.), p.207-227.

49 P. Hoenderdos, NRC Handelsblad 24-4-1981; Janson 1977, p.675.

so Bijvoorbeeld in zijn heldere In Search of Cultural History. The Philip Maurice Deneke Lecture 1967, Oxford 1969.

§1 H. Wölfflin, Stijlbegrippen in de kunstgeschiedenis, Utrecht/ Antwerpen 1960 (oorspr. 1915), p.11.

\section{HET EINDE VAN DE KUNST}

1 Robert Hughes, 'The Future that Was'. In: The Shock of the New. Art and the Century of Change, Londen 1981 (1980), Ch.8, p.365-409 (p.375). Voor een recente analyse van het eind van de avantgarde zie: D. Kuspit, The Cult of the Avant-Garde Artist, Cambridge 1993 .

2 Sontag, p.8-10, 18 e.v., 35 e.v., 4 1-49.

3 Paz 1990 (oorspr. 1974), p. I 5-16; vgl. p.1 24, 175-176.

4 Belting, p. I I.

s Zie het slot van hoofdstuk 3. Vgl. Hughes, p.385; Paz, p.30, 176; R.F. Atkinson, Knowledge and Explanation in History, Londen 1978, p.215-216.

6 Harold Rosenberg, The Tradition of the New, New York 1982 (1959), p.24.

7 Geciteerd in: R. Clignet, p.17.

8 Zie voor dit en het volgende Danto 1986, p.81-11 Is, 187-210; Danto 1992, P.3-12, 217-231.

9 Vgl. Jean-François Lyotard, 'Vorbemerkung über die Pragmatik der Werke (insbesondere zu den Werken von Daniel Buren)'. In: idem, Philosophie und Malerei im Zeitalter ihres Experimentierens, Berlijn 1986, p.79-95 en idem, 'Regeln und Paradoxa'. In: Lyotard 1986, p.97-107 (106-107).

Io Danto 1986, p.iri .

II Danto 1986, p.irs. 
I2 Danto mag zich bij zijn analyse tot de beeldende kunsten beperken, hij laat niet na er bij het begin van zijn redenering op te wijzen dat de grenzen tussen de beeldende kunsten en poëzie, opvoeringspraktijk (performance), muziek en dans steeds meer vervagen, daarmee een algemener strekking aan zijn betoog verlenend, zonder hier of elders met voorbeelden of argumenten aan te komen die deze impliciete claim zouden kunnen bevestigen. Danto I986, p.8s.

13 Danto 1986, p.89, 90, 198-199; Danto 1992, p.20, 26. Voor Gombrich zie Art and Illusion, New York 1960, p. 28-30, 89-90. Gombrich laat het mimetisch gehalte van kunst soms meer in het midden, waar hij kunst opvat als het oplossen van zelfgestelde problemen. Zie Gombrich 1978, p.89, I 14 , 1 I6. Zie voor weer een iets andere opvatting van Gombrich over representatie de eerste twee opstellen uit Meditations on a Hobby Horse and Other Essays on the Theory of Art, Londen 1963, (p.1-29) en 'The Vogue of Abstract Art'. In: idem, p. I 43-1 so. Vgl. F.R. Ankersmit, 'Historische representatie'. In: idem, De navel van de geschiedenis. Over interpretatie, representatie en historische realiteit, Groningen 1990, p.150-180 (oorspr. in: History and Theory 27 (1988), p.205-229) (p.165-167). Voor kritiek op Gombrich' opvatting over (de algemeengeldigheid) van het perspectief, zie Nelson Goodman, Languages of Art. An Approach to a Theory of Symbols, Londen 1969 (1968), p.ro e.v.; Suzi Gablik, Progress in Art, Londen I 976, p.66 e.v., I 54 e.v.

14 'Art, Evolution, and the Consciousness of History'. In: Danto 1986, p.r 87-210 (200-203). Voor een verband tussen expressie en representatie zie Goodman 1969, m.n. p.245 e.v.

is De Stijl v:3 (1922), 4 I; Theo van Doesburg, 'Het einde der kunst'. In: De Stijl vi:9 (1925), I 35-1 36, vgl. vII:73 / 74 (1926), 29-30. (Zie hoofdstuk 6.) Een vergelijkbaar argument is te vinden bij Daniel Herwitz, 'The Beginning of the End: Danto on Postmodernism'. In: Mark Rollins (ed.), Danto and bis Critics, Cambridge (Mass.) 1993, p. I 4 2- I 58 (p. I 54,156 ). Zie verder vooral Belting 1984 en Carel Blotkamp, 'Lof der schilderkunst (Crisis? What crisis?)'. In: Huttenlocher, Lasker, Van Merendonk, Rotterdam I993, p.7 I-76.

I6 Jean-Christophe Ammann, 'Jeff Koons. Ein Untergang, der keiner ist'. In: A. Muthesius (ed.), Jeff Koons, Keulen 1992, p.6-I I.

17 O. Mandelstam, 'On the Nature of the Word'. In: idem, The Complete Critical Prose and Letters (ed. J.G. Harris), Ann Arbor, Michigan 1979, p.117-132 (119). 
18 Karel van het Reve, 'Is er vooruitgang in de kunst?'. In: NRC Handelsblad 29-9-1987.

19 Wyndham Lewis, The Demon of Progress in the Arts, Londen 1954 . Voor een fraai voorbeeld van dergelijke kritiek in een kunstwerk (een installatie van Hervé Fischer uit 1979) zie Belting 1984, p. I1-12.

20 Vgl. Maarten Doorman, Vooruitgang en verval in de kunst, Wageningen 1988, p.1-4, 19-20. Vgl. ook Bas Heijne, 'Aafjes-complex'. In: idem, Heilige monsters, Amsterdam r989, p. 29-32 (oorspr. Vrij Nederland 10-9-1988).

21 Lyotard probeert dit vaker geuite verwijt te ondervangen door het postmodernisme eerder als een houding te karakteriseren dan als stroming of periode. Zie Lyotard 1986, p.97.

\section{STEEDS MEER EN STEEDS RIJKER}

I Italo Svevo, Bekentenissen van Zeno, Baarn/Amsterdam 1985 (1923), p.98.

2 Een vergelijkbaar argument met betrekking tot vooruitgang in de wetenschap, zij het met veel slagen om de arm geformuleerd, is te vinden bij Ian Hacking, 'The Accumulation of Styles of Scientific Reasoning'. In: D. Henrich (Hrsg.), Kant oder Hegel? Ueber Formen der Begrïndung in der Philosophie, Stuttgart 1983, p. 453-465.

3 Martin Seel, 'A Defense of Aesthetic Progress'. In: Praxis international, Vol. 6, no.4 (jan. 1987), p.416-425 (420-421).

4 Voor een vergelijkbare problematiek m.b.t. de verhouding tussen kwantitatieve en kwalitatieve vooruitgang zie Paul Feyerabend, 'Fortschritt in Kunst, Philosophie und Wissenschaft'. In: idem, Wissenschaft als Kunst, Frankfurt am Main 1984, p.85-106.

5 Vgl. Hauser 1974, p.86.

6 Gerrit Kouwenaar in Viff 5 tigers, Amsterdam i958 (1955), p.9.

7 Feyerabend, p.97-98. Vgl. Michael Baxandall, Painting and Experience in Fifteenth Century Italy, Oxford 1972, Part 2.

8 Gablik, p.8.

9 Gablik, p.40-90.

10 Gablik, p.43-44, vgl. p.80 e.v., 122. De schrijfster illustreert overigens onbewust hoe moeilijk de mimesis van het tweede stadium is te overwinnen: zij plaatst als reproduktie van Malevitch Twee vierkanten (1913) en een cirkel (Suprematistisch element, 1913) zo 
onder de oorlogsmachine van Da Vinci (een boogschietmachine, bestaande uit een tredmolen, een cirkel dus, en een blokvormig huisje met een schot), dat het lijkt of Malevitch toch mimetische bedoelingen moet hebben gehad (afb. 108, 109, vgl. afb. 54-58).

I De Stijl I:1 (1917), 2, 3.

I 2 Gablik, p.90, vgl. p. 166 en p.174: 'Accusations that this is an age of "cultural liquidation" because the figurative arts are in recession, the fear that art has run its course and is coming shortly to an end, have no grounds within my theory. On the contrary, I should like to dismiss out of hand the "endgame" theory of art since [...] we are just at the beginning of a new style of thinking that can generate $[\ldots]$ an indefinite array of logical systems.'

13 Goodman, p.3-10, 21-31. Voor een uitvoerig overzicht van theorieën m.b.t. representatie, betekenis, waarheid en kennis in de verschillende kunsten zie Monroe C. Beardsley, Aesthetics. Problems in the Philosophy of Criticism, Indianapolis/Cambridge 1988 (1981/1958), p.267-453.

14 Goodman, p.32-33.

is Paul Rodenko, Met twee maten, p.1 17-129 (121); Gerrit Kouwenaar, Viff, tigers, p.8, 17.

16 Goodman, p.33.

17 Oscar Wilde, 'The decay of lying' ( $189 \mathrm{r}$ ). In: idem, Selected Writings, Londen 1985 (1961).

I 8 Zie hiervoor Lily B. Campbell, Shakespeare's Tragic Heroes, Londen 1982 (1930), p.5 I e.v., $175-207$; vgl. E.M.W. Tillyard, The Elisabethan World Picture, Harmondsworth 1984 (1943), p.100-101.

19 Goodman, p. 2 e.v., 8 I-95.

20 Goodman, p. 245-2 2; 262 e.v. Vgl. S.J. Doorman, 'Bestaat vooruitgang wel in wetenschap, niet in kunst?'. In: H.W. von der Dunk e.a., De paradoxen van de vernieuwing. Het nieuwe als macht, mythe en cliché, Nijmegen 1985 , p. 5 I-64 ( $52-55)$; Thomas Munro, 'Do the Arts Progress?' In: Journal of Aesthetics and Art Criticism, Vol. 14, no.2 (december 1955), p.175-190 (185-187). Over expressie zie Beardsley 1988, p.XL-XL.II, 325 e.v. Voor kritiek op de dichotomie tussen cognitie en emotie: Heleen Pott, De liefde van Alcibiades. Over de rationaliteit van emoties, Amsterdam 1992.

21 Goodman, p.258.

22 Goodman, p.256-257.

23 Lucebert, 'het blijft feest'. In: van de roerloze woelgeest, Amsterdam 1993, p.95; Goodman, p.257, 258. 


\section{Noten}

24 S.J. Doorman, 'Enkele speculaties over kunst en wetenschap'. In: Tekens in de tijd: 65 jaar Joop den Uyl, Amsterdam 1984, p.213-237 (228-233); Goodman, p.257, 258.

$2 s$ Zie m.b.t. poëzie bijvoorbeeld Maarten Doorman, 'Over het onuitsprekelijke". In: De Gids, 1 54 (1991), nr.9, p.70 -711 .

26 Danto 1992, p.228; zie verder Danto 1986, p.85, 111-115, Danto 1992, p. 226-231.

27 Danto 1986, p.114.

28 Wittgenstein 1953, p.230; vgl. Herwitz 1993, p. 148.

29 José Ortega y Gasset, De opstand der horden, Den Haag 1962 (oorspr. La rebelión de las masas, 1930), p.70-71. 



\section{Bibliografie}

\section{Abbing, Hans}

Een economie van de kunsten. Beschowwingen over kunst en kunstbeleid, Groningen 1989.

Abrams, M.H.

Natural Supernaturalism. Tradition and Revolution in Romantic Literature, New York 1971.

Adam, A.

Histoire de la littérature française au XVIle siècle, Parijs $194^{8}$ e.v., Tomes 3, v.

Adorno, Theodor W.

Philosophie der neuen Musik, Frankfurt am Main 1958 (1948). Adorno, Theodor W.

'Vooruitgang'. In: idem, Kritische modellen, Amsterdam 1977 ,

p.21-40. (Oorspr. 'Fortschritt'. In: Stichworte. Kritische Modelle

2, Frankfurt am Main 1969, p.29-51 [1962].)

Almond, Gabriel A.; Chodorow, Marvin; Pearce, Roy Harvey

Progress and Its Discontents, Berkeley / Los Angeles / Londen 1982.

Anbeek, Ton

Geschiedenis van de Nederlandse literatuur $1885-1985$,

Amsterdam 1990, p.11-20; 200-220.

Ankersmit, F.R.

Denken over geschiedenis. Een overzicht van moderne

geschiedfilosofische opvattingen, Groningen 1986. Arx, J.P. von

Progress and Pessimism. Religion, Politics, and History in Late 19th Century Brittain, Cambridge (Mass.) / Londen $198 \mathrm{~s}$. Baillie, John

The Belief in Progress, Oxford 1951 (1950). Bakker, Siem

Het literaire tijdschrift $\mathrm{Het}$ Woord 1945-1949, Amsterdam 1987, p. $481-576$. 
Baljeu, Joost

Theo van Doesburg, Londen 1974.

Baron, Hans

'The Querelle of the Ancients and the Moderns as a Problem for Renaissance Scholarship'. In: Journal of the History of Ideas, Vol. 20 (1959), P.3-22.

Beardsley, Monroe C.

Aesthetics. Problems in the Philosophy of Criticism, Indianapolis / Cambridge 1988 (1981/1958).

Beaucamp, Eduard

Das Dilemma der Avantgarde. Aufsätze zur bildenden Kunst, Frankfurt am Main 1976.

Becker, Howard S.

Art Worlds, Berkeley / Los Angeles 1982.

Belting, Hans

Das Ende der Kunstgeschichte?, München 1984 (1983). Blaas, P.B.M.

Anachronisme en historisch besef. Momenten uit de ontwikkeling van het Europees historisch bewustzijn, Amsterdam 1988.

Blotkamp, Carel

Mondriaan in detail, Utrecht 1987.

Blotkamp, Carel; e.a.

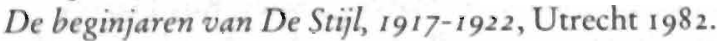

Borgers, G.; e.a. (red.)

de beweging van vijftig, Schrijversprentenboek deel 10 ,

Amsterdam 1972 (1965).

Bourdieu, P.

La distinction. Critique sociale du jugement, Parijs 1979.

Bradbury, Malcolm; McFarlane, James

Modernism. A Guide to European Literature 1890-1930,

Harmondsworth 1991 (1976).

Brunner, O.; Conze, W.; Koselleck, R. (Hrsg.)

Geschichtliche Grundbegriffe, Stuttgart 1972 e.v.

Bulhof, Francis (ed.)

Nijhoff, Van Ostaijen, 'De Stijl'. Modernism in the Netherlands and Belgium in the First Quarter of the 2oth Century, Den Haag 1976.

Burck, Erich

Die Idee des Fortschritts. Neun Vorträge über Wege und Grenzen des Fortschrittglaubens, München 1963. 


\section{Bibliografie}

\section{Bürger, Peter}

Theorie der Avantgarde, Frankfurt am Main 1987 (1974). Bury, J.B.

The Idea of Progress. An Inquiry into Its Origin and Growth,

New York 195s (1932).

Butterfield, $\mathrm{H}$.

The Whig Interpretation of History, Londen 1951 (1931).

Calis, Piet

Het ondergronds verwachten. Schrijvers en tijdschriften tussen 194I en 1945, Amsterdam 1989.

Calis, Piet

Speeltuin van de titaantjes. Schrijvers en tijdschriften tussen 1945 en 1948 , Amsterdam 1993.

Carroll, Noël

'Essence, Expression, and History: Arthur Danto's Philosophy of Art'. In: Rollins (ed.), p.79-106.

Clignet, Remi

The Structure of Artistic Revolutions, Philadelphia 1985.

Condorcet, J.A.N.C. marquis de

Esquisse d'un tableau historique des progrès de l'esprit humain

(ed. M. \& F. Hincker), Parijs 1971 (1795).

Crane, Diana

The Transformation of the Avant-garde. The New York Art

World 1940-1985, Chicago 1987.

Crego Castaño, Rosario

El Neoplasticismo y la relación elemental. Arte y estética del grupo bolandés De Stijl, 1917-1931 (Tesis de Doctorado, 2 dln.), Madrid 1990. (De handelseditie verschijnt in 1994 te Madrid.)

Critchfield, R.; Koepke, W. (eds.)

Eighteenth-Century German Autbors and Their Aesthetic

Theories: Literature and the Other Arts, Columbia (S.C.) 1988.

Dagen, J.

L'histoire de l'esprit humain dans la pensée française. De

Fontenelle à Condorcet, Parijs 1980.

Dahlhaus, Carl

Grundlagen der Musikgeschichte, Keulen 1967.

Danto, Arthur

The Philosophical Disenfranchisement of Art, New York 1986. Danto, Arthur

Beyond the Brillo Box. The Visual Arts in Post-historical

Perspective, New York 1992. 


\section{Steeds mooier}

Delvaille, Jules

Essai sur l'histoire de l'idee de progrès (jusqu'à la fin du xvine siècle), Parijs 1910.

Doig, Alan

Theo van Doesburg. Painting into Architecture, Theory into Practice, Cambridge 1986.

Doorman, Maarten

Vooruitgang en verval in de kunst, Wageningen 1988.

Doorman, Maarten

'Steeds mooier. Over vooruitgang in de kunst'. In: De Gids I 52 (1989), nr.2, februari, p.99-106.

Doorman, Maarten

‘Over het onuitsprekelijke’. In: De Gids x 54 (1991), nr.9, september, p.705-71 I.

Doorman, S.J.

'Enkele speculaties over kunst en wetenschap'. In: Tekens in de tijd: 6s jaar Joop den Uyl, Amsterdam 1984, p.213-237.

Doorman, S.J.

'Bestaat vooruitgang wel in wetenschap, niet in kunst?'. In: Von der Dunk e.a. 1985 , p. $51-64$.

Doren, Ch. van

The Idea of Progress, New York / Washington / Londen 1967.

Drijkoningen, F.; Fontijn, J. (red.)

Historische Avantgarde. Programmatische teksten van het

Italiaans futurisme, het Russisch futurisme, Dada, bet

constructivisme, bet surrealisme, bet Tsjechisch poëtisme,

Amsterdam 1986.

Dunk, H.W. von der; e.a.

De paradoxen van de vernieuwing. Het nieuwe als macht, mythe en cliché, Nijmegen 1985 .

Elburg, Jan G.

Geen letterheren, Amsterdam 1987.

Emge, C.A.

Das Problem des Fortschritts, Wiesbaden 1958.

Feyerabend, Paul

Wissenschaft als Kunst, Frankfurt am Main 1984.

Feyerabend, Paul

Farewell to Reason, Londen / New York 1987.

Fokkema, D.; Ibsch, E.

Het Modernisme in de Europese letterkunde, Amsterdam 1984. 


\section{Bibliografie}

Fokkema, R.L.K.

Het komplot der Vifftigers, Amsterdam 1979.

Fontenelle, B. de

Entretiens sur la pluralité des mondes \& Digression sur les anciens et les modernes (ed. Robert Shackleton), Oxford r95s (1686/

I688).

Foucault, Michel

De orde van het spreken, Meppel / Amsterdam 1988. (Oorspr.

L'ordre du discours, 1971.)

Friedman, Mildred (red.)

De Stijl: 1917-1931, Amsterdam / Otterlo 1982. (Oorspr. De Stijl

1917-1931. Visions of Utopia, Oxford 1982.)

Gablik, Suzi

Progress in Art, Londen 1976.

Gadamer, Hans-Georg

'Die Stellung der Poesie im System der Hegelschen Ästhetik und die Frage des Vergangenheitscharakters der Kunst'. In: A.

Gethmann-Siefert, O. Pöggeler (Hrsg.), Welt und Wirkung von Hegels Ästhetik, Hegel-Studien, Beiheft 27, Bonn 1986,

p.213-223.

Gay, Peter

'The Rise of Modern Paganism'. In: idem, The Enlightenment.

An Interpretation, Vol. I, Londen 1966, p.279-321.

Gillot, $\mathrm{H}$.

La Querelle des Anciens et des Modernes en France, Genève 1968 (1914).

Ginsberg, Morris

The Idea of Progress. A Revaluation, Londen 1953.

Gombrich, Ernst H.

Meditations on a Hobby Horse and Other Essays on the Theory

of Art, Londen 1963.

Gombrich, Ernst H.

In Search of Cultural History. The Philip Maurice Deneke

Lecture 1967 , Oxford 1969.

Gombrich, Ernst H.

Kunst und Fortschritt. Wirkung und Wandlung einer Idee,

Keulen 1978.

Gombrich, Ernst H.

'Stijl in kunst en stijl van leven'. In: Kunst \& Museumjournaal 3

(1991), nr.1, p.9-22. 
Goodman, Nelson

Languages of Art. An Approach to a Theory of Symbols, Londen 1969 (1968).

Gumbrecht, H.U.

'Modern, Modernität, Moderne'. In: Brunner, Conze, Koselleck (Hrsg.), Geschichtliche Grundbegriffe, Bd. 4 (1978), p.93-I 3 I. Haaften, A.W. van; e.a.

Ontwikkelingsfilosofie, Muiderberg 1986.

Habermas, Jürgen

'Die Moderne - ein unvollendetes Projekt'. In: idem, Kleine politischen Schriften, Frankfurt am Main 198 1, p.444-464.

Habermas, Jürgen

Der Philosophische Diskurs der Moderne. Zwölf Vorlesungen, Frankfurt am Main 1985.

Halbertsma, Marlite; Zijlmans, Kitty (red.)

Gezichtspunten. Een inleiding in de methoden van de kunstgeschiedenis, Nijmegen 1993.

Hammann, W.; Kluge, Th. (Hrsg.)

In Zukunft. Berichte über den Wandel des Fortschritts, Reinbek bei Hamburg $198 \mathrm{~s}$.

Hauser, A.

Soziologie der Kunst, München 1974.

Hazard, Paul

De crisis in bet Europese denken. Europa op de drempel van de verlichting 1680-1715, Amsterdam 1990. (Oorspr. La crise de la conscience européenne 1680-1715, 1935).

Hegel, G.W.F.

Sämtliche Werke. Jubiläumausgabe in zwanzig Bänden, Hrsg. H.

Glockner, Stuttgart 1927, Bd. 12-14.

Herwitz, Daniel

'The Beginning of the End: Danto on Postmodernism'. In:

Rollins (ed.), p.142-1 58 .

Horkheimer, Max; Adorno, Theodor W.

Dialektik der Aufklärung. Philosophische Fragmente, Frankfurt am Main 1984 (1947).

Hughes, Robert

'The Future that Was'. In: idem, The Shock of the New. Art and the Century of Change, Londen 198 I (1980).

Huizinga, J.

'De aesthetische expressie in haar verwijdering van rede en 


\section{Bibliografie}

natuur'. In: idem, In de schaduwen van morgen. Een diagnose

van bet geestelijk lijden van onzen tijd, Haarlem 1935, p.179-196. Jaffé, H.L.C.

De Stijl 1917-1931 - the Dutch Contribution to Modern Art,

Cambridge (Mass.) / Londen / Amsterdam I986 (1956). Janssen, Peter L.

'Political Thought as Traditionary Action; the Critical Response to Skinner and Pocock'. In: History and Theory 24 (1985),

p. I I s-146.

Jauß, Hans Robert

'Ursprung und Bedeutung der Fortschrittsidee in der Querelle des Anciens et des Modernes'. In: Kuhn, Wiedmann (Hrsg.),

p.5I-72. (Jauß 1964 $\alpha$.)

Jauß, Hans Robert

"Ästhetische Normen und geschichtliche Reflexion in der

"Querelle des Anciens et des Modernes" '. In: Perrault, p.8-64

('Einleitung'). (Jauß 1964ß.)

Jauß, Hans Robert

Literaturgeschichte als Provokation, Frankfurt am Main 1970. Kortum, $\mathrm{H}$.

Charles Perrault und Nicolas Boileau. Der Antike-Streit im

Zeitalter der klassischen französischen Literatur, Berlijn 1966. Koselleck, Reinhart

'Fortschritt'. In: Brunner, Conze, Koselleck (Hrsg.),

Geschichtliche Grundbegriffe, Bd. 2 (1975), p.351-423.

Koseilleck, Reinhart

Vergangene Zukunft. Zur Semantik geschichtlicher Zeiten,

Frankfurt am Main 1979.

Kraus, W.

Studien zur deutschen und französischen Aufklärung, Berlijn 1963.

Krauss, Rosalind E.

The Originality of the Avant-Garde and Other Modernist Myths, Cambridge (Mass.) 1986.

Krieger, Murray

'The Arts and the Idea of Progress'. In: Almond, Chodorow,

Pearce (eds.), p.449-469.

Kristeller, P.O.

'The Modern System of the Arts: A Study in the History of

Aesthetics'. In: Journal of the History of Ideas, Vol. I 2 (1951), 
p.496- 27 (Part I); resp. Vol. 13 (1952), p.17-46 (Part 2). Kuhn, Thomas S.

The Structure of Scientific Revolutions, Chicago 1970 (1962).

Kuhn, Thomas S.

The Essential Tension. Selected Studies in Scientific Tradition and

Change, Chicago 1977.

Kuhn, H., Wiedmann, F. (Hrsg.)

Die Philosophie und die Frage nach dem Fortschritt, München 1964.

Laeyendecker, L.

Brengt de vooruitgang ons verder? Kanttekeningen bij een wijd verbreid geloof, Baarn 1986.

Lemoine, Serge (dir.)

Theo van Doesburg, Parijs 1990.

Lepenies, W.

Die drei Kulturen. Soziologie zwischen Literatur und

Wissenschaft, München / Wenen 1985.

Levine, J.M.

The Battle of Books, Ithaca / Londen 1991.

Lewis, Wyndham

The Demon of Progress in the Arts, Londen 1954.

Löw, R.; Koslowski, P.; Kreuzer, Ph. (Hrsg.)

Fortschritt ohne Maß? Eine Ortsbestimmung der

wissenschaftlich-technischen Zivilisation, München 1981 .

Löwith, Karl

Weltgeschichte und Heilsgeschehen. Zur Kritik der

Geschichtsphilosophie, Stuttgart 1983.

Luschka, W.H.

Die Rolle des Fortschrittsgedankens in der Poetik und

literarischen Kritik der Franzosen im Zeitalter der Aufklärung,

München i 926.

Lyotard, Jean-François

Philosophie und Malerei im Zeitalter ihres Experimentierens,

Berlijn 1986.

Mandelbaum, $\mathrm{M}$.

History, Man and Reason. A Study in Nineteenth Century

Thought, Londen / Baltimore 1974 (1971).

Mannheim, Karl

'Die Bedeutung der Konkurrenz im Gebiete des Geistigen'. In:

Volker Meja, Nico Stehr (Hrsg.), Der Streit um die 


\section{Bibliografie}

Wissenssoziologie, Frankfurt am Main 1982, Bd. 1, p.325-370. Manuel, Frank E.

The Prophets of Paris, New York 1962.

Manuel, Frank E.; Manuel, Fritzie P.

Utopian Thought in the Western World, Oxford 1979.

Meijers, Debora J.

Klasseren als principe. Hoe de k.k. Bildergalerie te Wenen getransformeerd werd in een 'zichtbare geschiedenis van de kunst' (1772-1781), Amsterdam 1990.

Mulder, E.M.

'Perspectief en de dimensies der verbeelding'. In: idem, Muziek in spiegelbeeld. Essays over muziekfilosofie en dieptepsychologie, Baarn 198 s.

Munro, Thomas

'Do the Arts Progress?' In: Journal of Aesthetics and Art

Criticism, Vol. 14, no. 2 (december 1955), p.175-190.

Munro, Thomas

Evolution in the Arts, Cleveland z.j. (ca. 1964).

Nietzsche, Friedrich

'Vom Nutzen und Nächteil der Historie für das Leben'. Iñ: idem, Werke, Kritische Gesamtausgabe (KGw), Hrsg. G. Colli, M.

Montinari, New York / Berlijn 1967 e.v., KGW III/ I (1972), p.239-330 (1874).

Nisbet, Robert

History of the Idea of Progress, New York 1980.

Oelmüller, W.

'Hegels Satz vom Ende der Kunst und das Problem der

Philosophie der Kunst nach Hegel'. In: Philosophisches Jabrbuch

73 (1965), p.75-94.

Overy, P.

De Stijl, Londen $199 \mathrm{r}$.

Parekh, B.; Berki, R.

'The History of Political Ideas'. In: Journal of the History of

Ideas, 34 (1973), p.163-184.

Paz, Octavio

De kinderen van bet slijk. Van de romantiek tot de avant-garde,

Amsterdam 1990 (1976, oorspr. Los hijos del limo, 1974).

Perrault, Charles

Parallèle des Anciens et des Modernes en ce qui regarde les arts et les sciences (facsimile), München I964 (1688-1697). 
Pochat, G.

Geschichte der Ästhetik und Kunsttheorie. Von der Antike bis zum 19. Jahrhundert, Keulen 1986.

Poggioli, R.

The Theory of the Avant-Garde, New York 1968. (Oorspr.

Teoria dell'arte d'avanguardia, 1962.)

Pollard, Sidney

The Idea of Progress, Londen 1968.

Popper, Karl R.

De armoede van het historicisme, Utrecht / Antwerpen 1974.

(Oorspr. The Poverty of Historicism, 1957.)

Pot, J.H.J. van der

De periodisering der geschiedenis. Een overzicht der theorieën,

Den Haag 1951.

Rigault, Henri

Histoire de la querelle des anciens et des modernes, Parijs I 8 56. Ritter, Joachim

'Fortschritt'. In: idem, Historisches Wörterbuch der Philosophie,

Bd. 2, Basel / Stuttgart 1972, p.1032-1059.

Rochberg, George

'Can the Arts Survive Modernism? (A Discussion of the

Characteristics, History, and Legacy of Modernism)'. In: Critical

Inquiry I I (december 1984), p.317-340.

Rodenko, Paul

Tussen de regels. Wandelen en spoorzoeken in de moderne poëzie,

Den Haag 1956.

Roegholt, Richter

De geschiedenis van De Bezige Bij, Amsterdam 1972, hfdst. 4. Rollins, Mark (ed.)

Danto and his Critics, Cambridge (Mass.) 1993.

Romein, Jan

'De dialektiek van de vooruitgang' (1935). In: idem, Historische

lijnen en patronen. Een keuze wit de essays, Amsterdam 1976,

p. 40-89.

Romein, Jan

'Gedachten over de vooruitgang' (1950). In: idem, Historische

lijnen en patronen. Een keuze uit de essays, Amsterdam 1976,

p. $387-416$.

Rorty, Richard

'The Historiography of Philosophy: Four Genres'. In: R. Rorty, 


\section{Bibliografie}

J.B. Schneewind, Q. Skinner (eds.), Philosophy in History. Essays on the Historiography of Philosophy, Cambridge 1984, p.49-75.

Rosenberg, Harold

The Tradition of the New, New York 1982 (1959).

Rotenstreich, $\mathbf{N}$.

'The Idea of Historical Progress and Its Assumptions'. In:

History and Theory 10 (1971), no. 2, p.197-221.

Sampson, R.V.

Progress in the Age of Reason. The itth Century to the Present

Day, Londen 1956.

Schoot, A. van der

'Is er vooruitgang in de kunst?'. In: Caroline van Eck, Herman

Philipse (red.), Praesidium libertatis. Lezingen filosofiedag 1985 ,

Delft 1985, p.260-266.

Schulte-Sasse, Jochen

'Foreword: Theory of Modernism versus Theory of the Avant-

Garde". In: Peter Bürger, Theory of the Avant-Garde,

Minneapolis 1984 (1976), p. VII-XLVII.

Seel, Martin

'A Defense of Aesthetic Progress'. In: Praxis international, 6 (jan.

1987), no. 4, P.416-425.

Silverman, Hugh J. (ed.)

Postmodernism - Philosophy and the Arts, New York 1990.

Skinner, Quentin

'Meaning and understanding in the history of ideas'. In: History

and Theory, 8 (1969), p.3-53.

Solomon, Robert C.; Higgins, Kathleen M.

'Atomism, Art, and Arthur: Danto's Hegelian Turn'. In: Rollins (ed.), p.107-126.

Sontag, Susan

Tradities van het nieuwe of: Moeten wij modern zijn? Huizingalezing 1989, Amsterdam 1990. (Oorspr. Traditions of the New or: Must We Be Modern?)

Spencer, Herbert

First Principles. A System of Synthetic Philosophy, Londen 1893

(1862).

Staal, Frits

'Over het cyclische en het rechtlijnige tijdsbegrip'. In: idem,

Over zin en onzin in filosofie, religie en wetenschap, Amsterdam 1986, p. $51-76$. 
Stokvis, Willemijn

Cobra, geschiedenis, voorspel en betekenis van een beweging in de kunst van na de Tweede Wereldoorlog, Amsterdam 1979 (1974).

Straaten, Evert van

Theo van Doesburg. Schilder en architect, Den Haag 1988.

Swaan, A. de

Kwaliteit is klasse. De sociale wording en werking van het cultureel smaakverschil, Amsterdam 1986.

Swift, Jonathan

The Battle of the Books, Hrsg. Hermann Josef Real, Berlijn /

New York 1978 (1704).

Vyverberg, Henry

Historical Pessimism in the French Enlightenment, Cambridge (Mass.) I958.

Wade, Ira O.

The Structure and Form of the French Enlightenment, Vol. 2:

Esprit Révolutionnaire, Princeton 1977.

Wagar, W. Warren (ed.)

The Idea of Progress since the Renaissance, New York/Londen / Sydney / Toronto 1969.

Wagar, W. Warren

Good Tidings. The Belief in Progress from Darwin to Marcuse, Bloomington/Londen 1972.

Weightman, J.

The Concept of the Avant-Garde. Explorations in Modernism, Londen 1973.

Weijers, Ido

Terug naar bet behouden buis. Romanschrijvers en wetenschappers in de jaren vijftig, Amsterdam 1991.

Wellek, René

A History of Modern Criticism: 1750-1950 (8 Vols.), New Haven /Londen 1955 e.v.

Wellek, René

'Evolution of Literature'. In: P.P. Wiener (ed.), Dictionary of the History of Ideas, New York 1973, Vol. 2, p.169-174.

Wellek, René; Warren, Austin

Theory of Literature, New York I956 (1947).

Weyergraf, Clara

Piet Mondrian und Theo van Doesburg: Deutung von Werk und Theorie, München 1979. 


\section{Bibliografie}

Whittall, A.

Music since the First World War, Londen 1977.

Wieland, W.

'Entwicklung, Evolution'. In: Brunner, Conze, Koselleck

(Hrsg.), Bd.2 (1979), p.199-228.

Wismer, Beat

Mondrians ästhetische Utopie, Baden $198 \mathrm{~s}$.

Wittgenstein, Ludwig

Philosophische Untersuchungen / Philosophical Investigations, ed.

G.E.M. Anscombe, R. Rhees, Oxford 1953.

Wolfe, Tom

The Painted Word, New York 1987 (1975). 



\section{Personenregister}

Aafjes, B. $140,150$.

Abrams, M.H. 67

Achterberg, G. 128, i 311,138

Adler, G. 76

Adorno, Th.W. 12, 9I, 103, 262

Aesopus 47

Alexander de Grote 30,45

Altdorfer, A. 30

Ammann, J.-Chr. 2 I 9

Anbeek, T. 95, IS I

André, C. 213

Andreus, H. 121, 132-133, I34,

$$
\text { I 37, I40, } 141,148,232,269
$$

Andriessen, H. $\mathrm{IO}^{-}-\mathrm{IO}_{4}$

Archipenko, A. 156

Arendr, H. 12

Aristoteles 4I, 45, 230

Arnason, H.H. 199

Arnauld, A. 257

Arp, H. 197, 274

Auden, W.H. 101, 23 I

Augustinus 24, 253

Augustus 45, 257

Bach, J.S. 90, 107, 222, 229, 24I

Bach, C.Ph.E. 207

Bacon, Francis (1561-1626) 32,

\section{9}

Bacon, Francis (1909-1992) 211

Baer, K.E. von 72

Baker, Ch. 24I
Baljeu, J. 20I

Barthes, R. 262

Baudelaire, Ch. 62, 79

Beethoven, L. von 222

Belting, H. 116

Benevolo, L. 197

Bentley, R. $4^{8}$

Bergson, H. 77

Berlage, H.P. 158 , 168

Besten, A. den $133,138,140$, I 50,27 I

Blaas, P.B.M. 42

Blaman, A. 124

Blavatsky, H.P. 176

Bloem, J.C. 130,133

Boccaccio, G. 61

Bodin, J. 23, 26, 3 I

Boileau, N. 43, 44, 51, 257

Boisrobert, F. de 45

Bolland, G.J.P.J. I59, I66, 176 , 272-273

Bonset, I.K. zie Th. van

Doesburg

Boon, L.-P. 137

Borgers, G. 127, 1 29, 136, I 37,

139

Boulez, P. 2 I I

Bourdieu, P. 117

Braak, M. ter 132

Brabander, G. den 133

Braque, G. 181, 182, 185, 199 
Brecht, B. 243

Brown, J. 57

Bruner, J.S. 98-99, 123

Brunetière, F. 75

Brunner, O. 30

Bürger, P. $81,82,84-85,187,210$

Buñuel, L. 240

Bunyan, J. 254

Burch, P. van den 127,128

Burckhardt, J. 76

Burssens, G. 137

Bury, J.B. 22-25, 28, 30, $4 \mathrm{I}, 42$, 49

Butterfield, H. 252

Buytendijk, F.J.J. 267

Byron, Lord 229

Calderón de la Barca 243

Calis, P. 269 Cals, J.M.L.Th. ${ }_{13} 8$

Camini, A. zie Th. van Doesburg

Campert, R. 1 $21,122,140,141$, $145,148,149,270$

Carlisle, Lady 37

Carracci, A. 61, 228

Cervantes, M. de 207

Cézanne, P. 157, 179, I 85, 190, I9I

Chailley, J. 108

Chopin, F. 222

Chroesjtsjov, N.S. 35

Cicero 252

Cimabue I 5,42

Claus, H. 121, 132, 134, 23 I

Clignet, R. 97-98, 26 s

Cocteau, J. 169

Colin, P. I 69

Collingwood, R.G. 239

Coltrane, J. 24I

Comte, A. 23, 38, 43, 50, 58,69 ,
Condorcet, J.A.N.C., Markies de $28,33,59-62,65,66,69$, 228,260

Constable, J. 237

Conze, W. 30

Copernicus 230

Corneille, P. 45, 70

Coster, D. 128,162

Croce, B. 77, 216,239

Croiset, M. 137

Dante 6I

Danto, A. 15, 16, 19, 86, 116 , $213,214-220,224,225,229$, $233,235,247,277$

Darwin, Ch. 39, 72, 75, 253

David, J.-L. 100

Delacroix, E. 273

Derrida, J. 262

Descartes, R. $23,46,48$

Desmarets de Saint-Sorlin, J. 44, $\{2,213$

Dewey, J. 239

Dibbets, J. $20 \mathrm{I}$

Dickens, Ch. 22

Diderot, D. 191

Diels, G. ${ }^{1} 34$

Dilthey, W. 77

Djagilev, S. 89

Doesburg, Th. van 156, is7, I5 8, I59-16I, I63, I64-165, $167,168,173-174,175$, $176-179,181-186,187,188$, 189-191, 192, 193-197, 199, $217,241,272,274,275$

Domela, C. 199

Donne, J. 254

Dostojevski, F. 22

Dotremont, Chr. 125

Dubos, J.B., Abbé 53

Duiker, J. 174, I97 70-7I, 26 I 


\section{Personenregister}

Duchamp, M. 86, 92, 199, 200, 2 I 1-2 I 2, 213,233

Dyck, A. van 218

Eesteren, C. van 174

Elburg, J. 131, 132, 140, 141, $143,145,146,148,152,268$, 270

Eliot, T.S. 99, 100

Engels, F. 38

Eyck, H. van 113

Eyck, J. van II $3_{3}$

Fain, H. 28

Fassbinder, R.W. 242

Fellini, F. 2 I I

Feyerabend, P. 233, 238

Fischer, H. 278

Flaubert, G. 232

Fokkema, D.W. 95, 262

Fokkema, R.L.K. 125 , I 26, 148 Fontenelle, B. de 32, 46-47, 48, 49, 50, 55, $258-259$

Foucault, M. I 2-I 3, 28-29, 30, 37

Frampton, K. I98

Friedman, Martin 201

Friedman, Mildred I 55, 196

Fukuyama, F. 212

Gablik, S. 233-236, 237, 279

Gadamer, H.-G. 59

Galenus ${ }_{4} 8$

Galilei 98, 230

Gay, P. 258

Gehlen, A. I 2

Gezelle, G. 143

Giotto 238

Gogh, V. van I79, I8s

Goll, I. I 9 I

Gombrich, E.H. 102, 1 10, 202,
Góngora, L. de 109

Goodman, N. 21 , 236-237, 238-24I

Gorter, H. 143

Greenberg, C. 91, 202, 211

Gris, J. 199

Gropius, W. 171, 174, 194, 196-198

Gruner, D. 130,268

Guys, C. 79

Habermas, J. 12

Haftmann, W. 199

Hals, F. 6 s

Hanlo, I. 140, 141

Hauser, A. I $_{3} 3$

Hazard, P. so

Hazlitt, W. roI

Hegel, G.W.F. 16, 26, 34, 58-59, $60,69,75,82,91$, I I I, I 76 , 2 I $3,217,220,229,247,253$, 259-260

Heidegger, M. 229

Henry, D. (Daniel-Henry

Kahnweiler) I 8 I, I 82

Herakles 11, I 2, 45

Herder, J.G. 38, 58, 69

Hermans, W.F. I 24, I 27, 1 36, $137^{-1} 38,242,268$

Hijmans, W. 127

Hobbes, Th. $4^{8}$

Hoff, R. van't is $8,164,172$, $173,175,188,192,197,274$

Hölderlin, F. 229

Homerus 45, 47, 48

Hooft, P.C. 207, 231

Hoornik, E. 133

Hopper, E. 201-202

Horatius 45

Horkheimer, M. 12

Hoste, H. 194-195 
Houdar de la Motte, A. $4^{8}$

Huet, Bisschop van Soissons 44

Hughes, R. 207

Hugo, V. 66

Huszár, V. 157, 158, 160, 164 , $166,169,180,183,194,197$,

I99, 24 I, 273, 274

Huysmans, J.K. 263

Ibsch, E. 262

Jaffé, H.L.C. Is S, I57, 200, 202, 273

Janson H.W. 201

Jarrell, R. IOI

Jauß, H.R. $51-53,54,55,258$, 263

Johns, J. 213

Jonas, H. 12

Josquin des Prez 207

Joyce, J. 207, 2 I I

Judd, D. 20 I

Kalma, P. I 27

Kandinsky, W. 157, 158, 159,

$$
185,199,207
$$

Kant, I. 33, 35, 254

Kellendonk, F. 242

Kloos, W. 101

Kojève, A. 247

Kok, A. 274

Kokoschka, O. IIs

Komrij, G. 271

Koons, J. 218-219

Koselleck, R. 30-36, 37, 42, 52, $54,55,60,62,67,79,106,107$,

I1 $3,143,169,210,245,254$

Kott, J. 101

Kousbroek, R. 149, 270

Kouwenaar, G. 121, 122, 125 ,

I $31,134,139,140,141,143$,
I 45, I46, I47, I48, I49, I 50, $152,153,207,232,237,269$, 270, 271

Kugler, F. 76, I I I

Kuhn, Th. 13, 18, 96-97, 98-103, $107,115,116,117,205,206$, $221,230,265,266$

La Bruyère, J. de 44

La Fontaine, J. de 44, 51

Lamarck, J.-B.P.A. 72

Langeveld, M.J. 267

Lanzmann, C. 243

Leck, B. van der $157,158,160$, $164,168,180,182,185,194$, 199, 207, 24 I

Le Corbusier 174, 198

Léger, F. 199, 200

Lehmann, L.Th. 140

Lenin, V.I. $8 \circ$

Leonardo da Vinci 235, 279

Leopold, J.H. 143

Le Roy, L. 23

Lewis, W. 223

Le Witt, S. $20 \mathrm{I}$

Lichtenstein, R. 201, 213

Ligeti, G. 207

Ligt, B. de 196

Lodeizen, H. I 4 I

Lodewijk XIV 45, 52, 56

Lovejoy, A.O. 26

Lucanus 47

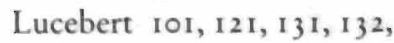
$134,135,137,140,141,143$, $144,145,146,148,152,207$, $228,232,241,242,270$

Lucie-Smith, E. 201

Lucretius 23

Lynton, N. 199

Lyotard, J.-F. 279

Macaulay, Th.B. 72 
Magritte, R. 85,92

Malevitch, K. 199, 234, 235, 279

Mallarmé, S. I81, 191

Malthus, Th.R. 72

Mandelstam, O. 221-222, 232

Manet, E. 18 ,

Marcuse, H. 12

Marsman, H. $123,127,130,138$

Marx, K. 38, 69, 247, 253

Mechel, Chr. von 111, 266

Meier, Chr. 254

Meijers, D. 266

Mendelssohn Bartholdy, F. 229

Merkelbach, B. 174,197

Messiaen, O, 222

Meyer, A. 171

Michelangelo 15,42

Miedema, P.P. 127

Mies van der Rohe, L. 198

Mill, J.S. 23,69

Mirabeau, V., Markies de 23

Molen, W.J. van der I 34

Molière 45,70

Mondriaan, P. 157-160,163, I 64, I 65-I66, I67, I68, I69, $175-176,179-181,185,186$, I 88, I 89-190, 191, I93-194, I 96, 1 98-I 99, 20I-202, 21 r, $217,229,230,234,235,24 \mathrm{I}$, $273,274,275$

Monet, C. 218

Montaigne, $\mathrm{M}$. de $3 \mathrm{I}=32$

Morgan, L.H. 39, 70

Morris, W. 99, 109, 161, 169, 196 Moulton, R.G. 75

Mozart, W.A. 222, 229, 230

Müller, A. 66

Mulder, E. 91, 103

Multatuli 243

Mumford, L. I2
Nagel, W.H. 137

Nestroy, J.N. 11, 12

Newman, B. 201,229

Newton, I. 230

Nietzsche, F. $76-77,8_{4}, 18_{3}, 220$

Nijhoff, M. 131, 133

Nisbet, R. 24-25, 252,253

Nizjinski, V. 89

Noland, K. 201

Novalis $6 \mathrm{~s}$

Opsomer, D. 137

Ortega y Gasset, J. 249

Ostaijen, P. van $134,138,145$

Oud, J.J.P. 157, 158, 163, 164 , $166-167,170,171,173,174$, $175,190,192,194,195,196$, 197

Oversteegen, J.J. 95

Overy, P. 198, 202

Panofsky, E. 216, 232

Paracelsus $4^{8}$

Pascal, B. 260

Paz, O. 83, 209

Peacock, Th.L. 71

Perikles 208

Perrault, Ch. $43,44,45-46,48$, $51,52-53,79,257,259$

Petkov, N. 130,268

Petrarca 45, 61, 231

Pevsner, N. 196-197

Piaget, J. 234

Picabia, F. 81, 199

Picasso, P. $85,91,9^{8}, 100,156$, 179, 181, 182, $185,191,194$, 199, 202, 208, 221 , 228-229, 230, 237

Pijper, W. 90, 103, 264

Pijpers, E. 176-177

Plato 220, 252 
Poesjkin, A. 229

Polet, S. 121 , 132, 134,14 I

Polke, S. 218

Pollock, J. 234

Pompe, W.P.J. 267

Popper, K. 215

Posnett, H.M. 75

Postman, L. 98-99, 123

Poussin, N. 207

Ptolemaeus 230

Quesnay, F. 23

Rafaël 61, 70, 228

Ranke, L. von 65

Raynal, M. 181,182

Rembrandt 65, 98, 185,207 , 221,230

Reve, G. (G.K. van het) 11, 124 , 136, 242

Reve, K. van het 222-223

Richter, H. 163

Rickert, H. 74

Riegl, A. 77, 275

Riemann, H. 76

Rietveld, G. 157, 163, 194, 196, 201

Rimbaud, A. 80,100

Ritter, J. 252

Rodenko, P. 101, 104, 121, 122, $128-129,132-134,136-137$, $140,141,142,143,144,145$, I 50, 153, 237, 241, 268, 269, 271

Roland Holst, A. 127, 1 32, 133 Roland Holst, R.N. 180 , 192 Rorty, R. 253

Rosenberg, H. 2 ro

Rossini, G.A. 90

Rousseau, H.J.F. (le

Douanier) 186
Rousseau, J.-J. 32, 38, 56, 6I

Rümke, H.C. 267

Rushdie, S. 243

Ruskin, J. 99, 161, I69

Sainte-Beuve, Ch.A. 80

Saint-Pierre, Ch.I.C., Abbé de 23

Saint-Simon, C.H. de $38,69,80$ Sartre, J.-P. 247

Scherer, W. 75

Schierbeek, B. $140,141,148,267$

Schlegel, F. 31, 33, 35, 66, 260

Schnaase, C. 76

Schoenmaekers, M.H.J. I59, 272

Schönberg, A. 90-91, 92, 93, 103,104

Schopenhauer, A. 166, 229

Scott, W. 65

Seel, M. 229

Segal, G. $20 \mathrm{I}$

Seurat, G. 97, 158

Severini, G. I 56, I 8 1, I 94

Shakespeare, W. 70, 238, 243

Sierksma, F. $123,127,128$,

I 29-132, $133,135,136,137$, ${ }_{13} 8,142,143,144,145,228$, 268

Sjostakovitsj, D. 222

Skinner, Q. 25-28, 29, 30, 36,

$$
252,253-254
$$

Smith, D. 201

Sontag, S. 105-106, 195, 208, 245

Soto, J.R. 201

Spencer, H. 23, 39, 70, 71-73, 75 , 86

Spinoza 32

Staller, I. 218

Stam, M. 197

Stein, G. 237 
Stella, F. 201, 234

Stendhal 80

Stephen, L. 70

Stockhausen, K. 211

Straten, H, van $121,122,132$, $137,138-139,140,144,147$, 148,150

Stravinsky, I. 89-91, 94, 103, $104,108,264$

Swift, J. $47-48,258$

Symonds, J.A. 75

Taine, H. 69, 75-76

Tassoni, A. 45

Täuber-Arp, S. 197, 274

Tergast, N. 134

Thomas, D. 101

Tienhoven, H.J. van $\mathrm{I}_{44}$

Tietze, H. I I 5, 208

Tirso de Molina 229

Tolstoj, L. 222, 232

Trapman, J. 268

Tsjaikovsky, P.I. 222

Turgot, A.R.C.J. 58

Tylor, E.B. $39,70,74$

Tynjanov, J. 95

Tzara, T. 82

Vantongerloo, G. 274

Vasalis, M. 133

Vasari, G. I5, 42, 233

Velásquez, D. 229

Verhoeven, N. 134

Vestdijk, S. I 23, I 26, I 3 I, 137 ,

$$
\mathrm{I}_{4} 8, \text { i so, } 27 \mathrm{I}
$$

Vico, G. $57-58$

Villiers de l'Isle-Adam,

$$
\text { J.M.M.Ph.A. } 263
$$

Villon, J. 199

Vinkenoog, S. $121,132,138$,

$140,144,147,149,269$
Virgilius 47

Vlugt, L.C. van der 174

Voltaire 32, 56, 175

Vroman, L. 241

Wadman, A. 129,268

Wagner, R. 90, 107, 229

Walsh, W.H. 28

Warren, A. 94-95, is I

Warhol, A. 16,213

Webern, A. 207

Weightman, J. 263

Weijers, I. 267

Wellek, R. 41, 94-95, is 1, 262, 265

Whistler, J. 237

White, H. 28

Wilde, O. 237

Wilders, F. zie F. Sierksma

Willebeek Le Mair, H. 194

Wils, J. I $57,158,170,17$ I-1 72 , 173, 175, I 82, 192, 194, 197,

274

Wilson, E. 82, 263

Wilson Knight, G. Io I

Winckelmann, J.J. 57, 66, 259

Wittgenstein, L. 11, 17, 26, 248

Wölfflin, H. 77, 1 59, 202

Woolf, V. 70

Worringer, W. 159

Wotton, H. $47,4^{8}$

Wright, F.L. I 58, 167, 207, 274 



\section{Summary}

\section{More and More Beautiful. On the Idea of Progress in the Arts}

Although generally assumed that the idea of progress is a typical feature of nineteenth-century thought, it is a notion twentieth-century philosophers still wrestle with constantly. To be sure, present-day philosophers are more sophisticated in the use of historical categories, nevertheless it is evident that the idea of progress continues to be of great interest. This is apparent particularly in the arts. While almost no one seemed willing to believe there could be progress in the arts, the idea itself has been the main conceptual category in the historical avant-garde. The significance of the belief in progress reemerged clearly in postmodernist resistance to such an idea, and in the recent discussions about a 'crisis' in the arts, and even an end-of-art.

When and in what context did these speculations of progress arise? In the first chapter it is argued, that by answering this question, we do not need to go as far back as the ancient Greeks, or the Renaissance. For to do so would betray a naive conceptual realism, i.e., the assumption there is such a thing as an essentially invariable idea which manifests itself, or develops, throughout time. On the other hand, nominalistic views or conceptual 'Historismus' are not very helpful for studying the meaning and use of concepts of progress. A more useful line of approach can be found in the work of Reinhart Koselleck. He describes how during the eighteenth century people developed a sense of 'geschichtliche Zeit' - a new awareness of time without a determined future - where historical categories such as 'progress' acquired a pragmatic meaning.

The second and third chapters outline the meaning and use of 
ideas of progress as they developed in the last three centuries. The starting point for this brief history of ideas is the 'Querelle des Anciens et des Modernes'. This debate, circa I700, concerned the question whether then contemporary writers and artists could compete with the Ancients. The 'Querelle' is of interest to us, first of all, because it abandons absolute criteria of Beauty. Some participants in these discussions were beginning to realise that aesthetic values were partially dependent on the contemporary context. Furthermore, they came to understand history as a linear process, but in a finalistic way. The 'Querelle' had everything to do with the growing regard for phantasy and imagination, a development closely connected with the rise of an autonomous aesthetic domain - the rise of the arts as we know them today.

In the age of Romanticism imagination, creativity and originality became very important. In addition, under the impact of the ubiquitous influence of the French Revolution, an historicist consciousness emerged. The idea of progress in the arts could flourish, but only in the restricted sense of a persisting finalism that itself was the consequence of a prevalent Hegelianism. However, in the second half of the nineteenth century with the success of positivism, evolutionism and many new branches of cultural history - an extensive and general belief in steady progress in all realms of reality began to prevail, the arts included. Beginning with modernism, and even more so since the rise of the historical avant-garde, the arts present themselves more and more in the form of movements, inventing the socalled-isms, and perceiving every innovation as a revolution.

The second part of the book deals with the questions: How are concepts of progress used in the arts? And, why have these concepts had a grip on the arts for such a long time? Chapter four analyses the revolutionary vocabulary and the historicist assumptions implied by this vocabulary. It applies Thomas Kuhn's model of scientific development to the arts in so far as this model - as it focusses on the external circumstances accompanying sudden changes in standards and values - will help us explain the use of concepts of progress as well as the desire for 
periodization. Using this model it can be shown how changes are interpreted in terms of progress and conceived of as good, necessary and understandable.

The analysis is supported by the empirical evidence of two case studies. Chapter five describes an important innovation in Dutch poetry, embodied in the 'Beweging van Vijftig' (The Movement of 'so). This chapter deals with the way the Vifftigers engineered a breakthrough with - and through the medium of the magazine Podium. The first ten volumes are examined focussing on the questions: To what extent is the vocabulary of progress used?; What are the effects?; And, in what manner has it been possible for later historians of literature to speak of a kind of progress in retrospect? The sixth chapter concerning itself with the movement 'De Stijl' is a similar study of a magazine, viz., all volumes of De Stijl (1917-1931). This particular case study deals with innovations in architecture and painting. Special attention is paid to the theoretical opinions of the movement's protagonists (among others, Mondriaan and Van Doesburg) about progress, evolution and development.

The last part of the book takes up the problems sketched at the end of chapters three and four, that is, the collapse of the avant-garde, and a feeling of acceleration of history, leading to confusion. This section discusses the present-day meaning and significance of ideas of progress in the arts. Chapter seven deals with the contemporary view that art has come to an end. It criticises the position of the philosopher and art critic Arthur Danto, who denies the possibility of any further historical advance in the (plastic) arts. Though his analysis of the growing importance of conceptual art has merit, his Hegelian interpretation of present-day art as a conceptual culmination and terminus is much too narrow. But even if one rejects Danto's apocalyptic proclamation there still remain sound arguments against the possibility of progress in the arts. However, in the final chapter it is argued that to conceive of art in terms of progress continues to be an idea that makes sense.

The argument in favour of this idea can be summarized as follows. First, by invention and change there is a growth in the 
number of styles, genres, processes, skills, and works of art themselves, which (contrary to achievements in science) will never be completely replaced by new styles, genres, processes, skills and works of art. This quantitative artistic progress also implies a mutual enrichment of works of art by their interaction. Secondly - and this seems more important - the idea of progress in the arts makes sense in terms of cognitive development. In concert with Nelson Goodman's cognitive understanding of the arts, it can be shown that the arts offer us new experiences and points of view, as well as new sensual, emotional and intellectual schemes to interpret reality.

Such a belief in artistic progress, albeit modest and limited, can counter the insipid relativism of a postmodern and posthistorical mentality that until now has proven to be unfruitful in the creation and interpretation of works of art. 


\section{Curriculum vitae}

Maarten Doorman werd op 9 juni 1957 te Meppel geboren. Hij volgde voorbereidend wetenschappelijk onderwijs aan het Baarnsch Lyceum te Baarn (1969-1976) en studeerde van 1977 tot 1984 filosofie aan de Universiteit van Amsterdam, waar hij cum laude afstudeerde op het pessimisme van Schopenhauer. Sinds 1986 is hij als universitair docent verbonden aan de vakgroep wijsbegeerte van de Faculteit der Cultuurwetenschappen (voorheen Faculteit der Algemene Wetenschappen) van de Rijksuniversiteit Limburg. Verder publiceerde Doorman sinds 1985 drie dichtbundels, een bundel dierverhalen en Denkers in de ring. Filosofische polemiek uit as eeuwen (met Willem Visser). Hij recenseert poëzie voor de Volkskrant en is medewerker filosofie van NRC Handelsblad. 


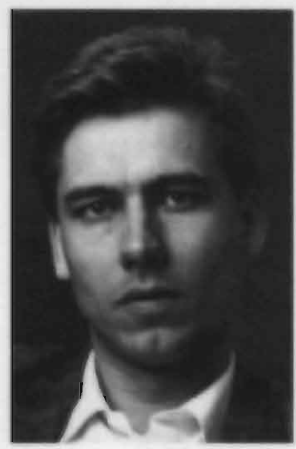

Kunst dient van deze tijd te zijn, anders is ze verouderd. Of liever nog: kunst dient haar tijd vooruit te zijn. Die vooruitgangsgedachte heeft lang in de kunst en in de kritiek geregeerd. In Steeds moover beschrijft Maarten Doorman hoe zulke vooruitgangsideeen in de achttiende eeuw opkwamen en tot en met de avantgarde gemeengoed bleven.

Dit onderzoek naar vooruitgangsideeẽn in de kunst opent een soms verrassend verschiet op de recente geschiedenis van de verschillende kunsten. Steeds mooier verklaart waarom kunstenaar, criticus en kunstwetenschapper zich zo lang van dergelijke vooruitgangsretoriek bleven bedienen. Ter illustratie krijgen de plotselinge opkomst van de Beweging van Vijftig en de roerige geschiedenis van De Stijl uitvoerig de aandacht.

Kan met het postmodernisme en na het afscheid van het vooruitgangsoptimisme ook dit vooruitgangsidee in het museum worden bijgezet? Volgens Maarten Doorman is het idee niet in elk opzicht verouderd. In Steeds mooier pleit de auteur voor een herwaardering van vooruitgangsbegrippen met de bedoeling de als zorgeloosheid vermomde vrijblijvendheid van het postmodernisme te keren.

Maarten Doorman (1957) is filosoof, dichter en essayist.

ISBN 90-351-1352-7

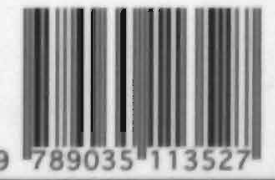

